\title{
MISSÕES JESUÍTICAS COMO SISTEMA
}

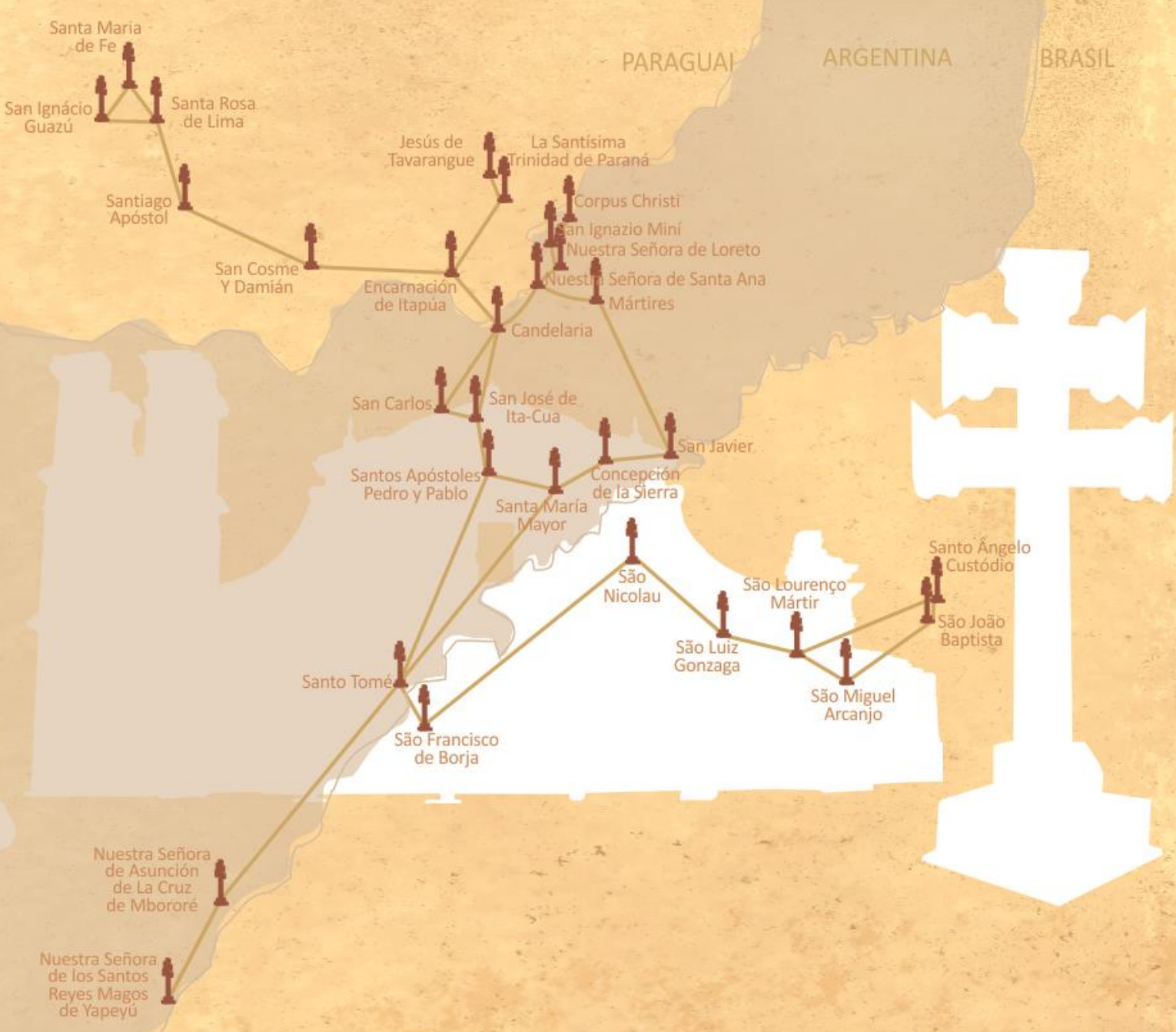

Sandra Schmitt Soster

Instituto de Arquitetura e Urbanismo

Universidade de São Paulo

São Carlos_ 2014 



\title{
Sandra Schmitt Soster
}

\section{MISSÕES JESUÍTICAS COMO SISTEMA}

\author{
Dissertação apresentada ao Programa de Pós- \\ Graduação em Arquitetura e Urbanismo, do Instituto \\ de Arquitetura e Urbanismo da Universidade de São \\ Paulo, como parte dos requisitos necessários para a \\ obtenção do título de mestre em Arquitetura e \\ Urbanismo. \\ Orientadora Profa. Dra. Anja Pratschke \\ Linha de Pesquisa Teoria e História da Arquitetura e do Urbanismo
}

São Carlos-SP

2014 
AUTORIZO A REPRODUÇÃO TOTAL OU PARCIAL DESTE TRABALHO,

POR QUALQUER MEIO CONVENCIONAL OU ELETRÔNICO, PARA FINS

DE ESTUDO E PESQUISA, DESDE QUE CITADA A FONTE.

Soster, Sandra Schmitt

S716m Missões Jesuíticas como Sistema / Sandra Schmitt Soster; orientadora Anja Pratschke. São Carlos, 2014.

Dissertação (Mestrado) - Programa de Pós-Graduação em Arquitetura e Urbanismo e Área de Concentração em Teoria e História da Arquitetura e do Urbanismo -- Instituto de Arquitetura e Urbanismo da Universidade de São Paulo, 2014.

1. Missões Jesuíticas. 2. Tecnologias de Informação e Comunicação. 3. Patrimônio cultural. 4. Pensamento Complexo. 5. Teoria de Sistemas. 6. Educação patrimonial. I. Título. 
FOLHA DE JULGAMENTO

Candidata: Arquiteta e Urbanista Sandra Schmitt Soster

Título da dissertação: "Missões Jesuíticas como Sistema".

Data da defesa: 24/04/2014.

Comissão Julgadora:

Profa. Dra. Anja Pratschke (orientadora) (Instituto de Arquitetura e Urbanismo - USP)

Profa. Dra. Maria Angela P. C. S. Bortolucci (Instituto de Arquitetura e Urbanismo - USP)

Prof. Dr. Luiz Antonio Bolcato Custodio (Centro Universitário Ritter dos Reis - UniRitter)
Resultado:

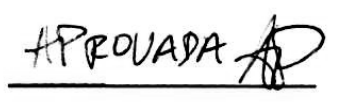

APROUABA H.

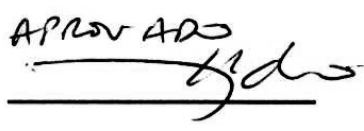

Presidente e Coordenador do Programa de Pós-Graduação em Arquitetura Urbanismo: Professor Associado Márcio Minto Fabricio 

Agradeço a Profa. Dra. Anja Pratschke

por exercer de forma tão maravilhosa sua função de timoneiro em meio ao mar revolto de minhas inúmeras inquietações de pesquisa.

Agradeço às professoras Luzia Sigoli Fernandes Costa e Maria Ângela Pereira de Castro e Silva Bortolucci e ao professor Luiz Antônio Bolcato Custódio por participarem das bancas de avaliação deste trabalho e por toda a contribuição para esta pesquisa e para minha formação como pesquisadora e amante do patrimônio durante estes últimos anos.

Agradeço à FAPESP pelo apoio financeiro fundamental para a realização desta pesquisa.

Agradeço a Vladimir Stello e Matilde Jaramillo por inspirarem minha paixão pelo patrimônio missioneiro através de seu trabalho fabuloso junto ao sítio histórico de São Miguel.

Agradeço a Candice Ballester e Sandra Petry / IPHAN, Myriam M. Ayala / Sub-Secretaría de Gestión Estratégica-Misiones,

Edgar Paredes e Jazmin Amazona / SENATUR, profissionais ligados à preservação das Missões, pelas informações essenciais a esta pesquisa e, em especial, pela hospitalidade.

Agradeço ao Prof. Dr. Juan Luís Suárez / The Cultureplex Lab pela disponibilidade e gentileza em seus e-mails.

Agradeço a Cynthia Nojimoto, Luciana Roça, Mayara Dias e Priscilla Marchetto, colegas de pesquisa e amigas. 


\section{ABSTRACT}

Taking as a study case the old set called Thirty Missions of the Guarani, which comprises part of the territories of Brazil, Argentina, Paraguay and Uruguay, this research believes that a look based on complex thinking is necessary to observe it as a historical-typological system and to understand the relevance of what may be called missionary heritage preservation system, which involves tangible and intangible heritage of this unique culture and also the performed interactions between several agents involved in its preservation: researchers, responsible agencies, tourism guides and community. Given the current communicational and technological scenery of the 21st century, this research seeks theoretical foundation to emphasize the need to create and implement digital tools that not only help registry, preservation and diffusion of this heritage, but also potentiate the interactions between the agents involved, so the system can work more efficiently and stay alive, fulfilling its social function as support for memory and identity of a local culture and a glocal social reflection 
Tendo como estudo de caso o antigo conjunto denominado Trinta Povos das Missões, que compreende parte dos territórios do Brasil, Argentina, Paraguai e Uruguai, esta pesquisa entende que é necessário um olhar baseado no pensamento complexo para observá-lo como um sistema histórico-tipológico e para entender a atualidade do que se pode chamar sistema de preservação do patrimônio missioneiro, que envolve o patrimônio material e imaterial desta cultura ímpar e também as interações realizadas entre os diversos agentes envolvidos em sua preservação: pesquisadores, órgãos responsáveis, guias de turismo e comunidade. Diante do cenário comunicacional e tecnológico do século XXI, a pesquisa busca embasamento teórico para enfatizar a necessidade de criação e implementação de ferramentas digitais que auxiliem não somente registro, preservação e divulgação deste patrimônio, mas também potencializem as interações entre os agentes envolvidos, para que o sistema funcione de maneira mais eficiente e mantenha-se vivo, cumprindo sua função social como suporte da memória e da identidade de uma cultura local e de uma reflexão social glocal. 

INTRODUÇÃO 1

CAPÍTULO 1_ AS MISSÕES JESUÍTICAS COMO SISTEMA COMPLEXO. 19

1.1 Da ascensão à expulsão: história missioneira 21

1.20 conjunto e a unidade: Urbanismo e Arquitetura.. 40

1.3 Conversação entre duas culturas: Arte e Sociedade. 61

1.4 Complexidade missioneira no passado 73 CAPÍTULO 2_PRESERVAR COMO SISTEMA.

2.1 Patrimônio missioneiro .83

2.2 Patrimônio integrado .104

2.3 Agentes nacionais e interações. 119

2.4 Complexidade da preservação do patrimônio missioneiro143 CAPÍTULO 3_COMO MANTER UM SISTEMA VIVO

3.1 Território, mapa e experiência 153

3.2 Panorama online das Missões. 170

3.3 Estudo de Casos: Tendências 183

3.4 Mídias em prol da complexidade do patrimônio 209 CONSIDERAÇÕES FINAIS

REFERÊNCIAS BIBLIOGRÁFICAS

LISTA DE FIGURAS

LISTA DE TABELAS 



\section{INTRODUÇÃO}

"[...] esta história, sendo história portuguesa, não é a história de Portugal, sendo história brasileira, não é a história do Brasil, sendo história eclesiástica, não é a história da Igreja. [...]"

(LEITE, 1938, p. XI). 
Imagem da página anterior: São Miguel - Brasil (CHAROLA; MAGADÁN, 2009, p. 11). 
O objeto de estudo da dissertação é a antiga Província Jesuítica do Paraguai, que compreendia Trinta Missões Jesuíticas, localizadas nos atuais territórios de três países: Argentina, Brasil e Paraguai. Devido à grandeza do patrimônio dos Trinta Povos ${ }^{1}$, foram selecionados três sítios históricos a serem trabalhados: São Miguel Arcanjo - Brasil, San Ignácio Miní - Argentina, e Santísima Trinidad del Paraná - Paraguai ${ }^{2}$. Por serem os mais bem conservados, pressupõe-se que sejam alvos mais frequentes da ação dos órgãos responsáveis, ou seja, que sejam os mais "completos" em termos de conteúdo e ações. Servem como exemplos para entender como cada país trata as suas Missões em relação aos chamados pilares museológicos, mencionados pelo museólogo norte-americano Garry Thomson (1995 [1978]): pesquisa, preservação e divulgação. Neste contexto, é analisada também a dimensão humana dos sistemas que cada um destes pilares desenvolve: os atores envolvidos nos processos configurados por estes pilares e as ligações destes atores com os demais elementos que os rodeiam e permeiam.

\section{Objetivo}

O objetivo principal desta pesquisa é reafirmar a necessidade de estudar, preservar e divulgar as Missões Jesuíticas de maneira integrada, validar seu entendimento como um sistema

\footnotetext{
${ }^{1}$ De acordo com Candice Ballester (2010), responsável pelo escritório técnico do IPHAN em São Miguel à época da entrevista, seria "um trabalho para a vida inteira".

${ }^{2}$ Embora nesta pesquisa sejam analisadas apenas três missões (a melhor conservada de cada país), cabe ressaltar que os sítios mais modestos também merecem ser valorizados pela importância de seu testemunho como peças essenciais para o melhor entendimento desta experiência histórica que marcou a formação cultural da região onde ocorreu.
} 
complexo e propor possibilidades para realizar ações de preservação através de meios digitais. Neste contexto, são objetivos específicos: 1. Entender as Missões Jesuíticas como um sistema; 2. Entender a preservação do patrimônio missioneiro como um sistema, analisando seus principais agentes, as interações entre eles e deles com o patrimônio; 3. Coletar e sistematizar dados sobre patrimônio histórico e mídia digital; 4. Levantar e estudar o patrimônio missioneiro disponível em âmbito virtual; e 5. Apresentar ferramentas digitais que demonstrem a possibilidade de um olhar sobre a preservação patrimonial voltado ao seu tratamento como um sistema, potencializando a pesquisa, a preservação e a divulgação do patrimônio e incentivando a apropriação cultural por parte da comunidade local e mundial.

É importante salientar que estes objetivos vêm ao encontro das indicações realizadas ao final do "Programa de Capacitação para Conservação, Gestão e Desenvolvimento Sustentável das Missões Jesuíticas dos Guarani", evento promovido pela UNESCO, que reuniu representantes dos órgãos nacionais protetores das Missões Jesuíticas no período de 2000 a 2003. Dentre os objetivos apontados pelo programa, destacam-se os seguintes:

Trabalhar de forma interativa nos diferentes sítios e países. [...]

Fortalecer as relações entre o patrimônio e a comunidade. [...]

Reconstruir o espaço comum, construir uma visão integradora. [...]

Criar mecanismos de articulação em âmbito regional por meio do Mercosul. [...]

Comunicar uma mensagem global (do sistema) e mensagens específicas (de cada sítio). [...]

[Promover a conclusão de que] São sítios complementares e não competitivos, onde cada um tem suas características e atrativos particulares que devem ser potencializados. [...]

Elaborar um plano integrado de desenvolvimento turístico-cultural para cada um dos sítios escolhidos [...] 
[...] Integrar com uma leitura histórico-cultural os períodos: guarani, pósjesuítico e colonial, até hoje, criando uma consciência de continuidade. [...]

Centralizar a documentação dispersa, em busca de uma informação integrada. [...]

Unificar critérios de apresentação dos sítios para dar ideia de sistema integrado e facilitar a compreensão dos monumentos. [...]

Sensibilizar as comunidades e visitantes. [...]

Promover a apropriação do processo Jesuítico-Guarani e de suas evidências materiais e imateriais, enquanto raízes culturais. [...] (BARBACCl; GREMENTIERI, 2004a, p. 29-34)

\section{Premissa da pesquisa}

É premissa dessa pesquisa que as ações de pesquisa, preservação e divulgação, atualmente realizadas em âmbito nacional, podem ser potencializadas se as Missões Jesuíticas forem entendidas como um sistema complexo e tais trabalhos forem realizados internacionalmente, integrando os países onde se localizam e os agentes desse sistema, como confirmado por atividades realizadas por representantes dos países envolvidos, que ocorreram na década de 1990. Neste sentido, esta pesquisa reúne elementos para discutir o papel de interfaces colaborativas online na preservação do patrimônio cultural e em sua apropriação pela sociedade, de modo que sejam utilizadas como recurso aprimorado de preservação e conscientização patrimonial e como ferramenta de disseminação, intercâmbio e construção coletiva de conhecimento sobre o tema. 


\section{Metodologia}

Em busca da concretização desta pesquisa, foram realizados trabalhos de coleta e sistematização de referências bibliográficas e de exemplos de aplicações das mídias digitais para a preservação do patrimônio. Foram realizadas entrevistas presenciais e por e-mail sobre: 1. o estado atual dos sítios históricos; 2. o patrimônio material e imaterial existente; e 3. a atuação dos órgãos responsáveis. Também foram levantadas e estudadas interfaces online existentes sobre as três Reduções jesuítico-guarani escolhidas, como fontes de informações sobre o objeto de estudo e como material para discussão sobre o estado atual da preservação deste importante patrimônio histórico da humanidade. Com o intuito de analisar as atuais possibilidades em termos de sistemas digitais para o registro, a organização, a preservação e a divulgação do patrimônio histórico, foram observadas tecnologias e metodologias que são utilizadas para a preservação e divulgação do patrimônio histórico. Esta última etapa proporcionou embasamento para a definição de diretrizes para incentivar a apropriação do bem cultural por parte da comunidade através da utilização de tecnologias de comunicação e informação atuais, com a finalidade de possibilitar maior visualização e entendimento do patrimônio reconhecido internacionalmente constituído pelo conjunto dos Trinta Povos das Missões.

\section{Estrutura geral}

O raciocínio desenvolvido ao longo do trabalho apresenta possibilidades para uma abordagem do patrimônio missioneiro sob um olhar complexo, entendendo o patrimônio em seu 
passado e presente. Esta reflexão direciona a pesquisa à proposição do uso de mídias digitais com o intuito de que os sítios históricos da antiga Província Jesuítica do Paraguai e todas as informações sobre o assunto sejam trabalhados de forma unificada, inclusive sem os limites de fronteiras nacionais (que atualmente definem sua preservação, conforme especificado pela Carta de Atenas, de 1931) e com a possibilidade de intercâmbio de conhecimento entre os agentes envolvidos. De modo que se ofereçam ideias para que se configure uma rede de conhecimento e memória que possa promover experiência e entendimento diferenciados deste patrimônio.

\section{Capítulo 1_As Missões Jesuíticas como sistema}

Neste primeiro capítulo, é apresentada a experiência histórica das Missões Jesuíticas da antiga Província do Paraguai, no período que compreende a chegada da Companhia de Jesus ao Brasil, a implantação das Reduções Jesuíticas (1549), a expulsão dos jesuítas e a guerra ocasionada por esta decisão da Coroa Espanhola (1750). Neste contexto, as Missões Jesuíticas são analisadas como o conjunto que constituíram, de modo a frisar sua complementariedade, pois se entende que tal recorte é fundamental para um entendimento integrado deste patrimônio histórico. Como enfatiza Maurice Zago (1997, p. 13, tradução nossa ${ }^{3}$ ), editor do livro “As Missões Jesuíticas dos Guarani" ": "Hoje em dia, o mundo como um todo é parte do nosso patrimônio, além das fronteiras de uma vizinhança, de um país e mesmo de um continente". De acordo com o arqueólogo peruano Elias Mujica (2004a, p. 27), é indicado considerar o conjunto das Missões

\footnotetext{
${ }^{3}$ Do original em inglês: "The world nowadays is entirely part of our heritage, beyond the boundaries of a neighbourhood, a country and even a continent" (ZAGO, 1997, p. 13).

${ }^{4}$ Do original em inglês: The Jesuit missions of the Guaranis.
} 
"como um sistema patrimonial integrado, que tenha como referência constante a rede original dos Trinta Povos e toda a infraestrutura de comunicação e produção espalhada no território que ocuparam".

Este capítulo pretende enfatizar a necessidade de analisar e entender as Missões Jesuíticas como o conjunto que constituíram no passado, uma rede de povoados marcada por profundas relações políticas e econômicas e embasada em uma doutrina comum: a evangelização pela Companhia de Jesus. Os relacionamentos e processos ocorridos entre o todo e suas partes demonstram que não há sentido em examiná-los separadamente. A construção desse panorama das Missões Jesuíticas como um sistema complexo tem o objetivo de prover embasamento conceitual para a discussão que ocorrerá ao longo dos demais capítulos.

Portanto, acredita-se que é necessário retomar o sentido de rede que fez com que o conjunto fosse chamado de Os Trinta Povos das Missões. E isto se daria através da unificação da preservação de todo o patrimônio missioneiro, de modo que a divulgação das Missões como conjunto fosse um caminho para seu fortalecimento como importante patrimônio único da Humanidade, assim como foi a experiência nelas desenvolvida pelos jesuítas.

\section{Capítulo 2_Preservar como sistema}

A partir de informações obtidas nas visitas técnicas realizadas em Janeiro de 2013 aos três sítios históricos selecionados, São Miguel - Brasil, Trinidad - Paraguai e San Ignácio Miní Argentina, este segundo capítulo analisa as ações realizadas após um extenso período de hibernação, entre a expulsão dos jesuítas em 1750, quando foram abandonadas, e a redescoberta das ruínas dois séculos depois. Pretende-se entender como ocorrem as interações entre os 
elementos físicos, imateriais e humanos no interior do que este trabalho denomina sistema de preservação do patrimônio missioneiro, com especial atenção às atividades de pesquisa, preservação e divulgação segundo as políticas preservacionistas nacionais em vigência nos respectivos países.

Neste sistema, a preservação e a percepção das Missões estão atreladas a diversos elementos, que podem ser divididos em duas categorias: 1. Patrimônio e 2. Agentes e suas interações. A primeira categoria, tratada no segundo item deste capítulo, diz respeito ao “conjunto patrimonial das Missões Jesuíticas dos Guarani [que] é constituído por uma série de bens culturais imóveis, móveis, materiais e imateriais de grande significado histórico e cultural para cidades, estados e países onde se localizem" (BARBACCI; GREMENTIERI, 2004b, p. 19). O patrimônio material é constituído por todo o acervo físico, que inclui as ruínas das edificações e outros elementos distribuídos pelos sítios históricos (patrimônio imóvel) e obras de arte conservadas no interior de espaços museológicos, principalmente estatuária e instrumentos musicais (patrimônio móvel). Por um lado, o patrimônio imaterial se refere a toda a cultura e a história que permeiam tais objetos e são fruto das relações desenvolvidas durante a atuação da Companhia de Jesus neste território do chamado Novo Mundo. Enquanto isso, a segunda categoria, denominada agentes e suas interações, é tratada no terceiro item deste capítulo e envolve órgãos responsáveis, pesquisadores, comunidade e guias de turismo; e as ações já realizadas em relação ao patrimônio missioneiro e aquelas que podem ser vislumbradas a partir de um olhar embasado no pensamento sistêmico.

Esta análise tem a finalidade de enfatizar a necessidade de uma preservação integrada de todos os tipos de bens patrimoniais e que envolva ações relacionadas a todos os agentes 
envolvidos para o pleno funcionamento deste sistema, de modo a justificar a permanência deste patrimônio através do maior estímulo à apropriação pela comunidade local e internacional.

\section{Capítulo 3_Como manter um sistema vivo}

Este capítulo refere-se ao pilar museológico da divulgação do patrimônio e nele é discutida a representação do patrimônio em meio virtual, suas consequências e potencialidades. É realizada uma discussão sobre o uso de tecnologias de informação e comunicação para organizar e colocar em evidência questões, necessidades e ações relacionadas à preservação das Missões Jesuíticas como um sistema vivo, entendido como aquele em que as interações entre os agentes e destes com o patrimônio é realizada de modo efetivo, justificando a relevância da preservação em um contexto glocal ${ }^{5}$. Apresenta-se também uma análise da utilização de plataformas digitais para o registro do patrimônio, a preservação e a educação no âmbito dos órgãos de preservação das Missões Jesuíticas, com a finalidade de se entender o estado atual da divulgação online, suas principais características e seus pontos positivos e negativos.

Ao final deste capítulo, é lançado um olhar para fora do contexto das Missões a fim de buscar possíveis ferramentas digitais para o tratamento do patrimônio de maneira integrada, propondo outra abordagem possível para os sítios históricos missioneiros, que poderia atuar como

uma base de dados integradora de vários centros, patrimônios arquitetônicos e museus. Buscando manter vivas as dinâmicas culturais da comunidade, a

\footnotetext{
${ }^{5} \mathrm{O}$ termo glocal se refere à atual justaposição espacial e temporal das esferas local e global, propiciada pelos meios de cominação em termo real, onde o indivíduo se encontra simultaneamente em um espaço local (seu contexto físico e cultural) e global (a visão do mundo). Para saber mais, ver VIRILIO, Paul. O espaço crítico. Rio de Janeiro: Ed. 34,1993 e TRIVINHO, Eugênio. Glocal: para a renovação da crítica da civilização mediática. In: FRAGOSO, Suely; FRAGA DA SILVA, Dinorá (Org.). Comunicação na cibercultura. São Leopoldo: Unisinos, 2001.
} 
preservação e o acesso físico e virtual a tais patrimônios, contribuem para a valorização das culturas tradicionais, e reforçam o sentimento de pertencimento e de identidade, garantindo consequentemente a permanência desse patrimônio para as futuras gerações (PRATSCHKE; SANTIAGO, 2006, p. 1).

O propósito final desta análise é aprimorar a preservação do patrimônio missioneiro através da indicação de uma abordagem para as ações necessárias pontuada pelo intermédio da organização das informações e da comunicação a partir de plataformas digitais. Entende-se que as mídias digitais podem auxiliar a comunicação entre todos os agentes, promovendo e possibilitando suas interações tão essenciais para a preservação do patrimônio, integrando e fazendo interagir história, memória e patrimônio através do patrimônio material e imaterial e do conhecimento reunido pelos agentes envolvidos: comunidade, órgãos responsáveis, guias de turismo e pesquisadores.

\section{Principais referências teóricas}

De acordo com o matemático e filósofo polonês Alfred Tarski, "nenhum sistema dispõe de meios suficientes para se auto-explicar a si próprio" (TARSKI apud MORIN; LE MOIGNE, 2000, p. 200). Desse modo, é necessário o uso de metodologias para entendê-lo. Durante muito tempo, a ciência baseou-se no Reducionismo, que acredita que o todo é igual à soma das suas partes e posiciona o pesquisador como uma entidade externa que não causa interferência no sistema.

Segundo o biólogo austríaco Karl Ludwig von Bertalanffy (1995 [1987], p. 130), o Reducionismo acreditava que "a biologia, as ciências sociais e do comportamento deviam ser 
tratadas de acordo com o paradigma da física e finalmente reduzidas a conceitos de entidades de nível físico". Embora seja um método de investigação importante no meio acadêmico, ele se mostrou incapaz de explicar de forma completa fenômenos complexos como os seres vivos e a sociedade, pois nestes casos, de acordo com os biólogos chilenos Humberto Maturana e Francisco Varela (1995 [1987], p. 36),

[...] O que as propriedades dos componentes fazem é só especificar o espaço particular em que tal sistema existirá, mas as propriedades dos componentes não determinam por si sós a organização de um sistema nem tampouco as propriedades do sistema como conjunto.

O olhar investigativo voltou-se a estes sistemas que não podem ser explicados por um método reducionista: aqueles que apresentam uma capacidade de produção de si mesmos através da relação entre seus componentes, de tal forma que sua definição vai além da soma de suas partes. Além disso, as teorias sistêmicas passaram a entender o observador como parte integrante do sistema, como um elemento que exerce influência sobre ele.

Neste contexto, o pensamento complexo foi formulado em 1970 pelo antropólogo, sociólogo e filósofo francês Edgar Morin (2005 [1970] ${ }^{6}$ ). Para entender este pensamento, seguem as palavras do próprio autor:

Imaginemos uma tapeçaria contemporânea. Ela comporta fios de linho, seda, algodão, lã, de cores variadas. Para conhecê-la, seria interessante conhecer as leis e princípios relativos a cada uma dessas espécies de fio. Contudo, a soma dos conhecimentos sobre cada tipo de fio que compõe a tapeçaria é insuficiente para conhecer essa nova realidade que é o tecido (ou seja, as qualidades e propriedades dessa tessitura). É também incapaz de nos auxiliar no conhecimento da sua forma e configuração.

\footnotetext{
${ }^{6}$ Quando forem citados dois anos de uma mesma publicação, o primeiro refere-se ao ano da versão consultada e aquele que se encontra entre colchetes é o ano da primeira publicação.
} 
A primeira etapa da complexidade indica que conhecimentos simples não ajudam a conhecer as propriedades do conjunto. Trata-se de uma constatação banal, que no entanto tem consequências não banais: a tapeçaria é mais do que a soma dos fios que a constituem. $O$ todo é mais do que a soma de suas partes.

A segunda etapa da complexidade revela que o fato de existir uma tapeçaria faz com que as qualidades desse ou daquele fio não possam, todas elas, expressarse na plenitude, pois estão inibidas ou virtualizadas. Assim, o todo é menor do que a soma de suas partes.

A terceira etapa da complexidade é a mais difícil de entender pela nossa estrutura mental. Ela diz que o todo é ao mesmo tempo maior e menor do que a soma de suas partes.

Na tapeçaria, como nas organizações, os fios não estão dispostos ao acaso. Estão organizados em função da talagarça, isto é, de uma unidade sintética na qual cada parte contribui para o conjunto. A tapeçaria é um fenómeno que pode ser percebido e conhecido, mas não pode ser explicado por nenhuma lei simples (MORIN, 1986 apud NASCIMENTO, 2008, p. xxxi).

Esta metodologia é utilizada em várias áreas e envolve diversos conceitos e estratégias de interação, dentre os quais serão utilizados os apresentados a seguir.

\section{Sistema}

A palavra sistema deriva do grego sietemiun, que designa um conjunto cujos elementos são interconectados e formam um todo organizado. O pensamento complexo afirma que ele é marcado não somente pelos elementos que o compõem, mas também pela interação entre eles. Desse modo, o sistema se configura como "um conjunto de objetos entendidos como uma totalidade de eventos, pessoas ou ideias que interagem uns com os outros" (SERRA, 2006, p. 70). Além disso, é composto de processos, que podem ser entendidos como "o modo como se sucedem os estados diferentes do sistema no tempo" (SERRA, 2006, p. 72). Segundo o 
ciberneticista belga Francis Heylighen (2008, p. 4, tradução nossa ${ }^{7}$ ), "Os componentes de um sistema complexo são comumente modelados como agentes, ou seja, sistemas individuais que atuam sobre seu ambiente em resposta aos eventos que experienciam. Exemplos de agentes são pessoas, firmas, animais, células e moléculas".

É relevante para esta pesquisa o conceito de sistemas abertos ou sistemas vivos, cujos elementos internos estão sempre em interação, em busca do equilíbrio devido à constante troca de informações com o ambiente. Dessa forma, algumas de suas propriedades só se manifestam e são identificáveis quando seus elementos estão em conjunto. O que frisa a importância de analisar também os contextos em que os sistemas se inserem, pois os fatores externos influenciam as interações realizadas por eles.

Nesta pesquisa, entende-se que existe a necessidade de perceber e incentivar as relações que os elementos físicos e humanos envolvidos na preservação das Missões Jesuíticas mantêm entre si. O que significa repensar o enfoque atual em dois aspectos: 1 . em relação aos vestígios materiais e imateriais, que são tratados como objetos isolados ou pequenos grupos, em parte pelas fronteiras geográficas e políticas que os separam; e 2. em relação às interações entre os agentes envolvidos na preservação (pesquisadores, órgãos responsáveis, guias de turismo e comunidade), que são escassas e devem ser potencializadas para o pleno funcionamento deste sistema. Diante da análise deste sistema sob este aspecto das interações da ordem da troca de informações e da comunicação, esta pesquisa entende que é preciso criar e implementar ferramentas que auxiliem estas interações e, desse modo, justifiquem a permanência deste

\footnotetext{
${ }^{7}$ Do original em inglês: "The components of a complex system are most commonly modeled as agents, i.e. individual systems that act upon their environment in response to the events they experience. Examples of agents are people, firms, animals, cells and molecules. [...]" (HEYLIGHEN, 2008, p. 4).
} 
patrimônio. Isto porque, enquanto as interações entre os agentes só ocorrem pela existência do patrimônio, este também só é importante se a comunidade como um todo perceber sua importância.

\section{Auto-Organização}

O conceito de auto-organização foi proposto pelo ciberneticista inglês W. Ross Ashby (2004 [1962]) no contexto das máquinas. Segundo Heylighen (2008, p. 6, tradução nossa $\left.{ }^{8}\right)$,

A auto-organização pode ser definida como a emergência espontânea de uma estrutura global através de interações locais. "Espontânea" significa que nenhum agente interno ou externo está no controle do processo [...]. O processo é verdadeiramente coletivo, ou seja, paralelo e distribuído ao longo de todos os agentes. [...]

Ele ainda afirma que os

Processos de auto-organização literalmente criam ordem a partir da desordem. Eles são responsáveis pela maioria dos padrões, estruturas e arranjos ordenados que encontramos no mundo natural, e muitos daqueles dos reinos da mente, da sociedade e da cultura. [...] (HEYLIGHEN, 2008, p. 2, tradução nossa ${ }^{9}$ )

${ }^{8}$ Do original em inglês: "Self-organization can be defined as the spontaneous emergence of global structure out of local interactions. 'Spontaneous' means that no internal or external agent is in control of the process [...]. The process is truly collective, i.e. parallel and distributed over all the agents. [...]" (HEYLIGHEN, 2008, p. 6).

${ }^{9}$ Do original em inglês: “Processes of self-organization literally create order out of disorder. They are responsible for most of the patterns, structures and orderly arrangements that we find in the natural world, and many of those in the realms of mind, society and culture. [...]" (HEYLIGHEN, 2008, p. 2). 
Segundo ele, estruturas formadas através deste processo têm caráter de rede e são adaptativas. Ou seja, os agentes interagem entre si de modo a formar uma cadeia de interações, que permitem a estruturação deste sistema e sua sobrevivência diante de perturbações internas e externas.

Nesta pesquisa, entende-se que no passado a relação entre jesuíticas e indígenas teve um forte caráter de auto-organização, onde seus elementos e agentes necessitaram adaptar-se mutuamente a cultura diferente que se colocou ao seu lado durante este processo. Também se utiliza este conceito para analisar como os aspectos físicos e humanos do sistema atual de preservação missioneiro interagem entre si de modo a enfatizar a necessidade de entendê-los em seu caráter de complementariedade. Além disso, é importante para a análise dos meios digitais como ferramentas que poderiam auxiliar não somente as atividades museológicas de registro, preservação e divulgação do patrimônio, mas também estas interações necessárias entre os elementos do sistema. Desse modo, entende-se que é possível utilizar recursos no interior deste sistema que medeiem sua auto-organização, de modo a intensificar suas interações e direcionar seus esforços de maneira colaborativa.

\section{Emergência}

Segundo Heylighen (2008), a emergência é uma propriedade dos sistemas que está relacionada ao princípio fundamental do pensamento complexo: o todo não pode ser entendido como a soma de suas partes. Nas palavras do autor, "[...] Por exemplo, uma célula tem a propriedade de estar viva, enquanto as moléculas que a constituem não possuem tal propriedade [...]. Em vez das partes individualmente, as propriedades emergentes caracterizam o padrão de 
interações ou relações entre elas. [...]" (HEYLIGHEN, 2008, p. 9, tradução nossa ${ }^{10}$ ). Algumas características de um sistema só ocorrem quando seus elementos e agentes estão reunidos e interagindo entre si.

Nesta pesquisa, este conceito é utilizado para entender o caráter de unicidade da cultura originada pela interação entre jesuítas e indígenas na antiga Província do Paraguai e também para analisar as possibilidades de interações que ocorrem atualmente no sistema de preservação do patrimônio missioneiro.

\section{Observação}

Toma-se emprestado este conceito da Cibernética de Segunda Ordem do cientista austríacoamericano Heinz Von Foerster, segundo a qual o observador do observador concebe apenas uma representação do objeto concreto, marcada por sua subjetividade e pela do primeiro observador. Segundo esta teoria, qualquer tentativa de descrever um sistema é parcial, porque o observador não consegue dar conta do âmago de todos os elementos envolvidos (especialmente se tratando de um conjunto social de indivíduos) e insere na descrição que realizada suas próprias escolhas e visões de mundo.

Essa situação de diluição do objeto, sua fragmentação por influência de visões de mundo, se agrava quando as informações recebidas provêm de fonte autoral, pois esse processo implica em mais um observador dentro do ciclo. O que ocorre no caso das Missões Jesuíticas, pois os

\footnotetext{
${ }^{10}$ Do original em inglês: "[...] For example, a cell has the property of being alive, while the molecules that constitute it lack that property [...]. Rather than the parts individually, emergent properties characterize the pattern of interactions or relations between them. [...]" (HEYLIGHEN, 2008, p. 9).
} 
registros históricos da experiência da Companhia de Jesus são escritos pelos padres e se caracterizam como únicas fontes de obtenção de informações sobre o tema. Portanto, ao analisar os dados históricos contidos no Capítulo 1 desta pesquisa, deve-se levar em consideração que foram produzidos apenas pelos olhos dos padres (pois as tribos envolvidas eram culturas ágrafas) e, portanto, constituem relatos imparciais e subjetivos.

Em outra instância, este conceito de observação deve ser utilizado ao analisar a preservação auxiliada pelos ambientes virtuais. Contudo, esta atividade possui caráter oposto ao anterior, pois possibilita a pesquisa em várias fontes e uma visão esmiuçada dos objetos concretos e também da experiência histórica. Desse modo, é possível reduzir a diluição do objeto e complementar o entendimento do patrimônio através de um conjunto maior de informações, de maneira que concreto e virtual se complementam.

É importante ressaltar que não se pretende aqui esgotar o assunto, nem tão pouco entrar em seus mais profundos questionamentos, pois se acredita que esta seria uma tarefa impossível mesmo para os especialistas nas áreas em questão. A intenção é formular um embasamento teórico que forneça subsídios para a compreensão das Missões Jesuíticas sob o viés do pensamento complexo. 
CAPÍTULO 1

AS MISSÕES JESUÍTICAS COMO SISTEMA COMPLEXO

$O$ povo de cada reduc̃ã constitúa um todo,

formava UM só organism

Era simples fração integrante da coletividade

(Pe. Antonio Sepp, 1980 [1687] p. 14) 
Neste primeiro capítulo, é apresentada a experiência histórica das Missões Jesuíticas da antiga Província do Paraguai, no período que compreende a chegada da Companhia de Jesus ao Brasil, a implantação das Reduções Jesuíticas (1549), a expulsão dos jesuítas e a guerra ocasionada por esta decisão da Coroa Espanhola (1750). Neste contexto, as Missões Jesuíticas são analisadas como o conjunto que constituíram, de modo a frisar sua complementariedade, pois se entende que tal recorte é fundamental para um entendimento integrado deste patrimônio histórico. Como enfatiza Maurice Zago (1997, p. 13, tradução nossa ${ }^{11}$ ), editor do livro "As Missões Jesuíticas dos Guarani ${ }^{12 ”: ~ " H o j e ~ e m ~ d i a, ~ o ~ m u n d o ~ c o m o ~ u m ~}$ todo é parte do nosso patrimônio, além das fronteiras de uma vizinhança, de um país e mesmo de um continente". De acordo com o arqueólogo peruano Elias Mujica (2004a), deve-se considerar o conjunto das Missões como um sistema patrimonial integrado, referindo-se sempre à rede original dos Trinta Povos.

Este capítulo pretende enfatizar a necessidade de analisar e entender as Missões Jesuíticas como o conjunto que constituíram no passado, uma rede de povoados marcada por profundas relações políticas e econômicas e embasada em uma doutrina comum: a evangelização pela Companhia de Jesus. Os relacionamentos e processos ocorridos entre o todo e suas partes demonstram que não há sentido em examiná-los separadamente. A construção desse panorama das Missões Jesuíticas como um sistema complexo tem o objetivo de prover embasamento conceitual para a discussão que ocorrerá ao longo dos demais capítulos.

Portanto, acredita-se que é necessário retomar o sentido de rede que fez com que o conjunto fosse chamado de Os Trinta Povos das Missões. E isto se daria através da unificação da preservação de todo o patrimônio missioneiro, de modo que a divulgação das Missões como conjunto fosse um caminho para seu fortalecimento como importante patrimônio único da Humanidade, assim como foi a experiência nelas desenvolvida pelos jesuítas.

Imagem da página anterior: San Ignácio Miní, Argentina (CHAROLA; MAGADÁN, 2009, p. 7).

${ }^{11}$ Do original em inglês: "The world nowadays is entirely part of our heritage, beyond the boundaries of a neighbourhood, a country and even a continent" (ZAGO, 1997, p. 13).

${ }^{12}$ Do original em inglês: The Jesuit missions of the Guaranis. 
Antes de iniciar-se esta discussão é importante salientar que os habitantes da América précolombiana serão denominados "índios" por ser este o termo comumente utilizado pelo antropólogo brasileiro Darcy Ribeiro (1995) e por falta de um termo melhor. Contudo, este termo constitui um erro histórico que remete à época dos grandes descobrimentos, quando os navegadores imaginaram estar chegando às Índias. Deve-se salientar que, cada tribo possui uma denominação própria e identitária.

Essa ressalva se faz necessária ao trabalharem-se os Trinta Povos ${ }^{13}$, que foram construídos ao longo do período compreendido entre 1609 e 1706. Esta construção histórica é tida como uma experiência política e sociológica magnífica e única no mundo na opinião da maioria dos estudiosos consultados durante essa pesquisa. Os preceitos de sua filosofia se destacaram ao longo da História, segundo o bacharel em Letras Mário Simon (2010, p. 13), por induzirem práticas mais humanitárias do que as dos outros colonizadores espanhóis e portugueses. O que se deve, em parte, por sua origem em um "local de convergência da tradição medieval e dos novos fermentos do Humanismo e do Renascimento", como afirma a psicóloga Marina Massimi (2004, p. 28). E, diante da amplitude territorial e das consequências de sua atuação, a Companhia se

${ }^{13}$ O número de missões fundadas entre os anos de 1609 e 1706 é mais, mas diversas delas não tiveram êxito em sua estruturação e continuidade, ou foram destruídas no século XIX em função das investidas bandeirantes. Portanto, os chamados Trinta Povos das Missões compreendem apenas as Missões Jesuíticas do período final da atuação da Companhia de Jesus. Também cabe salientar que, a denominação "Trinta Povos" é posterior à época missioneira, contudo é comumente utilizada (CUSTÓDIO, 2014). Nos documentos jesuíticos, os termos utilizados eram "Reduções" ou "Doutrinas" para os aldeamentos, e "Povos" para os habitantes (CUSTÓDIO, 2014). Nesta pesquisa, utilizamos os termos "Povos", "Reduções" e "Missões" nos referindo a todos os aspectos físicos e culturais relacionados às missões jesuíticas. 
consagrou como "um dos mais importantes movimentos culturais da Europa na época" (SIMON, 2010, p. 13). De modo que,

Voltaire afirmou que as reduções jesuíticas dos séculos 16, 17 e 18 foram o triunfo da Humanidade. Montesquieu comparou-as ao sistema políticofilosófico imaginado por Platão, em A República. Hegel salientou a evolução humana a partir de uma utopia fundada na fraternidade entre os diferentes (GREENHALGH, 2004, p. 1).

De acordo com os historiadores Michel Parent e Claudia Baeta Leal (2009, p. 152-154), “As reduções indígenas foram materializações aparentemente bem-sucedidas de projetos de sociedades e de cidades utópicas tais como os humanistas do século XVI as haviam concebido, em particular Thomas Moore. [...] [De modo que] foi vivida uma 'utopia' bem real e aparentemente bem-sucedida e fraterna".

A Companhia de Jesus foi fundada em 1534 pelo militar e religioso basco Inácio de Loyola [1491-1556] e reconhecida pelo papa Paulo III em 1540, se instalando em Portugal e na Espanha, e estendendo sua atuação para a África, o Oriente e as Américas (VENTURINI, 2009). Segundo o administrador brasileiro Gil Uchôa Teixeira (1990, p. 12), "utilizou o ensino, a organização e a disciplina nos trabalhos de evangelização". Sendo seus principais pilares, de acordo com o padre jesuíta português Serafim Leite $(1938$, p. 5): "voto de castidade, voto de pobreza, voto de ir em peregrinação a Jerusalém e ocupar a vida e forças na salvação do próximo, administração dos sacramentos da confissão e comunhão, pregação e celebração da missa, tudo sem estipêndio".

Além disso, a historiadora brasileira Claudette Boff (2006) ressalta que seus trabalhos foram inspirados pelos ideais da Contrarreforma, sendo um de seus objetivos renovar e ampliar a atuação da Igreja Católica após o surgimento do Protestantismo no século XV. Por isso, segundo o padre inaciano Satilio Bolonhani (2006, p. 1), essa ordem religiosa atuava em diversos continentes 
sempre buscando o que Inácio de Loyola denominava MAGIS, dar mais, amar mais, servir mais. O primeiro grande missionário foi Francisco Xavier no Oriente, logo o seguiram outros: Mateo Ricci que viveu nos círculos do imperador chinês; José de Anchieta que fundou a cidade de São Paulo; e o peruano Antonio Ruiz de Montoya que iniciou as Reduções do Paraguai na época colonial.

A atuação da Companhia de Jesus nas Américas iniciou após o Tratado de Tordesilhas, firmado em 1494, cuja linha divisória de domínios é mostrada na Figura 1, na próxima página. De acordo com o arquiteto brasileiro Luiz Antonio Custódio (2006, p. 2), tal tratado estabelecia:

limites para as possessões decorrentes das descobertas das nações ibéricas [...]. A ocupação colonial do continente americano deu-se a partir e ao longo do litoral Atlântico pelos portugueses, e a partir do Caribe, de noroeste para o sudoeste, ao longo da costa pacífica, pelos espanhóis.

Além de uma aplicação de sua filosofia desbravadora e evangelizadora, as Missões Jesuíticas nas Américas foram criadas com a finalidade inicial de defender "os limites imperiais ampliados da Coroa da Espanha, que se estenderam - no Novo Mundo - desde a Califórnia e o Novo México até o Rio da Prata" (GAZANEO, 1997, p. 75, tradução nossa ${ }^{14}$ ), onde se localizam os Trinta Povos. Em relação à atuação da Companhia no Brasil, é preciso entender que, como enfatiza Ribeiro, quando da chegada dos portugueses à costa brasileira, os habitantes do continente "Somavam, talvez, 1 milhão de índios, divididos em dezenas de grupos tribais, cada um deles compreendendo um conglomerado de várias aldeias de trezentos a 2 mil habitantes (Fernandes, 1949). Não era pouca gente, porque Portugal àquela época teria a mesma população ou pouco mais" (RIBEIRO, 1995, p. 31). Dentre esta população, interessam em especial os indivíduos de cultura guarani, que

\footnotetext{
${ }^{14}$ Do original em inglês: "[...] the extended imperial borders of the Crown of Spain, which stretched - in the New World - from California and New Mexico to the River Plate" (GAZANEO, 1997, p. 75).
} 


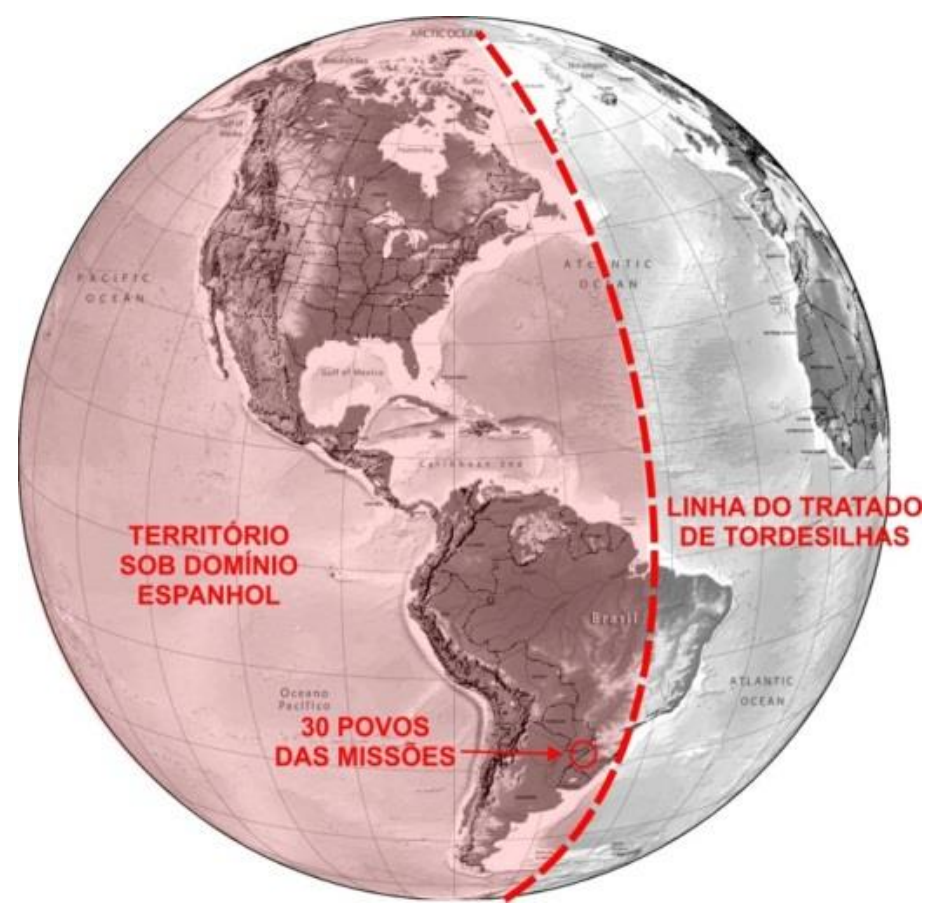

Figura 1. Tratado de Tordesilhas, mostrando o território sob domínio espanhol e a localização dos chamados Trinta Povos das Missões.

Fonte: Elaborada pela autora. 
habitavam principalmente a Amazônia, quando, já há cerca de 2000 anos atrás, emigraram para o Sul até a região do rio da Prata. Era uma sociedade característica do período paleolítico superior.

Tratava-se de grupos caçadores, coletores e horticultores. [...] Cultivavam apenas para a sobrevivência [...]. A floresta era indispensável; lá coletavam os alimentos, caçavam e pescavam. [...]

Muitas vezes eram obrigados a mudar suas tribos, em decorrência da falta de alimentos, do esgotamento das terras ou das disputas entre grupos (TEIXEIRA, 1990, p.14).

Portanto, de acordo com necessidades alimentícias, as tribos do tronco linguístico tupiguarani se deslocavam com certa frequência, migrando em função de sua maneira de utilizar a floresta como provedora de sustento. O que explica porque são encontradas desde a Amazônia até o Rio Grande do Sul.

De acordo com Bolonhani (2006), a maioria dos jesuítas ibero-hispânicos chegou ao Brasil em 1549, espalhando-se pelo litoral do país, incluindo Salvador, Ilhéus e São Vicente, além de cidades dos estados de Sergipe, Pernambuco, Paraíba e Maranhão. "Em 1605, os jesuítas já haviam se expandido de Natal à Ilha do Desterro, atual Florianópolis. Fundaram São Paulo e participaram da fundação de outras cidades, como Salvador e Rio de Janeiro" (BOLONHANI, 2006, p. 2).

Sua chegada ao Brasil deve-se em parte ao fato de que foi o único território das Américas a ficar dividido sob as influências das Coroas Portuguesa e Espanhola (Figura 1), o que resultou em um processo de colonização nacional marcado por dois fenômenos antagônicos (MONTEIRO, 1992, p. 476; GREENHALGH, 2004, p. 2). O primeiro é denominado bandeirantismo paulista, regionalmente brasileiro, que buscava mão-de-obra escrava indígena, em especial nos habitantes 
das Missões Jesuíticas por seu comportamento pacificado ${ }^{15}$ (ABREU, 1982 apud MONTEIRO, 1992,

p. 486). Já o segundo é chamado Missões Jesuíticas e está inscrito na América Latina como um todo, buscando através do trabalho de evangelização da Companhia de Jesus uma abordagem integradora em relação aos povos indígenas, que eram alvo de constantes ataques bandeirantes. Como será analisado mais adiante, este antagonismo produzirá diversos conflitos que culminarão em uma guerra envolvendo espanhóis, bandeirantes e habitantes das Reduções de 1750 a 1756, ocasionando o fim das Missões Jesuíticas e a destruição de grande parte de seu patrimônio material.

No âmbito político, de acordo com o padre brasileiro Jurandir Aguilar (2002), os assentamentos das Missões tiveram o propósito de desenvolver a economia local e aumentar a defesa das fronteiras. Segundo os relatos do padre jesuíta austríaco Antonio Sepp ${ }^{16}$ (1980 [1697], p. 12), "Durante mais de cem anos, os índios dos Trinta Povos combateram, pela Coroa espanhola, em mais de cinquenta batalhas".

Em termos religiosos, os habitantes do novo continente "seriam trazidos para a Igreja Cristã e educados em uma forma sedentária de vida" (UNESCO, 2013a, p. 3, tradução nossa ${ }^{17}$ ). E, acima de tudo, no campo social, "o projeto missioneiro jesuítico surgiu como uma proposta alternativa

\footnotetext{
${ }^{15}$ É importante salientar que o bandeirantismo paulista não buscava a mão-de-obra indígena exclusivamente nas missões jesuíticas e, portanto, não estava estritamente ligado a elas.

16 “Pe. Antonio Sepp (1655-1733) nasceu no Tirol. Quando entrou para a Cia. de Jesus, aos 9 anos, já era músico exímio. Com 36 anos veio para as Missões. Fundou a Missão de São João Batista (1797), perto de S. Ângelo. Mais conhecido por ter introduzido a siderurgia no Rio Grande do Sul. Seu maior destaque, entretanto, foi a música, sendo o principal professor de música da história missioneira" (ANDRIOTTI, 1995, p. 19). Sepp escreveu "Viagem às Missões Jesuíticas e trabalhos apostólicos", a mais importante referência existente sobre o cotidiano missioneiro.

${ }^{17}$ Do original em inglês: "[...] they would be brought into the Christian Church and educated into a sedentary form of life" (UNESCO, 2013a, p. 3).
} 
diante da brutalidade do regime da encomienda ${ }^{18}$ e da escravidão gerados nas cidades de Assunção e São Paulo, respectivamente" (SNIHUR, 2007, p. 236). O historiador Sergio Venturini acrescenta que, em troca de sua liberação de cumprir a encomienda individual,

Os Guarani missioneiros pagavam impostos ao rei da Espanha [...] Em mais de uma oportunidade houve discussão entre os jesuítas e as autoridades espanholas em relação ao pagamento dos impostos. O rei determinava um valor de imposto, que correspondia a um peso por ano para cada índio adulto. Os padres afirmavam que era menor o valor a ser pago, e questionavam defendendo a ideia de que o Guarani, enquanto soldado, não deveria pagar impostos e, sim, ser indenizado pelo governo (VENTURINI, 2009, p. 44).

Sobre a atuação da Companhia de Jesus em solo sul-americano, o historiador argentino Esteban Snihur (2007, p. 49) afirma que:

[...] Em 1549, menos de uma década após a criação da Companhia de Jesus, o Padre Manoel da Nóbrega fundou a Província Jesuítica do Brasil, a primeira que esta ordem instalou em terras americanas e cuja sede estava em São Paulo. Anos mais tarde, em 1568, foi fundada a Província Jesuítica do Peru, primeira em território espanhol. [...].

De cujo território se desmembrou, em 1604, a Província Jesuítica do Paraguai (VENTURINI, 2009, p. 27), um dos objetos de estudo dessa pesquisa. Sua primeira redução foi fundada em 1609: San Ignácio Guazú, no atual Paraguai. De acordo com Boff (2006, p. 2), a atuação jesuítica no território brasileiro “Iniciou-se na região do Guairá, ocupando logo após a região do Itatim e se

\footnotetext{
${ }^{18}$ Encomienda era uma medida implementada pela Coroa Espanhola, que obrigava os indígenas a pagarem impostos ou trabalharem gratuitamente para a Coroa como forma de pagamento pelos serviços de catequização prestados pela corte. Embora os habitantes das missões jesuíticas tenham sido liberados da encomienda individual, ainda pagavam a encomienda coletiva com produtos para o governo (CUSTÓDIO, 2014).
} 


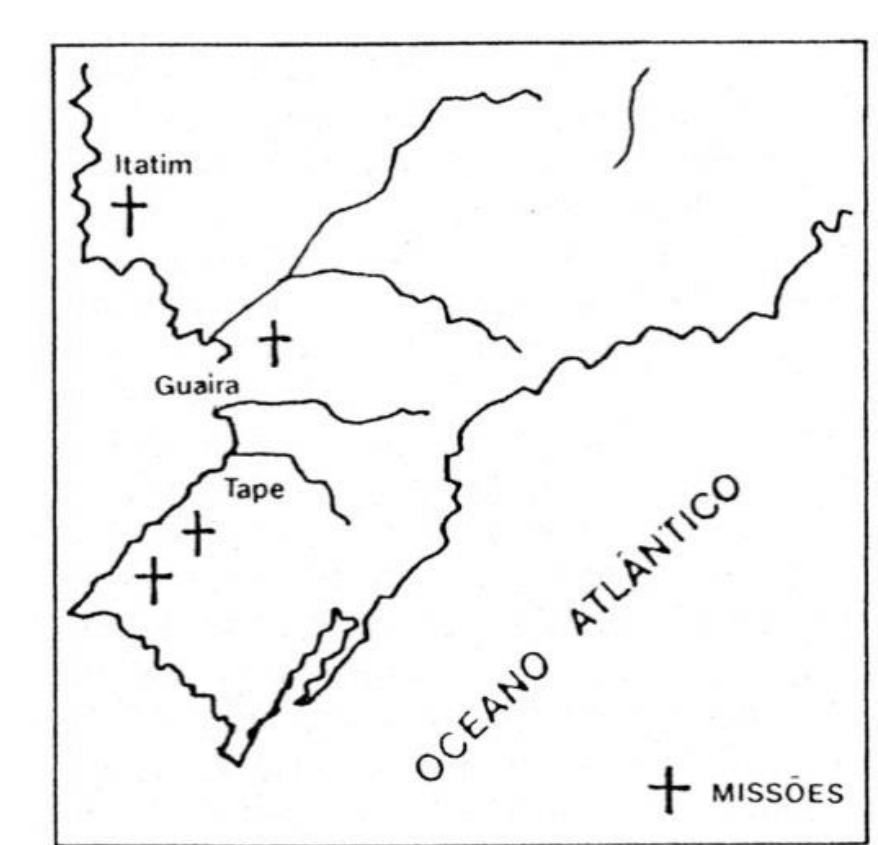


estendendo até o Tape ${ }^{19}$, no sul do Brasil”, Figura 2, na página ao lado.

A primeira região a ser ocupada, o Guaíra se espalhava entre o Paraná e o Atlântico e, aproximadamente, o Rio Tietê ao norte e o Iguaçu ao sul, era no início do século 16 o habitat central dos Guarani, cuja língua nos permite reconhecer um parentesco com o Tupi e, mais distantemente, os Caribenhos e os Araucanos, entre outros [...] (PAULA, 1997, p. 91, tradução nossa ${ }^{20}$ ).

A proximidade da região do Guaíra com São Paulo facilitava as constantes investidas dos bandeirantes paulistas em busca de minérios ${ }^{21}$ e de indígenas para escravização. De acordo com Ribeiro, esta demanda por mão-de-obra indígena surgiu porque,

Custando uma quinta parte do preço de um negro importado, o índio cativo se converteu no escravo dos pobres, numa sociedade em que os europeus deixaram de fazer qualquer trabalho manual. Toda tarefa cansativa, fora do eito privilegiado da economia de exportação, que cabia aos negros, recaía sobre o índio (RIBEIRO, 1995, p. 100).

Devido às investidas dos bandeirantes, os habitantes das primeiras Missões viram-se obrigados a buscar refúgio em outras Reduções mais distantes, ocasionando um êxodo das Reduções jesuíticas do Guaíra e do Itatim, e posteriormente do Tape. Segundo relatos do Padre Sepp, padres e indígenas seguiram "através das selvas, por lugares ainda hoje impenetráveis,

${ }^{19}$ O Guaíra hoje está localizado no Oeste do Paraná; o Itatim no Sul do Mato Grosso do Sul; e o Tape no Centro do Rio Grande do Sul.

${ }^{20}$ Do original em inglês: "The Guayrá, the region that in ancient South America spread out between the Paraná and the Atlantic and, approximately, the Tieté River to the north and the Iguazú in the south, was at the beginning of the 16th century the central habitat of the Guaranis, whose language permits us to recognize a kinship with the Tupis and, more distantly, the Caribs and the Araucans, among others" (PAULA, 1997, p. 91).

${ }^{21}$ De acordo com Snihur (2007), no século XVI, Sebastián Gaboto [1476-1557] realizou uma incursão pelo Rio da Prata para descobrir uma ligação entre os dois oceanos e "À medida que percorria o litoral encontrou um grande número de povoados indígenas que o presentearam com objetos feitos com estes dois metais [ouro e prata]" (SNIHUR, 2007, p. 31). As notícias levaram os bandeirantes a buscar por estes minérios. 


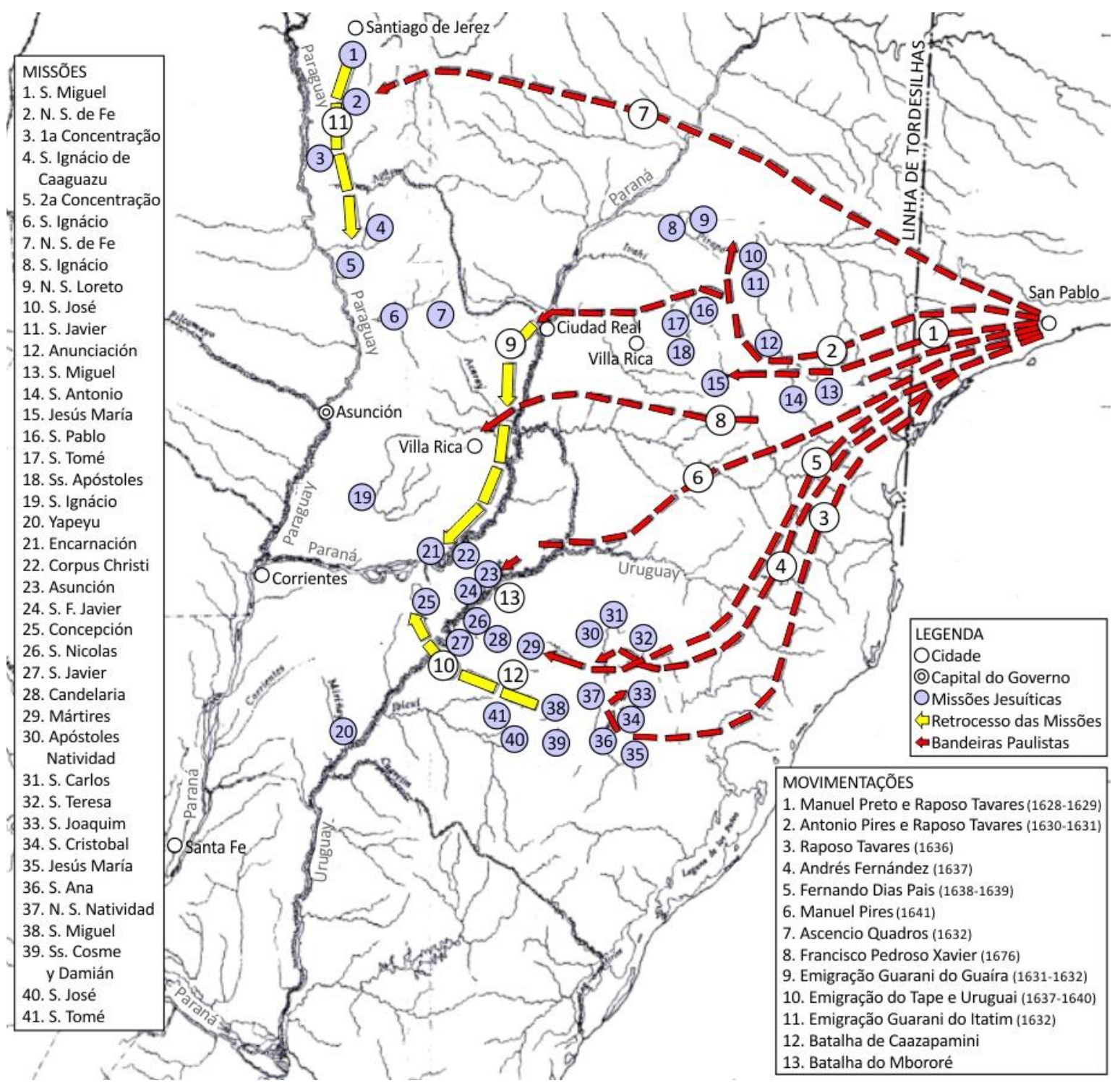

Figura 3. Avanços dos bandeirantes e retrocessos dos jesuítas e indígenas.

Fonte: MAEDER; GUTIÉRREZ, 2010, p. 22, tradução, cores e numerações nossas. 
rumo às Reduções do Paraná e Alto-Uruguai, sendo aí carinhosamente acolhidos" (SEPP, 1980 [1697], p.10). Segundo o jornalista José Machado Leal (2008), o período de fuga se estendeu de 1609 a 1637 e produziu uma migração para o sudoeste, para longe do assédio bandeirante.

As movimentações de bandeirantes e missioneiros são traçadas em um mapa produzido pelo historiador Ernesto Maeder e pelo arquiteto Ramón Gutiérrez e apresentado no livro "Atlas territorial e urbano das Missões Jesuíticas dos guarani: Argentina, Paraguai e Brasil”, escrito em duas línguas (espanhol e português) (Figura 3, na página ao lado): por um lado as investidas bandeirantes, representada por linhas vermelhas; e, por outro, as rotas de fuga dos missioneiros, em linhas amarelas. Pode-se perceber que todas as bandeiras ${ }^{22}$ partem de São Paulo e direcionam-se a uma área muito vasta, que abrange desde a região do Itatim (atualmente Oeste do Mato Grosso do Sul) até o Tape (atualmente interior do Rio Grande do Sul). De acordo com os mesmos autores, as maiores bandeiras foram "comandadas por Antonio Raposo Tavares e Manuel Preto (1628-1629) [1]] e pelo mesmo Raposo Tavares e Antonio Pires (1630-1631) [(2)]" (MAEDER; GUTIÉRREZ, 2010, p. 23). Estas também são as duas primeiras bandeiras registradas pelos autores, o que pode ser um fator importante para explicar sua grandeza, já que a partir delas os missioneiros souberam da existência desta ameaça e decidiram busca abrigo em terras mais distantes como forma de proteção.

A bandeira de Raposo Tavares e Manuel Preto (1) terminou na missão de Jesus Maria, já a de Raposo Tavares juntamente com Antonio Pires (2) dividiu-se em duas frentes: uma chegou à

\footnotetext{
22 O termo "bandeira" designa as incursões realizadas pelo interior do Brasil, durante o período de desbravamento das matas, a partir do século XVI. Também chamados de sertanistas, os bandeirantes partiam de São Paulo em busca de riquezas minerais, índios para escravização, ou para destruir quilombos.
} 
missão de Nuestra Señora de Loreto (em sua primeira localização ao noroeste de São Paulo) e a outra à cidade denominada Ciudade Real. Ao todo, os autores retratam oito bandeiras consideradas importantes e três rotas de fuga missioneiras, e destacam que inclusive as cidades de Villa Rica e Ciudade Real se viram obrigadas a abandonar a região em 1632.

Este mapa ainda nos revela o grande número de Reduções que deixaram de existir (tais como Jesus María del Ibiticaray, Santo Antonio, Nuestra Señora de Natividade, entre tantas outras) e também aquelas que sobreviveram aos ataques e foram refundadas posteriormente em locais diferentes (como São Miguel Arcanjo, localizada inicialmente no Mato Grosso do Sul e refundada posteriormente no estado do Rio Grande do Sul). De acordo com Leal (2008, p. 21), essa movimentação ocorreu da seguinte forma: "À medida que os bandeirantes atacavam as Missões do Itatim, no sul do Mato Grosso, os habitantes das missões deslocavam suas ações para o interior do Paraguai guiados pelos jesuítas, depois para o nordeste argentino e Missões Orientais do Uruguai". Nesta região foram gentilmente acolhidos e permaneceram até ficarem

livres, enfim, do perigo dos ataques bandeirantes, [...] [quando então] começaram a retornar para a região do Tape [de onde algumas reduções também precisaram fugir do assédio bandeirante]. Lá, deram início a novas reduções, que se constituíram nos SETE POVOS da bancada oriental do rio Uruguai, hoje em território gaúcho (TEIXEIRA, 1990, p. 15).

De acordo com Maeder e Gutiérrez (2010), as bandeiras reduziram o número de Reduções quase pela metade e, segundo Leite (1938), entre a fuga e o retorno ao território brasileiro para a fundação de novos povoamentos, passaram-se 45 anos (de 1637 a 1682). Mas este processo modificou de forma definitiva a configuração geográfica das Missões Jesuíticas, que passaram a se concentrar em uma região mais a sudoeste da inicial. 
Após essas reconfigurações geográficas, as Missões Jesuíticas reduziram-se ao número de Trinta Povos, que sobreviveram a este processo histórico. Os remanescentes dos aldeamentos atualmente estão situados nos territórios da Argentina, do Brasil e do Paraguai, conforme pode ser visto na Figura 4, na próxima página ${ }^{23}$. Segundo esta conformação em território brasileiro estão localizados sete Povos (Santo Ângelo, São Borja, São João Batista, São Lourenço, São Luiz, São Miguel e São Nicolau); no Paraguai localizam-se oito, distribuídos pelas províncias de Misiones e Itapua (Encarnación, Jesús de Tavarangue, San Cosme y Damián, San Ignácio, Santa María, Santa Rosa, Santiago de las Misiones e Trinidad); e na Argentina estão 15 (Apóstoles, Candelaria, Concepción de la Sierra, Corpus, La Cruz, Loreto, Mártires, San Carlos, San Ignácio Miní, San Javier, San José, Santa Ana, Santa María Mayor, Santo Tomé e Yapeyú) ${ }^{24}$.

Na Tabela 1 (na página 36), são apresentadas as cidades atuais em que se encontram os sítios das Missões Jesuíticas. Embora a maioria destas cidades não tenha sido gerada sobre o traçado urbano original das Reduções Jesuíticas devido a seu estado avançado de destruição, "a infraestrutura dos caminhos continuou viva sobre o território, determinando os novos processos de povoamento e o modo de ocupação do espaço e os recursos. As colônias agrícolas criadas no final do século XIX tomaram como base territorial as áreas das antigas reduções em ruínas" (SNIHUR, 2007, p. 114).

\footnotetext{
${ }^{23}$ Havia ainda uma região de estâncias e ervais localizada atualmente em território uruguaio. A figura mostra a localização final das missões. Algumas delas foram fundadas inicialmente em outros locais (ver Figura 3, na página 30).

${ }^{24}$ Como mencionado anteriormente, foram fundadas missões jesuíticas por toda a América. Algumas muito bem conservadas localizam-se atualmente na Bolívia, contudo não serão analisadas por não fazerem parte do conjunto escolhido para estudo nesta pesquisa, que abrange a chamada Província Jesuítica do Paraguai, compreendendo as reduções citadas neste parágrafo.
} 


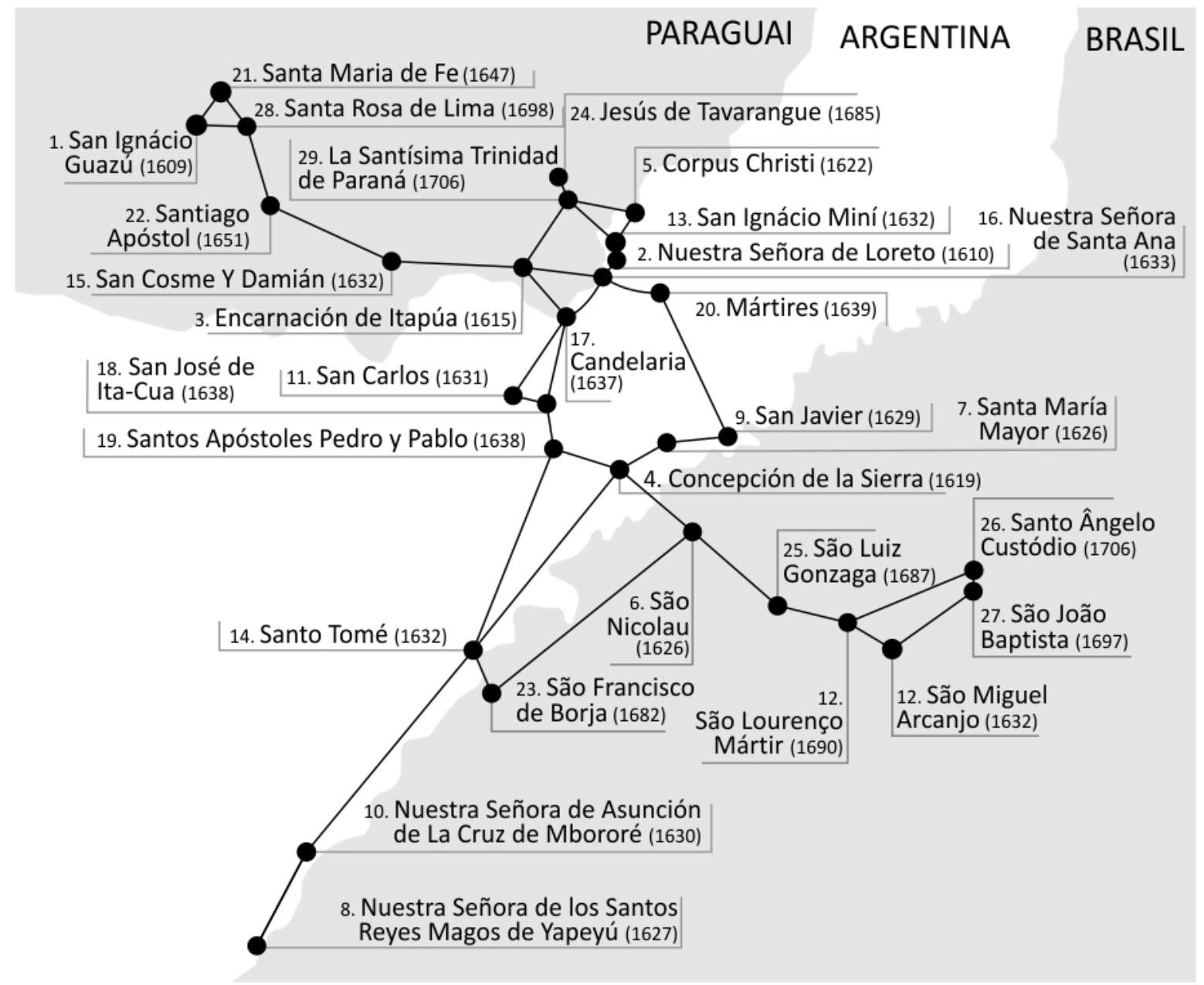

Figura 4. Os Trinta Povos das Missões com suas datas e ordem de fundação. Fonte: Elaborada pela autora. 
As constantes investidas bandeirantes sobre as Reduções tornaram-se razão suficiente para que a Corte Espanhola permitisse o uso de armas de fogo pelos habitantes missioneiros; o que, segundo o padre Arnaldo Bruxels (1984), não era permitido até 1640, mas fez-se necessário para o cumprimento de uma das principais funções das Missões Jesuíticas: a defesa do território correspondente à Coroa Espanhola, como já mencionado. O autor ainda comenta que até esta data, "[...] a proximidade entre os povos era imprescindível para a segurança comum" (BRUXELS, 1984 , p. 23 , tradução nossa ${ }^{25}$ ), o que pode ser constatado inclusive durante as fugas, quando habitantes de Reduções atacadas puderam abrigar-se em outras mais distantes.

Em 1750, as Coroas Espanhola e Portuguesa firmaram o Tratado de Madrid (Figura 5, na página 38), estabelecendo nova divisão das terras das Américas, em parte para corrigir a desigualdade de posses ocorrida com o Tratado anterior. O novo acordo também teve causas locais. Segundo Snihur (2007, p. 169),

Desde o momento do seu estabelecimento nas terras do Paraná e do Uruguai, as missões jesuíticas despertaram antipatias e temores. E era compreensível, pois os padres da Companhia de Jesus eram, para estes moradores, os responsáveis pela privação da mão-de-obra indígena utilizada no regime da encomenda. A riqueza agropecuária dessas cidades se baseava na exploração do trabalho indígena submetido ao regime encomendeiro, o que tornava as reduções jesuíticas em uma opção de libertação para os guaranis. [...]

[...] Na Europa, em virtude do movimento intelectual da llustração, [...] gerarase uma tenaz oposição combativa contra a Companhia, que era acusada de provocar intrigas políticas nas cortes das monarquias europeias.

\footnotetext{
${ }^{25}$ Do original em espanhol: "[...] la proximidad entre los Pueblos era imprescindible para la seguridad común [...]" (BRUXELS, 1984, p. 23).
} 


\section{Os Trinta Povos}

* Missões que mudaram de localização ao longo da história. § Declarada patrimônio da humanidade pela UNESCO.

\begin{tabular}{|c|c|c|c|}
\hline Ano & Nome & Fundador(es) & Atual cidade \\
\hline 1609 & San Ignacio Guazú & $\begin{array}{l}\text { Marcelo de Lorenzana, Francisco de } \\
\text { San Martín e Cacique Arapysandú. }\end{array}$ & San Ignácio_Paraguai \\
\hline 1610 & Nuestra Señora de Loreto $\S$ & José Cataldino e Simón Maceta. & Loreto_Argentina \\
\hline 1615 & Encarnación de Itapua & Roque Gonzales de Santa Cruz. & Encarnación_Paraguai \\
\hline 1619 & Concepción de la Sierra & Roque Gonzales de Santa Cruz. & Concepción_Argentina \\
\hline 1622 & Corpus Christi & Roque Gonzales de Santa Cruz. & Corpus_Argentina \\
\hline 1626 & São Nicolau & Roque Gonzales de Santa Cruz. & São Nicolau_Brasil \\
\hline $1626 / 1767^{*}$ & Santa Maria Mayor $\S$ & Cláudio Ruyer e Diego Boroa. & Santa María Mayor_Argentina \\
\hline 1627 & $\begin{array}{l}\text { Nuestra Señora de los Santos } \\
\text { Reyes Magos de Yapeyú }\end{array}$ & $\begin{array}{l}\text { Pedro Romero, Roque Gonzales } \\
\text { de Santa Cruz e Nicolás Mastrilli Durán. }\end{array}$ & Yapeyú_Argentina \\
\hline 1629 & San Javier & José Ordoñez. & San Javier__Argentina \\
\hline 1630 & $\begin{array}{l}\text { Nuestra Señora de Asunción } \\
\text { de La Cruz de Mbororé }\end{array}$ & Cristóbal Altamirano. & La Cruz_Argentina \\
\hline 1631 & San Carlos & Pedro Molas. & San Carlos_Argentina \\
\hline $1632 / 1687^{*}$ & São Miguel Arcanjo § & Cristóvão de Mendonça. & São Miguel das Missões__Brasil \\
\hline 1632 & San Ignacio Miní § & Roque Gonzales de Santa Cruz. & San Ignácio Miní_Argentina \\
\hline $1632 / 1683^{*}$ & Santo Tomé & Luis Ernot. & Santo Tomé_Argentina \\
\hline 1632 & San Cosme y Damián & Adriano Formoso. & San Cosme Y Damián_Paraguai \\
\hline $1633 / 1637^{*}$ & Nuestra Señora de Santa Ana § & Pedro Romero. & Santa Ana_Argentina \\
\hline $1637 / 1665^{*}$ & Candelaria & Roque Gonzales de Santa Cruz. & Candelaria_Argentina \\
\hline 1638 & Santos Apóstoles Pedro y Pablo & Diego de Alfaro. & Apóstoles_Argentina \\
\hline $1638 / 1660^{*}$ & San José de Ita-Cua & José Cataldino. & San José_Argentina \\
\hline 1639 & Mártires & Augustín Contretas. & Mártires_Argentina \\
\hline 1647 & Santa María de Fe & Manuel Berthod. & Santa María_Paraguai \\
\hline 1651/1669* & Santiago Apóstol & --- & Santiago_Paraguai \\
\hline 1682 & São Francisco de Borja & Francisco Garcia. & São Borja_Brasil \\
\hline 1685 & Jesús de Tavarangue $\S$ & Jerónimo Delfin. & Jesús de Tavarangue_Paraguai \\
\hline 1687 & São Luiz Gonzaga & Alfonso del Castillo. & São Luiz Gonzaga_Brasil \\
\hline 1690 & São Lourenço Mártir & Bernardo de la Veja. & São Lourenço_Brasil \\
\hline 1697 & São João Baptista & Antonio Sepp. & Entre-ljuís_Brasil \\
\hline 1698 & Santa Rosa de Lima & Ranzonier. & Santa Rosa_Paraguai \\
\hline 1706 & Santo Ângelo Custódio & Diogo de Hasse. & Santo Ângelo__Brasil \\
\hline 1706 & La Santísima Trinidad de Paraná § & Juan de Anaya. & Trinidad_Paraguai \\
\hline
\end{tabular}

Tabela 1. Missões Jesuíticas com suas datas de fundação, seus fundadores e atual cidade onde se localizam.

Fonte: Elaborada pela autora. 
De acordo com Venturini (2009, p. 47), a nova linha traçada para a fronteira respeitou o país que ocupava as terras. A única exceção foi Colônia de Sacramento, que era uma ocupação portuguesa em meio ao território espanhol. Esta região foi trocada pelos chamados Sete Povos ${ }^{26}$ das Missões Orientais do Uruguai, que passaram ao domínio português. Dessa maneira, uma ordem superior da Coroa Espanhola e da Companhia de Jesus determinou que estas Reduções fossem abandonadas pelos missioneiros, que deveriam se dirigir para a margem esquerda do Rio Uruguai "num curto espaço de tempo e com uma irrisória indenização no valor inferior a $10 \%$ do que realmente valiam" (VENTURINI, 2009, p. 47). Por obediência aos superiores, os padres precisaram convencer os Guarani a deixarem as Reduções. Para os Guarani dos Sete Povos Orientais a questão era ainda mais complicada. Como afirma Custódio (2014) aquela era uma terra construída pelos indígenas e eles não a iria abandonar. Visto que os Guarani não aceitaram a ordem espanhola, Portugal e Espanha uniram seus exércitos para combatê-los e partiram para a região gaúcha em 1752. As batalhas da Guerra Guaranítica iniciaram em 1754, ocorrendo em campo aberto, longe das Reduções, e os habitantes de São Miguel se destacaram em batalha como ponto de resistência sob a liderança do cacique do cabildo, Sepé Tiaraju. A guerra durou aproximadamente dois anos e, após esse período, foram colocados os novos marcos de fronteira. Ao final da guerra, uma parcela dos habitantes conseguiu fugir com alguns pertences (que constituem hoje boa parte do patrimônio material missioneiro que foi salvo), e a Coroa Portuguesa denominou encarregados administrativos para as missões não destruídas. De acordo com Venturini (2009), os fugitivos que atravessaram o Rio Uruguai não retornaram à vida na selva, pois já haviam incorporado a cultura urbana. Já os jesuítas foram expulsos definitivamente

\footnotetext{
${ }^{26}$ Segundo Custódio (2014), esta é uma denominação posterior à época jesuítica, que possui imbuído o sentido dos Sete Povos que se rebelaram.
} 


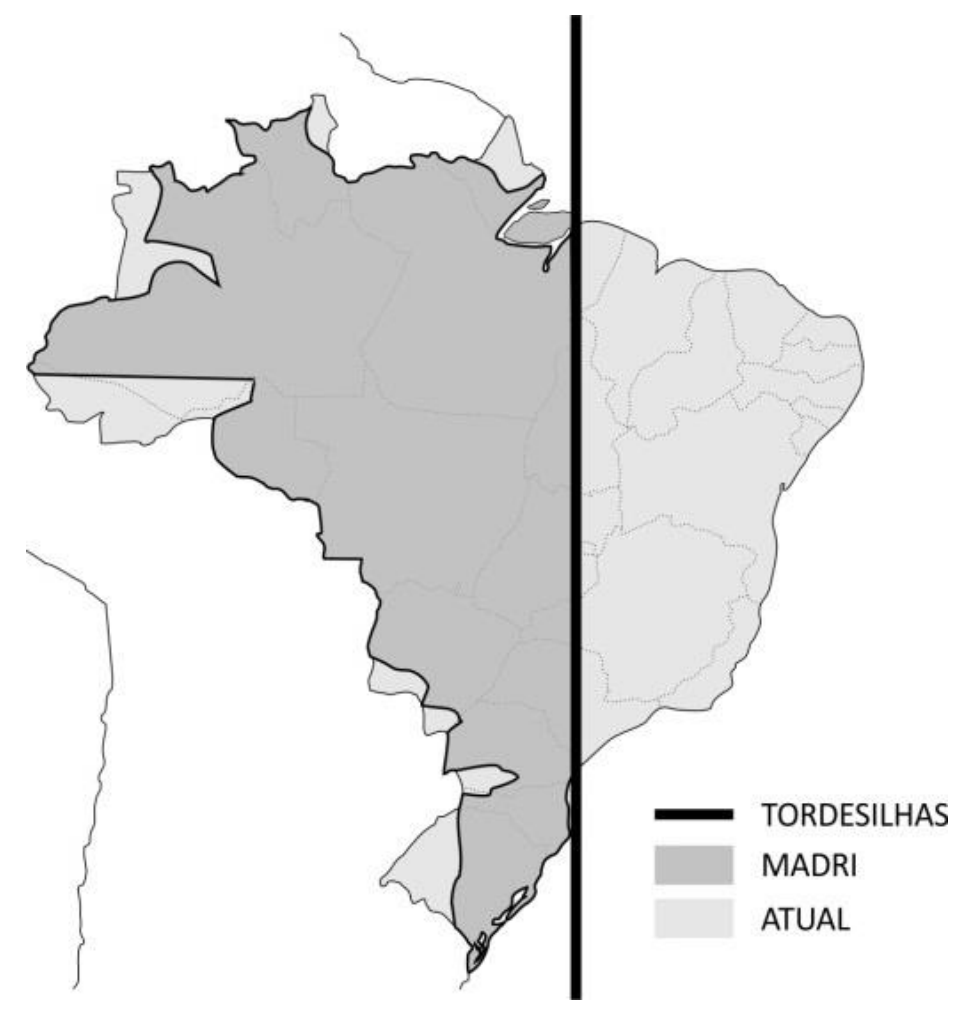

Figura 5. Distribuição do território brasileiro com o Tratado de Madri. Fonte: Elaborada pela autora. 
de todos os territórios espanhóis em 1768, pois foram acusados de instigar a resistência durante a Guerra Guaranítica.

"Os padres dominicanos, franciscanos e mercedários que substituíram os jesuítas não tinham a formação intelectual e científica dos padres da Companhia de Jesus, e nem a formação religiosa e a liderança dos jesuítas junto aos índios, e isso foi uma das causas da decadência dos povos missioneiros" (VENTURINI, 2009, p. 52). Isso porque a experiência jesuítica proporcionou aos seus habitantes uma impressão de independência econômica, social e religiosa através de uma liderança paralela exercida pelos caciques e suas tribos. Neste contexto, os historiadores brasileiros Jean Baptista e Maria Cristina dos Santos (2009, p. 39), apresentam informações de documentos da época que atestam o seguinte: "o governador das Missões afirma [...] que os indígenas não se adaptarão à nova divisão de poderes, tanto por sentirem falta de 'seus sacerdotes', quanto por seu tradicional modo de vida prescrever a conjunção dos poderes político e religioso".

O novo sistema de governo caracterizou a "fuga dos indígenas do povoado e a consequente queda na produção" (BAPTISTA; SANTOS, 2009, p. 52), sendo que o encarregado administrativo de uma das províncias afirmou em carta ao vice-rei que "O meio para evitar o golpe decisivo que se avizinha é somente um: reduzir os povoados ao seu antigo governo, deixando aos seus sacerdotes a livre administração de tudo o que possuem e produzem, sob as ordens, instruções e responsabilidade do Governo Superior do Rio da Prata" (BAPTISTA; SANTOS, 2009, p. 52).

“Da experiência missioneira, restou uma enorme contribuição cultural e econômica na região, além de preciosos vestígios arquitetônicos, artísticos e arqueológicos. Seu significado e sua importância têm suscitado diferentes interpretações e discussões apaixonadas. Deixaram 
personagens famosos e muitas lendas" (CUSTÓDIO, 2000b, p. 39, tradução nossa ${ }^{27}$ ). Durante a guerra, os habitantes das Reduções mostraram a importância desta construção histórica ao lutarem contra sua expulsão. O que foi eternizado, segundo a doutora em antropologia brasileira Ceres Brum (2007, p. 223), no grito atribuído a Sepé Tiaraju, líder guarani da resistência missioneira: "Esta terra tem dono". Mas, muito além do apego à redução jesuítica que construíram e onde habitavam, essa frase remete à importância da sociedade onde viviam, que foi construída pela interação entre a cultura dos povos pré-colombianos que aqui habitavam.

\section{2 o conjunto e a unidade: Urbanismo e Arquitetura}

Em meados do ano de 1586, de acordo com o Padre Antonio Sepp (1980, p. 9), os jesuítas utilizavam inicialmente um sistema de missões ambulantes, em que acompanhavam as tribos em suas movimentações na tentativa de aproximação e conversão. Segundo ele, somente 21 anos depois, "Pelo ano de 1607, adotou-se o sistema de Reduções. As aldeias agora cristãs eram chamadas 'reduções' porque 'ad ecclesiam et vitam civilem essent reducti'” (SEPP, 1980 [1697], p. 9). A expressão vem do latim e significa "para a igreja e para a vida social foram trazidos de volta", sendo que reducti significa "de volta". Portanto, o intuito dos aldeamentos criados pelos jesuítas era o de trazer os habitantes das tribos para uma vida social junto à igreja católica. De acordo com

\footnotetext{
${ }^{27}$ Do original em espanhol: “De la experiencia misionera, restó una enorme contribución cultural y económica en la región, además de preciosos restos arquitectónicos, artísticos y arqueológicos. Su significado y su importancia han suscitado diferentes interpretaciones y discusiones apasionadas. Dejaron personajes famosos y muchas leyendas" (CUSTÓDIO, 2000b, p. 39).
} 
Custódio (2000b, p. 36, tradução nossa ${ }^{28}$ ), "Neste processo, se constituíram povos criados adotando as disposições espanholas para a fundação de novas cidades e articulados com estâncias e espaços por meio de rotas e portos fluviais".

O profundo vínculo existente entre as Reduções pode ser percebido quando padres e indígenas precisaram fugir das investidas bandeirantes e recebiam refúgio em outras Reduções. De acordo com o engenheiro argentino Carlos Eduardo Rovira (2007, p. 5), os padres

planejaram uma forte estrutura de contenção física entre os 30 povoados das Missões, cujo lugar de reunião foi a Redução. Mas, ao mesmo tempo, outorgaram a mesma hierarquia a uma ampla e consolidada rede de caminhos que garantisse a comunicação, o intercâmbio econômico e, principalmente, a equidade na repartição dos benefícios que a produção para um projeto de região integrada acarreta.

Fazem parte de tais benefícios os frutos das diversas tecnologias introduzidas pelos jesuítas conforme seus conhecimentos, a necessidade de cada missão e a possibilidade de cada local e povo. Dentre elas, o arquiteto e doutor em história brasileiro Marcos Carrilho (2006, p. 1) destaca que "Desenvolviam produção diversificada de utensílios de uso corrente e cultivavam as artes". De acordo com Ribeiro (1995, p. 170), o projeto jesuítico foi estruturado "com base na tradição solidária dos grupos indígenas e consolida-se com os experimentos missionários de organização comunitária, de caráter proto-socialista $29 "$.

${ }^{28}$ Do original em espanhol: “[...] En ese proceso, se constituyeron pueblos creados adoptando las disposiciones españolas para la fundación de nuevas ciudades y articulados con estancias y espacios por medio de rutas y puertos fluviales" (CUSTÓDIO, 2000b, p. 36).

${ }^{29}$ Segundo o doutor em História Angelo Segrillo (2005), o proto-socialismo é um regime político que não é totalmente socialista. 
Novamente percebe-se aqui a importância do conjunto para as unidades e vice-versa. Esta característica de rede entre as Reduções foi possibilitada, em parte, pelas especificações feitas para sua implantação. Segundo o Padre José Cardiel (apud BRUXELS, 1984, p. 23), a distância entre as Reduções não deveria ultrapassar quinze quilômetros, pois equivalia a um dia de viagem a pé na época. Admitia-se até 55 quilômetros de distância em casos especiais. Neste contexto, construíram "um ótimo sistema de comunicação e transporte, como pontes de madeira ou pedra nos arroios, e disponibilidade de barcos para a travessia de rios maiores" (VENTURINI, 2009, p. 39). De acordo com Snihur (2007, p. 110), “Os povoados costeiros contavam com bons portos que garantiam a navegação dos rios Paraná e Uruguai". Sendo as Reduções portuárias do rio Paraná as seguintes: Candelaria, Santa Ana, Loreto, San Ignácio, Corpus, Itapua, Trinidad e Jesus. De tal forma que "rios ligavam, uniam, integravam os povoados e não constituíam um empecilho para as comunicações" (SNIHUR, 2007, p. 114). O que permitia uma comunicação facilitada entre as Reduções e um sistema de ajuda mútua, que era importante para a segurança do conjunto e as trocas de produtos.

Em relação aos caminhos terrestres, o Padre Cardiel (apud Snihur, 2007, p. 108) salienta que "A cada cinco léguas, nas Missões há uma capela, com um ou dois quartos, e uma ou mais casas de índios que a vigiam; e servem os quartos [...] de pousada para os passageiros". O que possibilitava que pessoas e animais descansassem para se recompor durante viagens muito longas. Dessa forma, os caminhos estavam preparados para favorecer o seu uso da maneira mais confortável possível à época, garantindo uma movimentação eficiente e rápida de pessoas e bens, que também era influenciada pela maestria na execução e manutenção dos mesmos. Embora houvesse essa rede interna entre as Reduções, o mesmo não ocorria com o exterior de seu território. De acordo com Snihur (2007, p. 108), “As vias de comunicação que ligavam as missões 
com o resto do mundo colonial eram escassas", e seu isolamento também era facilitado pelos acidentes naturais existentes nos limites de sua localização. O que facilitava o controle das comunicações das e para as missões.

Diante do exposto acima, esta pesquisa entende que esta experiência histórica pode ser lida sob o viés do pensamento sistêmico, já que as Missões Jesuíticas eram concebidas como um conjunto integrado, onde a unidade era parte de um todo e contribuía para sua realização e manutenção. Havia uma preocupação com a integração entre os povoados para possibilitar um auxílio mútuo para a própria sobrevivência deste conjunto.

Em relação ao local de implantação das Reduções, haviam especificações que são apresentadas nos escritos de Bruxels (1984, p. 22, tradução nossa ${ }^{30}$ ):

[...] o lugar para uma Redução deve medir no mínimo cem hectares de terreno plano, algo alto e aberto para o sul, de onde sopram os ventos frescos, deve ser provido de água em abundância, tanto para beber e para as necessidades da cozinha, como para permitir frequentes banhos, aos quais o indígena era muito afeiçoado, possuir bosques frondosos provedores de lenha e madeira para as construções, estar situados longe dos banhados, fontes de neblinas, incestos, sapos e víboras.

Tais especificações provinham um local salubre para as Reduções e satisfazia as necessidades básicas de seus habitantes.

${ }^{30}$ Do original em espanhol: "[...] el lugar para una Reducción debe medir como mínimo cien hectáreas de terreno plano, algo alto y abierto hacia el sur, de donde soplan los vientos frescos, debe estar provisto de agua en abundancia, tanto para beber y menesteres de cocina como para permitir frecuentes baños, a los que el indígena era muy afecto, poseer bosques frondosos proveedores de Lena y madera para las construcciones, estar situados lejos de los bañados, fuentes de neblinas, insectos, sapos y víboras" (BRUXELS, 1984, p. 22). 
Além dessas instruções de distâncias entre Reduções para possibilidade de auxílio entre elas e de local ideal para implantação de uma redução, também havia "um modelo de urbanização que foi aplicado, com pequenas variações, nos trinta povoados" (CUSTÓDIO, 1997, p. 3), onde cada elemento tinha sua importância específica para o funcionamento da redução como um todo. Muitos aspectos dessa implantação são decorrentes de fatores socioculturais. O que reforça a ideia de que os subsistemas econômico, político, cultural, entre outros, envolvidos no sistema maior das Missões Jesuíticas não podem ser explicados isoladamente. De modo que a estrutura arquitetônica e a organização espacial dos aldeamentos eram muito bem desenhadas e constituídas para abrigar uma formação sociocultural muito rica e esta lhe servia de embasamento, numa lógica recursiva.

De acordo com Custódio (2000b, p. 37, tradução nossa ${ }^{31}$ ), “Os povos eram construídos tendo em conta a influência das cidades ideais do Renascimento, com traçados geométricos que configuravam um modelo de assentamento urbano diferenciado dos padrões coloniais, todavia pouco conhecidos na história do urbanismo mundial". Este modelo urbanístico foi formulado especificamente para a atuação da Companhia de Jesus nas Américas e, portanto, não possui precedentes na Europa. Já Snihur (2007, p. 85) afirma que, "Na hora de estabelecer as reduções, o sentido prático foi a principal regra. [...]".

É importante salientar que as Missões Jesuíticas não foram a primeira experiência de evangelização dos guarani.

\footnotetext{
${ }^{31}$ Do original em espanhol: "Lo pueblos eran construidos teniendo en cuenta la influencia de las ciudades ideales del Renacimiento, con trazados geométricos que configuraban un modelo de asentamiento urbano diferenciado de los patrones coloniales, todavía poco conocidos en la historia del urbanismo mundial" (CUSTÓDIO, 2000b, p. 37).
} 
Quando a Província Jesuítica do Paraguai foi fundada no ano 1603, já existia uma tradição histórica relativa ao urbanismo dos povoados de índios. $\mathrm{Na}$ verdade, poderia ser feita uma classificação de várias etapas: a vila guarani préhispânica ou teko'a, sempre de caráter temporário; a vila guarani a cargo do "poblero", própria do regime da encomenda e fixada em um âmbito territorial específico, com o objetivo de evangelizar o guarani e torná-lo sedentário; a redução franciscana, com maior tendência ao processo evangelizador, mas ainda ligada ao sistema da encomenda; e, por último, a redução jesuítica (SNIHUR, 2007, p. 86).

Como pode ser visto nas Figuras 6 (na próxima página) e 7 (na página 48), o acesso principal à redução era realizado por uma avenida posicionada de frente para o eixo central ( $\uparrow)$, que tinha por foco visual a igreja. Esta via dava acesso à praça (1), que era o centro geográfico e cultural da redução, regendo sua vida urbana. Tinha cerca de 130m de lado e nela ocorriam os autos-de-fé. Sua posição central lembra o espaço cerimonial das aldeias e também das cidades europeias, de modo que Snihur (2007, p. 94) salienta que ela "caracteriza o senso de comunidade, de pertencer ao lugar. [...] é um espaço vazio de elementos, mas um vazio cujo volume supera tudo quanto existe no povoado, inclusive o templo, e com tamanha força de atração que é capaz de dar coesão e unidade à vida na redução". Ele também acredita que o posicionamento das casas ao redor da praça central está relacionado aos conceitos de comunidade e solidariedade.

Snihur (2007, p. 95) afirma que havia uma divisão entre os espaços espaço sacral e o civil, realizada pela rua que passava em frente à igreja e ladeava a praça, e que era mais larga que as demais por sua função. De um dos lados desta divisão, no eixo central da praça, era construída a igreja (2), que era sempre o prédio mais importante e imponente da redução. Abrigava as liturgias que eram realizadas em língua nativa para melhorar a aproximação com a população.

Com 30 metros de largura e até 60 metros de comprimento, a igreja era um símbolo da 


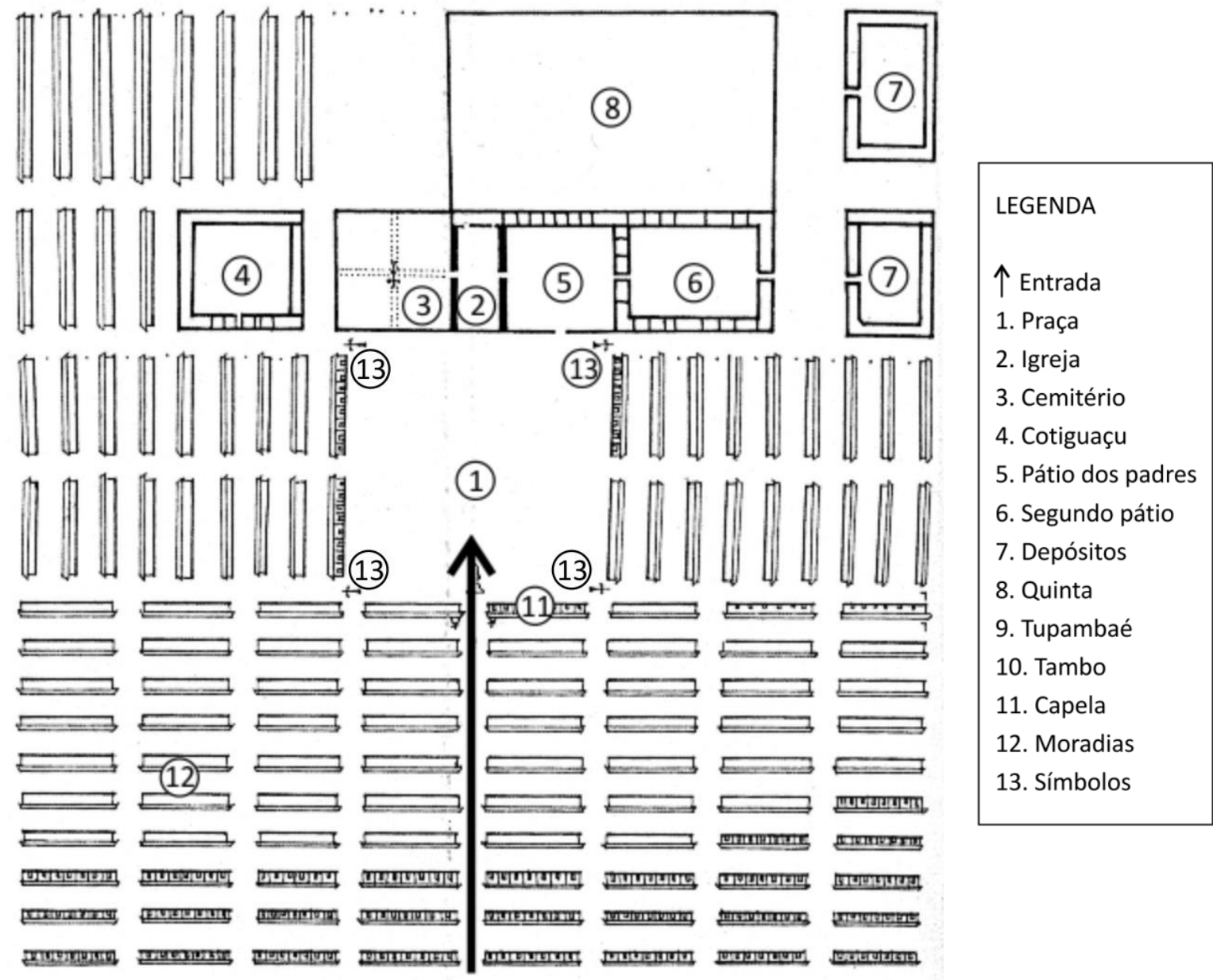

Figura 6. Representação da implantação de uma redução jesuítica. Fontes: MAEDER; GUTIÉRREZ, 2010, p. 45 e 47, numeração e legenda nossas. 
autoridade dos padres e do poder da religião em todos os âmbitos da sociedade missioneira. As principais construções da redução estavam posicionadas junto à igreja, de modo a facilitar sua administração e fiscalização por parte dos padres. De um dos lados ficava o cemitério (3), uma área dividida em quadrantes por calçadas ladeadas de árvores. De acordo com Maeder e Gutiérrez (2010), em cada um dos quadrantes eram enterrados determinados indivíduos, separados por idade e gênero: meninos, meninas, adultos e adultas.

Já o cotiguaçu ("casa grande" em tupi) (4) foi uma edificação que, [...] no desenrolar da experiência, [assumiu] uma função específica de gênero, indício claro da mobilidade funcional recorrente a boa parte dos prédios missionais. [...] (BAPTISTA, 2009a, p. 82).

Abrigava meninas e mulheres desamparadas, órfãs e viúvas em uma edificação cercada por muros, formando um pátio interno para a qual se abriam os cômodos. Existia apenas uma porta para o exterior, com duas chaves diferentes em poder de duas senhoras de avançada idade e de confiança dos padres, uma delas ficava posicionada no interior da edificação e a outra no exterior. Segundo Venturini (2009, p. 40), as duas chaves da porta do cotiguaçu precisavam ser utilizadas ao mesmo tempo para abri-la. Eram poucos os motivos pelos quais as internas podiam sair (ir à missa para orar ou ao tanque para lavar a roupa; ou ir buscar lenha, água e alimentos) e sempre eram vigiadas. O funcionamento desse prédio era parecido com o de um reformatório-escola, onde elas aprendiam trabalhos manuais e as regras do bom viver, por isso seu posicionamento sempre afastado das casas: possuía função de correção dos hábitos das mulheres que ali viviam. Este é um grande exemplo de como a arquitetura e o urbanismo das Reduções moldaram-se às necessidades encontradas no decorrer do convívio dos padres com os habitantes.

Do outro lado da igreja, ficavam posicionadas estruturas relacionadas aos trabalhos dos 


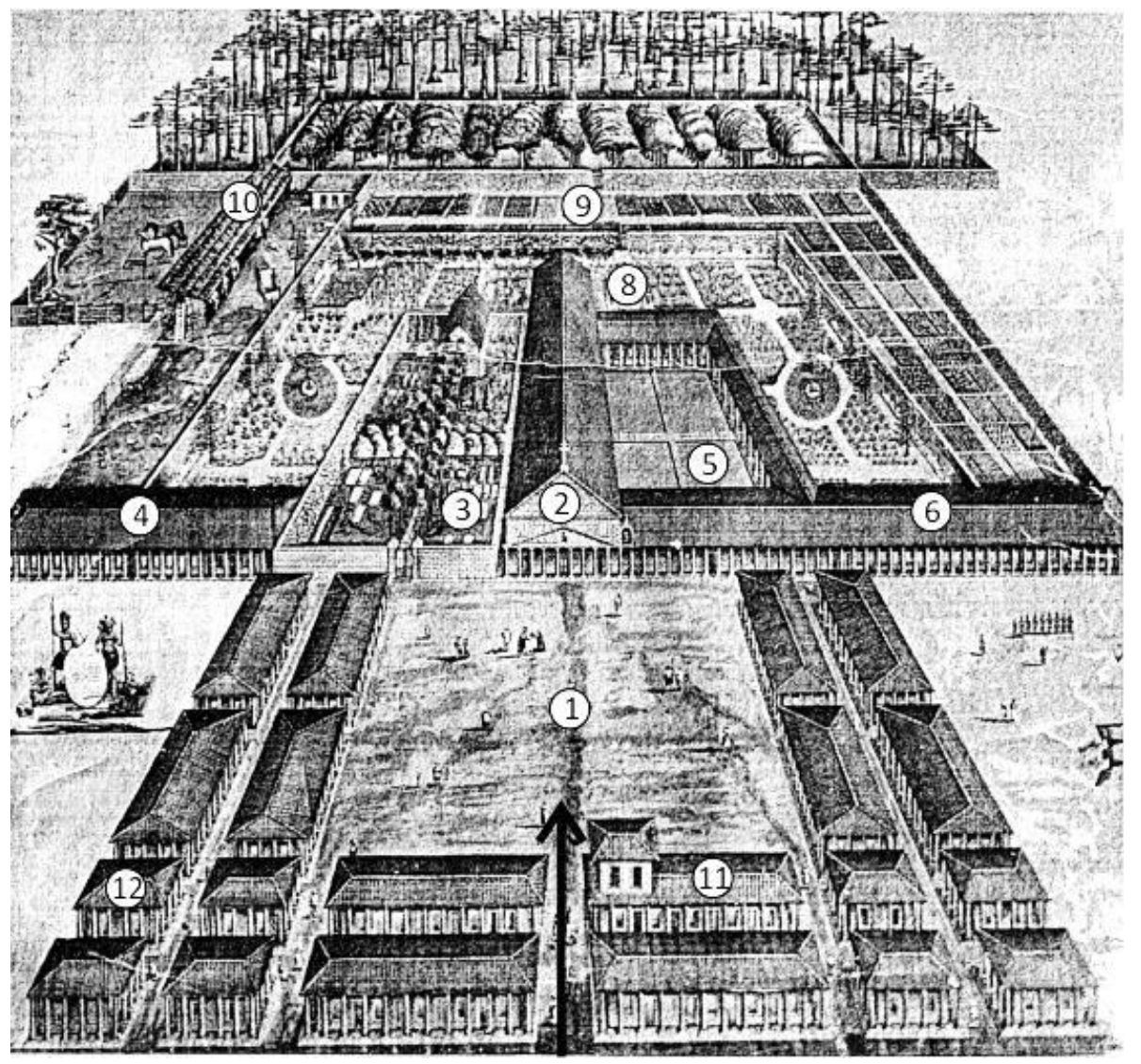

LEGENDA
Entrada
1. Praça
2. Igreja
3. Cemitério
4. Cotiguaçu
5. Pátio dos padres
6. Segundo pátio
7. Depósitos
8. Quinta
9. Tupambaé
10. Tambo
11. Capela
12. Moradias
13. Símbolos

Figura 7. "Vista a voo de pássaro de uma missão jesuítica". Fontes: FURLONG, 1962, p. 189, numeração e legenda nossas. 
padres (Figuras 6 e 7). O pátio da casa dos padres (5) dava acesso a diversos cômodos com várias funções. Logo ao fundo da igreja havia a sacristia e ao redor do pátio estavam alocados os aposentos dos padres, o refeitório, os escritórios, o colégio, entre outros. Também era o local onde estava localizado o relógio de sol, que regia a vida na redução, marcando os horários de todas as atividades, que eram anunciadas com o badalar dos sinos que ficavam no campanário, presente neste mesmo pátio. No segundo pátio (6), geralmente localizado ao lado deste primeiro, ficavam as oficinas, armazéns e arsenais, que envolviam a ferraria, a marcenaria, o açougue, o moinho, a fábrica de rosários e a de carroças (SNIHUR, 2007, p. 98).

No modelo de Maeder e Gutiérrez (2010), são marcadas duas construções como depósitos de uso comum (7). Já atrás da igreja e da sacristia, ficava a quinta dos padres (8), que abrigava o pomar, a horta e o jardim destinado ao uso pessoal dos jesuítas, pois eles "também deveriam buscar o sustento próprio, pelo menos no início da redução. [...] podia ter até três hectares de área, servia também para experiências de aclimatação de sementes novas" (SIMON, 2010, p. 94). De acordo com Snihur (2007, p. 98), este local era rodeado por muros altos e também possuía a função de enriquecer a alimentação dos doentes.

Fora deste complexo aldeamento-templo ficava o tupambaé (9), espaço comunitário de plantio onde os índios trabalhavam dois ou três dias por semana para sustento da população da missão. Segundo o arquiteto brasileiro Günter Weimer (1999, p. 23-24),

Nos demais dias, os índios trabalhavam em terras particulares, chamadas amambaé [que se localizavam em local distante do núcleo construído], da qual deveriam extrair o seu sustento. Esta atividade sempre foi um ponto de atrito com os padres posto que, segundo a tradição indígena, agricultura era coisa de mulher e aos homens competia caçar e pescar.

Ainda havia uma hospedagem para os viajantes, chamada tambo (que esta pesquisa acredita 
estar localizada em (10), que consistia de uma espécie de albergue junto ao qual havia um curral para os animais, onde, segundo Teixeira (1990, p. 15), havia tempo máximo de permanência para os viajantes.

Na capela mortuária (11) eram velados os adultos que faleciam. Além disso, havia uma edificação posicionada junto à praça chamada cabildo, mas sua localização não é unânime entre os autores consultados. De acordo com Simon (2010, p. 94), ele estava "situado no outro lado da praça defronte à igreja", onde de acordo com o modelo apresentado por Maeder e Gutiérrez na Figura 6 estaria a capela mortuária. Portanto, não foi possível indicar sua localização na figura. Esta edificação abrigava o governo civil das Reduções representado pelos caciques e por outros membros com cargos ditos administrativos. Segundo Venturini (2009, p. 43-44), embora os membros do cabildo auxiliassem na administração do povoado, a autoridade religiosa e civil estava concentrada nas imagens dos padres, um para cada função para cada missão. De acordo com Snihur (2007, p. 101), a edificação abrigava cômodos grandes para as reuniões e continha "a mesa dos membros do Cabido, o retrato do Rei, os estandartes reais, o arquivo com documentos, os baús em que as insígnias e as galas dos membros do Cabido eram guardadas, e um pequeno altar dentro da parede onde geralmente havia uma imagem da Virgem Maria ou do Santo Padroeiro da redução".

Havia ainda as casas dos indígenas (12), que ocupavam grande parte do espaço urbano das Reduções. Cada uma delas ocupava o equivalente a um quarteirão e abrigava os membros de um cacicado (VENTURINI, 2009, p.37), sendo elevadas em relação ao nível da rua para evitar a entrada da água da chuva nas moradias. Segundo Snihur (2007, p. 101), "Os caciques e suas famílias ocupavam casas mais próximas da praça" e os cômodos familiares abrigavam todas as funções do dia-a-dia: "de dia [funcionava] como sala de estar e de diversas atividades, e de noite 
as redes eram penduradas para dormir" (SNIHUR, 2007, p. 101). A divisão das famílias foi criada para evitar a aglomeração de muitas pessoas no mesmo recinto (considerada promiscuidade pelos padres, mas que nas aldeias indígenas era fruto da estrutura social formada por famílias extensas, constituídas por pais, filhos e todos os descendentes, que moravam juntos em uma grande oca sem divisão interna). Segundo Baptista (2009a, p. 99), a visão que os padres tiveram das aldeias indígenas em meio à mata era a seguinte:

Em virtude dos extensos laços de parentesco, são tantos que vivem nessas casas, além de um entra e sai desvairado, que se torna difícil aos padres identificar quem é quem. Naturalmente, esse conglomerado de gente propicia a "acostumada ocasião de pecado", especialmente no que se refere aos "amancebados" [...]. Configurando-se em aldeias, em grandes casas comunais ou até mesmo em raros ranchos de núcleos familiares pequenos, o modo de vida Guarani aparece à vista dos primeiros missionários como um verdadeiro escândalo à civilização.

Nessa descrição citada por Baptista, percebe-se a visão de mundo ocidental pré-concebida dos jesuítas atuando sobre seu entendimento das relações sociais indígenas. Essa foi uma das grandes preocupações dos padres, para quem o convívio entre homens e mulheres na mesma casa era visto como pecado. Tentaram impedir tais atos criando os cômodos para cada família de pais e filhos, e ao mesmo tempo tentaram manter uma identidade tribal ao inseri-lo dentro de grandes edificações únicas.

Retomando a análise das Figuras 6 e 7, percebe-se que "A religiosidade estava presente em todos os locais, com a colocação de cruzes e símbolos sacros (13) em capelas e em vários pontos da povoação, assim como na praça e nos campos" (TEIXEIRA, 1999, p. 15). Segundo Baptista (2009a, p. 175-176), 
os nativos parecem atribuir [às cruzes] um caráter mágico e político. De fato, a primeira ação dos jesuítas no ato da fundação de cada povoação se dá mediante a instalação de grandes cruzes, não raro sendo esse ato solicitado por caciques desejosos por demonstrar aos colonos espanhóis que ali estão sob os cuidados da fé católica [...].

[...] [a cruz jesuítica] guarda, defende, ampara os que se põem a trabalhar em sua sombra. [...] passa a se configurar como um importante objeto com poderes curativos, [...] deixa claro aos colonos que naquela seara se encontram cristãos sob a ordem missionaria [...]. A cruz, enfim, demarca as fronteiras entre índios missionais e infiéis.

Além das estruturas edificadas, existiam duas áreas muito importantes, que estavam relacionadas com a produção agrícola e, consequentemente, o sistema de autogestão das Missões Jesuíticas: o amambaé (em Tupi, “o que pertence ao indivíduo") e o tupambaé (“o que pertence a Deus"). Segundo Snihur (2007, p. 123),

[...] amambaé se referia à pequena porção de terreno agrícola outorgado a cada família indígena para que o cultivasse em seu próprio benefício, trabalhando nele durante determinados dias da semana. Em compensação, o tupambaé eram as terras pertencentes à comunidade, onde o trabalho e a produção eram comunitários. O tupambaé correspondia as fazendas, no caso da criação de gado, e os plantios, no caso da produção agrícola. Ao contrário dos terrenos do amambaé, que eram pequenos e estavam localizados nas imediações do povoado, as terras do tupambaé eram muito amplas e estavam situadas, em alguns casos, a uma distância considerável dos povoados. Também fazia parte do tupambaé o trabalho nas oficinas, nas pedreiras, nas fábricas de telhas e toda a produção que estivesse destinada à comunidade.

Neste sistema, a autogestão era uma realidade, de modo que cada povoado buscava o auto sustento e, normalmente, se destacava na produção daquilo que lhe era mais favorável de acordo com os recursos presentes em seu local de implantação e as habilidades desenvolvidas pela população sob a orientação dos conhecimentos específicos dos jesuítas responsáveis. Snihur (2007) ainda ressalta que, se analisarmos a geografia da região em que foram implantadas as 
Missões, dois tipos de produção dividiam os povoados em meridionais (nos campos livres de montes ou florestas) e setentrionais (na região entre o campo e a floresta). Segundo o autor,

Os povoados de Santo Tomé, La Cruz, Yapeyú, San Miguel, San Borja, San Lorenzo, San Juan Bautista, Santo Ángel, San Luís e San Nicolás, assentados todos na zona meridional ou de campo, especializaram-se na produção de gado e na exploração das fazendas. Estes povoados garantiam o fornecimento de carne e couros a todas as reduções, além dos excedentes necessários para serem comercializados nos ofícios de Santa Fé ou Buenos Aires.

Os povoados assentados nas missões setentrionais foram principalmente agrícolas. Os plantios adquiriram renome em povoados como Santa Maria de Fé, Santiago, San Cosme y Damián, Jesus, Trinidad, Itapua, Santa Rosa, San Javier, San Ignácio Miná, Nossa Senhora de Loreto, Corpus, Candelária e Santa Ana.

Em compensação, outras reduções das missões setentrionais como San José, Apóstoles, Santa Maria la Mayor, Concepción e Mártires, localizadas exatamente na área de transição campo-floresta, desenvolveram um modelo em que se misturavam a produção agrícola e a criação de gado, a partir do estabelecimento de fazendas na bacia superior do rio Aguapeí.

Por outro lado, a produção de erva foi uma especialidade das reduções de Nossa Senhora de Loreto, Corpus e San Javier, povoados que contavam com importantes plantios de erva, tanto naturais como implantados (SNIHUR, 2007, p. 126).

Esta estrutura unitária estava interligada com as demais através de uma extensa rede de caminhos terrestres ou fluviais, possibilitando o aspecto de solidariedade mútua tão característico das Missões Jesuíticas. Por isso, de acordo com Venturini (2009, p. 43), "Quando a produção de um povo tinha problemas devido a fatores naturais adversos, outro povo o socorria [...]". Portanto, os excedentes da unidade eram trocados dentro do sistema e as sobras desse processo eram comercializadas. Da mesma forma, se não houvesse produção suficiente de algum item, este era solicitado aos ofícios de Santa Fé ou Buenos Aires. 
Comparando-se as duas implantações (Figuras 6 e 7), percebe-se que cada redução moldou o traçado urbano e o posicionamento das construções de acordo com suas necessidades e possibilidades do local onde foram implantadas. De acordo com Snihur (2007, p. 89),

Estas alterações na disposição de alguns elementos característicos urbanos não se deviam a uma tentativa de mudar o modelo, mas a de adequá-lo às características ou topografia do terreno em que o povoado estava instalado. [...]

[...] Além da existência de uma evolução no que diz respeito a técnicas de construção e à geração das mesmas configurações, o fenômeno urbano e arquitetônico nas reduções foi uma resposta a uma realidade cultural e ambiental definida, o produto do encontro de duas culturas - a guarani e hispânica - e de um ecossistema particular que também atuou como um fator condicionador.

Portanto, cada uma das Missões possuía sua especificidade, de acordo com a formação dos padres que estavam à frente da missão (CUSTÓDIO, 2014). Por exemplo, a imprensa de Nuestra Señora de Loreto e o observatório astronômico San Cosme Y Damián. Apesar disso, todas elas partiram de um modelo inicial e, por isso, apresentam mais semelhanças do que diferenças.

Sobre a arquitetura missioneira, o arquiteto brasileiro Lucio Costa ${ }^{32}$ (2010 [1941], p. 4) afirma

O programa das construções jesuíticas era relativamente simples. Pode ser dividido em três partes, correspondendo cada uma destas a uma determinada utilização: para o culto, a igreja com o coro e a sacristia; para o trabalho, as aulas e oficinas; para residência, os "cubículos", a enfermaria e mais dependências de serviço, além da "cerca", com horta e pomar.

De acordo com o arquiteto brasileiro Luciano Patetta (2001, p. 390),

[...] os Jesuítas nunca tiveram na arquitetura "um estilo" propriamente dito, nem existem documentos na Ordem em que se faça referência a um estilo,

\footnotetext{
${ }^{32}$ Lucio Costa foi um importante arquiteto brasileiro modernista, que realizou levantamentos a serviço do IPHAN na década de1940.
} 
desejável ou a ser adoptado ou a impor; que, pelo contrário, os Jesuítas foram uma das Ordens mais "flexíveis", tendo escolhido de se adaptar às situações históricas, às evoluções culturais e às condições da sociedade.

Snihur (2007, p. 85) concorda que a arquitetura missioneira foi um processo de interação entre as técnicas construtivas europeias e indígenas. E a mesma afirmação é correta para as demais artes, sobre as quais Costa (2010 [1941], p. 3) afirma: "as manifestações de arte dos jesuítas apresentam formas diversas, de acordo com as conveniências e recursos locais e com as características de estilo próprias de cada período". Já o ex-Diretor do Museu de Arte do Rio Grande do Sul - MARGS, Fabio Coutinho (2000), salienta que as obras artísticas missioneiras podem ter sido realizadas por vários colaboradores. O que é comprovado pelas igrejas jesuíticas, onde "atingiram-se alguns dos êxitos mais brilhantes de síntese das três artes: arquitetura, pintura e escultura" (PATETTA, 2001, p. 393)

Além disso, as edificações nas Reduções passaram por três etapas executivas, influenciadas pela disponibilidade de material e pelas técnicas construtivas (COSTA, 2010 [1941]; CUSTÓDIO, 2000a). Durante a implantação das Reduções jesuíticas foram construídas "choças de madeira, palha, esteiras e barro, utilizado nas taipas de mão" (CUSTÓDIO, 2000a, s.p.), das quais não se tem registros em imagem. Com o tempo, estas edificações iniciais eram substituídas por "estruturas independentes de madeira, com paredes de adobe, tijolos cerâmicos ou pedra, assentados com barro, com coberturas de telhas" (CUSTÓDIO, 2000a, s.p.), e eram chamadas de edificações provisórias. Neste caso, "quatro carreiras paralelas de pilares alinhados entre si, que sustentam caibros laterais e tesouras de linhas altas, centrais. Os pilares possuem bases quadrangulares ou cilíndricas, às vezes entalhados. As paredes externas de pedra ou adobe, os envolvem, possuindo o dobro de sua espessura" (CUSTÓDIO, 2000a, s.p.) 

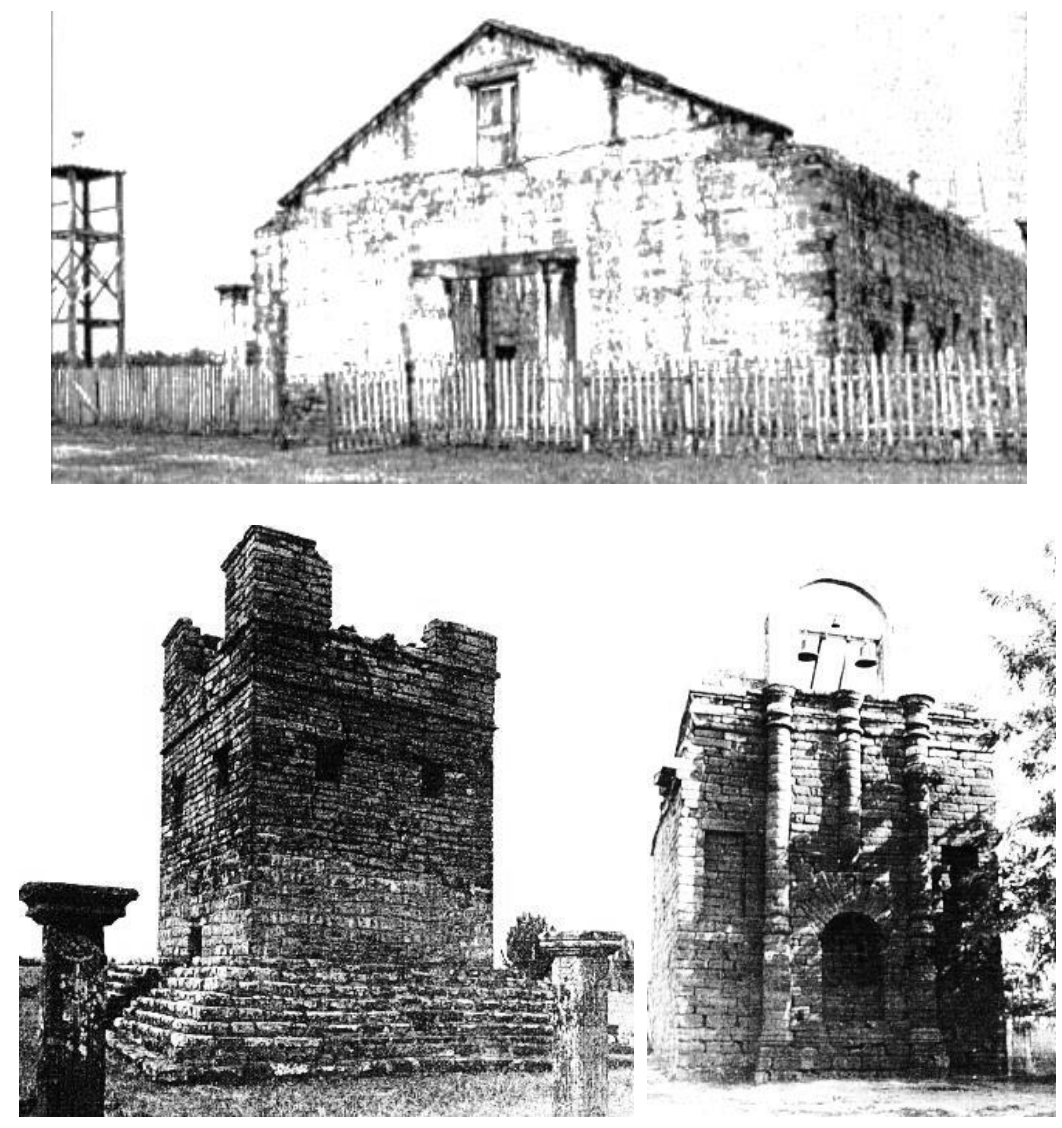

Figura 8. Igreja provisória de San Cosme y Damián, exemplo da Fase 2 - já destruída; Campanários de Trinidad e de Santa Rosa.

Fonte: GUTIÉRREZ, 1987, p. 20, 53 e 36. 
Um exemplo deste tipo de construção é a igreja provisória da missão de San Cosme e Damián, mostrada na Figura 8, na página ao lado, onde se vê à esquerda parte do campanário; que "Na maioria dos povoados, era uma estrutura independente do templo, construída com forquilhas de madeira sobre uma base de pedras entalhadas, colocada no pátio da Residência" (SNIHUR, 2007, p. 97). Os campanários eram muitas vezes estruturas independentes do templo mesmo na última fase construtiva (Figura 8).

Segundo instruções de Roma, as edificações provisórias da segunda fase

foram, pois, substituídas, logo que as circunstâncias o permitiram e muitas vezes ainda no primeiro século, por construções já de caráter definitivo, de taipa de pilão ou de pedra e cal, dependendo a preferência dos recursos e das conveniências locais. As duas técnicas eram empregadas contemporaneamente. Onde houvesse bom barro e pedra e cal fossem difíceis de obter, recorria-se à taipa de pilão (COSTA, 2010 [1941], p. 4).

A última etapa construtiva compreende construções com "estruturas portantes em pedra, [...] [com] alguns elementos arquitetônicos construtivos mais complexos, como arcos em pedra e abóbadas de ladrilhos ou madeira. Nesta fase foi descoberta a cal na região" (CUSTÓDIO, 2000a, s.p.). As paredes dessas construções possuíam maior espessura, realizadas em pedra de cantaria nas duas faces, com preenchimento interno de pedras irregulares e barro. Alguns dos materiais utilizados foram: a argila vermelha para tijolos, pisos e telhas; a tabatinga, um barro esbranquiçado, para pintar as construções; o arenito rosa para cantaria; a pedra itacurú para fundações; o ferro para equipamentos, sinos e ferragens; o cedro para construções e esculturas; e o couro para correarias e mobiliário (SNIHUR, 2007, p. 158). As técnicas construtivas europeias foram ensinadas à mão-de-obra da região das Missões e adaptadas aos materiais disponíveis.

Contudo, essa interação não seria possível sem os profissionais polivalentes vindos da 

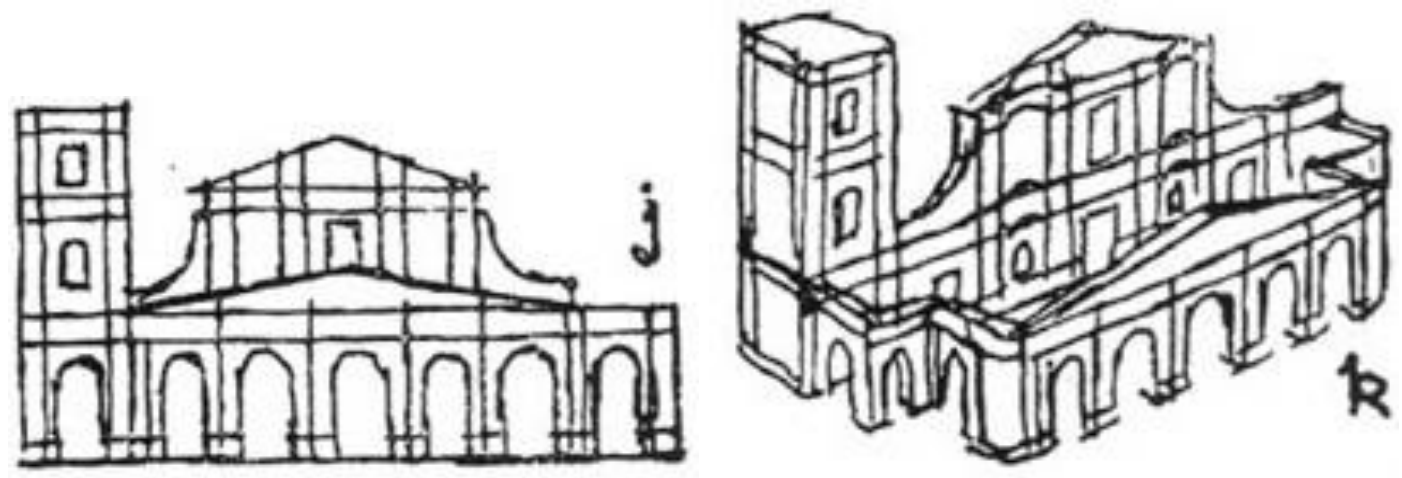

Figura 9. Desenho de Lucio Costa da igreja de São Miguel com o pórtico.

Fonte: COSTA, 2010 [1941], p. 51.
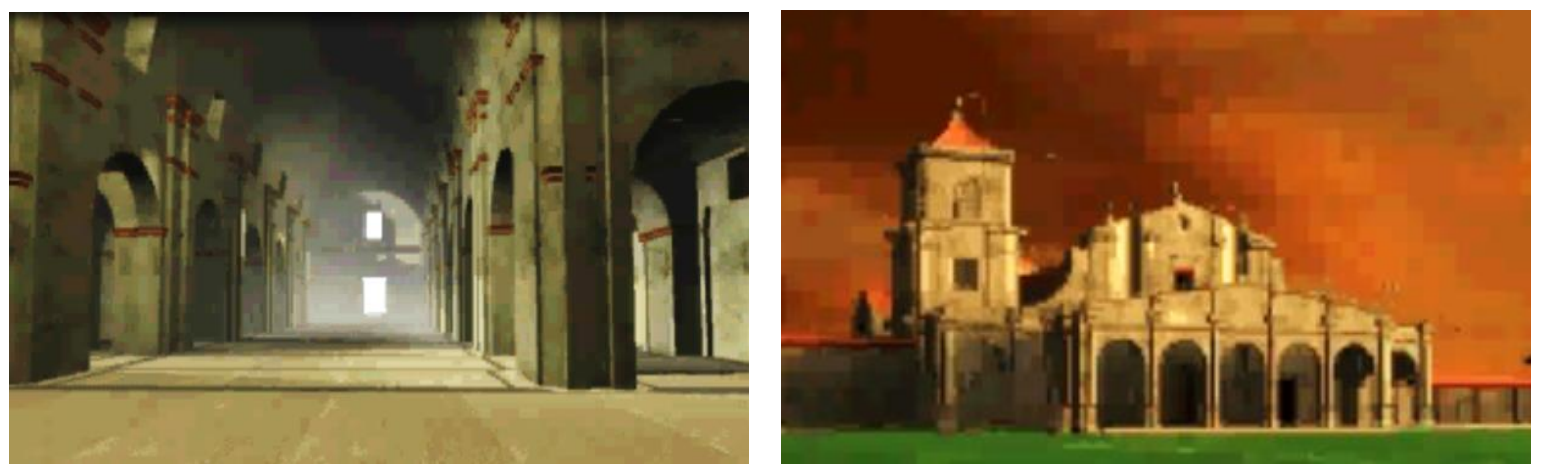

Figura 10. Arcos internos que separam a nave central das laterais e torre da igreja de São Miguel em reconstituição virtual. Fonte: UNISINOS; IPHAN, 1990, CD-ROM. 
Europa, que trouxeram o conhecimento necessário para a prática dos ofícios. De acordo com Custódio (2000a, s.p.), alguns jesuítas importantes vieram à América no século XVII, tais como os italianos José Brasanelli e Angel Camilo Petragrasa e o austríaco Antônio Sepp. Já no século XVIII, veio o italiano Gian Baptista Prímoli, arquiteto que realizou as obras das Igrejas de São Miguel Arcanjo e de Trinidad, dentre outras edificações em várias Reduções. Para entender as relações entre a arquitetura missioneira e a europeia, é interessante analisar a fachada da igreja de São Miguel (Figuras 9 e 10, na página ao lado), por seu melhor estado de conservação. Dentro da tipologia final adotada para as igrejas missioneiras "As naves laterais são separadas da central por conjuntos de colunas ou por maciços que sustentam arcos de pedra ou tijolos. [...] A maior parte das igrejas missioneiras possuía apenas uma torre, que se localizava do lado oposto ao batistério" (CUSTÓDIO, 2000a, s.p.).

Embora não houvesse uma tipologia arquitetônica a ser adotada (PATETTA, 2001), assim como várias outras igrejas missioneiras, estima-se que a igreja de São Miguel tenha sido inspirada na igreja de Gesú, em Roma, cujo projeto inicial foi de autoria de Vignola (Figura 11, na próxima página). A igreja de Gesú foi a primeira da Companhia de Jesus e serviu de inspiração para as demais construídas nos países onde os jesuítas atuavam. Se forem comparadas as fachadas das igrejas de Gesú, em Roma, e de São Miguel em sua forma original sem o pórtico, percebe-se que há semelhança em seus elementos de composição embora a de São Miguel possua menos rebuscamento. $\mathrm{O}$ que provavelmente se deve às condições de materiais e mão-de-obra de cada lugar, fazendo com que a interação entre as duas culturas construtivas (a indígena e a europeia) fosse necessária e possibilitando sua sobreposição, ou seja, uma hibridização cultural caracterizada pela emergência de algo novo. A semelhança entre as duas fachadas talvez se deva também à nacionalidade italiana de Gian Baptista Prímoli, que possuía influência das diversas 

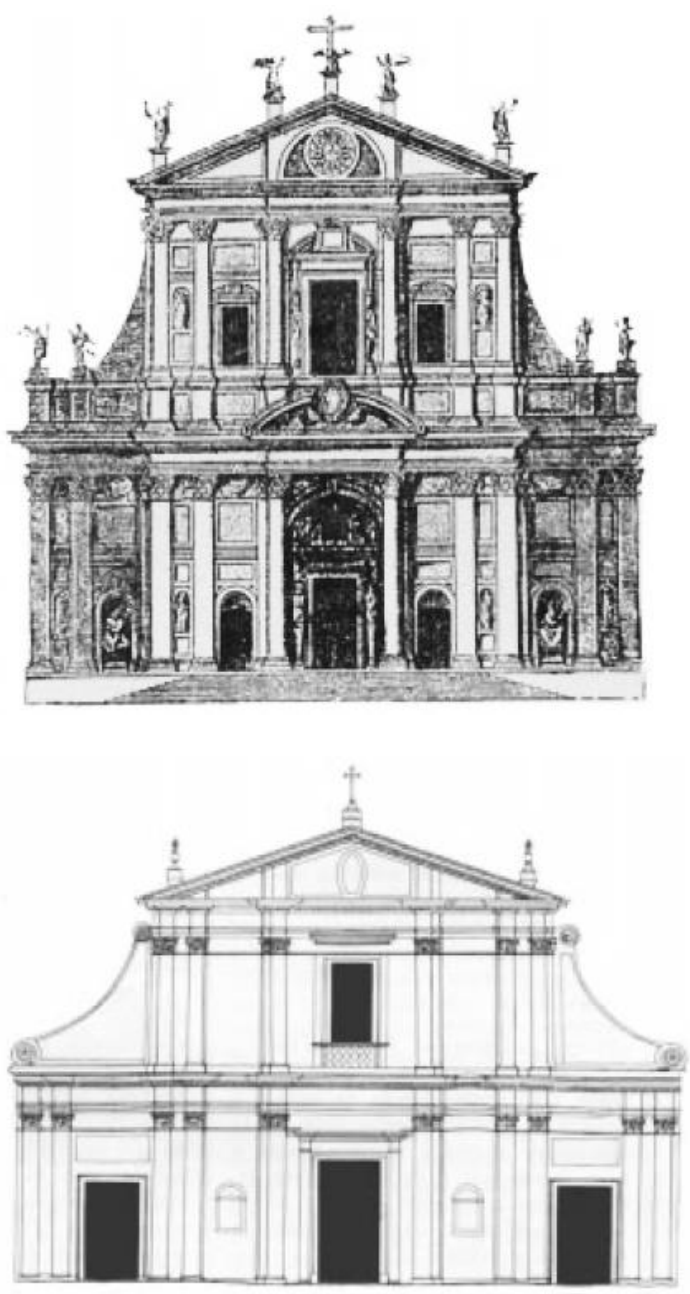

Figura 11. Igreja de Gesú, em Roma, e reconstituição da Igreja de São Miguel Arcanjo sem o pórtico, no Rio Grande do Sul. Fonte: CUSTÓDIO, 2002a, p. 177. 
tendências europeias e provavelmente conhecia a igreja de Gesú. Portanto, a tipologia missioneira constituiu uma mescla das técnicas europeias, da habilidade local e dos materiais encontrados nas regiões onde foi construída. Dessa forma, sendo mais um dos aspectos sociais em que ocorreu a interação entre os dois modos de vida envolvidos nessa experiência tão fascinante.

\subsection{Conversação entre duas culturas: Arte e Sociedade}

A relação entre jesuítas e indígenas era incentivada por três motivos principais: 1 . A proteção oferecida contra os regimes econômicos impostos pelas Coroas Portuguesa e Espanhola (que incluíam os indígenas na sociedade como mão-de-obra para trabalhos forçados e cobrando impostos); 2. A abundância de alimentos produzidos sob o regime jesuítico; e 3. A promessa dos jesuítas de que "a Terra sem Males não estava aqui, mas noutra dimensão, no céu, e, para alcançá-la, deviam mudar de vida e crer num Deus, Único e Verdadeiro, Jesus Cristo" (VENTURINI, 2009, p. 38-39). Contudo, nem todas as tribos cederam a essa perspectiva. "Se para alguns grupos indígenas a sobrevivência estava na aliança com os europeus, para outros ela podia estar no enfrentamento e na construção de uma imagem terrificante que tinha o efeito de despertar o medo nos inimigos e mantê-los distantes, pelo menos por um certo tempo" (MONTEIRO apud BAPTISTA, 2009a, p. 127)

Baptista (2009a) acrescenta que, durante sua aproximação com as tribos, os jesuítas interpretaram erroneamente a relação hierárquica existente. Segundo ele, tendo como exemplo a hierarquia europeia, vislumbraram os caciques como soberanos de um estado monárquico por 
reunirem uma considerável população sob sua influência. Por isso, os líderes foram seu ponto focal de atuação no arrebanhamento de novos fieis.

É importante salientar que, por uma questão reducionista, a população missioneira é denominada como homogênea, sendo composta por indivíduos das tribos do tronco linguístico tupi-guarani. Contudo, como afirma Baptista (2009a, p. 107),

os povoados missionais são compostos por uma diversidade de grupos étnicos significativos para a geração, desenvolvimento e complexidade daquela experiência $^{33}$. Impõe-se, assim, um importante princípio de abordagem documental: o reconhecimento da diversidade como característica fundamental daquele processo em conjunto à avaliação de significativas transformações de identificação étnica oriundas do contexto.

Após o estabelecimento dos aldeamentos, novos habitantes eram arrebanhados pela incursão pacífica de habitantes das Missões, que atuavam como caçadores do Senhor ou na forma violenta de cativos de guerra. Moradores de diversas etnias eram designados para tais serviços porque a diversidade facilitava a comunicação com os grupos étnicos não Guarani.

De acordo com o advogado brasileiro Salvador Cabral et al (2004, p. 37), para o pleno funcionamento das Missões, os jesuítas respeitaram aspectos da cultura dos habitantes originais do continente, como a língua, a estrutura organizacional das instituições e a organização cívica. Diretrizes que foram testadas pelo padre Anchieta no Brasil e posteriormente utilizadas nas Missões Jesuíticas nos demais países da Província do Paraguai (CUSTÓDIO, 2014). Além disso, Cabral et al (2004, p. 42, tradução nossa ${ }^{34}$ ) comenta que muitas expressões culturais dos guarani

\footnotetext{
${ }^{33}$ Entre os outros povos encontrados nas missões, Baptista (2009a) cita os Pampianos e os Jês.

${ }^{34}$ Do original em inglês: "[...] discovered new possibilities within the context of the Jesuit Missions" (CABRAL et al, 2004, p. 42).
} 
"encontraram novas possibilidades dentro do contexto das Missões Jesuíticas". Dessa forma, nas Missões ocorreu um processo único de "recolocações de crenças e práticas dos envolvidos. Afinal, tanto para padres quanto para nativos, o contexto que enfrentavam só podia levar a uma única certeza: o mundo anterior já não existia, e o novo que se construía, exigia profundas transformações" (BAPTISTA, 2009b, p. 19).

Através de aproximações e distanciamentos, as culturas europeia e indígena encontraram seu equilíbrio na hibridização derivada da circularidade entre elas. Essa circularidade é descrita pelo ciberneticista inglês Ranulph Glanville (2004, p. 1380, tradução nossa ${ }^{35}$ ) como um momento, "em que o observador [...] observa o que está acontecendo em algum sistema e atua sobre aquele sistema". O que pode ser comparado com o conceito de retroação de Morin (2005 [1970]) e ocorreu em muitos aspectos da vida social das Missões Jesuíticas, "constituindo-se nesse processo de convergência que a transforma numa 'cultura híbrida' ou 'mestiça'” (FACHIN, 2010, p. 16). Contudo, este processo não foi pacífico, ocorreram muitas crises entre jesuítas e indígenas e, principalmente, muitas negociações, das quais emergiu a cultura missioneira, mundialmente conhecida como uma construção histórica única. Isso ocorreu porque

após alguns anos de experiência com os índios brasileiros -, [os jesuítas tiveram a percepção] de que estes não seriam propriamente tábula rasa, como era esperado; pelo contrário, eram portadores de uma cultura e de um ethos muito diferentes, e às vezes radicalmente opostos à cultura e aos valores religiosos e morais dos europeus, conforme é documentado pela correspondência jesuítica escrita do Brasil ao longo do século XVI (MASSIMI, 2004, p.29).

Tais crises envolveram os mais variados aspectos da sociedade, desde as divindades e santos

\footnotetext{
${ }^{35}$ Do original em inglês: "[...] in which the observer [...] observes what is happening in some system and acts on that system” (GLANVILLE, 2004, p. 1380).
} 
até a relação com o trabalho e a produção de alimentos, devido à diversidade tão marcante entre as duas culturas originais. Segundo Baptista (2009a, p. 192),

as construções de espaços missionais e suas sociedades levantam importantes problemas. [...] a tensão entre a cultura material/técnicas ocidentais e as motivações e conteúdos atribuídos, assim como o exercício de vivências longínquas aos olhos dos padres [...] a sociedade missional fez de suas estruturas um campo de relações em torno de importantes instituições.

Portanto, as características socioculturais das Missões Jesuíticas se conformaram pela interação entre os indivíduos que a compuseram, no contexto histórico específico em que se desenrolaram. De modo que vários aspectos da vivência missional foram moldados através desta experiência. Na religião, os jesuítas utilizaram o idioma tupi nas orações e liturgias, e adotaram alguns nomes de deuses guarani para facilitar a apreensão da nova cultura. Também ocorreram correlações de divindades, por exemplo, Nossa Senhora recebeu o nome de Tupã Sy ou Ñande Sy nos catecismos das Missões (BAPTISTA, 2009a, p. 178). Por outro lado, também foi necessária a adoção de denominações espanholas para o que não existia na cultura guarani, como a palavra camisa (BAPTISTA, 2009a, p. 148).

A concepção do pós-morte nas duas culturas também era bastante diferente e se mesclava a suas visões do trabalho. Conforme Baptista (2009a, p. 61),

enquanto na tradição cristã os ofícios mecânicos possuem forte carga de sofrimentos, a produção entre os Guarani é um recomendável meio de elevação espiritual e devoção às entidades mais nobres. [...] Nesse sentido, Schaden admira-se por não haver entre os Guarani a espera de uma vida ociosa no alémmorte, permanecendo convictos de lotes de terra a eles destinados pelos deuses.

Dessa forma, para os guarani o trabalho era enaltecedor do homem, de modo que o realizavam com a perfeição de que eram capazes, ao contrário da cultura europeia que 
considerava que "a vida era uma tarefa, uma sofrida obrigação, que a todos condenava ao trabalho e tudo subordinava ao lucro" (RIBEIRO, 1995, p. 47).

O trabalho [para os Guarani] era apenas para prover o sustento imediato, pescavam ou caçavam quando tinham fome, buscavam água se tinham sede, derrubavam a árvore se precisavam fazer uma canoa. O maior prazer dos guaranis era permanecer sentado num banquinho ou numa rede conversando com amigos (FLORES, 1997 apud BAPTISTA, 2009b, p. 32).

O que causou um grande impasse entre as duas culturas, pois os jesuítas estabeleceram que o indígena deveria trabalhar a semana inteira, dividido entre as terras comunais (tupambaé) e as particulares (amambaé). O que era motivado pela cultura europeia de acumulação de excedentes para o sustento da sociedade em épocas de baixa produção agrícola. Os objetivos divergiam: enquanto os jesuítas buscavam um aumento na produção de alimentos, os nativos gostariam de manter seus hábitos de dependência da natureza.

O contraste também ocorreu na organização da sociedade, pois os indígenas viviam em famílias-extensas, onde cada um possuía seu papel na comunidade e a produção e o consumo de bens era guiada pela lógica da reciprocidade (José Otávio Cafesto de Souza, 2002 apud BAPTISTA, 2009a, p. 22). Tal sociedade "estava baseada na liderança do cacique e no conselho de anciãos. Os caciques mantinham suas lideranças pela razão e principalmente pela redistribuição constante de bens e alimentos. Deviam ser fortes e generosos" (TEIXEIRA, 1990, p. 14). Essa autoridade social dos caciques foi adaptada nas Missões Jesuíticas com a criação dos cabildos. Enquanto alguns acreditam que eles realmente exerciam a administração da vida civil da redução em que viviam, outros afirmam que esta foi uma designação mais filosófica do que prática, para que o respeito dedicado à figura do cacique não se esvaísse, mas o poder de decisão permanecia nas mãos dos dois padres que coordenavam a missão, pois eles sempre deveriam ser consultados e suas 
opiniões eram decisivas. Segundo Snihur (2007, p. 139), “Um deles, chamado de 'cura', estava encarregado dos assuntos espirituais ou relativos à evangelização, e o outro, chamado de 'companheiro', ocupava-se dos assuntos temporais tais como a administração, a organização do trabalho e o controle das atividades cotidianas".

Se em relação à organização política ocorreram muitas mudanças, uma característica do modo de vida tribal que permaneceu nas Missões Jesuíticas foi o solidarismo econômico. 0 caráter coletivo da produção indígena foi mantido, onde "O conceito de propriedade privada dos bens não se manifestava [...]. Nela predominava o conceito de comunidade. Somente era propriedade do indígena aqueles elementos de uso pessoal, por exemplo, o arco e as flechas, as redes e as vasilhas de cerâmica" (SNIHUR, 2007, p. 120). Enquanto nas aldeias os habitantes trocavam o que possuíam entre si, nas Missões isso ocorria também no âmbito do sistema: como mencionado, cada missão especializou-se em determinada produção e auxiliava as demais com seus excedentes. Embora os Guarani já praticassem a agricultura anteriormente em pequena escala com algumas espécies destinadas à subsistência, sob a supervisão dos jesuítas passaram a adotar um processo produtivo mais organizado, incluindo a produção de excedentes e de novas culturas trazidas da Europa, e a introdução da pecuária de gado bovino. Neste novo contexto, ocorreu significativa mudança cultural em relação ao trabalho, pois a semeadura também passou a ser realizada pelos homens, que anteriormente se encarregavam da colheita, caça e pesca.

De acordo com Venturini (2009, p. 39), “O desafio maior dos missionários era conseguir a mudança de traços culturais dos índios, incompatíveis com o cristianismo". E um deles estava relacionado à poligamia praticada por direito pelos caciques, que podiam ter as mulheres que pudessem proteger e sustentar. Como parte de sua estratégia para eliminá-la, os padres inseriram junto aos habitantes o uso de vestes e estas passaram a ter significado de identidade, poder e 
status, pois "sobretudo entre os membros do Cabildo [...] as vestes de origem ocidental vieram a desempenhar um papel fundamental na preservação de suas chefias. [...] Só era cacique no espaço missional aquele que se vestisse o mais próximo possível de um europeu" (BAPTISTA, 2009a, p. 147). Além disso, só estabelecia contato com os visitantes da redução o habitante que estivesse devidamente vestido. Contudo, houve grave resistência ao uso de vestes, inclusive por insuficiência do número de peças. E, também houve forte resistência à eliminação da poligamia, pois, ainda que reduzida drasticamente, essa prática permaneceu durante muito tempo (BAPTISTA, 2009a, p. 162).

Grande também era a insatisfação dos jesuítas em relação às festas com consumo de bebidas alcoólicas, em especial cerveja feita de mandioca e milho, a chicha. Enquanto nas aldeias as festas estavam relacionadas a comemorações e vitórias, nas Reduções ocorriam procissões, que eram celebrações realizadas na praça, das quais participavam os indivíduos que aderiram aos hábitos jesuíticos, que desfilavam sobre um tapete de pétalas decorado

por dezenas de arcos adornados por guirlandas de flores, plumas e centenas de alimentos [...]. Ainda atados aos arcos, gritam micos, debatem-se araras e loros e enrolam-se serpentes vivas "amansando sua ferocidade diante de seu criador" [...].

Após procissões, missas e demais atividades ritualísticas, segue-se um conjunto de divertimentos basicamente voltados ao treinamento da destreza dos homens. [...] militares praticam corridas a cavalo ou a pé, [...] encenações de batalhas com resultados previamente combinados [...] "corrida pela argola" [...] disputa por melhores acertos de flechas em alvos [...] jogos de bola de borracha [...] (BAPTISTA, 2009a, p. 184-186).

Já aqueles que não aceitavam usar vestimentas, cometiam algum crime ou não participavam dos trabalhos coletivos (chamados chumas), só assistiam ao ritual. Tais atividades contavam ainda com a presença de moradores de outros povoados e demonstravam a mistura ocorrida entre as 
crenças, pois em um ritual católico coexistiam objetos e atividades indígenas. E, de acordo com Baptista (2009a, p. 37), “As 'borracheiras demoníacas', denominação empregada a rituais indígenas regados a cauim, nesses casos são consideradas pelos padres como manifestação cristã. A tolerância jesuítica impressiona: o problema não está na prática, mas, sim, no destino de sua devoção." Ocorreu a redução de consumo de bebida alcoólica através da introdução do consumo de erva-mate e, por isso, seu cultivo era tão importante e proliferado entre as Missões Jesuíticas.

Portanto, percebe-se que muitos foram os aspectos que influenciaram a formação da cultura missioneira. Mas também muitos foram os impasses que exigiram uma intensa negociação entre as duas culturas sobre diversos aspectos relacionados à vida social e a sua organização para que esse novo modo de vida tivesse chances de funcionar. Embora não tenham ocorrido acordos em todos os âmbitos e aspectos da sociedade, esta é uma construção histórica única, em que as culturas iniciais se mesclaram de tal forma que nenhuma delas permaneceu intacta. Portanto, ao final desta experiência, seus atores alteraram sua percepção de mundo e seu modo de vida de maneira recíproca.

$\mathrm{Na}$ arte missioneira pode-se ver esta interação entre as duas culturas, utilizada pelos padres como forma de disseminação dos valores cristãos e reafirmação dos valores pregados nas liturgias. Desse modo, arte e religião estavam intimamente ligadas. Custódio (2002a, p. 136) afirma que

Sob diferentes denominações, como criollo, mestiço, ou mesmo missioneiro, o Barroco se expressava na profusão das formas curvas e no exagero da dramaticidade. No Novo Mundo, fez escola, e deixou um enorme acervo artístico de pintura e escultura, basicamente utilizando como tema a motivação sacra.

Nas reduções, o espírito Barroco conjugou no espaço físico das igrejas e das praças, as manifestações imateriais das orquestras, dos coros em latim, da 
dança e da encenação, das celebrações sacras, das missas, das procissões, dos enterros e das festas, com ritos e vestimentas especiais [...].

A diversidade de manifestações artísticas existentes nos povos missioneiros se deve principalmente a dois fatos: "o enorme talento do indígena para assimilar e reproduzir formas e conceitos artísticos completamente alheios a sua natureza e realidade" (COUTINHO, 2000, p. 32, tradução nossa ${ }^{36}$ ) e a importância que os jesuítas davam ao ensino artístico. Guiados pelos jesuítas, os indígenas puderam expressar seus dons através das artes, produzindo "numerosas preciosidades em madeira, entre as quais se destacam Nossa Senhora da Conceição e São Lourenço, em cedro policromado. Também produziram numerosas esculturas em arenito e, também, os grandes sinos das igrejas [Figura 12, na próxima página]" (CUSTÓDIO, 2000a, p. 2729, tradução nossa ${ }^{37}$ ). De acordo com o embaixador argentino Mario Ibañez (2000, p. 19, tradução nossa ${ }^{38}$ ), "Essas duas culturas tão diversas alcançaram a síntese de um encontro e uma fusão. Nisso está a conquista fundamental desta singular experiência social". Segundo ele, os estilos artísticos envolvidos, entre eles as imagens românicas e os anjos barrocos, são apenas fragmentos de uma realidade modificados diante da interação entre as duas culturas. Os jesuítas ensinaram as técnicas, orientaram sobre quais imagens produzir e sua significância, e os indígenas produziram uma iconografia missioneira característica. Nas palavras de Snihur (2007, p. 151) “A

\footnotetext{
${ }^{36}$ Do original em espanhol: "[...] el enorme talento del indígena para similar y reproducir formas y conceptos artísticos completamente ajenos a su naturaleza y realidad" (COUTINHO, 2000, p. 32).

${ }^{37}$ Do original em espanhol: "[...] numerosas preciosidades en maderas, entre las que se destacan Nuestra Señora de la Concepción o San Lorenzo, en cedro policromado. También producirán numerosas esculturas en piedra de arena y, asimismo, as grandes campanas de las iglesias" (CUSTÓDIO, 2000, p. 27-29).
}

${ }^{38}$ Do original em espanhol: "Esas dos culturas tan diversas alcanzaron la síntesis de un encuentro y una fusión. En ello consiste el fundamental logro de esta singular experiencia social” (IBAÑEZ, 2000, p. 19). 

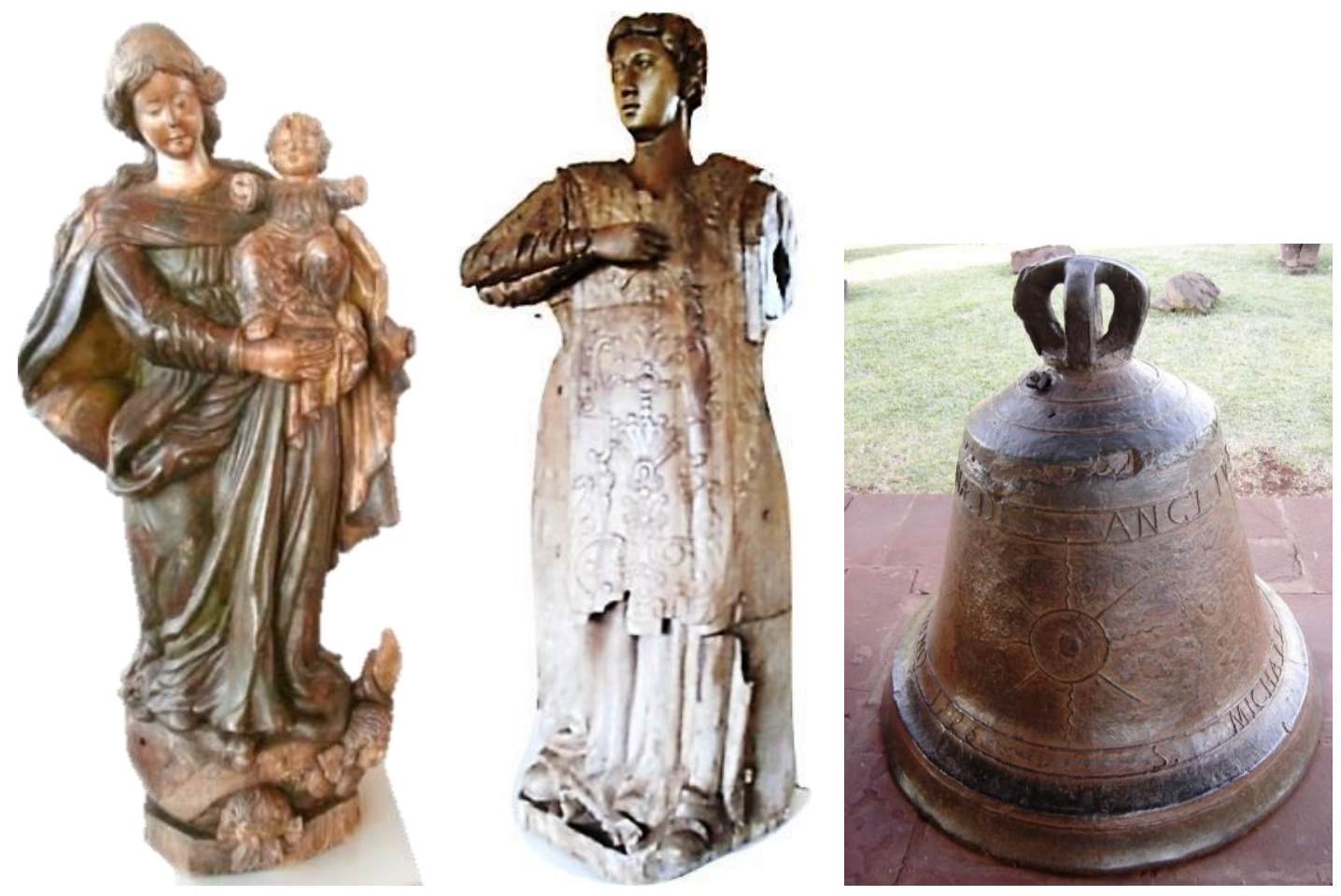

Figura 12. Nossa Senhora da Conceição, São Lourenço e Sino de São Miguel. Fonte: Fotos da autora. 
tarefa da Companhia de Jesus teve o grande mérito de conseguir respeitar a cultura guarani e recriá-la sob a luz do Evangelho para atingir seu objetivo: a cristianização dos aborígenes". Segundo o procurador argentino Aníbal Ibarra (2000, p. 11), além de imagens para os cultos, que tinham um apreço impressionante dos indígenas, produziam também móveis, utensílios de ferro, relojoarias, pratarias e instrumentos musicais, sempre sob a orientação dos padres, que possuíam os conhecimentos necessários para a confecção de tais itens. Segundo Snihur (2007, p. 161), “Os mais comuns e presentes em todas as Reduções eram flautas, fagotes, clarinetes, liras, violinos, violões, trompetes e clarins", e "Em meados do século XVII, todos os povoados já possuíam seus corais e bandas de músicos. As peças eram cantadas em latim, espanhol ou guarani" (SNIHUR, 2007, p. 161). Eram cópias de instrumentos europeus, com os quais produziam músicas de estilo europeu, tendo sido qualificadas como as melhores da religião do Rio da Prata em sua época, devido à afinidade que os guarani demonstravam com a música. E por muito tempo, ao menos até a primeira metade do século XIX de acordo com Baptista e Santos (2009, p. 147), "as habilidades musicais dos indígenas permanecem destacáveis", e muitos índios utilizavam tal habilidade como instrumento de integração.

Portanto, apesar de constituírem também uma forma de evitar o ócio (VENTURINI, 2009, p. 38), os afazeres realizados sob a orientação dos jesuítas permitiram ao "indígena descobriu que os métodos e técnicas de expressão [...] vinham propostos de fora do seu contexto cultural, mas que Ihes serviam como ferramentas de expressão para manifestar suas próprias concepções estéticas" (SNIHUR, 2007, p. 155). De tal forma que este processo de interação entre as duas culturas produziu uma arte única e exuberante, como se pode perceber nas obras remanescentes encontradas nos museus e nos sítios históricos (Figuras 13, 14 e 15, na próxima página). 


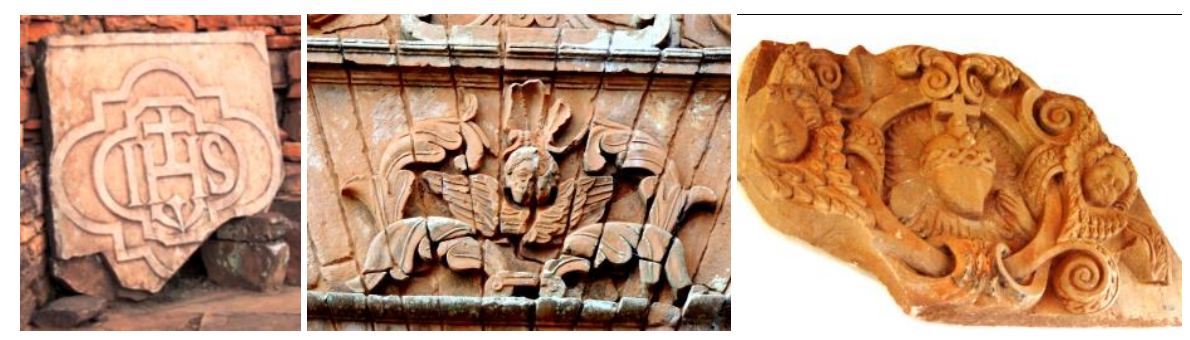

Figura 13. 1. Símbolo da Companhia de Jesus em San Ignácio Miní. 2. Trinidad. 3. Sagrado coração em São Miguel. Fonte: Fotos da autora.
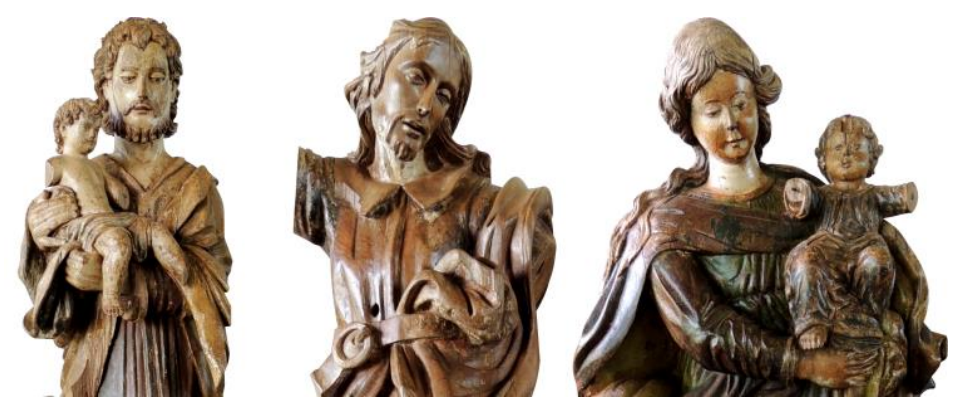

Figura 14. Santos no Museu das Missões, em São Miguel: 1. São José. 2. Santo Isidro. 3. Nossa Senhora da Conceição. Fonte: Fotos da autora.

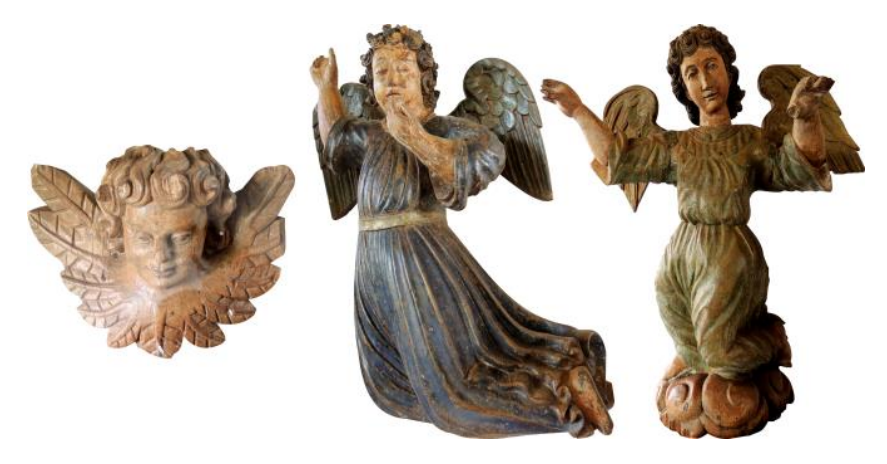

Figura 15. Anjos no Museu das Missões, em São Miguel. Fonte: Fotos da autora. 
De acordo com Venturini, até hoje as Missões Jesuíticas "despertam a atenção dos estudiosos devido à sociedade solidária e de excepcional desenvolvimento que criaram" (VENTURINI, 2009, p. 25). Segundo Snihur, elas constituíram "um projeto de integração social, político e econômico de uma valiosa originalidade", em que "a comunidade guarani e os Padres da Companhia de Jesus se integraram em um complexo mecanismo que envolvia as diferentes crenças e visões do mundo" (SNIHUR, 2007, orelha). E sua importância é reconhecida mundialmente, como se pode perceber nas palavras de Gutiérrez (2004, p. 17):

As Missões que os Jesuítas formaram entre os índios Guarani do Paraguai constituíram uma experiência cultural e social de notável magnitude. Em um período breve, compreendido entre 1610 e 1767, milhares de indígenas formaram dezenas de povoados, organizaram uma economia comunitária e complementar, alcançando elevados níveis de vida, desenvolvimento artístico e cultural. Esta experiência, que transcende os testemunhos materiais que ainda subsistem, configura-se em uma das iniciativas mais claras de desenvolvimento de uma sociedade solidária em uma visão teocêntrica, como a que implantaram os religiosos.

Já Ribeiro (1995, p. 54), afirma que

O projeto jesuítico [brasileiro] era tão claramente oposto ao colonial que resulta espantoso haver sido tentado simultaneamente e nas mesmas áreas e sob a dominação do mesmo reino. Os conflitos resultantes das disputas pelo domínio dos índios não permitiram que as missões jesuíticas alcançassem, em terras brasileiras, a dimensão, quanto ao número de indígenas reunidos, nem o nível de organização e prosperidade que a Companhia de Jesus conquistou no Paraguai. 
Pegando emprestados os conceitos do biólogo norte-americano James Grier Miller (1978), entende-se que, além deste caráter de rede do suprasistema missioneiro, havia uma ligação e interação entre todos os elementos, materiais e humanos, e subsistemas sociais, que contribuíram para sua criação. Nas palavras de Baptista e Santos (2009, p. 7):

No que se chama [atualmente] de ruínas, longe está de haver uma morte das
populações que habitavam os espaços missionais. Sequer estão, tanto para as
populações nativas quanto para os novos personagens que ali chegam,
desprovidas de significados e utilidades. Ocorria - como ainda ocorre -, tanto
na esfera física quanto mental, uma viva interligação entre homens e
estruturas, uma verdadeira sinergia onde ambas as partes só existem por se
contatarem, como que uma assegurando a existência da outra.

Baseando-se no pensamento complexo, entende-se que a experiência ocorrida nas Missões Jesuíticas tomou forma pela interação de diversos atores em um processo de conversação entre suas culturas originais, que resultou na criação de um modo de ver o mundo distinto dos dois que o originaram. Pode-se afirmar que a concepção filosófica da Companhia de Jesus só obteve sucesso devido ao seu caráter adaptativo. Ou seja, a capacidade dos jesuítas de absorverem parte da cultura indígena foi crucial para que esta experiência fosse tão bem sucedida.

Sem dúvida, na arte se encontram os produtos mais marcantes desta experiência. Segundo Juan Luís Suárez (2007), sua singularidade representa sua própria complexidade e demonstra o mecanismo de adaptação que constituiu esta cultura: mistura entre uma base espanhola e a habilidade, a criatividade e a interpretação do guarani. Uma arte que, segundo Lucio Costa (2010 [1941]) era considerada ultrapassada na Europa saturada de renascimento, mas na região onde aflorou representa o que se tem de mais antigo e, por isso, é seu patrimônio e deve ser preservado. 
Como afirma o antropólogo argentino Guillermo Wilde (2010), uma perspectiva complexa concebe cada um dos aldeamentos como espaços religiosos, culturais e políticos, onde ocorreram interações adaptativas individuais e coletivas entre as culturas nativa e espanhola, envolvendo diversos elementos e agentes. Este processo recíproco de interação foi marcado profundamente por relações entre e no interior dos sistemas culturais envolvidos, causadas pelo confronto de suas diferenças. As soluções promovidas pela negociação, concessão e criatividade, culminaram em uma terceira cultura: híbrida, miscigenada, que se caracteriza como um sistema dinâmico, em constante transformação. O primeiro sistema cultural complexo e transcontinental da modernidade, como afirma Suárez (2007); em um território encravado em uma região cuja característica de organização social era tão antagônica à sua. Estes trinta aldeamentos possuíam uma independência geográfica do território onde se encontravam ${ }^{39}$ e, ao mesmo tempo, uma interdependência entre eles, caracterizada pelo auxílio mútuo e possibilitada pelo que Ibañez (2000) chama de "prodigiosa e eficaz utilização de comunicações e de informação". De modo que o autor acredita que este sistema antecipou "um mundo global que permitia e respeitava o desenvolvimento dos canais humanos da criação" (IBAÑEZ, 2000, p. 19, tradução nossa ${ }^{40}$ ).

Portanto, o desenrolar do pensamento científico nos auxilia a compreender melhor o funcionamento e a importância de uma experiência como esta, contribuindo com conceitos essenciais para sua análise. Neste contexto, o pensamento complexo é capaz de embasar um processo de reflexão mais adequado à questão em pauta nesta pesquisa e foi escolhido para embasar esta análise porque se dispõe a lançar um olhar diferenciado sobre os sistemas, com o

\footnotetext{
${ }^{39}$ Os trinta povos não possuíam independência administrativa (Custódio, 2014).

${ }^{40}$ Do original em espanhol: "[...] una prodigiosa y eficaz utilización de comunicaciones y de información. Anticiparon un mundo global que permitía y respetaba el desarrollo de los cauces humanos de la creación” (IBAÑEZ, 2000, p. 19).
} 
objetivo de pensar a interação entre seus elementos constituintes e o ambiente, produzindo uma reforma necessária no pensamento acadêmico e científico. Contudo, para Morin a complexidade não é uma receita, nem um substituto para a simplificação, cujo mal-entendido principal está

[...] em confundir a complexidade com a completude.

Acontece que o problema da complexidade não é o da completude, mas o da incompletude do conhecimento. [...] a ambição da complexidade é prestar contas das articulações despedaçadas pelos cortes entre disciplinas, entre categorias cognitivas e entre tipos de conhecimento. De fato, a aspiração à complexidade tende para o conhecimento multidimensional. Ela não quer dar todas as informações sobre um fenômeno estudado, mas respeitar suas diversas dimensões (MORIN, 2005 [1970], p. 176).

A Complexidade concebe o estado de equilíbrio num sistema social como uma estagnação, ou o mesmo que a morte em um organismo vivo. De tal forma que esse estado é muito improvável, pois, de acordo com o ciberneticista Paul Pangaro (2007, p. 117), o sistema está em constante "interação com o ambiente, e [...] via ambiente". E a interação

[...] difere de "resposta" ou simplesmente "ação", uma vez que o comportamento é definido enquanto relação com o ambiente (a resposta é apenas um dos elementos da interação).

Podemos definir interação interpessoal ou interação social como uma relação de interdependência entre duas ou mais pessoas, onde a ação de cada uma depende da ação do outro. Numa interação interpessoal (que caracteriza a comunicação humana), temos três fatores: os participantes, a relação em si e o contexto (LOBATO, 2009, p. 2).

Através da interação entre os elementos do sistema que as Missões Jesuíticas constituem, foram negociadas diversas instâncias do cotidiano, guiando um processo de gênese de uma nova cultura e, por consequência, destruição daquelas que a originaram. Claro que essa não era a intenção inicial, mas emergiu das necessidades encontradas durante o processo. 0 sistema emergente é considerado aqui como adaptativo porque utiliza a auto-observação das interações 
ocorridas em seu interior como forma de gerar um feedback para uma autorregulação. Processo que faz emergir novas formas dentro de si mesmo, que são, por sua vez, auto-observadas num ciclo que se retroalimenta. Participam deste processo de controle (no sentido cibernético do sistema que possui um guia) os padres e aqueles habitantes que fazem parte do cabildo, em especial os caciques, que representam administrativamente seus povos junto aos missionários.

\footnotetext{
Nesse processo, novos valores, novas características e até novas identidades vão sendo criados, assumidos ou incorporados. Os liderados, por sua vez, passam também a ter uma outra imagem de seu líder, imagem essa que vai se construindo a partir das novas funções ocupadas por eles como intermediários entre o mundo indígena e o mundo ocidental (ALMEIDA apud BAPTISTA, 2009a, p. 151).
}

Portanto, as Missões Jesuíticas podem ser consideradas complexas em dois âmbitos: um macro, referente ao conjunto formado pelas trinta Reduções e a filosofia que constitui sua origem; e um micro, relativo aos subsistemas que compõem a sociedade missioneira. Segundo Morin (2005 [1970]), a complexidade se revela dentro do sistema quando se percebe que ele constitui menos e mais do que a soma de suas partes. Isso porque as interações que ocorrem entre seus elementos podem inibir o aparecimento de características (menos) ou estimulá-las (mais). Tais propriedades são emergentes e, portanto, são constatadas empiricamente, mas não podem ser deduzidas pela lógica. $\mathrm{O}$ autor afirma que desse modo percebe-se que "a existência de uma cultura, de uma linguagem, de uma educação, propriedades que só podem existir no nível do todo social, recaem sobre as partes para permitir o desenvolvimento da mente e da inteligência dos indivíduos" (MORIN, 2005 [1970], P. 190).

Em relação à sociedade, Morin (2005 [1970]) ainda acrescenta que ela constitui uma organização acêntrica, pois funciona através de interações espontâneas; policêntrica, pois é 
coordenada por diversas organizações existentes em seu interior, e cêntrica, pois sempre possui um centro de decisão. Diante das regras produzidas por tais organizações, o indivíduo é formado pela sociedade, ou seja, ela é parte integrante dele em sua visão de mundo. Em 1970, enquanto o filósofo francês Louis Althusser acreditava que a influência da sociedade sobre o indivíduo seria negativa por representar a dominação do indivíduo (como uma venda sobre seu sentido de olhar o mundo com suas próprias ideias e conclusões), Morin a apresentava como uma maneira de integrar o singular ao todo, uma forma imprescindível de o indivíduo fazer parte daquela sociedade e de sua cultura. Pode-se dizer também que é o modo como ele sobrevive no ecossistema onde se insere. Ou seja,

[...] Uma sociedade é produzida pelas interações entre indivíduos e essas interações produzem um todo organizador que retroage sobre os indivíduos para co-produzí-los enquanto indivíduos humanos, o que eles não seriam se não dispusessem da instrução, da linguagem e da cultura. Portanto, o processo social é um círculo produtivo ininterrupto no qual, de algum modo, os produtos são necessários à produção daquilo que os produz. [...] [conforme a] noção de círculo retroativo de Norbert Wiener (no qual o efeito retorna de modo causal sobre a causa que o produz) (MORIN, 2005 [1970], p. 182).

O indivíduo atua segundo ele mesmo e as influências que recebe e processa como mediador de múltiplas interações com outros atores. Quando ele fala, é ele mesmo falando com sua interpretação influenciada pelo sistema onde se insere, mas de modo algum é uma opinião da sociedade como um todo, pois, como afirma Morin, existem ordem e desordem na desordem, ou seja, dentro da sociedade existem grupos de elementos insatisfeitos com as mesmas coisas e também com coisas diferentes. O que também se reflete na organização do espaço físico das Reduções e na ordem social. De acordo com Baptista (2009a, p. 189-190),

são bastante próximos os conteúdos encontrados na área jesuítica dos povoados (oficina, claustro/escola, igreja, cemitério e cotiguaçu) e aqueles encontrados nas áreas dos chamados cacicados, denominação da época 
referente às famílias extensas. Basta verificar seus frequentadores e as funções exercidas em cada um dos espaços da área, onde homens, mulheres e crianças articulam-se no exercício da criação e manutenção daquela sociedade. Ali, os próprios jesuítas se inserem na qualidade de líderes com amplas funções, tais como organização e orientação das atividades masculinas, atendimento das crianças e mulheres, além de cuidados aos mortos, deuses e espíritos.

Contudo, os indígenas nunca se tornaram cegos seguidores das regras designadas pelos jesuítas. O que gerou um intenso processo de negociação em relação aos mais diversos aspectos da sociedade missional.

Diante do exposto, constata-se que as Missões Jesuíticas constituíram um sistema complexo em seu passado. Como afirmam Norma Barbacci e Fábio Grementieri (2004b, p. 20),

trata-se de um patrimônio comum que demonstra, como nenhum outro, uma vocação regional originária, uma herança histórica compartilhada e uma projeção de identidade política, social, econômica e cultural integradora [...].

E como complementa Mujica (2004a, p. 21),

O valor do patrimônio Jesuítico-Guarani está na combinação das características materiais dos bens, na geografia cultural gerada, no que representa em um período específico e transcendente da história, e em que vários países compartilham um processo histórico particular e as manifestações materiais que ficaram como seu testemunho. Em resumo, o valor do patrimônio JesuíticoGuarani é a soma das partes.

Dessa forma acredita-se que existe a necessidade de trabalhar o registro, a preservação, a divulgação e a apropriação do patrimônio missioneiro como um todo complexo, através de suas manifestações materiais e imateriais, permitindo uma visão global, o diálogo e a complementação do conhecimento de estudiosos entre si e com a comunidade. Pois não foi o jesuíta que construiu 
a experiência das Missões, nem a Companhia de Jesus, nem os indígenas, mas sim a interação única entre todos os elementos e agentes internos e externos a este sistema específico.

Segundo o pensamento de Suárez (2007), esta realidade complexa da cultura missioneira é marcada não somente pelos habitantes da América e pelos jesuítas, mas também por agentes externos, transatlânticos, cujas decisões influenciaram a história. Agentes externos atuantes sobre este sistema aberto, a Coroa Espanhola e a Companhia de Jesus foram elementos controladores por seu poder decisório, neste território onde possuíram uma extensão de sua estrutura política, econômica e religiosa. Mas também possibilitaram este processo de interação por sua localização além-mar: a distância fez com que sua atuação plena fosse dificultada. Devido à demora dos meios de comunicação da época, muitas decisões precisaram ser tomadas pelos padres mediante o diálogo com a cultura local. Desse modo, a dualidade geográfica AméricaEuropa característica desta experiência histórica também propõe uma ampliação do olhar lançado sobre as Missões Jesuíticas: trabalhos futuros podem envolver não somente o conjunto missioneiro regional, mas toda a expressão cultural da Companhia de Jesus nos dois continentes.

Neste contexto, a próxima discussão recai sobre uma visão da preservação como um sistema complexo e, para isso, analisam-se os vestígios de três Reduções: São Miguel Arcanjo - Brasil, San Ignácio Miní - Argentina e Santíssima Trinidad - Paraguai. Tais sítios históricos foram escolhidos pelo seu estado de conservação e por reunirem grande quantidade de material para estudo, representando parte do patrimônio de cada um dos três países em cujos territórios estão localizadas atualmente as missões. Esta escolha por um exemplar em cada país pode parecer contraditória à abordagem adotada das Missões Jesuíticas como um conjunto, contudo ela objetiva possibilitar a análise de como cada país trabalha o registro, a preservação e a divulgação das Reduções em seu território, uma vez que tais trabalhos são realizados nacionalmente. 
“[...] Também o patrimônio não deve ser visto a partir do passado, mas a partir do presente, como categoria de ação do presente e sobre o presente [...]"

(HARTOG, 2006, p. 270) 
A partir de informações obtidas nas visitas técnicas realizadas em Janeiro de 2013 aos três sítios históricos selecionados, São Miguel - Brasil, Trinidad - Paraguai e San Ignácio Miní - Argentina, este segundo capítulo analisa as ações realizadas após um extenso período de hibernação, entre a expulsão dos jesuítas em 1750, quando foram abandonadas, e a redescoberta das ruínas dois séculos depois. Pretende-se entender como ocorrem as interações entre os elementos físicos, imateriais e humanos no interior do que este trabalho denomina sistema de preservação do patrimônio missioneiro, com especial atenção às atividades de pesquisa, preservação e divulgação segundo as políticas preservacionistas nacionais em vigência nos respectivos países.

Neste sistema, a preservação e a percepção das Missões estão atreladas a diversos elementos, que podem ser divididos em duas categorias: 1. Patrimônio e 2. Agentes e suas interações. A primeira categoria, tratada no segundo item deste capítulo, diz respeito ao “conjunto patrimonial das Missões Jesuíticas dos Guarani [que] é constituído por uma série de bens culturais imóveis, móveis, materiais e imateriais de grande significado histórico e cultural para cidades, estados e países onde se localizem" (BARBACCI; GREMENTIERI, 2004b, p. 19). O patrimônio material é constituído por todo o acervo físico, que inclui as ruínas das edificações e outros elementos distribuídos pelos sítios históricos (patrimônio imóvel) e obras de arte conservadas no interior de espaços museológicos, principalmente estatuária e instrumentos musicais (patrimônio móvel). Por um lado, o patrimônio imaterial se refere a toda a cultura e a história que permeiam tais objetos e são fruto das relações desenvolvidas durante a atuação da Companhia de Jesus neste território do chamado Novo Mundo. Enquanto isso, a segunda categoria, denominada agentes e suas interações, é tratada no terceiro item deste capítulo e envolve órgãos responsáveis, pesquisadores, comunidade e guias de turismo; e as ações já realizadas em relação ao patrimônio missioneiro e aquelas que podem ser vislumbradas a partir de um olhar embasado no pensamento sistêmico.

Esta análise tem a finalidade de enfatizar a necessidade de uma preservação integrada de todos os tipos de bens patrimoniais e que envolva ações relacionadas a todos os agentes envolvidos para o pleno funcionamento deste sistema, de modo a justificar a permanência deste patrimônio através do maior estímulo à apropriação pela comunidade local e internacional.

Imagem da página anterior: São Miguel- Brasil (CHAROLA; MAGADÁN, 2009, p. 167). 
A necessidade de considerar a preservação das Missões Jesuíticas como um sistema se deve inclusive à complexidade imposta pelo caráter fragmentado deste patrimônio histórico, que vê seus remanescentes reduzidos em quantidade e qualidade pela ação do tempo e dos homens. Após a criação dos atuais estados nacionais, as antigas Reduções estão divididas conforme a Figura 16, na próxima página. De acordo com o historiador esloveno Bozidar Sustersic (1999, p. 157), enquanto as quinze vilas argentinas ${ }^{41}$ foram demolidas e as sete brasileiras ficaram desertas, as oito Missões paraguaias receberam a população das Reduções brasileiras. Segundo o arquiteto argentino José Pozzobon (2004, p. 5, tradução nossa ${ }^{42}$ ),

[...] A unidade monolítica territorial, cultural e étnica, que foi característica das Missões, entrou em crise com o advento da expulsão da Companhia de Jesus e depois com os movimentos revolucionários nacionais, nos primeiros anos do século XIX [...].

Desintegração territorial, despovoamento, desorganização política, institucional e administrativa, foram os fatores decisivos que arrastaram os povos ao estado de ruína arquitetônica e urbana. [...].

Snihur (2007) salienta que o estado atual dos sítios históricos foi influenciado de maneira

${ }^{41}$ Para facilitar sua identificação, as missões são aqui caracterizadas por sua localização atual dentre os territórios nacionais formados posteriormente ao Tratado mencionado.

${ }^{42}$ Do original em espanhol: "[...] La monolítica unidad territorial, cultural y étnica, que fue característica de Misiones, hizo crisis con el advenimiento de la expulsión de la Compañía de Jesús y luego con los movimientos revolucionarios nacionales, en los primeros años del siglo XIX. [...]

Desintegración territorial, despoblación, desorganización política, institucional y administrativa, fueron los factores decisivos que arrastraron a los pueblos al estado de ruina arquitectónica y urbana. [...]" (POZZOBON, 2004, p. 5). 


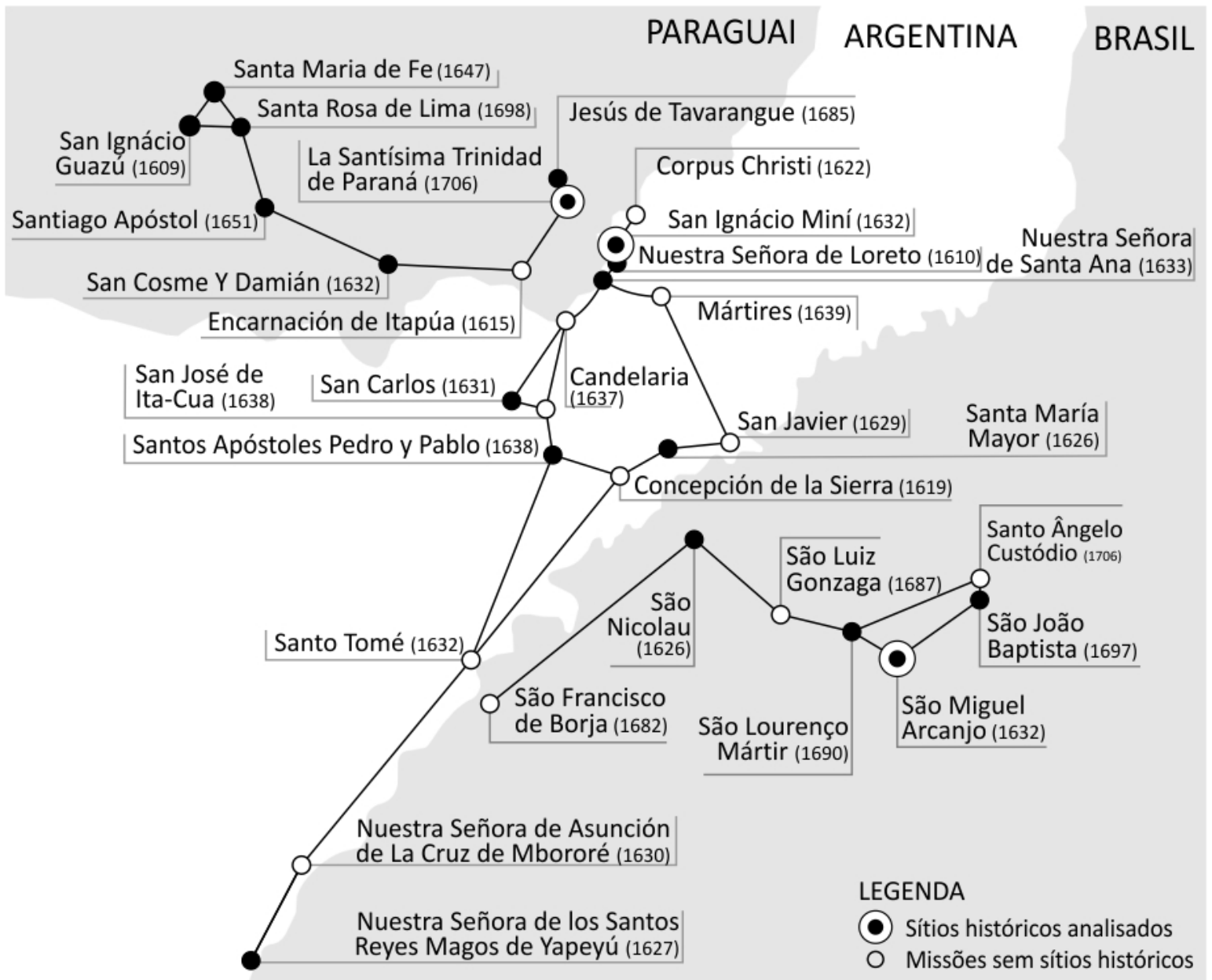

Figura 16. As Trinta Reduções Jesuíticas nos países em que se localizam atualmente. Fonte: Elaborada pela autora. 
incisiva também pelo despovoamento, pois a consequente redução do setor de moradias das Reduções provocou a deterioração dos edifícios, inclusive por descuido e por falta de conhecimento sobre manutenção por parte dos habitantes. Segundo o autor, apesar de várias autoridades demonstrarem preocupação com o estado dos sítios históricos, "As últimas décadas do século XVIII transcorreram sem soluções concretas para os prédios dos povoados missioneiros, e o seu estado ruinoso se acrescentou" (SNIHUR, 2007, p. 182). Além disso, alguns sítios históricos simplesmente deixaram de existir pela pilhagem de materiais de construção, pela construção de cidades ou estradas sobre suas ruínas. Segundo Custódio (2014), em São Miguel - Brasil, essa destruição foi promovida pelo próprio governo municipal (na época da cidade de Santo Ângelo), que vendeu o material para os colonos para a construção de suas casas. $O$ autor afirma ainda que esta missão se transformou em uma verdadeira pedreira, de onde o material era vendido ou roubado. Segundo ele, as pedras tinham seu preço estipulado de acordo com o nível de detalhamento, sendo mais caras aquelas com melhor acabamento ou ornamentos.

Restam apenas dezoito Reduções com sítios históricos:

[...] sete na Argentina (San Ignácio Miní, Santa Ana, Loreto, Santa María la Mayor, Yapeyú, San Carlos, Apóstoles); quatro no Brasil (São Nicolau, São Miguel, São Lorenzo, São João) e sete no Paraguai (Trinidad, Jesús, San Ignácio, Santa María de Fe, San Cosme y Daminán, San Santiago e Santa Rosa) (STEFANO, 1997, p. 188, tradução nossa ${ }^{43}$ ).

\footnotetext{
${ }^{43}$ Do original em inglês: "[...] seven in Argentina (San Ignácio Miní, Santa Ana, Loreto, Santa María la Mayor, Yapeyú, San Carlos, Apóstoles); four in Brazil (São Nicolás, São Miguel, São Lorenza, São João) and seven in Paraguay (Trinidad, Jesús, San Ignácio, Santa María de Fe, San Cosme y Daminán, San Santiago and Santa Rosa)" (STEFANO, 1997, p. 188).
} 

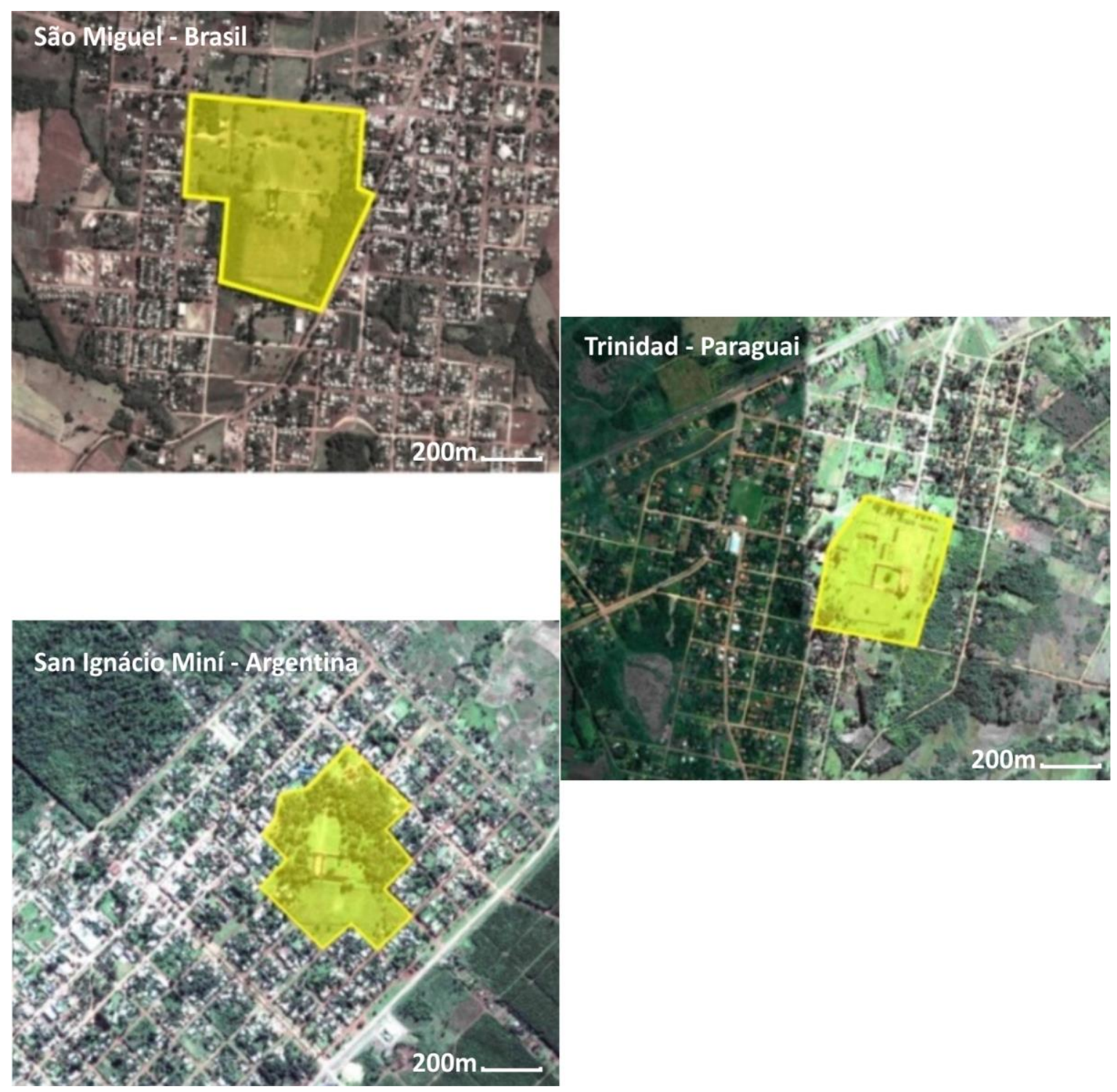

Figura 17. Localização dos sítios históricos em relação às cidades:

São Miguel Arcanjo - Brasil, Trinidad - Paraguai, e San Ignácio Miní - Argentina.

Fonte: Elaborada pela autora sobre imagens do Google Earth. 
Contudo, mesmo as Missões Jesuíticas que já não possuem sítios históricos contribuem para o entendimento da experiência missioneira através de sítios arqueológicos e de patrimônio material móvel (principalmente estatuária) e imaterial (documentos históricos e relatos). Por exemplo, o relato de formação de São João Batista (realizado pelo Pe. Antonio Sepp no livro "Viagem às Missões Jesuíticas e trabalhos apostólicos") é um dos registros mais importantes sobre o cotidiano missioneiro.

\section{Patrimônio material imóvel}

Atualmente, os três sítios históricos analisados nesta pesquisa encontram-se em meio às malhas urbanas das cidades construídas ao seu redor (Figura 17, na página ao lado), em parte por dois fatores proporcionados pela pré-existência dos aldeamentos jesuítico-guarani: 1. A proximidade de fonte de água e localização privilegiada em áreas mais altas (características necessárias aos locais de implantação das Reduções); e 2. O fácil reestabelecimento da infraestrutura de rede de caminhos que interligava os Trinta Povos, que foi fundamental para o acesso e o desenvolvimento contemporâneo destas regiões. Os remanescentes de várias Reduções não analisadas nesta pesquisa encontram-se em meio às matas (Figura 18, na próxima página).

A relação entre o traçado das Reduções e as cidades em seguida implantadas ao seu redor pode ser analisada através de reconstruções hipotéticas apresentadas por Maeder e Gutiérrez (2010) de São Miguel Arcanjo - Brasil e de San Ingacio Miní - Argentina, ao serem sobrepostas a 

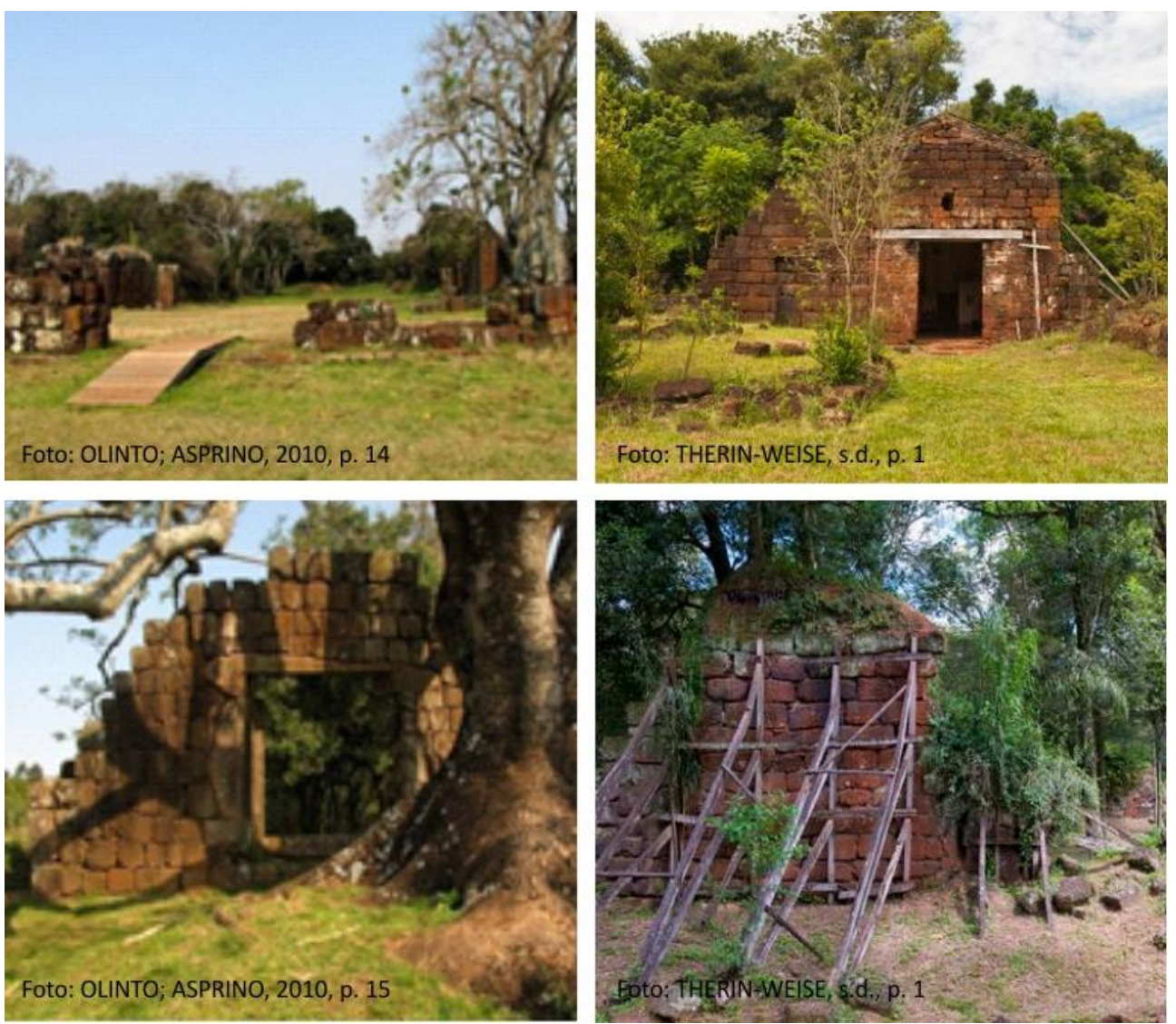

Figura 18. Ruínas em meio às matas. De cima para baixo: 1. São João Batista e 2. São Lourenço Mártir, no Brasil; e 3. e 4. Santa María Mayor, na Argentina. Fonte: Créditos nas fotos. 
imagens atuais dos sítios históricos (Figura 19, na próxima página). A reconstrução de São Miguel Brasil foi realizada em 1947 por Lucas Mayerhofer e atualmente, após novas descobertas arqueológicas, sabe-se que alguns de seus aspectos não estão corretos (como o alinhamento de algumas moradias). Contudo, apesar de sua desatualização, através dela é ainda possível entender parcialmente a organização espacial desta missão.

Para a implantação da cidade atual de São Miguel foram aproveitados alguns eixos viários principais da antiga missão no sentido leste-oeste. Enquanto isso, San Ignácio Miní revela o que Maeder e Gutiérrez (2010, p. 90) chamam de uma "[...] total autonomia do traçado do povo em relação à antiga missão jesuítica. [...] o traçado urbano praticamente 'cerca' o sítio das ruínas e sabemos que elas, até meio século atrás, estavam ocultas em um espesso monte" coberto de árvores (Custódio, 2014). Percebe-se nesta mesma figura que a área de preservação em São Miguel - Brasil envolve não somente a região em que se encontram ruínas visíveis, mas todo o território em que havia edificações missioneiras, protegendo áreas de interesse arqueológico, em que podem ser encontrados vestígios desta missão. Já o sítio argentino não engloba parte do território em que estavam assentadas algumas casas, provavelmente pela ocupação destes espaços com novas construções no momento em que ocorreram as ações de preservação. E, segundo Pozzobon (2004, p. 15, tradução nossa ${ }^{44}$ ),

Fora do setor cercado pelas Ruínas persistem ainda inumeráveis vestígios, pertencentes em sua maioria às Moradias periféricas e a instalações de âmbito

\footnotetext{
${ }^{44}$ Do original em espanhol: "Fuera del sector cercado por las Ruinas persisten aún innumerables vestigios, pertenecientes en su mayoría a las Viviendas periféricas y a instalaciones del ámbito productivo. Estos restos, sin tener un carácter monumental, poseen sin embargo un inestimable valor arqueológico e histórico" (POZZOBON, 2004, p. 15).
} 

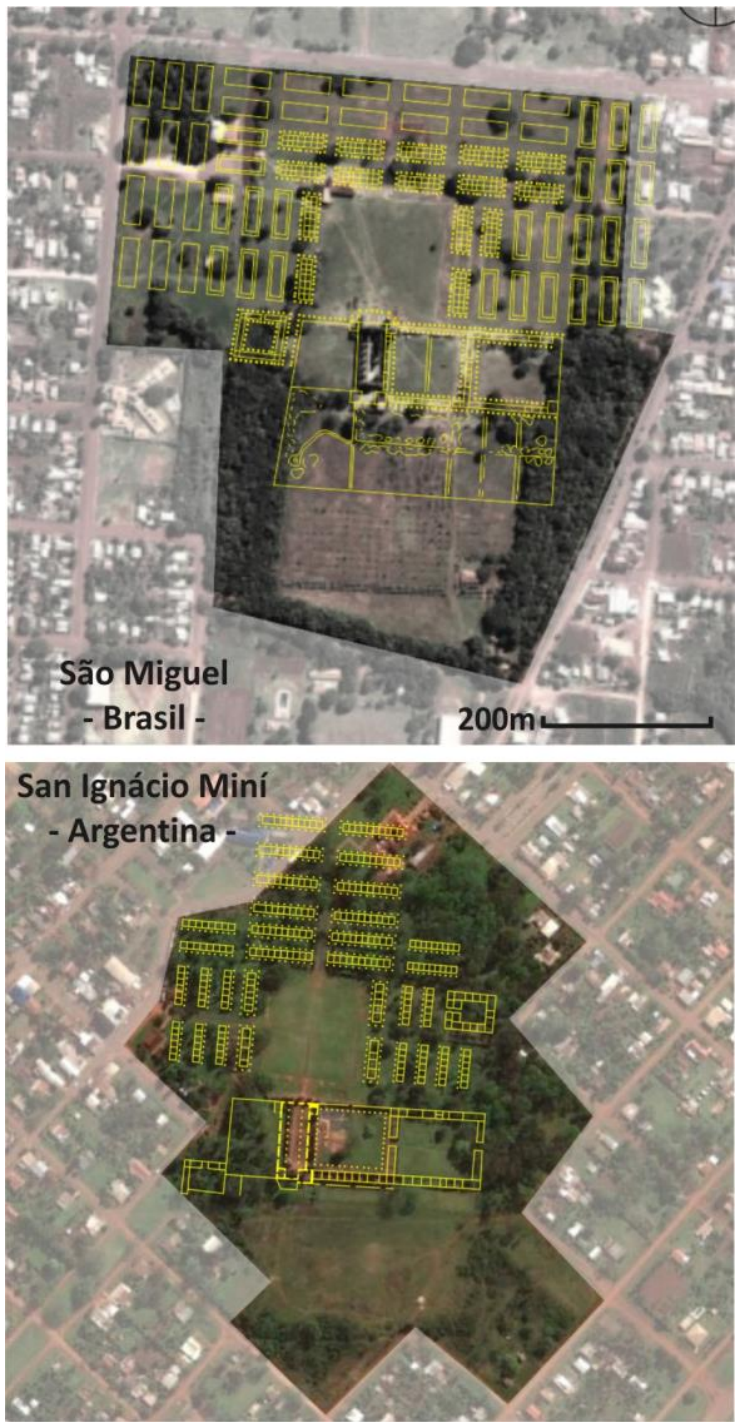

Figura 19. Sobreposições das reconstruções hipotéticas das Reduções de São Miguel Arcanjo - Brasil (realizada em 1947 por Lucas Mayerhofer, mas atualmente sabe-se que alguns aspectos desta reconstrução não estão corretos)

e de San Ignácio Miní - Argentina sobre as cidades atuais.

Fonte: Elaborada pela autora sobre imagens do Google Earth,

com base em reconstruções encontradas em MAEDER; GUTIÉRREZ, 2010, p. 53 e p. 91. 
produtivo. Estes remanescentes, sem ter um caráter monumental, possuem, porém um valor arqueológico e histórico inestimável.

O estado de conservação das edificações dos sítios históricos é precário pela destruição provocada num momento imediato às guerras, pela pilhagem de materiais de construção, e também por "[...] uma série de [outros] fatores que favorecem a deterioração das estruturas, alguns relacionados a questões de origem e outros ao desenvolvimento histórico dos sítios [...]" (CHAROLA; MAGADÁN; LANCELLOTTI, 2004, s.p., tradução nossa ${ }^{45}$ ); dentre eles, abandono e saques, a vegetação, a deterioração dos elementos estruturais, intervenções inadequadas, esforços mecânicos e a poluição do ar. Nos sítios históricos missioneiros desta região, não há nenhuma edificação que conserve a cobertura original. Além disso, muros e paredes remanescentes, na maioria das vezes, não estão completos.

Nenhum dos templos imponentes [das Trinta Missões Jesuíticas] persiste. Alguns deles caíram, como o de Trinidad, outros foram demolidos, como o de Itapuá, e a maioria deles foi destruída pelo fogo. [...] (SUSTERSIC, 1999, p. 157, tradução nossa ${ }^{46}$ ).

De tal forma que cada um dos sítios históricos analisados nesta pesquisa é "caracterizado por uma implantação específica e um estado de conservação diferente" (UNESCO, 2013b, p. 2, tradução nossa ${ }^{47}$ ), como pode ser visto nas Figuras 20, 21 e 22, nas próximas páginas.

\footnotetext{
${ }^{45}$ Do original em espanhol: "[...] una serie de factores que favorecen el deterioro de las estructuras, algunos relacionados a cuestiones de origen y otros al desarrollo histórico de los sitios. [...]" (CHAROLA; MAGADÁN; LANCELLOTTI, 2003, s.p.).

${ }^{46}$ Do original em inglês: "None of the imposing temples remains. Some of them fell down, like that of Trinidad, others were demolished, like that of Itapuá, and most of them were destroyed by fires. [...]" (SUSTERSIC, 1999, p. 157).

${ }^{47}$ Do original em inglês: "[...] each of the reducciones is characterized by a specific layout and a different state of conservation [...]" (UNESCO, 2013b, p. 2).
} 


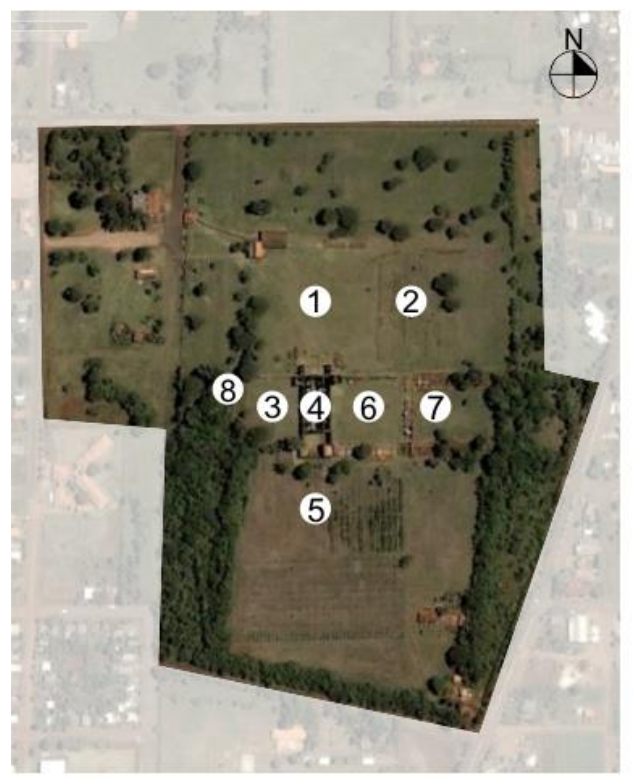

\section{SÃO MIGUEL \\ ARCANJO \\ - BRASIL -}
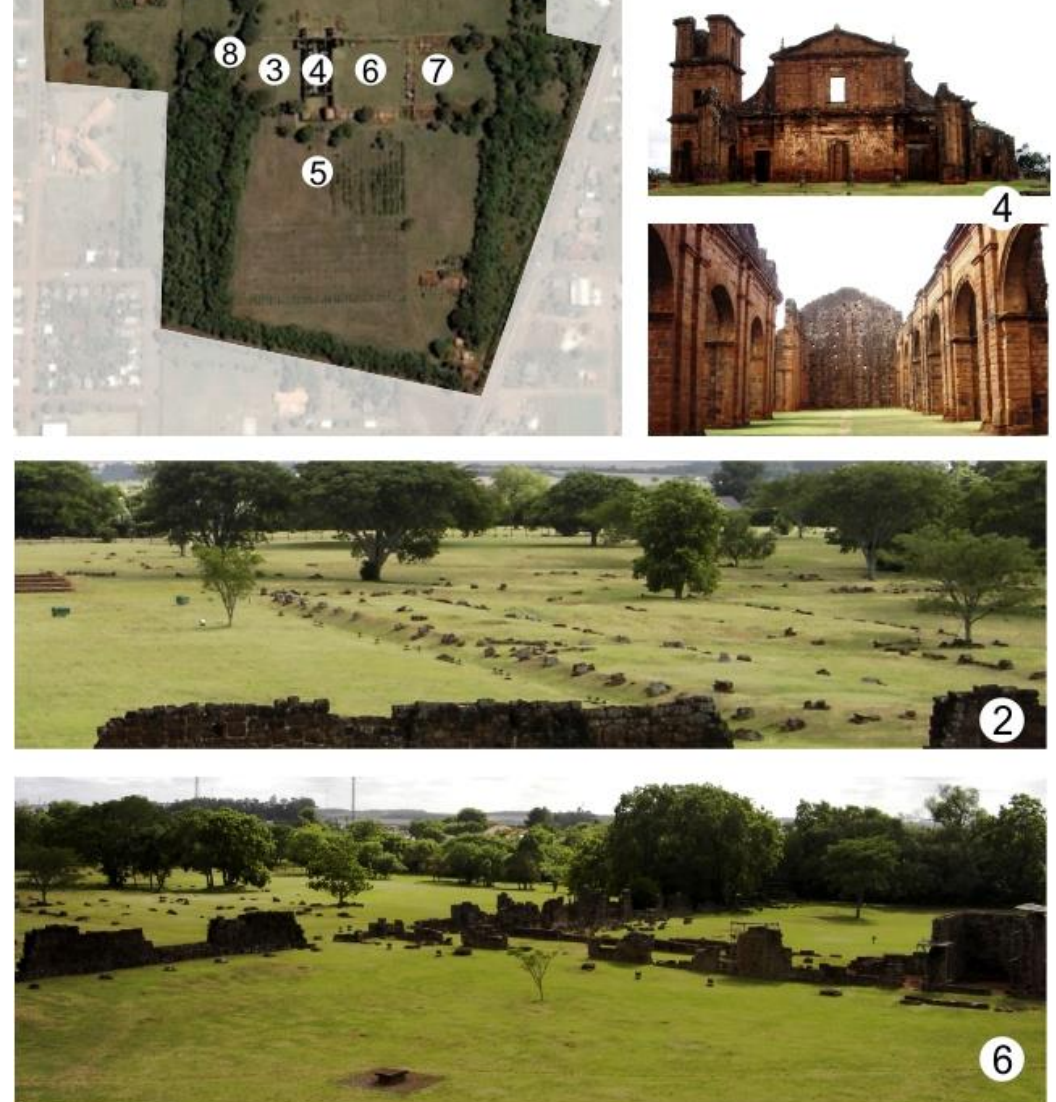

Figura 20. Ruínas em São Miguel Arcanjo - Brasil: 1. Praça, 2. Marcação das moradias, 3. Cemitério, 4. Igreja, 5. Quinta dos padres, 6. Pátio dos Padres, 7. Pátio das Oficinas, 8. Cotiguaçu. Fonte: Elaborada pela autora sobre imagem do Google Earth e com fotos da autora. 


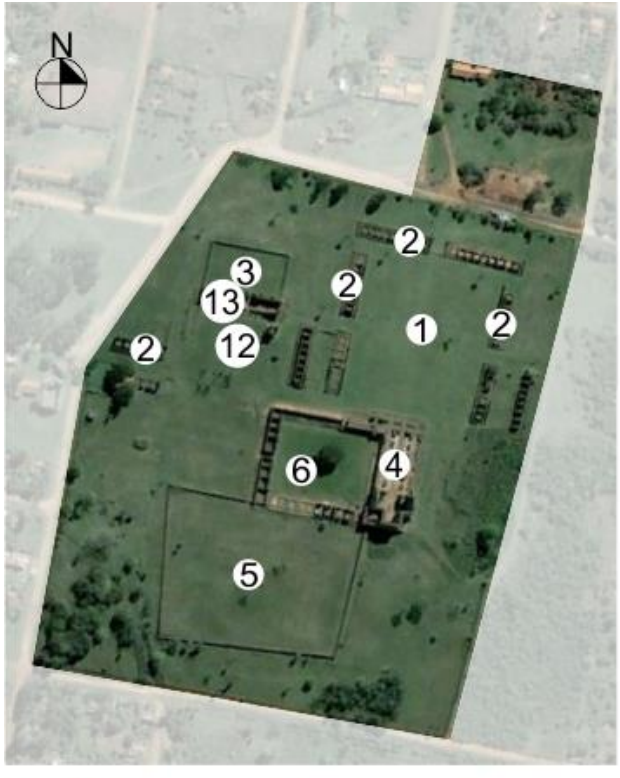

\section{SANTÍSIMA TRINIDAD \\ - PARAGUAI -}
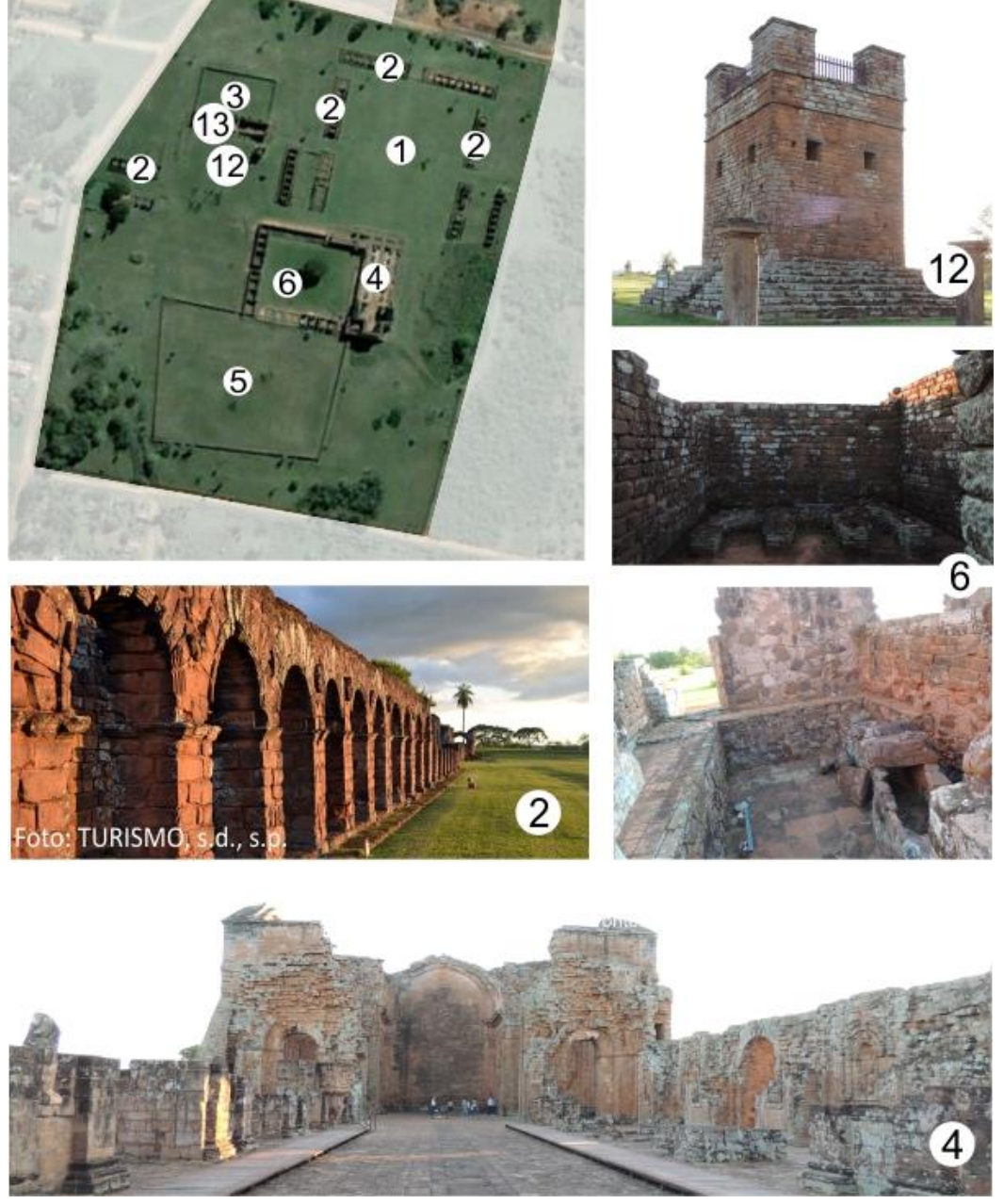

Figura 21. Ruínas em Santísima Trinidad - Paraguai: 1. Praça, 2. Moradias, 3. Cemitério, 4. Igreja, 5. Quinta dos padres, 6. Pátio dos Padres e das Oficinas, 12. Campanário, 13. Segunda igreja.

Fonte: Elaborada pela autora sobre imagem do Google Earth e com fotos da autora. 


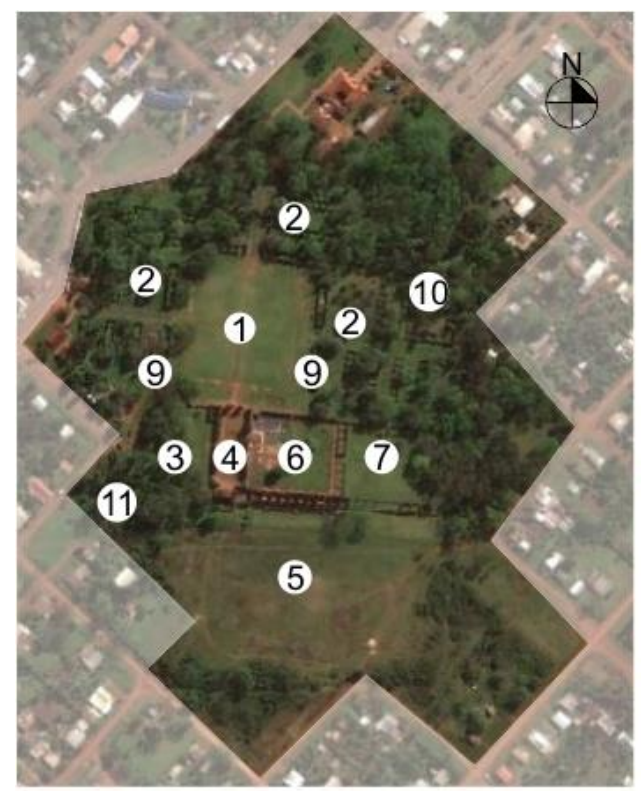

\section{SAN IGNÁCIO MINÍ \\ - ARGENTINA -}
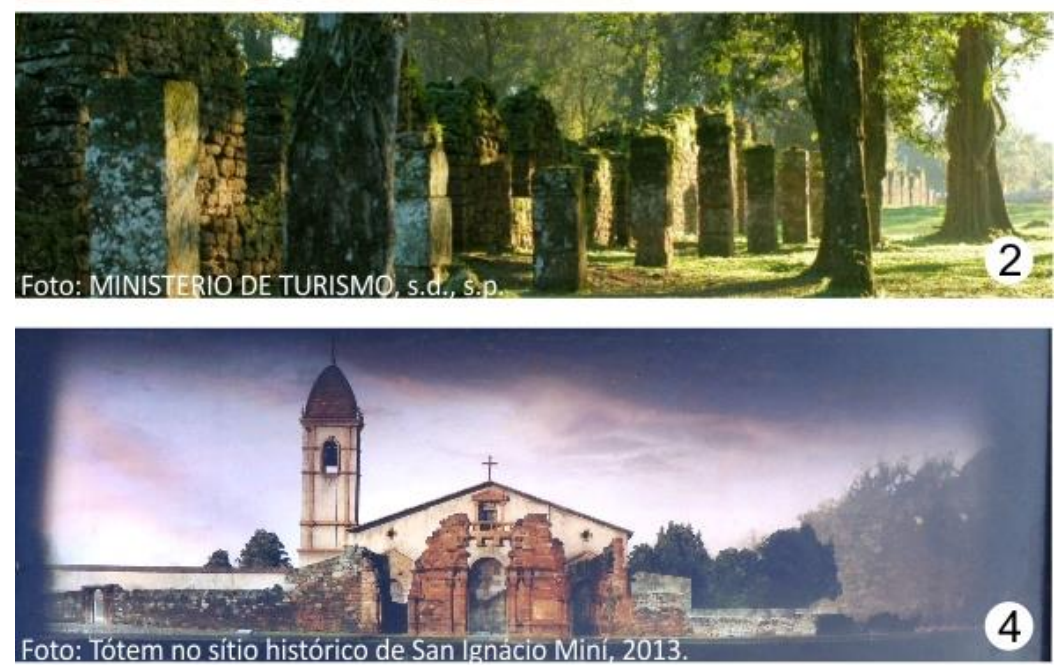

Figura 22. Ruínas San Ignácio Miní - Argentina: 1. Praça, 2. Moradias, 3. Cemitério, 4. Igreja, 5. Quinta dos padres, 6. Pátio dos Padres, 7. Pátio das Oficinas, 9. Cabildo, 10. Cadeia, 11. Hospital.

Fonte: Elaborada pela autora sobre imagem do Google Earth e com fotos da autora. 
Em relação a estas especificidades, São Miguel Arcanjo mantém a igreja melhor conservada, enquanto Santísima Trinidad conserva estruturas de uma segunda implantação e em San Ignácio Miní é possível apreciar de maneira mais completa o traçado urbano da missão. Além disso, algumas das edificações presentes nos três sítios históricos em análise constituem suas especificidades.

O grande vazio da praça (1), antigamente caracterizado como o centro da vida social da missão, ainda organiza edificações e atividades atuais nos três sítios, dentre elas as apresentações multimídias noturnas. Sua função original de amplificar o impacto de monumentalidade das edificações ainda persiste. Ao seu redor, em Trinidad e San Ignácio Miní ainda existem vestígios das paredes das moradias (2), enquanto o sítio histórico de São Miguel Arcanjo conserva apenas os desníveis no solo que marcam as ruas ${ }^{48}$. Como ressaltam Maeder e Gutiérrez (2010, p. 105), houve uma "[...] peculiar resposta arquitetônica das casas de índios de Trinidad, com suas arcadas de pedra formando o corredor perimetral das moradias". Algumas destas moradias estavam em uso até a década de 1940, mas “[...] apareciam totalmente abandonadas vinte anos mais tarde. Muitos desses conjuntos se desmoronaram parcialmente em época posterior [ao levantamento de Stelio Furlani, realizado em 1973,] [...] e alguns deles foram deficientemente reconstruídos" (MAEDER; GUTIÉRREZ, 2010, p. 102).

No eixo religioso, os sítios históricos ainda guardam demarcação murada do Cemitério (3). Já em relação às Igrejas (4), edificações de destaque em todas as Reduções pelo caráter religioso da ação da Companhia de Jesus, é interessante salientar o fato de que o arquiteto responsável pelo

\footnotetext{
${ }^{48}$ Nas antigas missões jesuíticas, as moradias eram construídas em nível mais alto que as ruas, a fim de evitar a entrada das águas das chuvas em seu interior.
} 
projeto e execução em São Miguel Arcanjo - Brasil, o padre italiano João Batista Primolí (Milão, 1679), também realizou as obras em Trinidad - Paraguai (ICOMOS, 1983, p. 2). Primoli foi auxiliado pelo projetista José Grimau, que, segundo o arquiteto brasileiro Fernando Machado Leal (1984, p. 79), construiu a cúpula de Trinidad e "desenhou a igreja de Jesus, também no Paraguai, iniciada em 1758".

Segundo o autor, as obras da igreja de São Miguel iniciaram-se em 1735, com duração de cerca de 20 anos. Atualmente mantém a fachada melhor conservada, mas foi completamente esvaziada de ornamentos ao longo de sua história. Enquanto isso, a igreja de Trinidad teve sua fachada destruída, mas mantém um grande número de ornamentos em suas paredes e também a pia baptismal, o púlpito (restaurado recentemente) e algumas estátuas.

Na Quinta dos padres (5) eram cultivadas e aclimatadas árvores frutíferas trazidas da Europa principalmente para o consumo dos padres, já que os indígenas não tinham muito apreço por frutas, legumes e verduras (BAPTISTA, 2009a). Trinidad e São Miguel por sua vez, mantêm uma demarcação murada deste espaço.

Trinidad é a única missão analisada em que o pátio dos padres (6) e o pátio das oficinas (7) constituem um único espaço, que reúne os aposentos dos padres, a cozinha e a caldeira de água que gerava vapor quente para o aquecimento dos cômodos dos padres no inverno (imagem (6) superior na Figura 21); as oficinas, dentre elas as responsáveis pela produção dos sinos (mesma imagem (6) inferior na mesma figura); as salas de aula; uma biblioteca; os armazéns e uma prisão (TURISMO, s.d., s.p.). Estes espaços com fins econômicos (armazéns, olarias, oficinas) ficavam próximos à Igreja para o controle dos padres e geralmente eram multifuncionais. 
São Miguel Arcanjo é a única missão analisada que apresenta ruínas do Cotiguaçu (8) (também chamado casa das mulheres), que abrigava viúvas, órfãos e mulheres cujos esposos ou pais estavam fora da missão. Enquanto isso, San Ignácio Miní apresenta edificações específicas com as funções de Cabildo ${ }^{49}$ (9) Cadeia $^{50}$ (10) e Hospital (11) ${ }^{51}$. Enquanto isso, Trinidad mantém uma espécie de segundo núcleo religioso, com um Campanário (12) e uma Segunda Igreja (13). Estas estruturas são motivo de dúvida em relação ao período de sua construção. Durante visitação guiada ao sítio, a pequena igreja e o campanário (Figura 21) são apresentados como construções da implantação provisória anterior à igreja principal. Contudo, Maeder e Gutiérrez (2010, p. 104) as identificam como posteriores à época jesuítica. Segundo Gutiérrez (2004), Trinidad sofreu um rearranjo: a igreja principal entrou em colapso em 1775 e então se construiu uma provisória no final do século XVIII. Portanto, tais estruturas foram construídas no período pós-jesuítico e não como antecessoras a uma igreja definitiva.

Patrimônio material móvel

Após a expulsão dos jesuítas em 1768, grande parte dos habitantes das Missões se instalou na Argentina ou no Paraguai, onde foram incorporados ao restante da população e contribuíram

\footnotetext{
${ }^{49}$ Em San Ignácio Miní, foram construídos dois Cabildos, um em cada lado da praça, sendo as edificações mais próximas da igreja, e diferenciados das moradias por sua configuração interna.

${ }^{50}$ Nas outras duas missões analisadas, havia um espaço destinado à prisão junto ao pátio das oficinas, tendo San Ignácio Miní a única edificação específica para esta função.

${ }^{51}$ Segundo Baptista (2009b, p. 89), nas missões, os hospitais não eram estruturas permanentes. De acordo com o autor, geralmente existiam pequenas enfermarias fixas.
} 
para a formação das culturas nacionais naqueles países. Já aqueles que permaneceram no Brasil, "[...] dispersaram-se pelo território do que veio a ser o Rio Grande do Sul e foram absorvidos posteriormente nas estâncias da Campanha Gaúcha [...]" (IBGE, 2006, p. 27). Abandonadas, as Reduções foram alvo de saques em busca dos lendários tesouros dos jesuítas e, como enfatiza Custódio (2014), principalmente de pilhagem de materiais de construção. Segundo Sustersic (1999), os ricos ornamentos das igrejas se perderam. O pouco resgatado pelos órgãos responsáveis foi reunido em museus nacionais, junto à missão mais bem conservada de cada país, para que, através da soma destas obras de arte e das profundas relações apresentadas entre elas, se pudesse representar e compreender esta cultura única.

Nesta pesquisa, entende-se como patrimônio material móvel o que Lisa Mazzola (2013), educadora de arte e diretora assistente no Museu de Arte Moderna de Nova lorque - MoMA, define como obra de arte: trabalhos de arte, escritos, partituras musicais, instrumentos e outros objetos ou artefatos significantes. Conceito adotado porque no contexto das Missões Jesuíticas foram produzidos objetos de diversas naturezas: mobiliário, prataria, imagem para culto, instrumentos musicais, etc., que foram fruto do diálogo entre as culturas indígena sul-americana e jesuíta espanhola. O talento do indígena para assimilar a arte, reproduzi-la e adaptá-la teve muitos e diversos produtos, que maravilharam o mundo. Uma produção artística que teve seu período áureo após o estabelecimento definitivo das Missões e o recuo dos bandeirantes (BOFF, 2006), e que produziu "representações pictóricas, esculturas, músicas, poesias, desenhos e artes superiores" (CABRAL et al, 1997, p. 42, tradução nossa ${ }^{52}$ ).

\footnotetext{
52 Do original em inglês: "[...] pictorial representations, sculptures, music, poetry, drawings and superior crafts [...]" (CABRAL et al, 1997, p. 42).
} 
Representações artísticas produzidas não necessariamente "para si ou para o outro, mas, sim, para a defesa do que há de sagrado no projeto missional" (BAPTISTA, 2009a, p. 61). Uma interação entre duas culturas, onde o método terreno aliou-se à espiritualidade. De modo que as expressões artísticas, especialmente as relacionadas à arquitetura e às ornamentações, foram ferramentas utilizadas para a reafirmação dos dogmas religiosos. A arte em si e o nível de aprimoramento possuíam a função de simbolizar o poder divino cristão no plano terreno. Neste fazer reúnem-se questões religiosas, artísticas e especialmente laborais em que o fazer estava intimamente ligado à opção religiosa do indivíduo: o longo processo de construção da igreja (símbolo maior da fé cristã inserida em meio ao território indígena) e as ornamentações (cujo trabalho minucioso refletia as habilidades indígenas e era um meio de catequização do indivíduo que produzia as peças e também dos demais por quem as imagens eram veneradas); o que favoreceu a incorporação da religião cristã entre os indígenas missioneiros.

A arte escultórica foi aquela que legou o maior número de exemplares aos tempos atuais, cujo testemunho é um relato não somente da técnica, mas especialmente da cultura que representam. Para a pesquisa, conservação e divulgação deste patrimônio móvel e também da cultura e história das Missões, os órgãos de preservação nacionais equiparam os sítios históricos com duas estruturas principais: museus e espetáculos noturnos.

Em São Miguel - Brasil (Figura 23, na próxima página), fora do perímetro cercado do sitio histórico há uma edificação que abriga a Secretaria de Turismo(1), uma livraria e exposições sobre as Missões Jesuíticas. No interior do sítio histórico, se encontra o Museu das Missões(3) e, junto a ele, a antiga Casa do Zelador(4), reformada na década de 1980 e atualmente reservada para o Instituto Brasileiro de Museus - IBRAM, que gerencia o Museu desde 2009, e a antiga sacristia (5). 


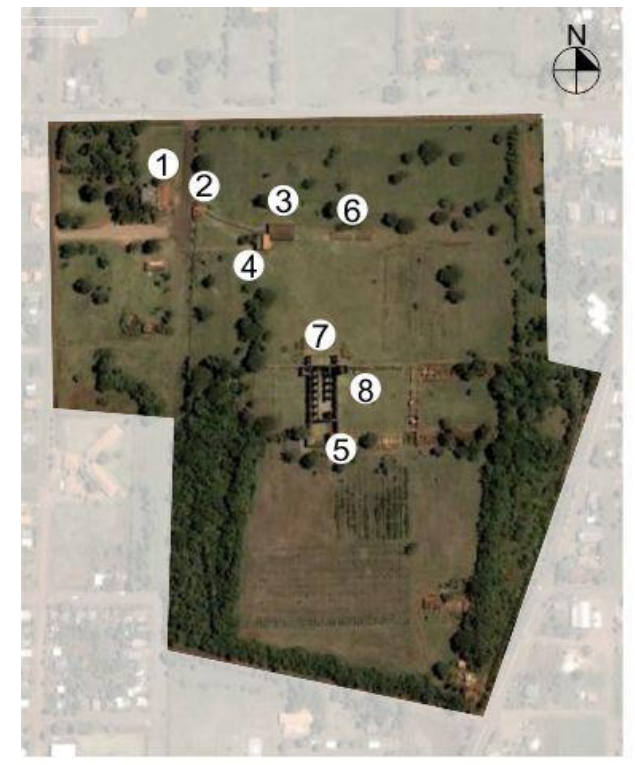

\section{SÃO MIGUEL \\ ARCANJO \\ - BRASIL -}
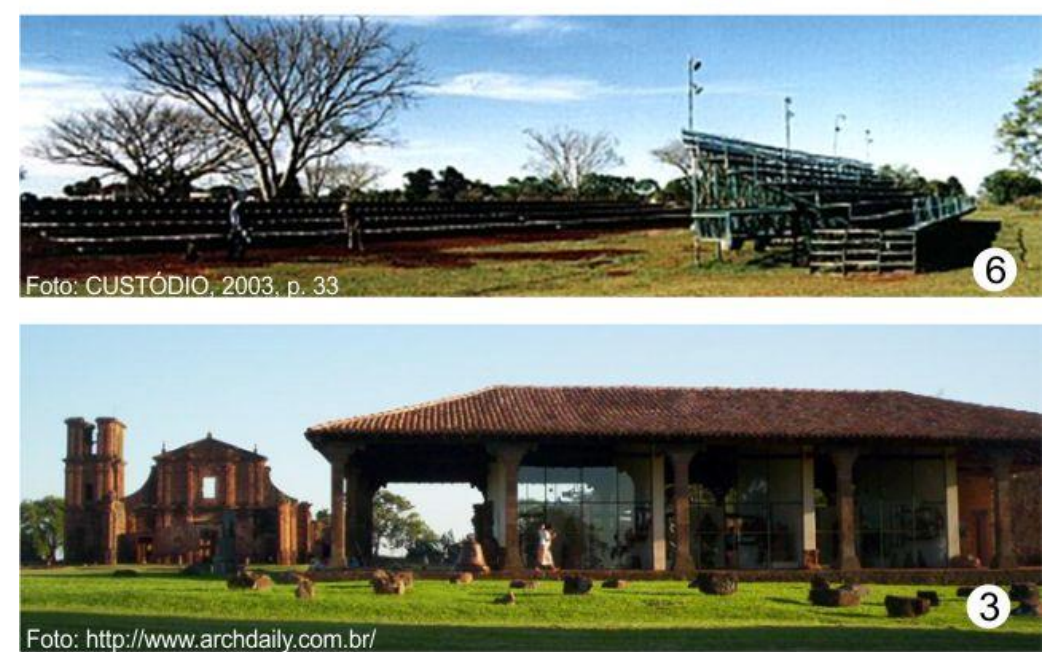

Figura 23. Estruturas do sítio histórico de São Miguel: 1. Secretaria Municipal de Turismo; 2. Entrada do sítio histórico; 3. Museu; 4. Antiga casa do zelador, atual IBRAM; 5. Espaço multimídia na antiga sacristia; 6 . Arquibancadas para o espetáculo noturno; 7. Spots de luz para o espetáculo noturno; 8. Trailer de comando do espetáculo noturno.

No topo à direita, esculturas em madeira policromada em exposição no Museu das Missões.

Fonte: Elaborada pela autora sobre imagem do Google Earth. 

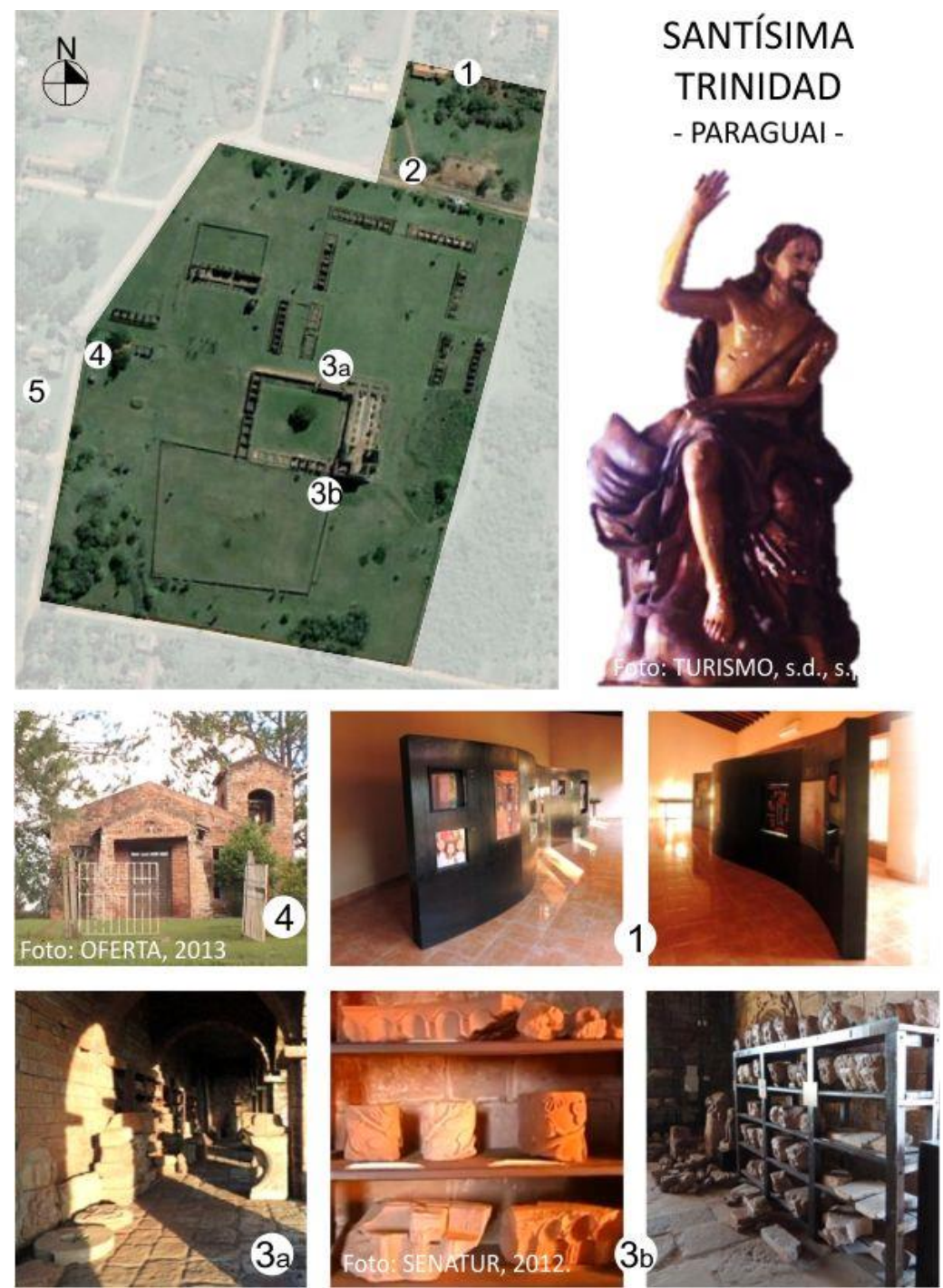

Figura 24. Estruturas do sítio histórico de Trinidad: 1 . Secretaria de Turismo; 2. Entrada do sítio histórico; 3a e 3b. Locais de exposição; 4. Antiga moradia reformada; 5. Igreja atual contendo imagens sacras como a mostrada no topo à direita. Fonte: Elaborada pela autora sobre imagem do Google Earth. 

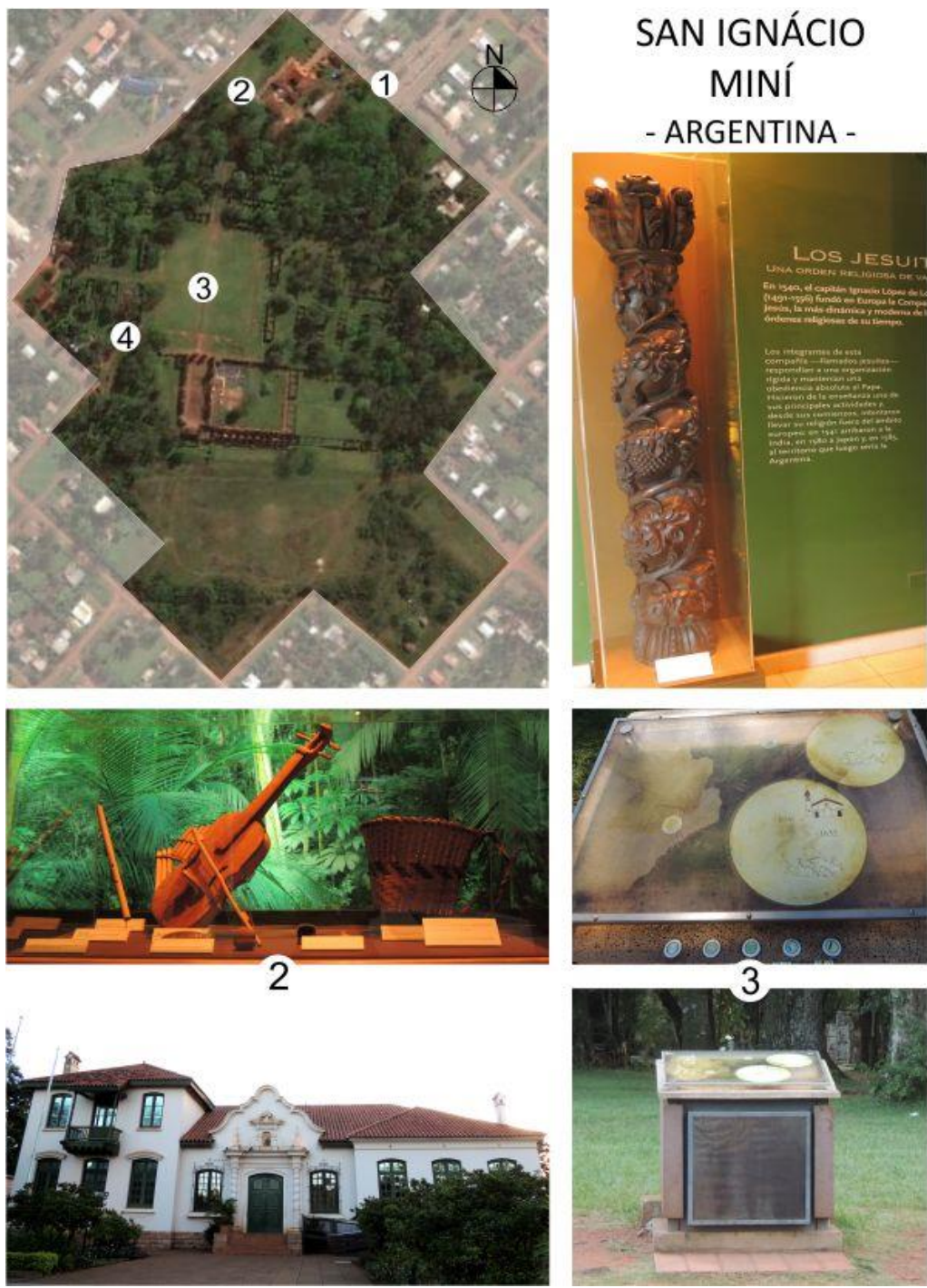

Figura 25. Estruturas do sítio histórico de San Ignácio Miní: 1. Entrada do sítio histórico; 2. Museu; 3. Totens informativos; 4 . Apoio ao visitante. No topo à direita, coluna em exposição no museu. Fonte: Elaborada pela autora sobre imagem do Google Earth, com fotos da autora. 
transformada em espaço para projeção multimídia. No sítio histórico, também está instalada a infraestrutura do espetáculo noturno: as Arquibancadas(6), que foram substituídas na década de 1990; os Spots de luz(7) junto à fachada da igreja e em outros pontos estratégicos, a Cabine de controle (8) e caixas de som próximas às arquibancadas.

No Paraguai, em Trinidad (Figura 24, na página 101), junto ao sítio histórico encontra-se o escritório técnico da Secretaria Nacional de Turismo - SENATUR(1), órgão nacional responsável pela administração do sítio. Ele está equipada com uma sala de projeção, onde apresenta um vídeo curto contando a história das Missões Jesuíticas da antiga República do Paraguai (SENATUR, 2012, s.p.), e uma sala com painel de exposição com conteúdo diverso sobre a missão de Trinidad. A entrada do sítio histórico(2) está posicionada em frente ao eixo monumental da missão, tendo como ponto central a fachada da igreja. Além disso, na antiga sacristia e em parte da circulação coberta interna ao pátio, existem dois locais de exposição(3) de diversas peças como anjos em pedra. Além disso, uma das moradias mais afastadas foi reformada e é utilizada como escola religiosa(4) pela comunidade; e várias imagens sacras missioneiras ainda são utilizadas em uma igreja(5) localizada ao lado do parque histórico. Tais imagens eram utilizadas onde atualmente funciona a escola religiosa e há alguns anos funcionava uma pequena igreja que não estava ligada ao passado da redução.

Na Argentina, em San Ignácio Miní (Figura 25, na página ao lado), o museu(2) apresenta diversos elementos da cultura missioneira conforme imagem no topo à direita da Figura 25 . Ao redor da praça central da missão, foram instalados totens(3) com informações sobre a história, a economia, a política e a cultura missioneiras, disponíveis em cinco idiomas: espanhol, inglês, português, italiano ou alemão. 


\section{Patrimônio imaterial}

O patrimônio imaterial missioneiro, história e cultura desta experiência histórica, é basicamente produzido por pesquisadores ligados às universidades dos países em que as Missões Jesuíticas se localizam. Este elemento foi extensamente tratado no Capítulo $1 \mathrm{com}$ a finalidade de apresentar o assunto desta pesquisa, mas cabe ressaltar que ele ainda é pouco divulgado inclusive em nível nacional. Segundo Sandra Petry (2013), chefe do escritório técnico do IPHAN de São Miguel, os órgãos responsáveis não possuem registro de todo o conhecimento produzido, mas sabem que pesquisas são realizadas em vários países. O que demonstra que atualmente a interação para troca de conhecimento entre os pesquisadores e os órgãos responsáveis ainda é insuficiente, embora a situação fosse diferente na década de 1990, como será tratado mais adiante no item 2.3.

\subsection{Patrimônio integrado}

A prevalência da atuação de órgãos nacionais sobre as questões legislativas relacionadas à preservação dos sítios históricos foi indicada pela Carta de Atenas, em 1931 (CARTA, 1931). Ao mesmo tempo, também foi sugerida a cooperação internacional e multidisciplinar, e a criação de organizações internacionais na área de restauro com caráter operativo e consultivo. Ações mais generalizadas, como a promoção de cursos internacionais de aperfeiçoamento para os profissionais ligados à preservação, ficam a cargo da UNESCO. Desse modo, a visão nacionalmente centralizada aplica-se às leis que amparam os monumentos, dando ao Estado o direito de decidir 
qual o seu destino, enquanto as ações de preservação e divulgação deveriam ser fruto de uma cooperação internacional, que é entendida nesta pesquisa como extremamente necessária para patrimônios compartilhados por nações, como é o caso das Missões Jesuíticas. Como mencionado, esta necessidade é entendida pelos profissionais e pelas instituições responsáveis pela preservação missioneira.

A arquiteta brasileira Ana Meira (2010, p. 1), salienta que, no Brasil,

Nós estamos acostumados a ver [...] a imagem das "ruínas de São Miguel" [...] como um dos símbolos mais representativos do Rio Grande do Sul. Geralmente nos lembramos de São Miguel e esquecemos os outros sítios que nos ajudam a entender a complexidade da experiência das missões jesuítico-guarani. [...]

Meira ainda enfatiza que os remanescentes materiais e imateriais e o patrimônio cultural das Missões no Brasil, no Paraguai e na Argentina se complementam. Nesta pesquisa entende-se que cada sítio histórico possui o potencial de representar uma parcela da história dos Trinta Povos e da Companhia de Jesus através dos vestígios materiais que abriga e da imaterialidade que representa, de modo que é necessário observá-los em conjunto para compor uma visão de sua constituição em termos históricos, sociais, econômicos e culturais, entre outros, como um quebra-cabeça histórico cujas peças precisam ser reunidas para dar forma à figura da experiência histórica que ocorreu entre os jesuítas e os indígenas desta região. Além dos elementos arquitetônicos e artísticos encontrados nos sítios, também são elementos importantes para seu entendimento os relatos históricos disponíveis em fontes bibliográficas ${ }^{53}$ e a cultura mantida pelos descendentes missioneiros.

\footnotetext{
${ }^{53}$ Que são organizadas em duas categorias, segundo o historiador argentino Alfredo Poenitz (2004), de acordo com a época em que foram escritas: as do período jesuítico e do pós-jesuítico.
} 

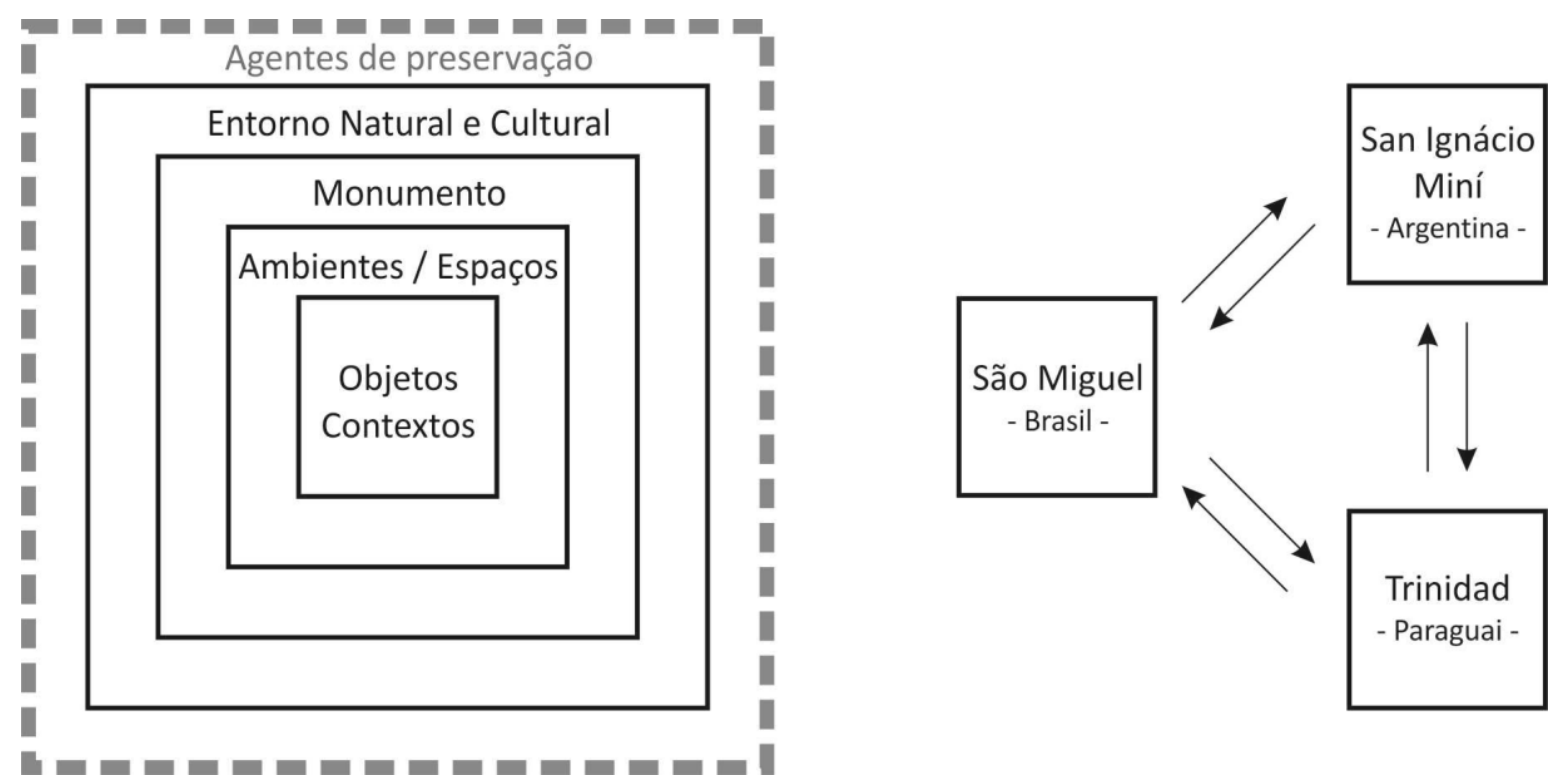

Figura 26. Sistema das Missões Jesuíticas Guarani, mostrando os diversos elementos envolvidos em cada sítio histórico (à esquerda) e as relações entre os três principais sítios históricos (à direita). Fonte: MUJICA, 2004b, p. 18, tradução nossa. 
Ainda é preciso criar "[...] uma viva interligação entre homens e estruturas, uma verdadeira sinergia onde ambas as partes só existem por se contatarem, como que uma assegurando a existência da outra" (BAPTISTA; SANTOS, 2009, p. 7). Um ambiente em que a comunidade regional se aproprie da história e da identidade que são suas e onde a comunidade mundial tenha a possibilidade e o anseio de refletir sobre esta experiência e aprender com ela. Isto porque este é um patrimônio compartilhado que simboliza uma história e uma herança cultural em comum, "um elemento fundamental na consolidação da identidade regional" (BARBACCl; GREMENTIERI, 2004b, p. 20). Territórios físicos e objetos de concretude material que intermediam o entendimento sobre um período histórico distinto e suas contribuições para as sociedades nacionais atuais. O patrimônio histórico visto como a união das "dimensões múltiplas da cultura como imagens de um passado vivo: acontecimentos e coisas que merecem ser preservadas porque são coletivamente significativas em sua diversidade" (PAOLI, 1992, p. 25).

Mujica (2004b, p. 18) apresenta um diagrama do que considera o sistema jesuítico guarani (Figura 26, na página ao lado), segundo o qual cada missão engloba quatro níveis de elementos que são entendidos por esta pesquisa da seguinte forma: o mais interno, chamado pelo autor de objetos e contextos, envolve o patrimônio móvel missioneiro composto basicamente por estátuas de madeira e instrumentos musicais e a imaterialidade que representam (história e cultura); que estão inseridos no nível ambientes ou espaços. Este segundo nível engloba os museus, que abrigam os elementos do nível anterior e estão localizados junto às ruínas das Reduções Jesuíticas e tem a função de demonstrar o elo entre o material e o imaterial. Este conjunto de ruínas e museus forma os monumentos históricos, que esta pesquisa entende como os parques históricos nacionais. No último nível está o entorno natural e cultural de cada uma das Missões, que se 
refere tanto ao ambiente físico geográfico e urbano em que os parques se inserem, quanto às relações culturais mantidas com a comunidade.

É possível perceber uma relação de dependência entre os remanescentes dos sítios históricos no que concerne ao entendimento dos diversos aspectos desta experiência histórica. Por exemplo, em relação à arquitetura jesuítico-guarani, por seu estado de ruínas, é necessário observar um conjunto de Missões Jesuíticas a fim de desenvolver um entendimento sobre como eram as estruturas edificadas e os ornamentos e estatuárias. E, um nível acima desta compreensão sobre os aspectos materiais, há o âmbito sociocultural, que somente pode ser entendido quando todos os elementos materiais e imateriais são reunidos e interligados.

Embora o diagrama de Mujica apresente apenas três sítios históricos (os mesmos analisados nesta pesquisa), este sistema maior e suas relações devem ser pensados para todas as Missões. De modo que é preciso entender que cada uma delas constitui em si um subsistema dentro do sistema maior denominado Trinta Povos das Missões. Cada missão jesuítica constitui em si um sistema composto por diversos elementos e estes possuem relação com seus semelhantes nas demais Missões, de modo que a rede de relações deste tapete é ainda mais entrelaçada. Por exemplo, cada Redução possui elementos arquitetônicos únicos que podem ser comparados aos de outras para traçar um panorama da tipologia construtiva missioneira. Da mesma forma, cada missão possui remanescentes artísticos diferenciados que devem ser reunidos para delinear as características das artes missioneiras. Se forem analisados os diversos níveis de elementos contidos em cada Missão segundo Mujica (2004b), percebe-se que a quantidade de fios e interações do sistema jesuítico é ainda maior, multiplicando-se incalculavelmente e unindo-se para formar uma imagem cada vez mais completa e compreensível do fenômeno histórico 
missioneiro, que só pode ser compreendido através dos vestígios materiais e imateriais preservados por ser um período histórico finalizado e uma sociedade já extinta.

Nas palavras dos geógrafos brasileiros Christiano Ricardo dos Santos e Aldomar Arnaldo Rückert (2012, p. 10): “O valor do patrimônio jesuítico-guarani está na combinação das características materiais dos bens, na geografia cultural gerada e na integração de vários países, na medida em que compartilham um processo histórico particular e único. [...]”. Este patrimônio não pode ser definido como pertencente a apenas um destes países, pois perpassa as fronteiras e as distâncias físicas, e expõe as bases compartilhadas de suas formações como Estados. Complementariedade percebida nos dias atuais e tão intensa que J. L. Luxen (apud ROJAS-SOLA; CARRANZA-CAÑADAS, 2011, p. 74, tradução nossa ${ }^{54}$ ), secretário geral do ICOMOS, afirma que

a distinção entre patrimônio físico e patrimônio cultural é artificial. O patrimônio físico só alcança seu significado verdadeiro quando lança luz sobre seus valores subjacentes. Por outro lado, o patrimônio intangível deve tomar corpo em manifestações tangíveis, em símbolos visíveis, se for para ser conservado.

Esta pesquisa entende que é essencial adicionar ainda um nível mais externo ao diagrama de Mujica (tracejado na figura), que represente a dimensão humana dos processos existentes entre os níveis de Mujica, que é composto por: órgãos responsáveis, pesquisadores acadêmicos, guias de turismo e comunidade. Estes elementos humanos são considerados os principais agentes preservacionistas, já que cabe a eles incentivar e realizar as interações atuais entre o conteúdo de

\footnotetext{
${ }^{54}$ Do original em inglês: "[...] the distinction between physical heritage and intangible heritage is artificial. Physical heritage only attains its true significance when it sheds light on its underlying values. Conversely, intangible heritage must be made incarnate in tangible manifestations, in visible signs, if it is to be conserved" (LUXEN apud ROJAS-SOLA; CARRANZA-CAÑADAS, 2011, p. 74).
} 


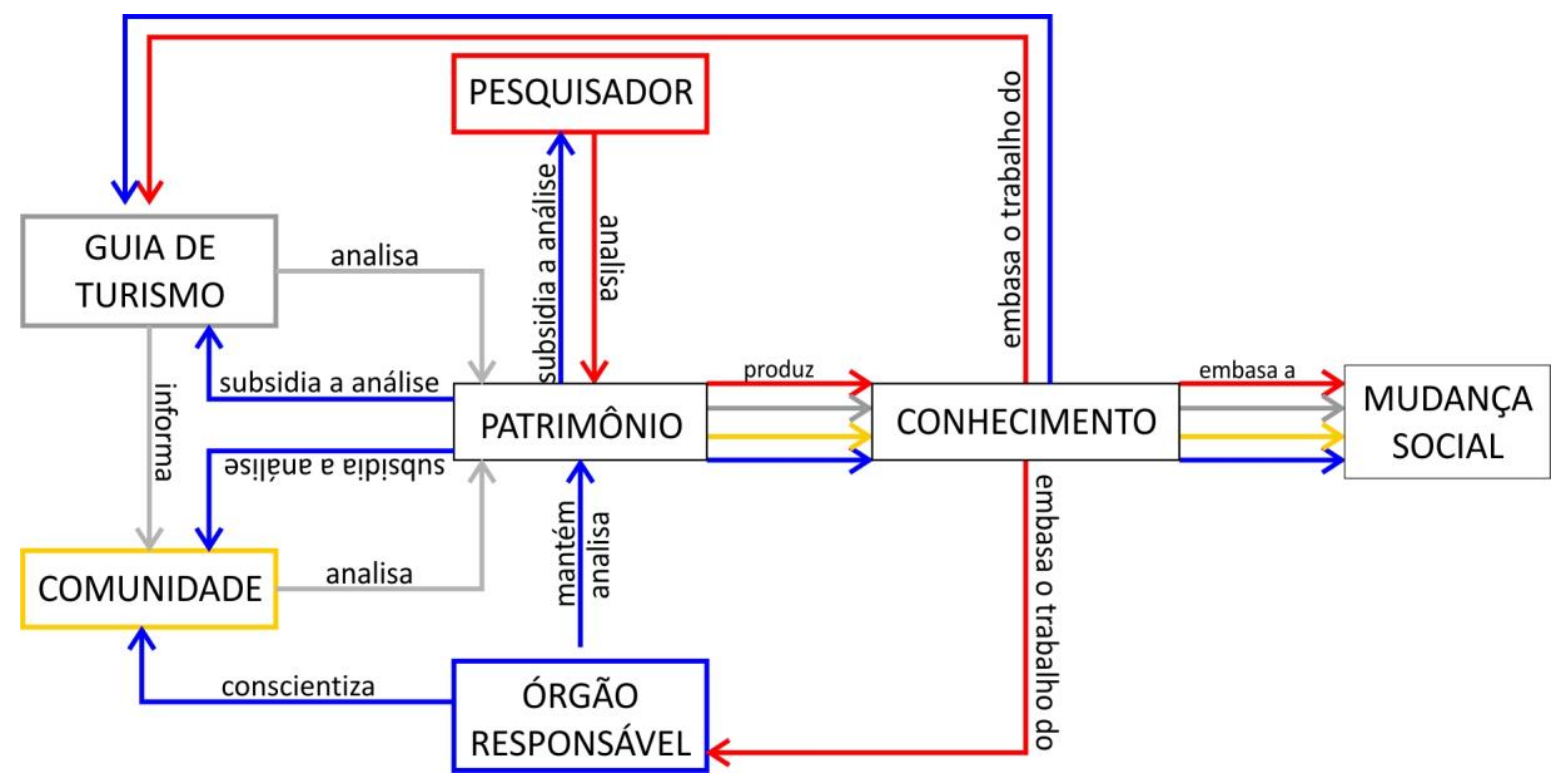

Figura 27. Interações entre os agentes envolvidos na preservação, possibilitadas pelo patrimônio. Fonte: Elaborada pela autora.

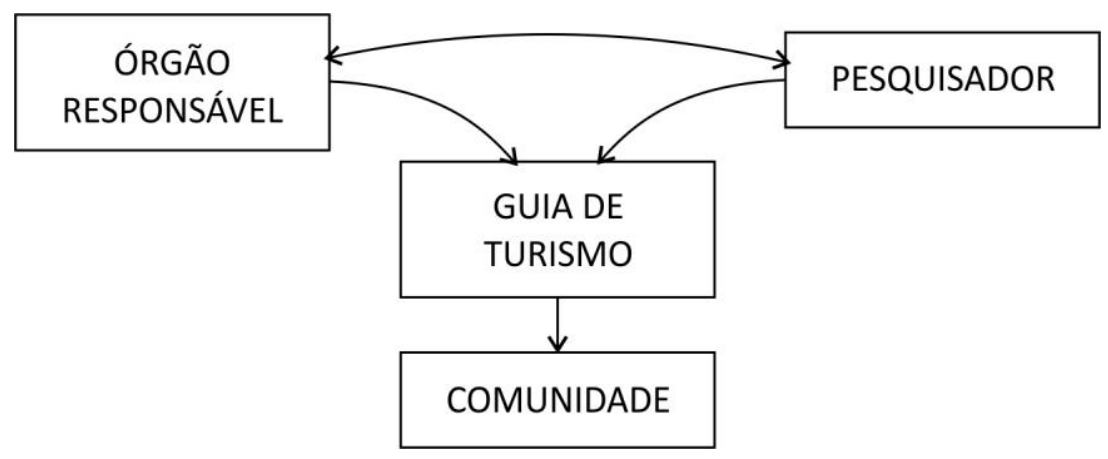

Figura 28. A importância do guia de turismo no sistema de comunicação das Missões Jesuíticas. Fonte: Elaborada pela autora. 
cada sítio histórico e entre todos eles.

Analisando a Figura 27, na página ao lado, percebe-se que o sistema de preservação dos sítios históricos constitui um sistema de intensa interdependência entre os elementos humanos, onde cada agente dá suporte para a ação dos demais. Além disso, em uma análise mais aprofundada, nota-se que o patrimônio depende imensamente destas interações e vice- versa. Isso porque, se não houver patrimônio, não são realizadas as interações. E acima de tudo, se os agentes não sentirem a necessidade de existência deste patrimônio, se não o valorizarem, não há necessidade de preservá-lo.

Neste ponto de congruência entre aspectos físicos (bens patrimoniais) e humanos (agentes), percebe-se a importância da conscientização da comunidade e esta ação como finalidade dos trabalhos dos agentes. E, neste contexto, a importância da formação de guias de turismo beminformados é essencial para o funcionamento do sistema, já que este profissional é o elo entre todos os agentes deste sistema (na Figura 28, na página ao lado). Ele reúne o conhecimento produzido pelos pesquisadores e pelos órgãos responsáveis e o repassa para a comunidade.

\section{Ações integradas de preservação das Missões Jesuíticas}

Além de preservar em cada país os remanescentes singulares desta experiência histórica, é essencial para o pleno entendimento das Missões Jesuíticas que as ações de preservação sejam realizadas internacionalmente de modo a garantir ao observador uma visão mais completa, como discutido anteriormente. 


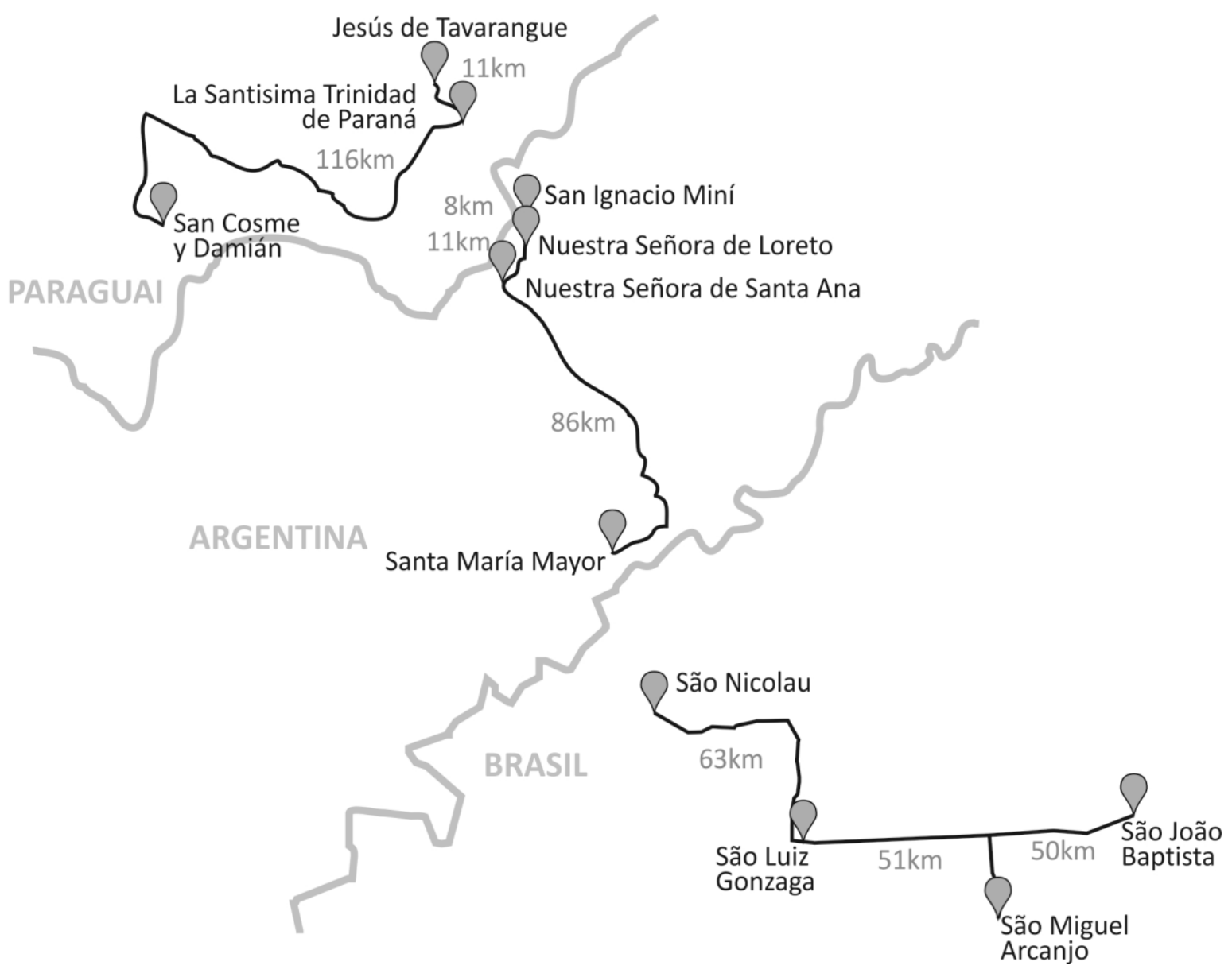

Figura 29. Rotas Jesuíticas incentivadas pelos governos paraguaio e argentino. Fonte: Elaborada pela autora. 
Neste sentido, algumas ações já são realizadas no Paraguai e na Argentina através do incentivo à visitação de uma rota missioneira nacional (Figura 29, na página ao lado) por meio da venda de ingresso único para as Missões de cada país ${ }^{55}$. O que demonstra a consciência que os países possuem sobre a importância do conjunto das Missões. Contudo, os órgãos nacionais envolvidos necessitam de ações integradas voltadas não somente à conservação e divulgação turística de seus sítios nacionais, mas também à efetivação do já criado Circuito Internacional das Missões e da divulgação do patrimônio de forma mais completa, através da qualificação de profissionais e da diversificação das experiências criadas.

Esta necessidade de preservação e divulgação integradas já é reconhecida internacionalmente desde a inclusão de algumas Reduções na Lista do Patrimônio Mundial. Na década de 1980, o Comitê do Patrimônio Mundial ressaltava a importância que o conjunto das Missões Jesuíticas possui como melhor maneira de representá-las. Cerca de uma década depois, a UNESCO retrata o andamento dos trabalhos de restauração nacionais, explicando que naquela época:

[...] A restauração bem-sucedida das Missões em território brasileiro estavam quase completas. Em relação às missões argentinas, as atividades de restauração tem foco em uma missão, San Ignácio Miní. Uma abordagem mais global foi recomendada, assim como o aumento da cooperação sub-regional. A Delegação Brasileira informou ao Comitê que passos em direção a tal cooperação já foram tomados pelos países do MERCOSUL (Argentina, Brasil, Uruguai e Paraguai) (UNESCO, 1993, s.p., tradução nossa ${ }^{56}$ ).

\footnotetext{
${ }^{55}$ No Brasil, somente o sítio histórico de São Miguel possui a infraestrutura de bilheteria. Nos demais sítios brasileiros não é cobrado ingresso para visitação.

${ }^{56}$ Do original em inglês: “[...] The successful restoration of the Missions on Brazilian territory was almost completed. Regarding the Argentina missions, restoration activities have focused on one mission, San Ignácio Mini. A more global
} 
De acordo com Santos e Rückert (2012, p. 11), a mobilização internacional em relação ao turismo na região das Missões aconteceu antes mesmo de sua inclusão na Lista do Patrimônio Mundial. Segundo eles, na década de 1970 uma comissão foi formada por Argentina, Brasil e Paraguai para alavancar o desenvolvimento integrado desta região em conjunto com as Missões, teve como consequência algumas ações entre o final dos anos 1980 e o início dos anos 1990. Neste contexto, em 26 de março de 1991, Argentina, Brasil, Paraguai e Uruguai assinaram o Tratado de Assunção, criando o Mercado Comum do Sul - MERCOSUL, quando

[...] foram realizados estudos conjuntos visando implementar o turismo no âmbito do mercado comum [...]. [inclusive uma] Rede de Cooperação Técnica para a Roteirização, [...] [que] tem como objetivo consolidar o Circuito Internacional das Missões Jesuíticas Guarani através da construção de parcerias, promoção da integração e compromisso dos envolvidos, adensamento dos negócios na região, inclusão social, resgate e preservação dos valores culturais e ambientais e o aumento de investimentos e serviços ofertados na região. [...] (SANTOS; RÜCKERT, 2012, p. 12-13).

O jornalista argentino Jorge Telerman (2000, p. 13, tradução nossa ${ }^{57}$ ) acrescenta que, em um encontro do Mercosul, enfatizou-se que "A construção de um espaço comum implica o reconhecimento do outro como parte de um todo, que se enriquece na diversidade e no pleno desenvolvimento das identidades locais". Neste contexto de ações conjuntas, o Circuito Internacional das Missões Jesuíticas é uma importante iniciativa, que abrange as seis Reduções Jesuíticas incluídas na Lista do Patrimônio Mundial da Humanidade, nos três territórios nacionais, em um raio de 500km. De acordo com a turismóloga brasileira Ana Biesek (2009, p. 10),

approach was recommended as well as increased sub-regional cooperation. The Brazilian Delegation informed the Committee that steps towards such cooperation were already being taken by the countries of MERCOSUR (Argentina, Brazil, Uruguay and Paraguay)" (UNESCO, 1993, s.p.).

${ }^{57}$ Do original em espanhol: "La construcción de un espacio común implica el reconocimiento del otro como parte de un todo, enriqueciéndose éste en la diversidad y el pleno desarrollo de las identidades locales” (TELERMAN, 2000, p. 13). 
Tendo como cenário terras argentinas, brasileiras e paraguaias, o Roteiro Iguassu Misiones [Figura 30, na próxima página] é o primeiro roteiro turístico do Mercosul. [...] O turismo é uma alternativa importante para o desenvolvimento integrado deste território, uma vez que a região é considerada como um dos principais corredores histórico-culturais internacionais do mundo [...].

A geógrafa brasileira Carmen Nogueira (2000, apud CARNEIRO FILHO; SANTOS, 2012, p. 161) enumera as principais dificuldades de desenvolvimento da região: 1. Carência de profissionais qualificados, que são os agentes de informação dos visitantes, tendo papel fundamental nos processos de contextualização e enriquecimento dos bens patrimoniais; 2. Desconhecimento da história, o que gera o descaso da população em relação a seu próprio patrimônio e identidade; 3. Ausência de maior diversidade de atrativos, o que reduz o número de visitantes; 4. Desconhecimento dos idiomas da região (espanhol no Brasil, e português nos demais países), o que desestimula o intercâmbio entre os países do próprio conjunto das Missões Jesuíticas; e 5. Precariedade de infraestrutura turística, dentre elas, sinalização, hotéis e restaurantes. Além disso, diversas outras questões administrativas e políticas atrasam o estabelecimento da rota turística e o desenvolvimento turístico da região.

Os geógrafos brasileiros Camilo Carneiro Filho e Christiano Ricardo dos Santos (2012, p. 159) ainda acrescentam a esta lista as barreiras impostas pelas legislações nacionais e o fato de que "A Região Missioneira é carente de pontes, rodovias e aeroportos - equipamentos fundamentais para o crescimento da atividade turística". Talvez parte desses problemas se deva ao fato de esta proposta de rota turística ser constituída por cidades pequenas (Figura 31, na página 118).

De acordo com o chefe do escritório de Trinidad - Paraguai, Edgar Parede (2013, s.p.), existe a intenção de construir uma nova ponte internacional ligando Trinidad - Paraguai, a San Ignácio Miní - Argentina, para possibilitar uma rota integrada entre as Reduções destes dois países. 


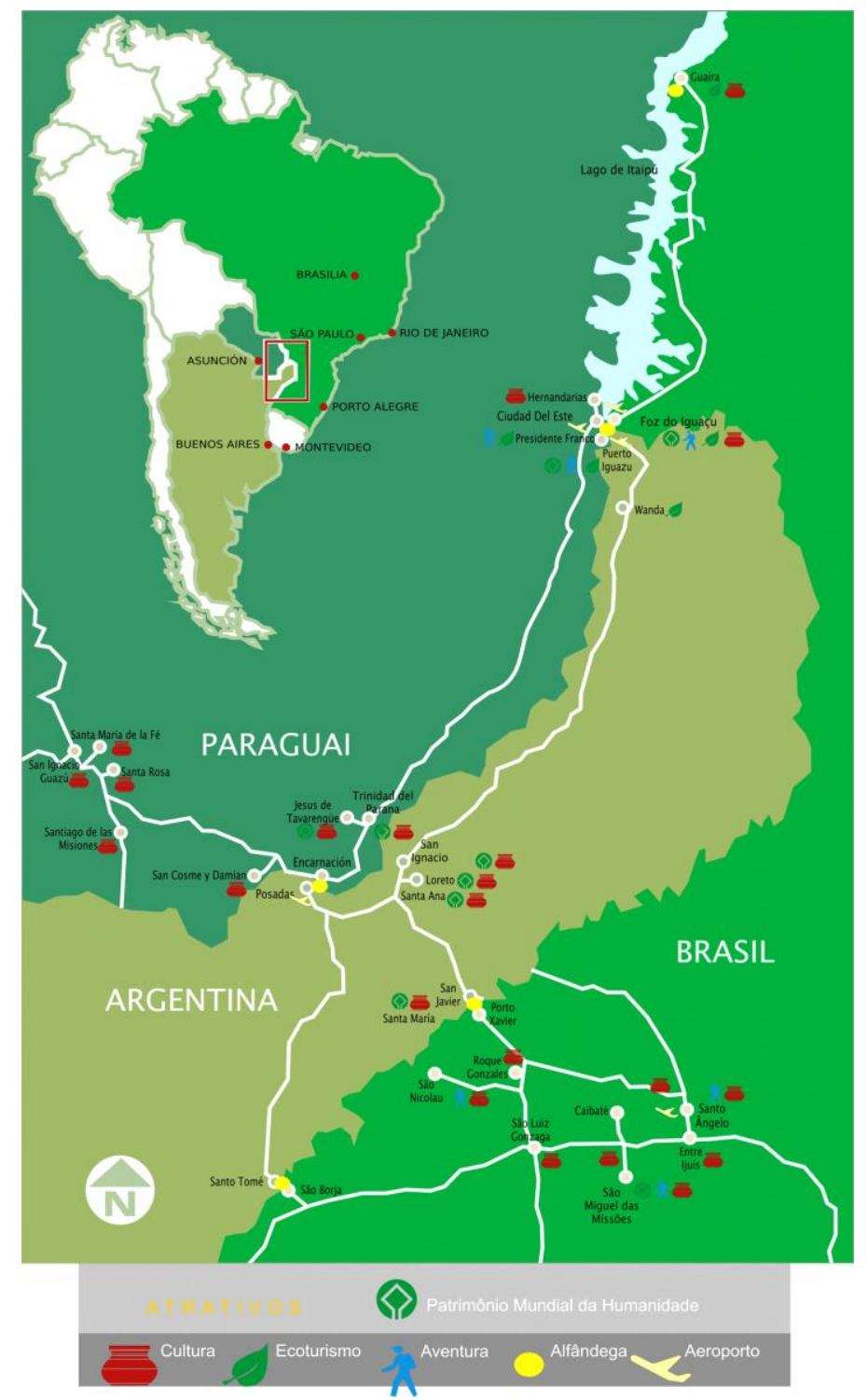

Figura 30. Roteiro Iguassu-Misiones.

Fonte: http://www.rotamissoes.com.br/_portugues/oQueAtrativoslguassu.php. 
Contudo, tal projeto ainda está em processo de análise pelas autoridades e é dificultado pela necessidade de criação de uma nova alfândega. As ações nacionais são marcadas por muitos entraves burocráticos e movidas pelo esforço e afeto dos profissionais ligados a elas. Segundo a chefe do escritório técnico de São Miguel - Brasil, Sandra Petry (2013, s.p.), trabalha-se atualmente o nivelamento inicial das instituições, para posteriormente serem retomados os trabalhos de implementação de uma rota turística internacional das Missões. Já a chefe da Direção de Planificação de Misiones-Argentina, Myriam M. Ayala (2013, s.p.), enfatiza que atualmente os projetos integrados mais significativos ocorrem, sobretudo, nas Universidades no âmbito da pesquisa.

Segundo Custódio (2004b, p. 39), antes da estruturação do Mercosul, "técnicos de diferentes setores da área da cultura já buscavam a integração e o intercâmbio". Quatro anos após a criação do Mercosul, em 1995, foi criada a Comissão Técnica do Patrimônio do Mercosul, que reúne representantes técnicos dos países envolvidos e se dedica "à análise de ações conjuntas de reconhecimento, proteção, conservação e valorização do patrimônio cultural do Mercosul, à preservação do patrimônio arqueológico pré-colombiano e à valorização do patrimônio intangível constituído por idiomas, tradições e costumes desses países" (IPHAN, 2008, s.p.). Nas diversas reuniões realizadas entre 1995 e $2008^{58}$, segundo Custódio (2002b), os envolvidos buscaram compatibilizar informações e legislações, realizaram capacitação técnica e trataram de temas como o turismo cultural e o dia do patrimônio.

\footnotetext{
${ }^{58}$ A última menção às reuniões da Comissão encontrada no site do IPHAN data de 2008. Não se sabe se ocorreram posteriores.
} 


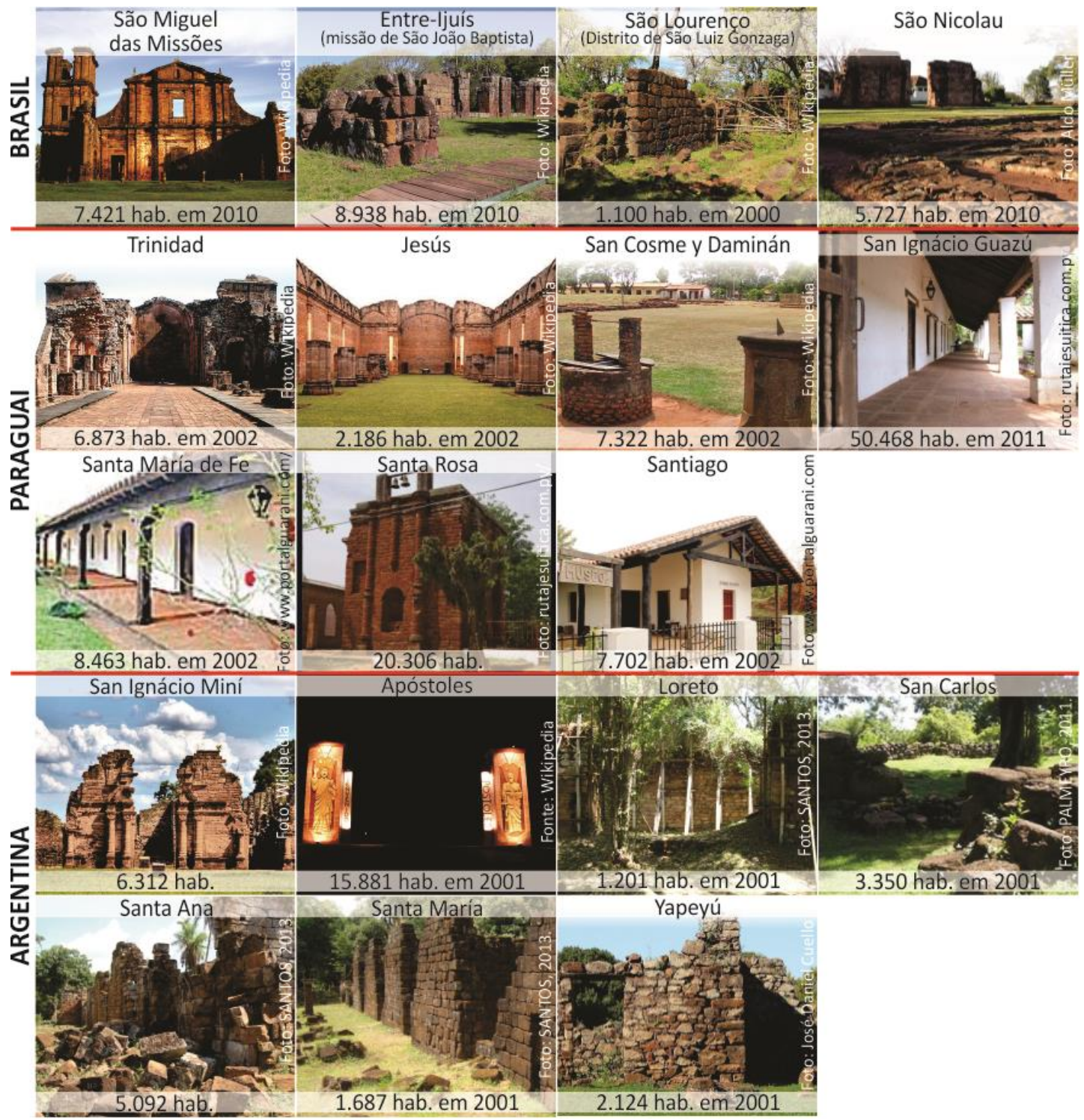

Figura 31. Dados das cidades que ainda possuem sítios históricos, de acordo com Stefano (1997). Fonte: Elaborada pela autora com dados da Wikipédia (Créditos nas fotos). 
Tais esforços culminaram na realização do "Programa de Capacitação para a Conservação, Gestão e Desenvolvimento Sustentável das Missões Jesuíticas dos Guarani”, em São Miguel das Missões, entre os anos de 2000 e 2003. O evento foi composto por um Curso-Oficina de Conservação, Gestão e Desenvolvimento Sustentável das Missões Jesuíticas dos Guarani e por um curso de Prática de Metodologias em Conservação e com a participação de diversos profissionais ligados aos órgãos de preservação dos países envolvidos (WORLD MONUMENTS FUND, 2004). Neste momento, foi possível compartilhar o conhecimento produzido no Brasil, país onde a questão da preservação das Missões está mais adiantada pela longa trajetória do IPHAN (CUSTÓDIO, 2014).

\subsection{Agentes nacionais e interações}

Os órgãos envolvidos com a salvaguarda das Missões Jesuíticas podem ser divididos em quatro instâncias: internacionais, nacionais, estaduais ou provinciais, e municipais (Tabela 2, na próxima página). Entre os internacionais, se destacam a UNESCO ${ }^{59}$, o Fundo do Patrimônio Mundial $^{60}$, o Conselho Internacional de Monumentos e Sítios ${ }^{61}$ e o Conselho Internacional de Museus ${ }^{62}$.

\footnotetext{
${ }^{59}$ Site: www.unesco.org

${ }^{60}$ World Monuments Fund - Site: www.wmf.org

${ }^{61}$ Site: http://www.icomos.org.br/

${ }^{62}$ Site: http://icom.museum/the-committees/international-committees/
} 


\section{- INTERNACIONAL -}

\begin{tabular}{|c|c|c|c|}
\hline UNESCO & WMF & ICOMOS & ICOM \\
\hline $\begin{array}{c}\text { Organização das } \\
\text { Nações Unidas para } \\
\text { a Educação, a Ciência } \\
\text { e a Cultura }\end{array}$ & $\begin{array}{l}\text { Fundo Mundial } \\
\text { do Patrimônio }\end{array}$ & $\begin{array}{c}\text { Conselho Internacional } \\
\text { de Monumentos } \\
\text { e Sítios }\end{array}$ & $\begin{array}{c}\text { Conselho } \\
\text { Internacional de } \\
\text { Museus }\end{array}$ \\
\hline
\end{tabular}

\begin{tabular}{|c|c|c|c|}
\hline Nível / País & - BRASIL - & - PARAGUAI - & - ARGENTINA - \\
\hline Nacional & $\begin{array}{l}\frac{\text { MinC }}{\text { Ministério da Cultura }} \\
\underline{\text { IPHAN }} \\
\text { Instituto do } \\
\text { Patrimônio Histórico e } \\
\text { Artístico Nacional } \\
\text { InRAM } \\
\text { Instituto Brasileiro de } \\
\text { Museus }\end{array}$ & $\begin{array}{l}\text { SENATUR } \\
\frac{\text { Secretaría Nacional de }}{\text { Turismo }}\end{array}$ & $\begin{array}{c}\text { Comisión Nacional de } \\
\text { Museos, Monumentos } \\
\text { y Lugares Históricos }\end{array}$ \\
\hline $\begin{array}{l}\text { Estadual / } \\
\text { Provincial }\end{array}$ & - & - & $\begin{array}{l}\text { Subsecretaría de } \\
\text { Gestión Estratégica de } \\
\text { la provincia de } \\
\text { Misiones }\end{array}$ \\
\hline Municipal & $\begin{array}{l}\text { Secretaria Municipal } \\
\text { de Turismo de São } \\
\text { Miguel das Missões }\end{array}$ & - & - \\
\hline
\end{tabular}

Tabela 2. Órgãos relacionados à preservação das Missões Jesuíticas. Fonte: Elaborada pela autora. 
No Brasil, o Instituto do Patrimônio Histórico e Artístico Nacional - IPHAN ${ }^{63}$ é responsável pela administração do chamado Parque Histórico Nacional das Missões (que envolve quatro sítios históricos que estão sob a tutela da União: São Miguel das Missões, São Nicolau, São Luiz Gonzaga e São João Baptista), pela promoção de a programas de educação patrimonial e pela supervisão arqueológica permanente (conservação das estruturas e manutenção do parque) (SOUZA, 2004; PETRY, 2013). Por ser ligado ao Ministério da Cultura, atualmente possui caráter cultural e não desenvolve atividades relacionadas ao turismo; o que, segundo Petry (2013), é realizado pela Secretaria Municipal de Turismo de São Miguel. No ano de 2009 foi criado o IBRAM ${ }^{64}$ - Instituto Brasileiro de Museus, que passou a ser responsável pela manutenção do Museu das Missões. Não há participação de órgãos estaduais, no Brasil. No Paraguai, a SENATUR - Secretaria Nacional de Turismo é o órgão responsável pela preservação da missão de Trinidad, sendo ligada à Presidência da República. De acordo com Jazmin Amazona (2014), membro da direção de patrimônio da SENATUR, os governos municipais ainda não possuem participação nas atividades relacionadas às Missões Jesuíticas, mas está sendo solicitado a eles que atuem na manutenção dos sítios históricos. Como no Brasil, não há participação de órgãos estaduais. Na Argentina, segundo Ayala (2014), a Comisión Nacional de Museos, Monumentos y Lugares Históricos é a responsável legal pelos sítios históricos missioneiros desde 1940. Em 1991, delegou os trabalhos à Subsecretaría de Gestión Estratégica de la provincia de Misiones, órgão estadual. Contudo, a Subsecretaria deve solicitar autorização à Comissão para todas as intervenções que forem realizadas. A municipalidade não possui participação. Ou seja, além da insuficiência de comunicação entre os

\footnotetext{
${ }^{63}$ Site: http://portal.iphan.gov.br/

${ }^{64}$ Site: www.ibram.org.br
} 
órgãos em nível internacional, a falta de colaboração e de interação entre todos os níveis de preservação dentro de cada um dos países também é fator que agrava o estado atual do sistema.

\section{Ações de preservação do patrimônio material imóvel}

Entre as principais funções dos órgãos responsáveis estão os chamados três pilares da museologia: pesquisa, preservação e divulgação. Segundo Thomson (1995 [1978]), a conservação como atividade profissional iniciou-se em 1950, com a fundação do Instituto Internacional para a Conservação de Objetos de Museu. O marco mais importante nesta área foi o Segundo Congresso Internacional de Arquitetos em Veneza, no ano de 1964, quando foi promulgada a Carta de Veneza (CIAM, 1964), que indica procedimentos para a salvaguarda dos bens, tais como a documentação das modificações realizadas, o repúdio à falsificação histórica e a reversibilidade das intervenções. Como consequência deste evento, foi criado no ano seguinte o Conselho Internacional de Monumentos e Sítios (ICOMOS - do inglês International Council of Monuments and Sites), cuja função é "[...] lidar com questões arqueológicas, arquitetônicas e de planejamento das cidades, para inventariar monumentos e sítios e para monitorar a legislação relevante" (THOMSON, 1995 [1978], s.p., tradução nossa ${ }^{65}$ ).

A pesquisa envolve não somente a busca por fatos históricos, mas também levantamentos sobre o estado de conservação das edificações e os fatores de degradação que atuam sobre elas. Dentre estes, os já citados guerras, abandono, saques, vegetação, deterioração dos elementos

\footnotetext{
${ }^{65}$ Do original em inglês: "[...] to deal with archeological, architectural and town planning questions, to schedule monuments and sites and to monitor relevant legislation" (THOMSON, 1995 [1978], s.p.).
} 
estruturais, intervenções inadequadas, esforços mecânicos e poluição do ar (CHAROLA; MAGADÁN; LANCELLOTTI, 2004); e umidade, luz, vapores ácidos, fumaça, poluição oxidante dos automóveis (THOMSON, 1995 [1978]). Tais condições podem ser controladas em espaços fechados, mas não em ambientes abertos, como é o caso das ruínas missioneiras nos sítios históricos pesquisados.

A ação do tempo e das intempéries são fatores de degradação decisivos a serem combatidos e controlados através de atividades realizadas pelos órgãos de preservação do patrimônio nos âmbitos de conservação, restauração e manutenção. Estes são processos distintos em seus objetivos. A conservação envolve "[...] o controle do ambiente para minimizar a decadência dos artefatos e materiais; e [...] seu tratamento para deter a decadência e estabilizá-los quando possível contra uma deterioração maior. [...]" (THONSOM, 1995 [1978], s.p., tradução nossa ${ }^{66}$ ). Quando este processo é insuficiente para reestabelecer a saúde da edificação, a restauração é utilizada como método de intervenção para sanar os problemas existentes, tendo caráter excepcional. E, após o reestabelecimento da edificação, seja pela conservação ou pela restauração, é necessária a manutenção deste estado através de procedimentos mais sutis, mas constantes, para evitar que o monumento volte a se degradar.

As igrejas concentraram a maioria das atividades de restauração e conservação realizadas nos três sítios históricos analisados, talvez por sua importância como símbolo maior da influência dos jesuítas nas Reduções e por suas grandes dimensões. O estado em que estas estruturas foram

\footnotetext{
${ }^{66}$ Do original em inglês: "[...] the control of the environment to minimize the decay of artefacts and materials; and [...] their treatment to arrest decay and to stabilize them where possible against further deterioration. [...]" (THOMSON, 1995 [1978], s.p.)
} 

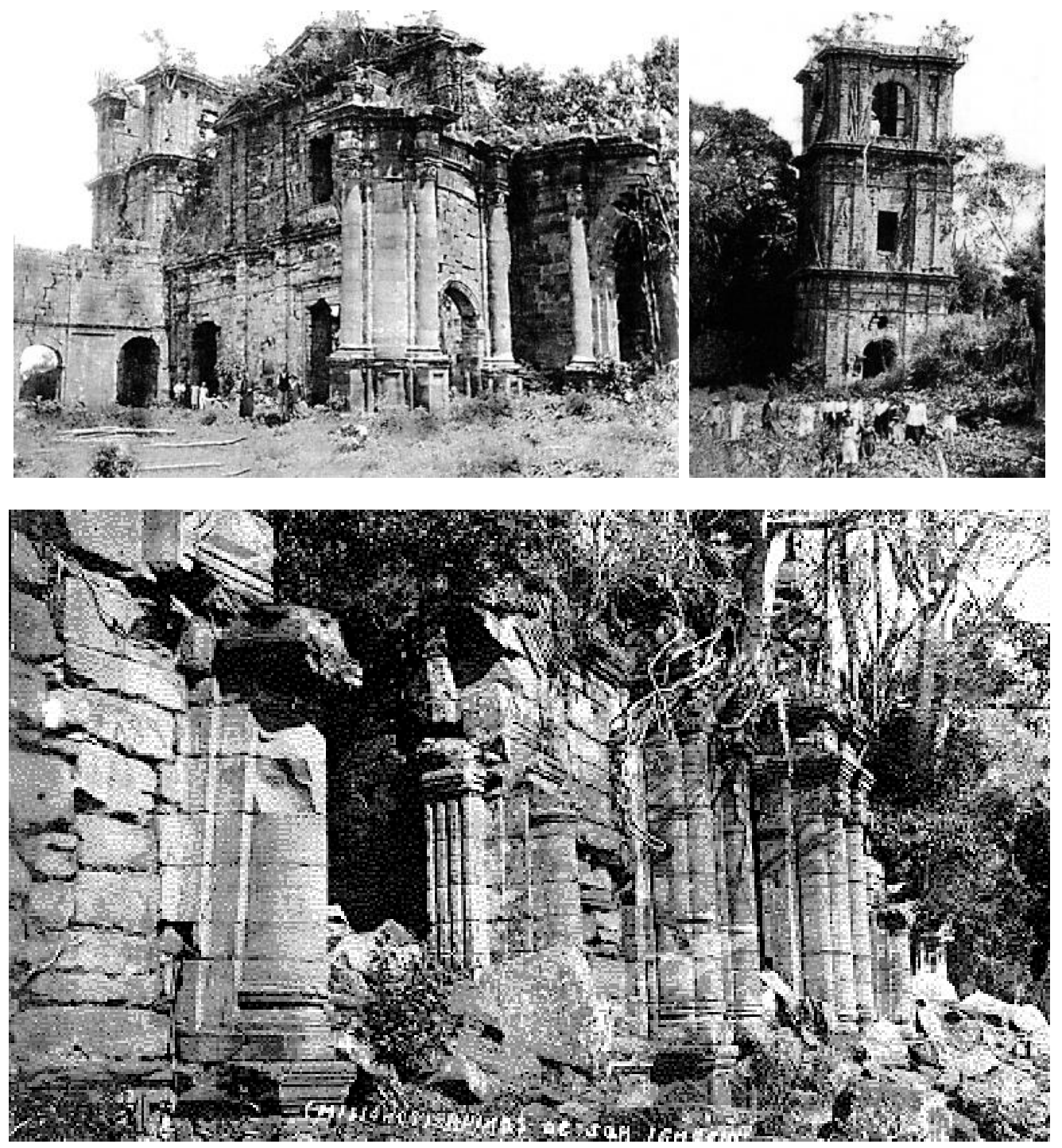

Figura 32. Estado de conservação das igrejas de São Miguel - Brasil e San Ignácio Miní - Argentina antes dos trabalhos de restauro. Fonte: SIMON, 2010, p. 48 e 50; POZZOBON, 2004, p. 33. 
encontradas era muito precário, como pode ser visto na Figura 32, na página ao lado.

No Brasil, em São Miguel, os trabalhos de conservação se iniciaram em 1925, através da Diretoria de Terras da Secretaria do Estado e Obras Públicas, do Estado do Rio Grande do Sul (ESCRITÓRIO, 2006, p. 1; JARAMILLO, 2004, p. 4). De acordo com Leal ${ }^{67}$ (1984, p. 80), neste período houve a erradicação da vegetação, reparos gerais, reconstrução e escoramento do pórtico, dentre outras. Segundo ele, as obras foram divididas em três frentes, de acordo com a área em que foram realizadas: na fachada principal, no interior da igreja e na torre. Segundo relatório de atividades do escritório técnico de São Miguel (ESCRITÓRIO, 2006, p. 1), em 1938, ano seguinte à criação do Serviço do Patrimônio Histórico e Artístico Nacional - SPHAN (atual IPHAN), as Ruínas de São Miguel Arcanjo foram reconhecidas como Patrimônio Nacional.

Nos anos de 1967 a 1969, o arqueólogo José Joaquim J. Proenza Brochado realizou sondagens estratigráficas nos sítios históricos missioneiros brasileiros e, no mesmo período, iniciaram-se as publicações científicas sobre o tema. Em 1978 foi realizado um plano diretor de preservação para o sítio histórico de São Miguel (CUSTÓDIO, 2003) e, de acordo com a arquiteta colombiana Matilde Jaramillo (2004, p. 3), “Diversas obras foram realizadas pelo órgão federal de preservação até que, a partir de 1981, iniciou-se um trabalho permanente de preservação do Sítio Arqueológico de São Miguel Arcanjo", que, segundo ela, abrange obras como a estabilização da torre, a consolidação de vergas pela substituição de madeira por concreto, a restauração da sacristia, a consolidação de estruturas fissuradas e do arco do pórtico, o controle do recalque da

\footnotetext{
${ }^{67} \mathrm{O}$ autor faz um relato minucioso de todas as ações realizadas ao longo da história da atuação dos órgãos responsáveis pela preservação do patrimônio nacional. Portanto, indica-se a leitura de seu texto para maiores informações sobre o assunto. $\mathrm{O}$ arquivo digital da Revista do Patrimônio pode ser encontrado no site do IPHAN.
} 
igreja, o reforço estrutural com estacas raiz, o tratamento dos blocos de fundação, o tratamento dos pisos e a limpeza do material pétreo talhado.

Na década de 1990, iniciaram-se os trabalhos de turismo cultural, educação patrimonial e foi restaurada uma das antigas fontes de água que abasteciam a missão. Esta foi a década em que uma grande quantidade de ações foram realizadas para divulgação do conhecimento sobre a história e o patrimônio missioneiros, como será visto no próximo capítulo, no item 3.2.

No Paraguai, a restauração de Trinidad ocorreu cerca de cinco décadas depois, entre 1968 e 1973 (TURISMO, s.d.), e as obras de conservação têm sido realizadas pelo órgão público responsável desde 1980, “[...] tendo como objetivo a criação de uma aparência mais apresentável e o reparo das devastações causadas pelo ataque atmosférico. O que foi acompanhado por um detalhado levantamento dos remanescentes e das evidências arqueológicas enterradas" (ICOMOS, 1992, p. 90, tradução nossa ${ }^{68}$ ).

Na Argentina, de acordo com Snihur (2007, p. 11), no início da fase pós-jesuítica, os governantes

[...] apenas perceberam as ruínas dos povoados, algumas das quais foram consideradas merecedoras de serem conservadas, e outras não, simplesmente porque já não possuíam muros em pé. Desta maneira, somente foram resgatados quatro povoados, enquanto que os sete restantes - além de mais algumas ruínas do período de 1638 a 1712, com suas capelas e outros vestígios - ficaram abandonadas à sua sorte.

\footnotetext{
${ }^{68}$ Do original em inglês: "[...] aimed at creating a more presentable appearance and repairing the ravages of atmospheric attack. This was accompanied by detailed survey of the standing remains and the buried archaeological evidence" (ICOMOS, 1993, p. 90).
} 
Segundo ele, foram selecionados quatro conjuntos, e San Ignácio Miní recebeu preferência dentre eles. Enquanto isso, os sítios históricos de Nuestra Señora de Loreto, Santa Ana e Santa María La Mayor foram apenas cercados, o que possibilitou a proteção de seus monumentos. De acordo com Biesek (2009, p. 3), “[...] Redescoberta em 1897, San Ignácio Miní [...] [ficou famosa] após o poeta Leopoldo Lugones fazer uma expedição à área em 1903 [...]”. Na década de 1910, a arqueóloga argentina Ruth Adela Poujade (2004) realizou estudo sobre as fundações do templo e do colégio de San Ignácio, bem como atividades dessa mesma natureza em outras estruturas das demais Reduções argentinas. Segundo ela, "Nos anos 40, o empreendimento mais espetacular foi a Reconstrução de San Ignácio Miní realizado pela Comissão Nacional de Museus, Monumentos e Sítios Históricos e pela Direção Nacional de Arquitetura, sob a liderança do Arq. Carlos Luis Onetto, que esteve acompanhado pelo Arq. Vicente Nadal Mora [...]" (POUJADE, 2004, p. 9, tradução nossa $\left.{ }^{69}\right)$. San Ignácio Miní incorpora "vestígios monumentais importantes: igreja, residência dos padres, escola, assim como aproximadamente trinta unidades de moradias. [...]" (ICOMOS, 1983, p. 5, tradução nossa ${ }^{70}$ ).

De acordo com Pozzobon (2004, p. 28), além do restauro realizado entre 1941 e 1948, foram realizadas algumas obras no sítio histórico de San Ignácio Miní: manutenção (1950-1990); limpeza periódica, incluindo as estruturas e a vegetação invasiva; organização e manutenção de um pequeno museu interno e de um centro de interpretação externo. Além disso, o sitio histórico é

\footnotetext{
${ }^{69}$ Do original em espanhol: “En los 40, el emprendimiento más espectacular fue la Reconstrucción de San Ignácio Miní encarada por la Comisión Nacional de Museos, Monumentos y Sitios Históricos y por la Dirección Nacional de Arquitectura, bajo la dirección del Arq Carlos Luis Onetto, quien estuvo acompañado por el Arq. Vicente Nadal Mora [...]" (POUJADE, 2004, p. 9).

${ }^{70}$ Do original em inglês: "[...] monumental vestiges: church, residence of the fathers, school, as well as approximately thirty living units. [...]" (ICOMOS, 1983, p. 5).
} 
aberto à visitação pública e conta com guias de turismo instruídos. Na igreja, foram realizadas escavações pontuais (1991), um escoramento (1999) e a consolidação estrutural.

Portanto, a conscientização da necessidade de preservação das Missões Jesuíticas histórica e culturalmente em termos nacionais e regionais ocorreu nos anos 1900, em cada país a seu tempo. A partir deste momento, os órgãos responsáveis empreenderam grandes esforços para sua preservação, desde ações administrativas - como o reconhecimento internacional através da inclusão na Lista do Patrimônio Mundial - até atividades de restauro sem as quais o estado de degradação dos sítios históricos seria muito mais severo, comprometendo ainda mais a apreciação e o entendimento desta experiência histórica intercultural tão peculiar.

Através de atividades museológicas, é possível reunir e apresentar a complexidade inerente a objetos que representam as Missões. Segundo a historiadora brasileira Letícia Bauer (2009, p. 9),

Ao mesmo tempo em que temos o comprometimento com o estudo constante dos vestígios materiais da experiência missional como suporte de informação singular, é necessária a busca constante de informações sobre o mundo que, hoje, falta ao redor do vestígio. [...] articuladores de relações entre vestígios materiais e informações do tempo em que tais fragmentos foram operados em seus usos originais.

Contudo, segundo Meira (2010, p. 1),

[...] há muito mais a ser pesquisado, pois a rede formada pelos antigos trinta povos ocupava um vasto território que hoje pertence a vários países e seus testemunhos precisam ser melhor conhecidos. [...] um desafio grande é desenvolver $\mathrm{o}$ afeto das populações que se radicaram mais recentemente na região (e que por isso não se identificam com o legado missioneiro), com o patrimônio cultural das missões, pois ele é importante para toda a humanidade.

De acordo com a historiadora francesa Françoise Choay (2001), esta ligação afetiva com o monumento é imprescindível, pois se, além de injuriado pelo tempo vivido, ainda for inutilizado, 
esquecido e não se cultivar um apego por ele, é provável que ele vá ruir. Portanto, “a conservação e o restauro concretos, efetivos, exigem a conjugação de uma forte motivação de ordem afetiva e de um conhecimento" (CHOAY, 2001, p. 75). Neste sentido, os "Museus são espaços de prazer, de descoberta, de gosto pelo saber. Querem provocar o visitante, instigar a pesquisa" (YUNES, 2011, p. 1), podendo atuar como intermediadores no processo de reconstrução da afetividade da população para com seu patrimônio.

\section{Ações de preservação do patrimônio material móvel}

Segundo Petry (2013, s.p.), a vinculação do IPHAN ao Ministério da Cultura faz com que sua atuação seja voltada à restauração e manutenção dos monumentos históricos e à divulgação da cultura e da história. Em relação ao patrimônio móvel, são realizadas atividades de restauro das esculturas missioneiras presentes no Museu das Missões, projetado pelo Arquiteto e Urbanista brasileiro Lucio Costa em 1940, que reúne “[...] a maior coleção pública de imagens sacras e fragmentos missioneiros do Mercosul, expondo uma rica coleção da arte barroca elaborada pelos índios guarani nas reduções jesuíticas [...]" (IBRAM, s.d., p. 1), muitas delas em madeira policromada. Cujo objetivo é o de

[...] Tratava-se, pois, no Museu das Missões, de lançar mão dos elementos remanescentes, de se apropriar 'das peças que, sobrevivendo à catástrofe (...) deram à praia', para evocar poeticamente a memória da gente que ali habitou, graças à impressão que tais elementos pudessem suscitar à imaginação do visitante (COSTA apud CARRILHO, 2006, p. 2). 

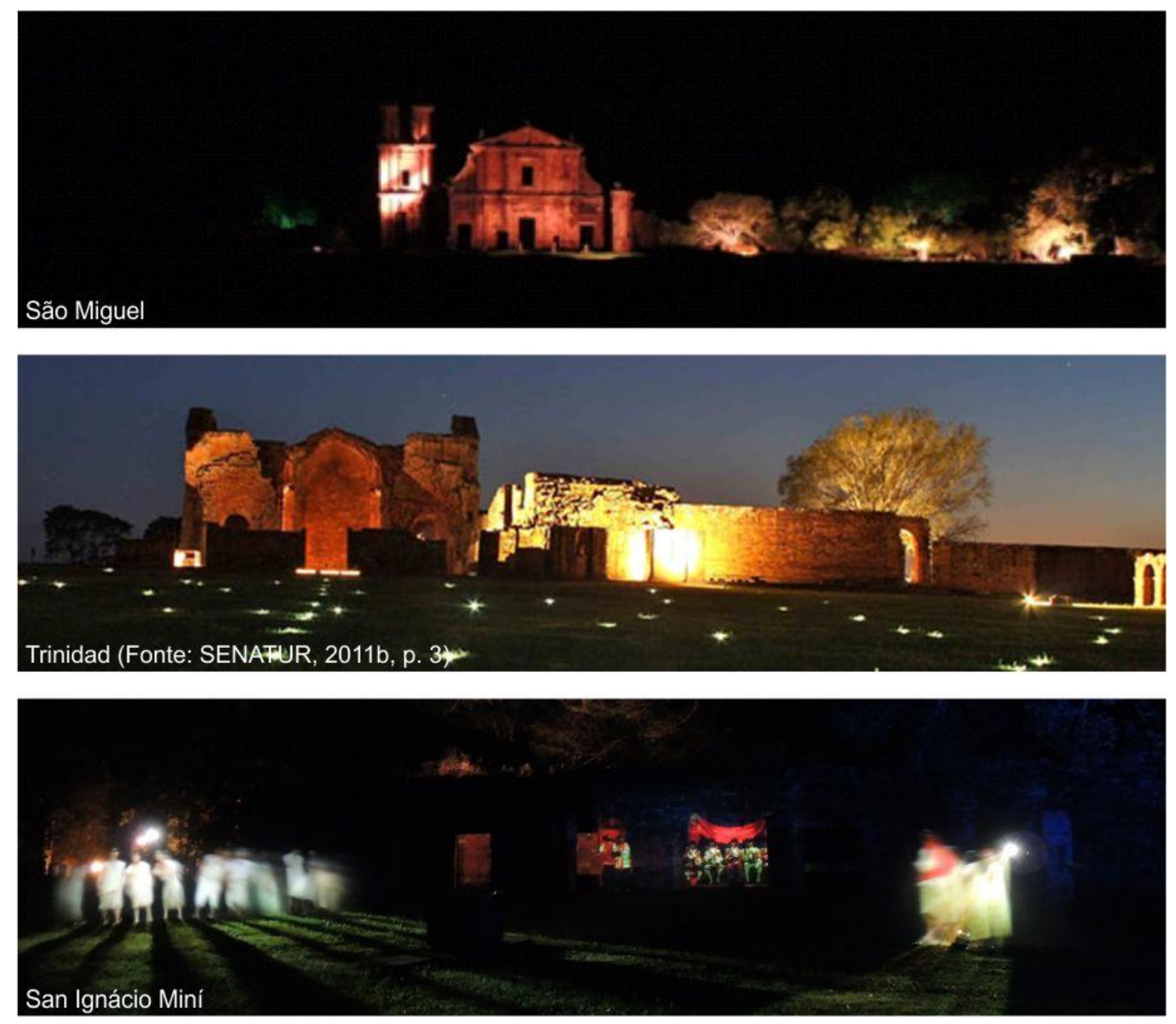

Figura 33. Espetáculos noturnos e os trajetos realizados em Trinidad - Paraguai e San Ignácio Miní - Argentina. Fonte: Créditos nas fotos. 
Na década de 1980, iniciaram-se as atividades de preservação permanente do sítio histórico de São Miguel (CUSTÓDIO, 2004a), foi realizada a recuperação do Museu das Missões e se iniciou a restauração das esculturas missioneiras. Ações relacionadas ao registro do patrimônio imaterial representado pela cultura dos mbya guarani ocorreram mais recentemente (MEIRA, 2010, p. 1), sendo um exemplo o livro Tava Miri São Miguel Arcanjo, sagrada aldeia de pedra: os MbyaGuarani nas Missões, um registro da cultura desta tribo, incluindo artesanato, danças e canções.

Os órgãos responsáveis pelas Missões também organizam espetáculos noturnos (Figura 33, na página ao lado) que auxiliam na divulgação da história missioneira. Em São Miguel é chamado Som e $\mathrm{Luz}^{71}$ e retrata parte da história missioneira nacional através de narrativa e luzes projetadas sobre a fachada da igreja. Em Trinidad, chama-se Luces y Sonidos e utiliza iluminação, imagens e música do jesuíta Domenico Zípoli ${ }^{72}$ como pano de fundo para uma visita guiada em meio às ruínas. Em San Ignácio Miní, o espetáculo Imagen y Sonido utiliza projeções sobre muros e brumas artificiais de água.

Ao contrário de São Miguel, em que o visitante escuta uma gravação, sentado em uma arquibancada, em Trinidad e San Ignácio Miní o visitante é guiado em meio às edificações. Tais espetáculos proporcionam ao visitante uma experiência mais sensível e imersiva no cenário histórico missioneiro do que a simples visitação guiada diurna ou a apreciação das obras expostas nos museus nos três sítios históricos. Cada um dos espetáculos proporciona sensações e

\footnotetext{
${ }^{71}$ Segundo Custódio (2014), o espetáculo de São Miguel foi idealizado e executado em 1876 como uma atividade temporária, com previsão de duração de um mês, mas permanece até os dias atuais.

${ }^{72}$ Na década de 1710, Domenico Zípoli acompanhou o arquiteto Jean Batista Primoli, construtor das igrejas de São Miguel, no Brasil e Trinidad, no Paraguai, dentre outras obras (GRANCE, 2009, p. 2). Em sua época, Zipoli foi o músico mais conhecido na América do sul.
} 


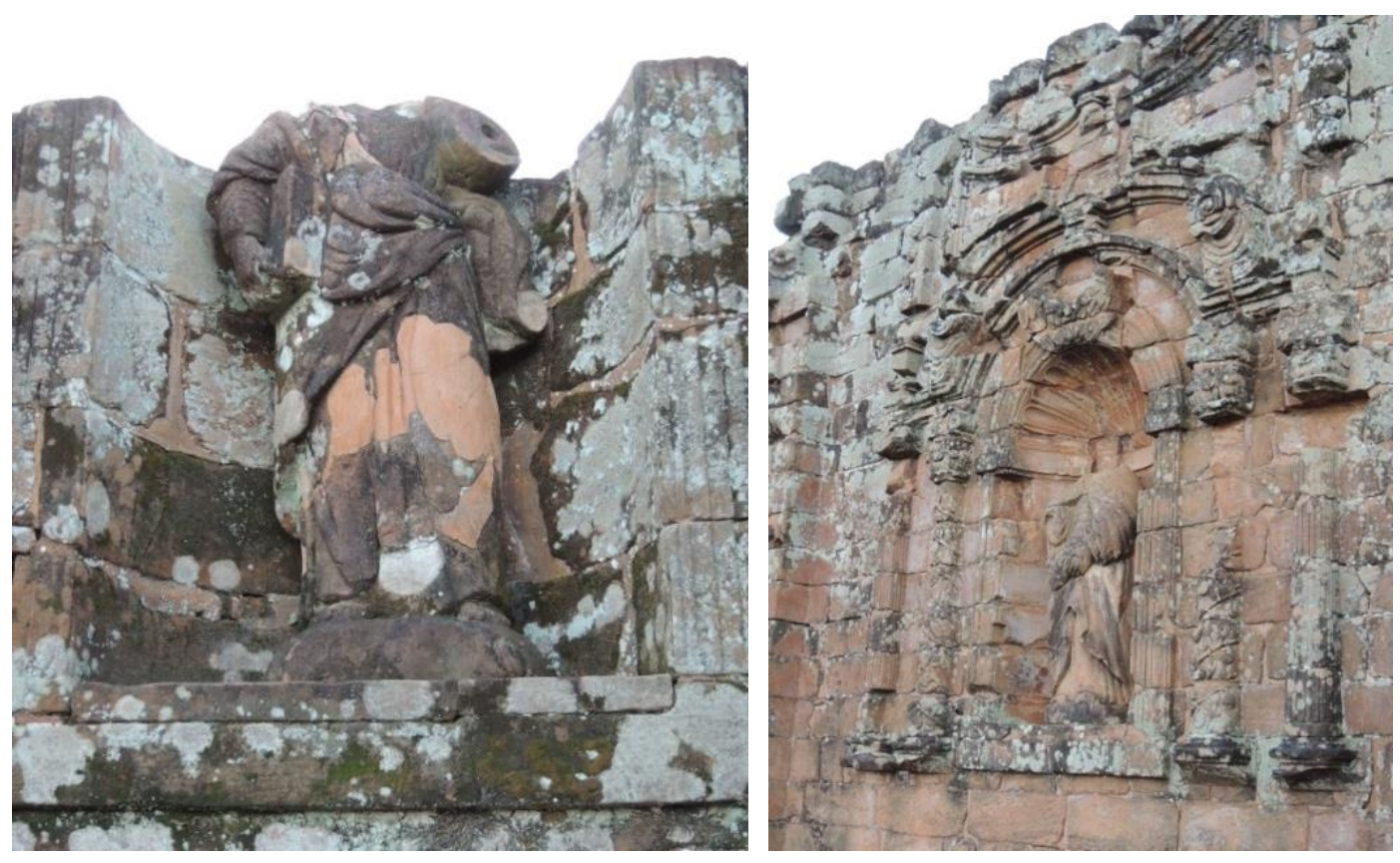

Figura 34. Obras de arte de pedra mantidas na igreja de Trinidad, sujeitas à ação de fatores climáticos.

Fonte: Fotos da autora. 
informações distintas, inclusive pelas próprias tecnologias utilizadas de acordo com a época em que foram idealizados e implementados, tendo um caráter de complementariedade.

Estes espetáculos auxiliam a divulgação da história e da cultura que permeiam os sítios históricos e estão impregnadas na materialidade das ruínas das edificações e também nas obras de arte, que foram resgatadas das igrejas e hoje são mantidas nos museus no Brasil, no Paraguai (SUSTERSIC, 1997, p. 157) e na Argentina. Tal ação de retirada de elementos das edificações é amparada pela Carta de Veneza pela impossibilidade de assegurar sua conservação se mantidos junto às ruínas, como em Trinidad (Figura 34, na página ao lado), onde sofrem os efeitos de fatores climáticos e ambientais da mesma forma como as edificações, pois ficam desprotegidas pela falta de cobertura nestes locais. Aquelas obras que são mantidas junto às edificações devem ser alvo de uma atenção redobrada para controlar seu nível de deterioração ou, por se tratarem de bens patrimoniais móveis, podem ser movidas para o interior de edificações que possam abrigá-las de maneira apropriada.

Os museus oferecem condições apropriadas para a preservação destas obras, pois diversos fatores são controlados para que as peças não mais se deteriorem, dentre eles temperatura, umidade, cigarro, sol, chuva, chuva ácida (THOMSON, 1995 [1978]). A poluição e as intempéries são fatores de deterioração já mencionados na Carta de Atenas (1931) e que podem ser combatidos e controlados através de ações de conservação, restauração e manutenção realizadas pelos órgãos de preservação do patrimônio, conforme especificado nas diversas cartas patrimoniais.

Contudo, o museu pode ser caracterizado como "Lugar de memória. Instituição que abriga suportes de memórias" (CURY, 2012, p. 23). E não somente as abriga, mas também realiza os 
esforços possíveis para sua restauração e preservação, com a finalidade de veicular a cultura e a história, educar e reforçar uma identidade local. Isso porque sua história o configura como "o lugar onde se recolhiam os conhecimentos da humanidade. [...] Um espaço onde se reúnem objetos que, exibidos sistematizadamente, transmitem uma mensagem" (KERRIOU, 1992, p. 8990). Como enfatiza o cientista da informação alemão Werner Schweibenz (1998), ao mesmo tempo lida com objetos físicos e dissemina conhecimento.

O museu apenas como abrigo soberano e imutável de obras de arte materiais está ultrapassado e não instiga a população a visitá-lo. Atualmente, este espaço passa por transformações profundas em seus conceitos norteadores, que o estão transformando em um local dedicado ao encontro da população com sua cultura.

[...] Engajando-se com a afirmação de Marshall McLuhan de que a sociedade da informação e as novas mídias têm o potencial de facilitar a interação e a acessibilidade sociais, MacDonald (1992) reformula os museus primeiramente como lugares para a disseminação de informação muito mais do que uma central repositória para objetos. [...] (CAMERON, 2007, p. 51, tradução nossa ${ }^{73}$ ).

Portanto, o museu passa a ser um espaço que abriga não somente objetos físicos, mas incorpora cada vez mais as tecnologias disponíveis para representá-la, inclusive instâncias virtuais que ampliam sua atuação. A museóloga australiana Andrea Witcomb (2007) afirma que a introdução de tecnologias multimídia nos museus é uma oportunidade para que eles se reinventem e garantam sua sobrevivência. A autora afirma que

Desde a introdução da multimídia digital no mundo dos museus através de coisas como websites, interações via computador, hologramas, e filmes e sons

\footnotetext{
${ }^{73}$ Do original em inglês: “[...] Engaging Marshall McLuhana argument that the information society and new media has the potential to facilitate social interaction and accessibility, MacDonald (1992) reframes museums primarily as places for the dissemination of information rather than a central repository for objects. [...]" (WITCOMB, 2007, p. 51).
} 
digitalizados, profissionais e críticos têm lamentado ou celebrado estas tecnologias. Para seus proponentes, estas tecnologias têm se tornado emblemáticas da emergência de um novo museu - um museu que está focado em fornecer tanto acesso intelectual como físico, democratizando a interpretação de sua coleção através do uso de um modo de comunicação associado à cultura popular contemporânea. [...] (WITCOMB, 2007, p. 37, tradução nossa ${ }^{74}$ )

Estas tecnologias possibilitaram olhares diferenciados sobre as funções do museu, direcionando-o mais ao visitante. Segundo Mazzola (2013), o museu tem a potencialidade de desenvolver em seus visitantes habilidades de observação, análise e comunicação, em um processo que a museóloga brasileira Marília Cury (2012, p. 30) afirma ser marcado por três sujeitos: o autor representado por sua obra, os profissionais que guiam a visita e expõem dados, e o público visitante que busca apreender e aprender. Nas palavras do museólogo brasileiro Mário Chagas et al (2010 , p. 49) "O museu pode ser compreendido como instituição cultural e tecnologia social capaz de ressignificar a herança cultural e colocar em evidência ou mesmo em confronto narrativas, discursos e interpretações distintas".

Neste sentido, as ações nacionais envolvem não somente a restauração e conservação das obras de arte, mas também a divulgação da cultura e da história nelas impregnadas e uma ressignificação do próprio papel do museu não somente como um mero abrigo de obras de arte, mas também como agente fundamental para o pleno exercício da cidadania. Em direção a

\footnotetext{
${ }^{74}$ Do original em inglês: "Since the introduction of digital multimedia into the world of museums through such things as Web sites, computer interactives, holograms, and digitized film and sound, museums practitioners and critics have either lamented or celebrated these developments. For its proponents, these developments have become emblematic of the emergence of a new museum - one which is focused on providing both intellectual and physical access, democratizing the interpretation of its holdings by using a mode of communication associated with contemporary popular culture. [...]" (WITCOMB, 2007, p. 37).
} 
constituir o que Cury (2012, p. 24) chama de "Lugar de construção de valores a partir do patrimônio cultural", valores vivenciados e compreendidos através da materialidade que constituem os objetos de outra época. O que demonstra a importância não somente do patrimônio material e imaterial, mas também destes espaços de conhecimento e de reflexão.

\section{Ações de preservação do patrimônio imaterial}

A produção de conhecimento acerca do patrimônio imaterial das Missões Jesuíticas, sua história e sua cultura, é realizada basicamente em universidades dos países envolvidos. No Brasil, a Universidade do Vale do Rio dos Sinos (Unisinos) se destaca no estudo sobre ao tema. Localizada em São Leopoldo-RS, é uma instituição privada jesuíta de ensino superior, que se interessa particularmente pela pesquisa relacionada a sua própria história. Sua história de pesquisa sobre o tema é longa e atualmente sedia o grupo de pesquisa Jesuítas nas Américas, formado em 1999 e liderado pelos professores Dra. Maria Cristina Bohn Martins e Dr. Fernando Torres Londoño. A instituição também foi responsável pela reconstrução virtual do sítio de São Miguel Arcanjo, que será analisada no próximo capítulo, no item 3.2. Além disso, várias outras instituições de ensino brasileiras estudam o tema, em diversas regiões do país, tais como a Universidade de São Paulo (USP) e a Universidade Federal de Santa Catarina (UFSC), com grupos de pesquisas em áreas complementares como arquitetura, sociologia e direito. No Paraguai, destaca-se a Facultad de Arquitectura, Diseño y Arte (FADA), da Universidad Nacional de Asunción. Em especial o Departamento de Historia y Património, dirigido pelo Prof. Dr. Carlos Cataldi, onde são realizados trabalhos de graduação e mestrado sobre o tema. Na Argentina, é bastante relevante o trabalho do Centro de Documentación de Arquitectura Latinoamericana (CEDODAL), 
localizado em Buenos Aires e dirigido pelo Prof. Dr. Arq. Ramón Gutiérrez. Segundo o site da instituição, "O CEDODAL tem como objetivo consolidar uma nova consciência em matéria de preservação e difusão do patrimônio arquitetônico e urbano, com investigações surgidas a partir da documentação que resguarda e graças ao aporte de outros acervos públicos e privados" (www.cedodal.com, tradução nossa ${ }^{75}$ ).

Além das instituições, um grande número de pesquisadores dedica-se ao tema, não somente nos países em que se inserem as Reduções Jesuíticas. Sem a pretensão de esgotar os nomes dos pesquisadores importantes da área, a seguir são destacados apenas quatro de cada país, sendo impossível organizá-los em ordem de importância, pois cada um contribui de forma inestimável para a área. No Brasil: o Prof. Dr. Luiz Bolcato Custódio, arquiteto que tem se dedicado ao estudo e preservação da arquitetura missioneira; o Prof. Dr. Arno Alvarez Kern, historiador que tem se dedicado a estudar a arqueologia e a história dos sítios missioneiros; o jesuíta Prof. Dr. Pedro Ignácio Schmitz SJ, filósofo, geógrafo, teólogo e historiador, que desde 1969 pesquisa questões antropológicas, inclusive sobre as Missões Jesuíticas; e o Prof. Dr. Jean Baptista, historiador que analisa a documentação jesuítica e obras de viajantes do século XIX.

No Paraguai: o Prof. Dr. Bartolomeu Melià, jesuíta que convive com os guarani há 40 anos; o teólogo Dr. José Maria Blanch, jesuíta que estuda a história jesuítica; Blanca Victoria Amaral Lovera e Margarita Durán Estragó que estudam a conservação e restauração das igrejas missioneiras; e o musicólogo Clement Mc Naspy (in memorian), também jesuíta que auxiliou o resgate do repertório musical missioneiro.

\footnotetext{
${ }^{75}$ Do original em espanhol: "El CEDODAL tiene como objetivo el consolidar una nueva conciencia en materia de preservación y difusión del patrimonio arquitectónico y urbano, con investigaciones surgidas a partir de la documentación que resguarda y gracias al aporte de otros acervos públicos y privados" (www.cedodal.com).
} 
Na Argentina: a Profa. Dra. Ruth Adela Poujade, arqueóloga que realizou o levantamento dos sítios missioneiros; o Prof. Dr. Ramón Gutiérrez, arquiteto, diretor do Centro de Documentação de Arquitetura Latino-americana (CEDODAL), que estuda a arquitetura latino-americana; o Prof. Dr. Ernesto Maeder, historiador, Consultor da UNESCO para temas de Patrimônio na América Latina, que também trabalha na área da arquitetura ibero-americana; e o Prof. Dr. Esteban Angel Snihur, também historiador, trabalha questões ligadas à gestão do desenvolvimento turístico.

E também de outros países, como Francisco B. Medina SJ e Rafael Carbonell De Masy SJ da Pontificia Universidad Gregoriana, na Itália; Elisa Villalpando Canchola e Rodrigo F. Rentería do Instituto Nacional de Antropología e Historia, Sonora, do México ; María José Diez Gálvez da Agencia Española de Cooperación Internacional - Plan de Rehabilitación Integral Misiones de Chiquitos; Eckart Kühne da Universidad Técnica Federal ETH Zürich, da Suíça. Como afirma Petry (2013), é muito difícil mensurar a abrangência dos estudos relacionados às Missões Jesuíticas, pois muitos países estão envolvidos com o tema e pouco ainda se comunicam entre si. Segundo ela, o contato com as instituições responsáveis ocorre apenas quando são realizados trabalhos mais técnicos, mas muitas pesquisas são realizadas sem o conhecimento dos órgãos preservacionistas.

Além do conhecimento produzido no ambiente acadêmico, interessa a esta pesquisa discutir a relação do visitante com o monumento, a percepção da imaterialidade que emana dos bens materiais. Segundo o historiador norte-americano Neil Silberman $\left(2005\right.$, p. 9, tradução nossa $\left.{ }^{76}\right)$,

\footnotetext{
${ }^{76}$ Do original em inglês: "[...] We can never re-create the past as it actually was, with its sense of uncompleted presentness and uncertain expectation [...]. We can accurately chart settlement patterns on the landscape, and perhaps even approximate the outward physical appearance of ancient communities. But we can only guess at the human dimension of past civilisations by piecing their surviving fragments together with the glue of our own ideas of logic
} 
[...] Nunca podemos re-criar o passado como ele realmente era, com seu senso de presente incompleto e expectativa incerta [...]. Podemos traçar com precisão os padrões de assentamento na paisagem, e talvez até mesmo aproximar a aparência física externa das comunidades antigas. Mas podemos somente adivinhar a dimensão humana das civilizações passadas ao reunir seus fragmentos remanescentes com a cola de nossas ideias de lógica e causa e efeito. E essa cola, ao contrário dos fragmentos antigos que ela mantém unidos, vem das esperanças, medos, sonhos e ideologias da era em que nós vivemos.

A percepção do passado é realizada através do olhar do observador, através do plano de fundo de suas crenças e de sua história. Segundo Morin (2005 [1970], p. 395), "Não percebemos nem conhecemos as 'coisas tais como são': percebemos signos, e a partir desses signos fazemos inferências e edificamos nossos modelos mentais do mundo; podemos vê-lo e ouvi-lo; falamos acerca de coisas 'reais'”. Este aspecto intangível (memória ou conhecimento) é acessado através da observação da materialidade de um bem patrimonial, que, de acordo com o sociólogo alemão Karl Müller (2007, p. 417-4 22), é fundamentalmente dependente de três fatores: contextualização, desconstrução e enriquecimento, e auto-referenciamento. Segundo o autor, a contextualização localiza os acontecimentos e objetos em um tempo e espaço específicos. E somente através do uso de um viés embasado nestas condições é possível realizar medições, hipóteses e teorias científicas. A desconstrução e o enriquecimento dos objetos analisa a obra em todos os seus elementos e características e amplia seu significado através de maiores informações. Dessa forma, realiza a união entre os âmbitos material e imaterial do patrimônio, justificando a preservação de determinados objetos pela história a que estão atrelados e pelos valores que emanam. E o auto-referenciamento, que trata do próprio processo de produção do

and cause-and-effect. And that glue, unlike the ancient shards that it holds together, comes from the hopes, fears, dreams and ideologies of the era in which we live" (SILBERMAN, 2005, p. 9). 


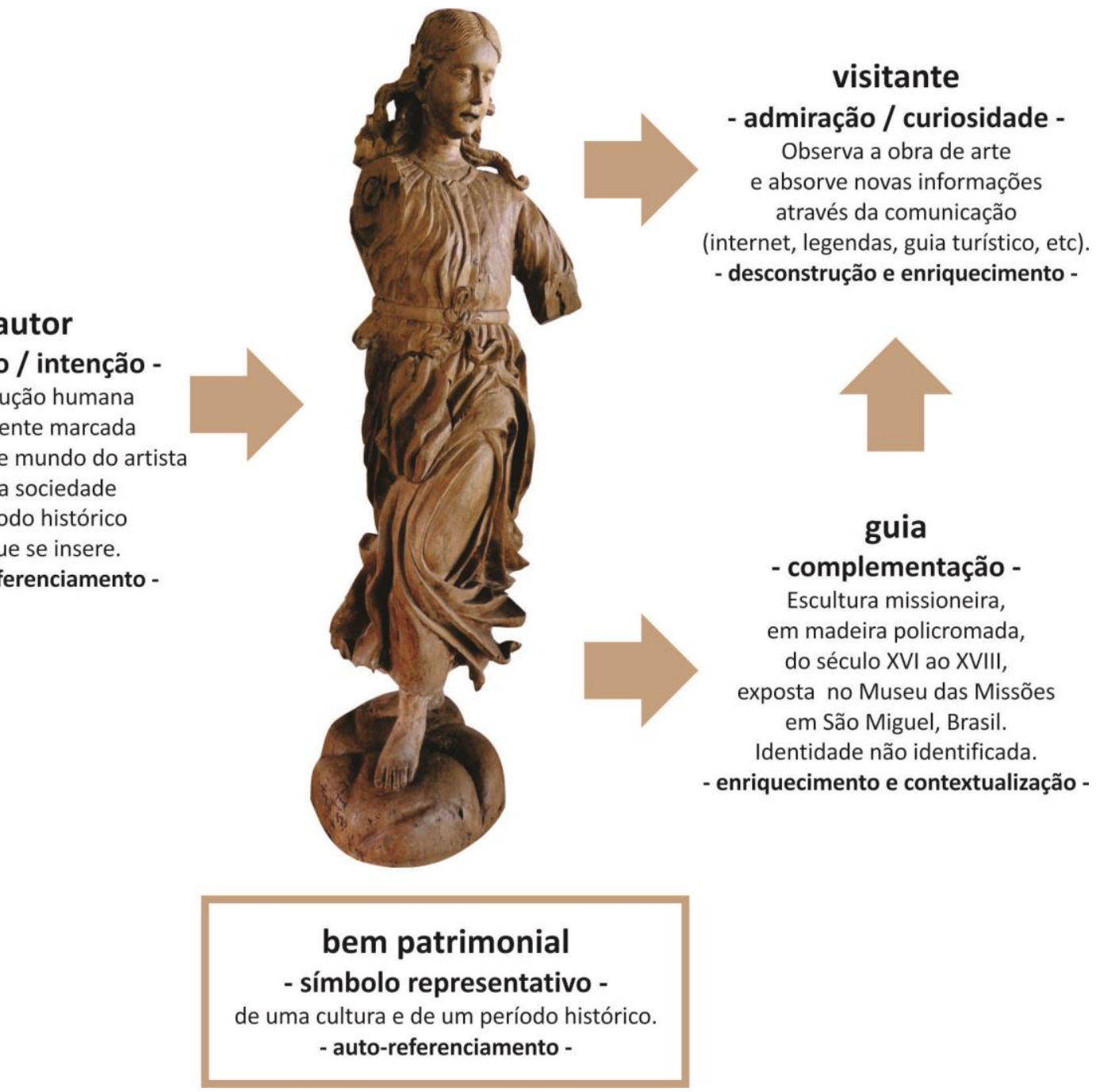

Figura 35. Os três sujeitos envolvidos na observação museológica (CURY, 2012)

analisados sob o viés da dependência do observador (MÜLLER, 2007).

Fonte: Elaborada pela autora. 
objeto que se insere dentro de um determinado contexto espaço-temporal.

Os objetos e as ruínas das Reduções Jesuíticas conservam e emanam o que a historiadora brasileira Sandra Pesavento (2009, p. 14) chama de "sensações, emoções e sentimento [, que] são postos em ação com os dados que estão armazenados em nosso arquivo de memória, repleto de figuras e ideias que permitem transformar a imagem visual em imagem mental". Esta imagem mental é formulada individualmente através de observação e reflexão. Todo significado só existe na concepção única de cada pessoa, através de toda história e cultura que a influenciam e que somente possuem valor para ela, seguindo os três fatores de dependência de Müller. Este sistema significativo individual, segundo Morin (2005, p. 401), só pode ser discutido se contextualizado de acordo com seu criador e com o momento temporal em que foi produzido, pois o indivíduo em si modifica seus valores ao longo da vida. Neste contexto, analisam-se os três sujeitos de uma observação museológica citados por Assim Cury (2012, p. 30) -autor, profissional e visitante-, que no sistema complexo da observação permitem entender que a observação depende não somente dos valores daquele que observa e desconstrói o bem patrimonial e do indivíduo que o enriquece e contextualiza através de informações, mas também dos valores inerentes ao objeto (por ser produzido por mão humana e expressar sua individualidade - auto-referenciamento) (Figura 35, na página ao lado).

Essa individualidade do significado amplia a importância da preservação do patrimônio, já que somente determinado grupo (criador e apropriador dessa herança) possui o conhecimento para compreendê-lo plenamente e, portanto, entende seu valor como suporte para cultura. Por ser este suporte, o patrimônio é peça-chave para o entendimento deste grupo, especialmente quando o grupo está extinto, como é o caso das Missões Jesuíticas, entendidas em toda a complexidade da relação entre jesuítas e guarani no período histórico determinado em que 

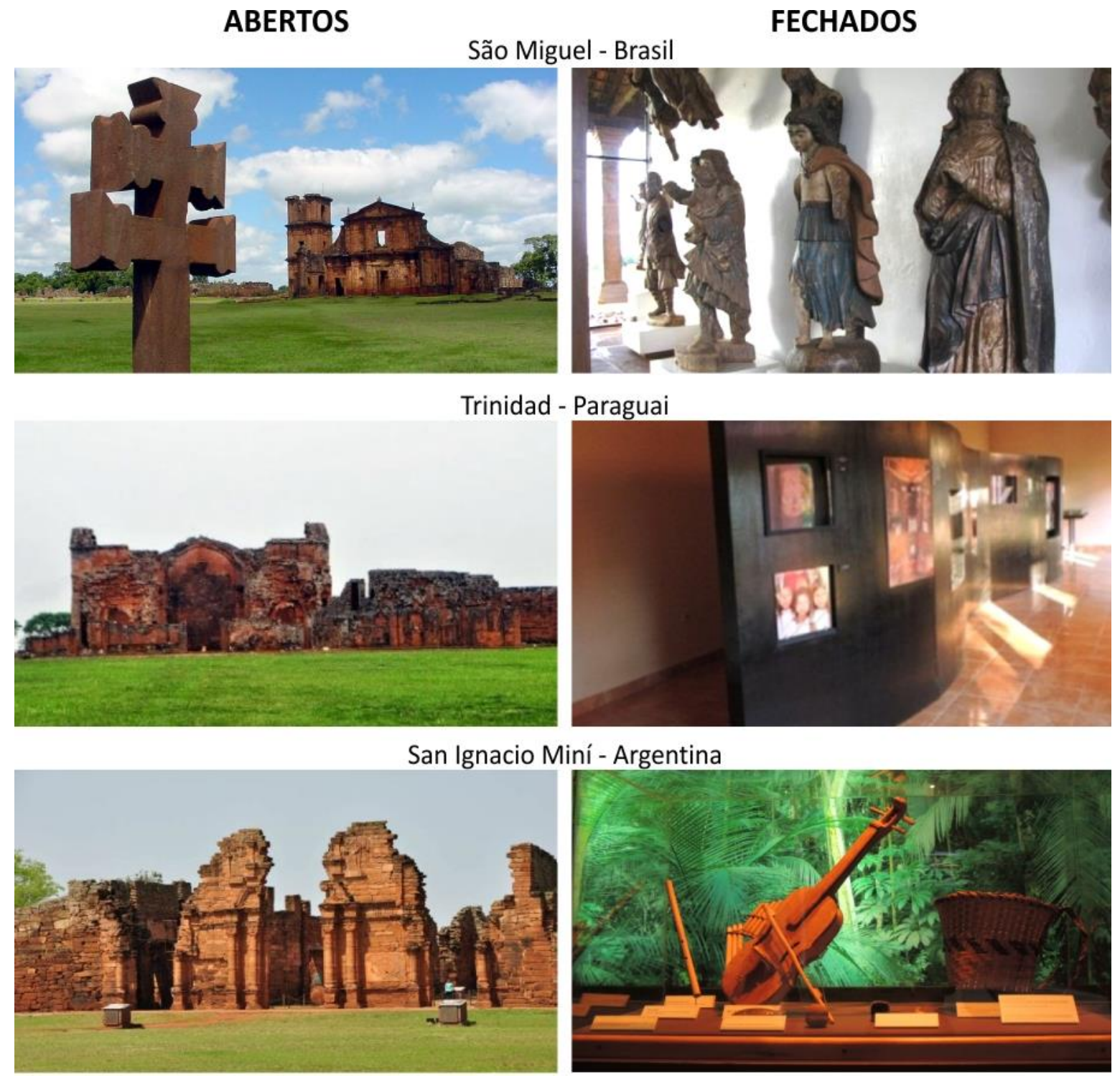

Figura 36. Espaços museológicos das Missões visitadas.

Fonte: Elaborada pela autora com fotos da autora. 
ocorreu, sob as relações sociais, econômicas e políticas vigentes. Neste caso, a singularidade dos objetos faz premente sua preservação, pois o conhecimento para produzi-los se perdeu.

\subsection{Complexidade da preservação do patrimônio missioneiro}

As atividades relacionadas às Missões Jesuíticas são realizadas em âmbito nacional e deve-se entender a importância de um olhar necessário e urgente para a preservação deste patrimônio de forma colaborativa entre os três países em que as Missões se localizam e com instituições internacionais, como a UNESCO. As nações possuem consciência da importância do conjunto, pois incentivam as rotas turísticas nacionais, mas atualmente poucas interações são realizadas entre os países ${ }^{77}$. Contudo, é de consciência dos órgãos responsáveis a necessidade de uma preservação integrada, faltando apenas incentivos e meios para sua concretização, esbarrando-se em entraves administrativos, políticos e econômicos.

Os esforços nacionais já realizados para reunir, restaurar e preservar o patrimônio missioneiro resultaram basicamente em dois tipos de espaços museológicos físicos (Figura 36, na página ao lado). O primeiro, ao ar livre, é constituído pelos remanescentes imóveis, envolvendo basicamente as ruínas das edificações presentes nos sítios históricos. O segundo tipo, fechado, envolve os museus propriamente ditos, que abrigam o patrimônio móvel, constituído em sua maioria por estátuas de madeira policromada. Já o patrimônio imaterial é produzido nas

\footnotetext{
${ }^{77}$ Na década de 1990, eram mais numerosas as interações internacionais, inclusive por conta das reuniões da Comissão Técnica do Patrimônio do Mercosul, como será apresentado mais adiante.
} 
universidades e geralmente não circula de maneira adequada dentro do sistema de preservação do patrimônio missioneiro, de modo que os demais agentes envolvidos normalmente não estão cientes do conhecimento produzido pelos pesquisadores.

Nos espaços museológicos abertos destaca-se a abordagem realizada em San Ignácio Miní Argentina, onde foram instalados totens de apoio com diversas informações sobre a história e a cultura das Missões Jesuíticas. Enquanto em São Miguel - Brasil é necessário agendar um guia de turismo para acompanhar uma visita e ele apenas está disponível para excursões; nos outros dois locais, os guias ficam disponíveis in loco para o passeio com os visitantes.

Tanto em espaços fechados, quanto nos abertos, prevalece um caráter mais expositivo dos bens e das informações. Atualmente, as informações são disponibilizadas nos sítios históricos através de visitas guiadas às ruínas e dos espetáculos noturnos ${ }^{78}$. Cada qual com suas especificidades, em busca de complementar e ampliar a noção histórica do visitante e seu entendimento sobre o valor desta cultura para a região e para o mundo. Mas esta divulgação da cultura e da história relacionadas a este período histórico com a finalidade de contextualizar e complementar a materialidade dos vestígios encontrados pode ser ainda mais efetiva através da adoção de outras metodologias. As experiências atuais de observação podem ser complementadas com atividades que instiguem uma reflexão mais aprofundada sobre o passado e sobre si mesmo; sobre as continuidades históricas e a possível necessidade de mudanças sociais na atualidade. Dessa forma, este testemunho histórico presente na materialidade das obras salvaguardadas poderia se converter em uma experiência muito mais instigadora e transformadora.

\footnotetext{
${ }^{78}$ Segundo Custódio (2014), na década de 1990, eram realizados diversos eventos com a comunidade no sítio histórico de São Miguel, no Brasil.
} 
Em parte esta questão é provocada pela abordagem administrativa atual dos sítios históricos, que é predominantemente nacional e voltada para o turista. Neste contexto, entende-se nesta pesquisa que, para que o patrimônio se mantenha vivo e atual, os espaços museológicos missioneiros poderiam ir além da definição observacionista antiquada e limitadora de museu como simples local de exposição dos objetos, levando o visitante a um questionamento sobre as relações existentes entre os diversos elementos que compuseram essa miscigenação cultural. A contextualização histórica, política e social pode gerar uma reflexão sobre este período histórico, levando o visitante a um entendimento de suas consequências. A experiência pode transformar a maneira de pensar a sociedade e os diversos agentes envolvidos.

Uma abordagem museológica diferenciada, baseada em convivências e narrativas, poderia converter o visitante em um agente transformador da própria sociedade atual, levando ao questionamento da interação social, e das relações entre os cidadãos e o governo, por exemplo. A relação mais comunitária existente nas sociedades missioneiras talvez possa ser interpretada como um modelo social mais justo e humanitário e inspirar uma reflexão sobre a sociedade atual. Em um espaço onde o visitante é convidado a entender seu passado, para analisar o presente e almejar um futuro diferente, através de experiências que despertem o afeto e a identificação com sua cultura, ao possibilitarem o diálogo entre os bens culturais representativos e os visitantes, e instigarem a reflexão em vez da mera observação passiva. Ou seja, o museu deve tomar uma concepção diferenciada para si, em que é entendido como um espaço de cidadania. Esta metodologia pode ser colocada em prática, contudo demanda infraestrutura de pessoal e formação específica que esbarram em questões administrativas e econômicas. O que não impede que seja realizada, mas ainda a atrasa. Contudo, a experiência passada de São Miguel - Brasil demonstra que é possível. Como relata Custódio (2014), na década de 1990, diversas atividades 
eram realizadas junto ao sítio com a comunidade, por exemplo, música ao entardecer antes do espetáculo noturno, atividades de educação patrimonial, filmes, maquetes, etc.

Ao analisar-se o diagrama de Mujica sobre o sistema de preservação das Missões (Figura 26, na página 106), percebem-se as conexões entre os diversos bens patrimoniais materiais e imateriais para a formação de um entendimento sobre este período histórico. Através da inclusão de um nível mais externo a este mesmo diagrama que representa os agentes responsáveis pela preservação, também é possível notar a importância da dimensão humana do sistema, responsável pela necessidade de preservação do patrimônio. E, também, a relevância destas atividades de criação de elos com o patrimônio. Isto porque, se estes agentes não exercerem suas funções; em especial se a comunidade não se apropriar deste patrimônio, não perceber seu valor e sua significância - o que ocorre por meio das ações realizadas pelos outros agentes; não existe razão para a permanência do patrimônio. Nas palavras do arqueólogo italiano Maurizio Forte (2007, p. 398, tradução nossa ${ }^{79}$ ), “Um patrimônio não perceptível e não percebido é desnarrativo, destituído de conexões e contextos". Desse modo, é necessário que o diálogo entre os agentes ocorra de maneira efetiva, de modo que o conhecimento produzido pelos pesquisadores e órgãos responsáveis circule entre eles e deles para o guia de turismo, que deve ser bem-formado para a importante função de servir como ponte entre este conhecimento e a comunidade. Além disso, deve haver outros meios de acesso à informação e a possibilidade de diálogo em todos estes níveis de comunicação, de modo que guias e comunidade sejam convidados a participar de uma produção coletiva do conhecimento.

\footnotetext{
${ }^{79}$ Do original em inglês: "[...] A cultural heritage not perceptible and no perceived is denarrative, destitute of connections and contexts" (FORTE, 2007, p. 398).
} 
Segundo Biesek (2009), o pleno desenvolvimento turístico e econômico da região missioneira está vinculado à construção de uma visão comum entre os administradores e demais agentes nacionais, como já vinha sendo praticado na década de 1990. Além disso, esta pesquisa entende que também depende do próprio entendimento do patrimônio missioneiro como o sistema complexo que constitui.

Neste sentido, é preciso reavivar a atuação da Comissão Técnica do Patrimônio do Mercosul, pois a criação deste conselho internacional com representantes de cada um dos países, voltado para assistência técnica, compartilhamento e produção de conhecimentos na área de conservação foi de grande importância. Mesmo não podendo tomar decisões interventivas e administrativas, esta comissão pode aconselhar sobre a adequação ou não de propostas realizadas pelos Estados nacionais em relação ao patrimônio compartilhado. Além disso, através desta comissão é possível somar esforços nacionais para a criação de conteúdo mais aprofundado para a divulgação, e tratar de questões administrativas de promoção e organização dos sítios históricos.

Dessa forma, através de uma transparência de informações e de uma tomada integrada de decisões, os órgãos responsáveis podem ser libertados de algumas amarras impostas pelas estruturas burocráticas, que retardam as ações de intervenção e preservação. De acordo com os museólogos brasileiros Francisco de Sá Neto e Cláudio Guerra (2013), a virtualização concebe uma maneira diferenciada de gestão pública do patrimônio, onde o trabalho em rede possibilita, além de outras vantagens, a redução de custos com aquisição de materiais e prestação de serviços. Também possibilita uma interação não limitada pela geografia e pelo tempo entre as instituições interessadas, públicas e privadas, administrativas e de pesquisa. Acervos online como o projeto realizado na década de 1990 em parceria entre o IPHAN e a IBM alcança uma abrangência em 
termos de número de pessoas e extensão geográfica que pode contrabalancear o pequeno número de remanescentes e o estado precário em que se encontram, além de eliminar as fronteiras entre eles e amplificar o trabalho do grupo de pessoas envolvidas em todos os âmbitos relacionados à preservação deste patrimônio.

Como enfatiza Biesek (2009), os benefícios de um gerenciamento integrado deste patrimônio em comum seriam vários. Dentre eles, pode-se destacar a melhoria das relações entre os diversos profissionais e o consequente aumento do número de trabalhos realizados de maneira conjunta; além do fortalecimento do comércio e dos serviços e da qualificação da mão-de-obra na região. Alguns destes aspectos foram citados como importantes pelos próprios representantes nacionais no "Programa de Capacitação para Conservação, Gestão e Desenvolvimento Sustentável das Missões Jesuíticas dos Guarani" (2000 a 2003): o estabelecimento de uma documentação centralizada voltada à conservação dos registros e à maior divulgação dos mesmos; o fortalecimento do sentimento de apropriação deste patrimônio pela comunidade e de sua sensibilização sobre sua importância; e a apresentação uniformizada da história passada e atual das Missões de modo a facilitar sua compreensão (CUSTÓDIO; BRUXEL, 2004, p. 33-37).

No mesmo evento, enfatizou-se que a preservação das Missões Jesuíticas constitui uma oportunidade única para criar uma maneira diferenciada de gerenciar e entender o patrimônio, baseada em uma abordagem integrada entre os diversos sítios históricos e os agentes dos países envolvidos. E esta metodologia internacional e integrada de tratamento do patrimônio pode ser utilizada não somente para a preservação mais eficiente das Missões Jesuíticas, mas para qualquer conjunto patrimonial mundial.

Neste sentido, esta pesquisa entende que as mídias digitais podem atuar como ferramentas de gerenciamento deste sistema, não somente para o armazenamento e a disseminação dos 
dados, mas também como espaço de incentivo a uma produção coletiva de conhecimento. Além disso, elas possibilitariam a ampliação da visão do patrimônio através de bases de dados mais completas e reflexões tão profundas quanto as realizadas durante a contemplação em espaços museológicos. Contudo, ainda são poucas as ações desta natureza, mesmo em âmbito nacional. No próximo capítulo serão apresentadas as ações online já realizadas, com a finalidade de obter uma visão geral do estado atual. Em seguida, serão analisadas formas para aprimorar tais ações, através de ferramentas online já existentes, com a finalidade de entender a utilidade e importância das mídias digitais para a preservação integrada do patrimônio missioneiro, e apontar possibilidades para esta abordagem diferenciada. 
150 


\section{CAPÍTULO 3}

COMO MANTER UM SISTEMA VIVO

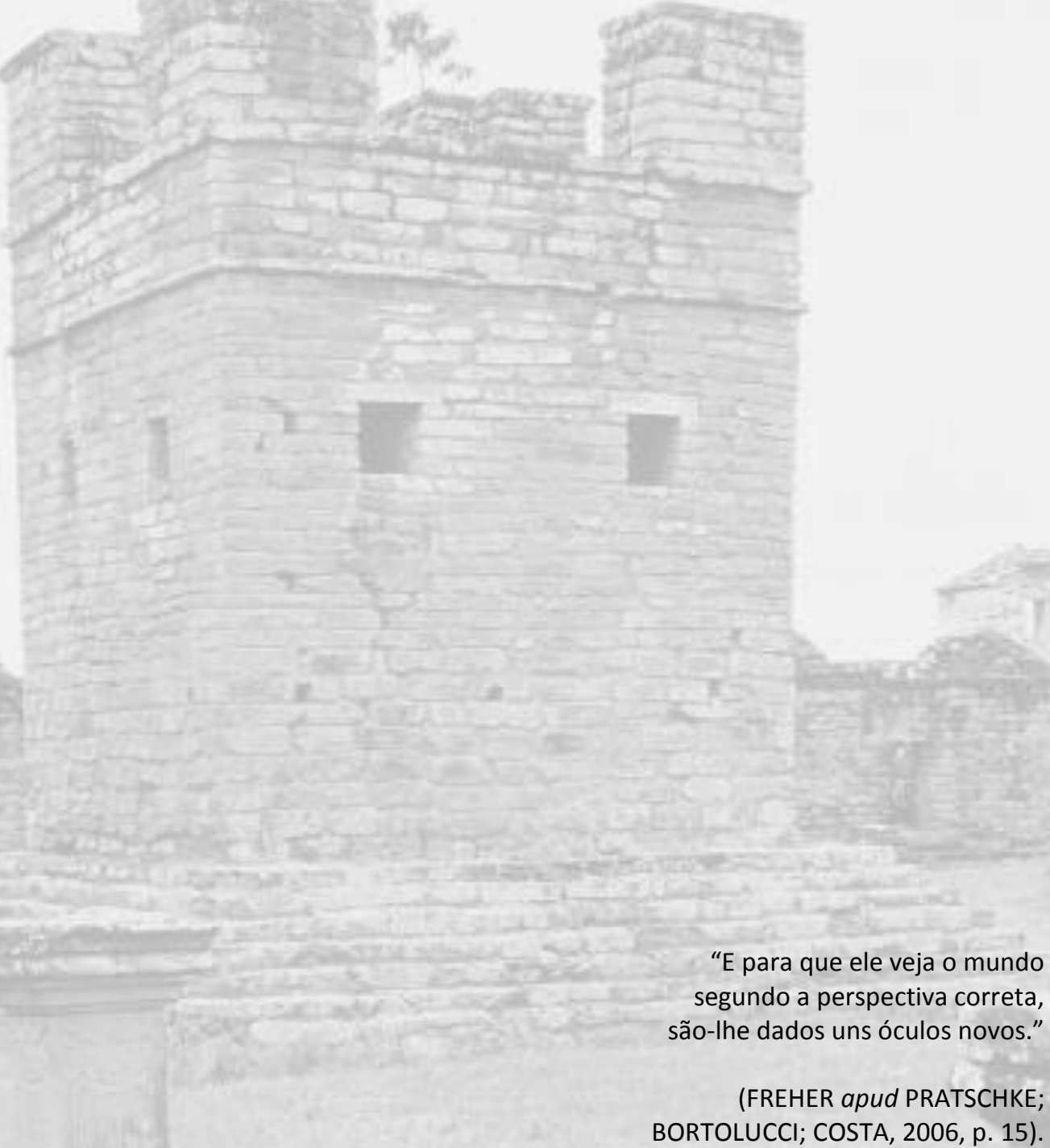


Este capítulo refere-se ao pilar museológico da divulgação do patrimônio e nele é discutida a representação do patrimônio em meio virtual, suas consequências e potencialidades. É realizada uma discussão sobre o uso de tecnologias de informação e comunicação para organizar e colocar em evidência questões, necessidades e ações relacionadas à preservação das Missões Jesuíticas como um sistema vivo, entendido como aquele em que as interações entre os agentes e destes com o patrimônio é realizada de modo efetivo, justificando a relevância da preservação em um contexto glocal. Apresenta-se também uma análise da utilização de plataformas digitais para o registro do patrimônio, a preservação e a educação no âmbito dos órgãos de preservação das Missões Jesuíticas, com a finalidade de se entender o estado atual da divulgação online, suas principais características e seus pontos positivos e negativos.

Ao final deste capítulo, lança-se um olhar para fora do contexto das Missões a fim de buscar possíveis ferramentas digitais para o tratamento do patrimônio de maneira integrada, propondo outra abordagem possível para os sítios históricos missioneiros, que poderia atuar como

\begin{abstract}
uma base de dados integradora de vários centros, patrimônios arquitetônicos e museus. Buscando manter vivas as dinâmicas culturais da comunidade, a preservação e o acesso físico e virtual a tais patrimônios, contribuem para a valorização das culturas tradicionais, e reforçam o sentimento de pertencimento e de identidade, garantindo consequentemente a permanência desse patrimônio para as futuras gerações (PRATSCHKE; SANTIAGO, 2006, p. 1).
\end{abstract}

O propósito final desta análise é aprimorar a preservação do patrimônio missioneiro através da indicação de uma abordagem para as ações necessárias pontuada pelo intermédio da organização das informações e da comunicação a partir de plataformas digitais. Entende-se que as mídias digitais podem auxiliar a comunicação entre todos os agentes, promovendo e possibilitando suas interações tão essenciais para a preservação do patrimônio, integrando e fazendo interagir história, memória e patrimônio através do patrimônio material e imaterial e do conhecimento reunido pelos agentes envolvidos: comunidade, órgãos responsáveis, guias de turismo e pesquisadores.

Imagem da página anterior: Trinidad - Paraguai (CHAROLA; MAGADÁN, 2009, p. 187). 
Como mencionado no capítulo anterior, a atuação dos órgãos de preservação dos sítios históricos missioneiros está basicamente pautada em ações locais e nacionais, onde cada cidade/país é responsável por seus remanescentes e incentiva, conforme possível, um roteiro nacional de visitação. Apesar desta abordagem nacional atual, a importância do patrimônio missioneiro como o conjunto de vestígios móveis e imóveis presentes nos sítios históricos e sua história e cultura é reconhecida pelos órgãos responsáveis (WORLD MONUMENTS FUND, 2004).

Este patrimônio desempenha papel social fundamental, pois

[...] Informações culturais podem reunir comunidades, assim como promover o entendimento de uma cultura e sociedade. [...] [Por isso,] $O$ acesso à documentação histórica que sustenta uma sociedade não deveria mais ser um privilégio ou um agradável passatempo para uns poucos com permissão, mas um direito básico para todos. [...] (LIEW, 2005, p. 4, tradução nossa ${ }^{80}$ )

Dessa maneira, é essencial para a própria cidadania e integração permitir o acesso da população a essas fontes de informações imprescindíveis à manutenção da identidade de uma sociedade, sendo, portanto, urgente a adoção de medidas que ampliem a divulgação das Missões Jesuíticas a fim de sanar questões como o desconhecimento e a consequente desvalorização deste patrimônio por parte das comunidades locais, mencionadas por Nogueira (2000, apud CARNEIRO FILHO; SANTOS, 2012). Para tanto, entende-se que é necessário alterar o olhar lançado

\footnotetext{
${ }^{80}$ Do original em inglês: "[...] Cultural information can bring communities together, as well as promoting the understanding of a culture and society. [...] Access to historical documentation underpinning a society should not be a privilege or a pleasant pastime for an affordable few, but a basic right for all. [...]" (LIEW, 2005, p. 4).
} 
sobre este sistema a fim de compreendê-lo como um todo formado pelos vários sítios históricos e seus remanescentes, em uma abordagem global que possa reunir e integrar patrimônio, informação e agentes. Mas como seria possível realizar tal objetivo, sobrepujando as barreiras geográficas, econômicas e políticas existentes de maneira eficiente, rápida e sem altos custos?

Segundo o filósofo tcheco Villém Flusser (2008, p. 26),

[...] O homem é ente que, desde que estendeu a sua mão contra o mundo, procura preservar as informações herdadas e adquiridas, e ainda criar informações novas. Esta é a sua resposta à "morte térmica", ou, mais exatamente, à morte. "Informar!" é a resposta que o homem lança contra a morte. [...] O propósito dos aparelhos é o de criar, preservar e transmitir informações.

Ao longo da história, o registro e a transmissão das informações referentes ao conhecimento, às lembranças e aos valores de uma sociedade ao longo das gerações ocorrem através do que Flusser chamava de aparelhos, entendidos aqui como todos os meios de comunicação, suportes de memória, desde a oralidade das sociedades ágrafas até os meios eletrônicos e digitais recentes (LE GOFF, 2003). Fenômeno que foi continuado e intensificado com o surgimento dos computadores em 1945. Seus usos vêm se ampliando e diversificando, em um "movimento geral de virtualização da informação e da comunicação" (LÉVY, 1999, p. 31), que não poderia ter sido previsto no momento de sua concepção e que foi impulsionado pelo desenvolvimento do microprocessador em meados dos anos 1970, possibilitando o barateamento dos computadores e, consequentemente, sua venda para um maior número de pessoas em um curto período de tempo. "[...] enquanto o rádio levou trinta anos para atingir os lares de 50 milhões de norteamericanos e a televisão treze anos para alcançar a mesma estatística, a internet levou apenas quatro anos" (HABERMAS, 2005, p. 18). 
A interação entre as áreas de engenharia, informática e comunicação proporcionou a ascensão de um ambiente tecnológico onde as tecnologias inteligentes (como denominadas por LÉVY, 2001) culminaram em um novo lugar de habitação: o chamado ciberespaço. Através de tecnologias computacionais produzem-se ambientes online de aprendizado, onde os cenários agregam enorme gama de dados (hiperlinks), oferecendo um âmbito diferenciado de contextualização dos objetos. De tal forma que, para o filósofo da informação francês Pierre Lévy (1999, p. 145), "poderíamos chamar o artista da cibercultura [...] de um engenheiro de mundos. Ou seja, alguém que vai designar, [...] não uma mensagem, mas um universo de interação".

Nos dias atuais, computadores e Internet estão distribuídos por todo o mundo e "[...] possibilitam a disseminação da informação de forma instantânea a um maior número de pessoas em relação a qualquer outro meio de comunicação [anterior] [...]" (LIMA; PRETTO; FERREIRA, 2005 , p. 243). Isso porque, em nossa sociedade da informação, a comunicação acontece em tempo real e de forma não presencial, de modo que o contato entre os indivíduos e deles com o conhecimento é realizado independentemente da distância entre receptor e emissor (CASTELLS, 2003). Segundo o arquiteto norte-americano Nicholas Negroponte (1995, p. 10), na forma digital

[...] a informação pode se tornar acessível para todos. Thomas Jefferson nos legou o conceito de bibliotecas públicas e o direito de consultar um livro de graça. Mas esse nosso grande antepassado jamais considerou a possibilidade de 20 milhões de pessoas terem acesso eletrônico a uma biblioteca digital, podendo retirar dela o material desejado sem nenhum custo.

A velocidade e a quantidade de informação acumulada e compartilhada vêm aumentando exponencialmente. Como enfatiza Lévy (1999, p. 47), o virtual, por ser uma entidade desterritorializada, é "[...] capaz de diversas manifestações concretas em diferentes momentos e locais determinados, sem contudo estar ela mesma presa a um lugar ou tempo em particular. 
[...]". Já o doutor em Filosofia canadense Marshall McLuhan (1979 [1964], p. 110) acredita que “[...] A velocidade elétrica cria centros por toda parte. As margens já não mais existem neste planeta". Pode-se entender então que a internet transformou-se no maior centro de armazenamento para o conhecimento humano produzido em todas as partes do mundo, e possibilita que ele seja acessado de qualquer parte dele. Dessa forma, devido às mídias digitais qualquer lugar do mundo é tanto um centro de produção como de acesso ao conhecimento. Porque "[...] No centro das redes digitais, a informação certamente se encontra fisicamente situada em algum lugar, em determinado suporte, mas ela também está virtualmente presente em cada ponto da rede onde seja pedida" (LÉVY, 1999, p. 48). Neste contexto, "[...] O computador não é mais um centro, e sim um nó, um terminal, um componente da rede universal calculante [...]" (LÉVY, 1999, p. 50). Desfazem-se os limites espaço-temporais do conhecimento.

Esse ambiente virtual é um sistema complexo como o patrimônio, onde se conforma "uma representação de aspectos do mundo físico que passam a ser experienciáveis pelos usuários" (SANTOS, 2005, p. 2). Ou seja, o virtual é um local onde a visão do concreto pode ser ampliada de maneira que o físico e o virtual se complementem (SANTIAGO, 2007). Para Forte (2007), os dois espaços possuem suas peculiaridades e essas aplicações devem ser orientadas na direção de mudar os modos e as abordagens do aprendizado e da disseminação do conhecimento. $\mathrm{O}$ autor ainda salienta que "[...] O real e o virtual não são ecossistemas opostos, mas ontologias paralelas na percepção e nas inter-relações da informação" (FORTE, 2007, p. 392, tradução nossa ${ }^{81}$ ). Segundo ele,

\footnotetext{
${ }^{81}$ Do original em inglês: "[...] Real and Virtual are not opposed ecosystems, but parallel ontologies in the perception and interrelations of information" (FORTE, 2007, p. 392).
} 
Uma ontologia da conectividade envolve uma causalidade mútua - ator e ambiente modificam um ao outro, criando informações novas. Na relação entre mapa e território - presumindo o Virtual, o mapa, e o território como itens do conhecimento - a transferência de informação entre mapa e território e viceversa pode ser vista na relação circular da interação "mapa-território", entre informações codificadas e não-codificadas.

Conhecimento e aprendizado do "mapa" podem produzir um novo conhecimento do território e, como consequência disto, o conhecimento do território produzirá um conhecimento ainda mais novo do mapa. A permuta de informação entre o mapa e o território é bidirecional e representa muito bem as relações entre o real (território) e o virtual (mapa) (FORTE, 2007, p. 397, tradução nossa ${ }^{82}$ ).

\section{O território e o virtual compartilham informações e contextos em uma comunicação}

contínua, onde ambos renovam-se um ao outro através da produção de conhecimentos. Segundo os engenheiros da computação gregos Eugenia Politou, George Pavlidis e Christodoulos Chamzas (2004, p.1, tradução nossa $\left.{ }^{83}\right)$,

Com a aplicação das últimas tecnologias em compressão de imagem para a gestão do armazenamento de dados massivos de imagem dentro das bases de dados do patrimônio e com a exploração da universalidade da Internet, agora

${ }^{82}$ Do original em inglês: "An ontology of the connectivity involves a mutual causality - actor and environment modify each other, creating new information. In relation between map and territory - presuming the Virtual, the map, and the territory as items of knowledge - the transfer of information between map and territory and vice versa can be seen in the circular relation of the interaction "map-territory", between coded and uncoded information.

Knowledge and learning of the "map" can produce a new knowledge of the territory and, as a consequence of this, knowledge of the territory will produce a newer knowledge of the map. The informative exchange between map and territory is bidirectional and it represents very well the relations between real (territory) and virtual (map)" (FORTE, 2007, p. 397).

${ }^{83}$ Do original em inglês: "By applying the latest technologies in image compression for managing the storage of massive image data within cultural heritage databases and by exploiting the universality of the Internet, we are now able not only to digitize, record and preserve cultural heritage effectively, but also to promote its dissemination" (POLITOU; PAVLIDIS; CHAMZAS, 2004, p. 1). 
somo capazes de digitalizar, registrar e preservar o patrimônio cultural efetivamente, mas também de promover sua disseminação.

A representação que, segundo o historiador brasileiro Nicolau Sevcenko (1993, p. 100), é a tradução do concreto para o virtual, é um conceito muito importante para a área do patrimônio e, consequentemente, para a questão da preservação e divulgação das Missões Jesuíticas. De acordo com o autor, representar é converter o concreto em uma forma de linguagem, criando um elo entre suas duas formas: a concreta e a virtual.

[...] Uma, a percepção e recorte daquele segmento específico da realidade, outra, a da sua interpretação e tradução nos termos dos códigos simbólicos e expressivos peculiares ao meio cultural ao qual pertence o agente desse ato de reapresentação (SEVCENKO, 1993, p. 100).

Uma forma de re-apresentar o concreto para permitir seu compartilhamento facilitado através de palavras, imagens, bits ou outras formas. "No entanto, nunca devemos perder de vista o bem cultural concreto, sem o qual a simulação virtual perderia seu significado, sua alma e seu referencial. [...]" (SANTIAGO, 2008, p. 3), da mesma forma como as interações entre os agentes não ocorreriam sem a presença do patrimônio, como mencionado no capítulo anterior. O elo mencionado por Sevcenko é essencial para o entendimento da própria representação, que funciona apenas como um mapa do território concreto, mas não o substitui. Sendo um dos princípios básicos da cibernética (FORTE, 2007), “Um mapa não é uma foto realista, mas uma semiotização, uma descrição útil de um território. Por analogia, um mundo virtual pode ser da família dos mapas e não da família das cópias ou das ilusões. [...]” (LÉVY, 1999, p. 72). O mapa não deve pretender conter em si a totalidade do território, pois, como mencionado, a representação pressupõe a criação de um recorte do concreto. Antes de ser uma cópia do território, o mapa tem a potencialidade de retratar parte dele e esmiúça-la, agregando informações não contidas de maneira explícita no concreto, podendo ampliar o entendimento de uma parcela dele. 
Em relação às Missões Jesuíticas, pode-se dizer que as informações disponibilizadas através da internet (imagens, história, cultura, textos, entre outras) representam apenas parcelas da realidade dos sítios e deste processo histórico. Sendo mapas que não representam a totalidade do território. Contudo, quando as informações são reunidas, comparadas e interligadas, proporcionam uma visão ampliada deste patrimônio pela possibilidade de agregar informações não contidas nos monumentos e de reconstruir aspectos visuais e textuais importantes para seu melhor entendimento.

Conforme, o arquiteto brasileiro Rodrigo Peronti Santiago (2008, p. 3), “Entre o mapa (o virtual) e o território (o concreto), se estabeleceria uma retroalimentação informativa (feedback), que geraria um novo conhecimento". Este conhecimento será um produto aberto, fruto de um sistema aberto, caracterizado por análises e entendimentos pessoais sobre o concreto e pela colaboração entre pesquisadores de diversas áreas. Contudo, como enfatizam as cientistas da informação brasileiras Vivian Moreira e Lucília Romão (s.d., s.p.),

Falar sobre a Internet implica considerar as condições de produção de uma outra discursividade, diferente daquela inscrita pelo impresso, agora afetada e mediada pela tecnologia, sustentada por um imaginário de acessibilidade infinita e constituída na relação dos sujeitos com uma (nova) ordem de potência. [...].

Estimula uma discursividade permeada pela possibilidade de inter-relações entre conteúdos e usuários através de links e ferramentas de comunicação e é capaz de potencializar olhares diferenciados sobre os monumentos, discussões mais embasadas sobre a história e ampliações de entendimentos sobre as sociedades. Neste contexto, é interessante analisar as relações entre os meios de comunicação e os espaços museológicos. Segundo os historiadores ingleses Asa Briggs e Peter Burke (2004, p. 193), 
[...] a importância da informação naquilo que se tornou quase uma tríade sagrada - informação, educação e entretenimento - foi completamente reconhecida, muito antes da popularização dos termos "sociedade da informação" e "tecnologia da informação", durante as décadas de 1970 e 1980.

Esta tríade da informação pode aliar forças com os pilares museológicos -pesquisa, conservação e divulgação-, de modo que existem duas instâncias em que os museus podem incluir a virtualização em seus processos: uma interna, com aplicativos que podem ser acessados unicamente no ambiente do museu ou com recursos eletrônicos próprios; e outra, externa, através da disponibilização de conteúdo online através de um portal da instituição, por exemplo. Nestas instâncias é interessante introduzir os elementos organizacionais definidos por Marchiori (apud CAMARGO; SANTOS, 2005, p. 340) como: biblioteca eletrônica (envolve processos básicos, índices on-line, na busca de textos completos e na recuperação e armazenamento de registros; armazenagem, recuperação e disponibilidade de informação; digitalização de livros), biblioteca digital (possui informações existentes apenas na forma digital) e biblioteca virtual (reproduz o ambiente de uma biblioteca em duas ou três dimensões).

Como conteúdo destas bibliotecas deve-se entender não somente a representação de coleções de livros, mas também de qualquer acervo museológico, como, por exemplo, das estátuas de madeira presentes no Museu das Missões em São Miguel - Brasil. Devido a sua importância como meio de divulgação, a criação destes espaços museológicos virtuais tem-se tornado comum para ampliar o acesso da população aos acervos das instituições mantenedoras (MACDONALD, 2006). O que, no caso das Missões Jesuíticas, amenizaria a questão da falta de conhecimento das comunidades envolvidas, proporcionando uma identificação das mesmas com sua cultura e história, e, consequentemente, uma preservação mais efetiva através deste sentimento de pertencimento. 
Uma plataforma online $e^{84}$ unificadora das Missões Jesuíticas incentivaria e possibilitaria as interações necessárias entre os agentes e destes com o conhecimento para a efetividade do sistema de preservação missioneiro. Estes agentes envolvidos nestas interações podem ser classificados em dois grupos: 1. a comunidade, guias e os órgãos responsáveis, com interesse na apresentação deste patrimônio; e 2. os pesquisadores, que estão mais preocupados com seu registro, preservação, análise e divulgação. Retomando as relações demonstradas na Figura 28 (na página 110), que retrata a importância do guia de turismo para o sistema, a inserção desta plataforma faria com que a comunicação entre os agentes fluísse de maneira mais eficiente (Figura 37, na próxima página).

Ao contrário da situação atual, em que os dados não circulam de maneira facilitada e os agentes não se comunicam entre si, intermediados por uma plataforma digital todos os envolvidos teriam a possibilidade não somente de analisar as informações disponibilizadas, mas também de alimentar o banco de dados deste sistema. Além disso, uma plataforma com funcionalidades como e-mails e chats poderia estruturar a comunicação entre eles, situação essencial para a plena execução de todas as ações necessárias para a preservação do patrimônio, retomando a interação entre os agentes dos órgãos responsáveis como na década de 1990. O que promoveria o melhor conhecimento das informações disponíveis e a criação coletiva de conhecimentos, especialmente porque para esta pesquisa a comunidade envolve não somente os visitantes dos sítios históricos, mas também as populações local e global, inclusive os indígenas

\footnotetext{
${ }^{84}$ Uma plataforma é um ambiente virtual que possibilita a produção e divulgação de conteúdo, mas que também funciona como facilitadora de comunicação entre os usuários. Enquanto o site permite ao usuário apenas visualizar a informação, a plataforma amplia sua atuação também para a criação de conteúdo e a interação com os demais envolvidos no sistema.
} 


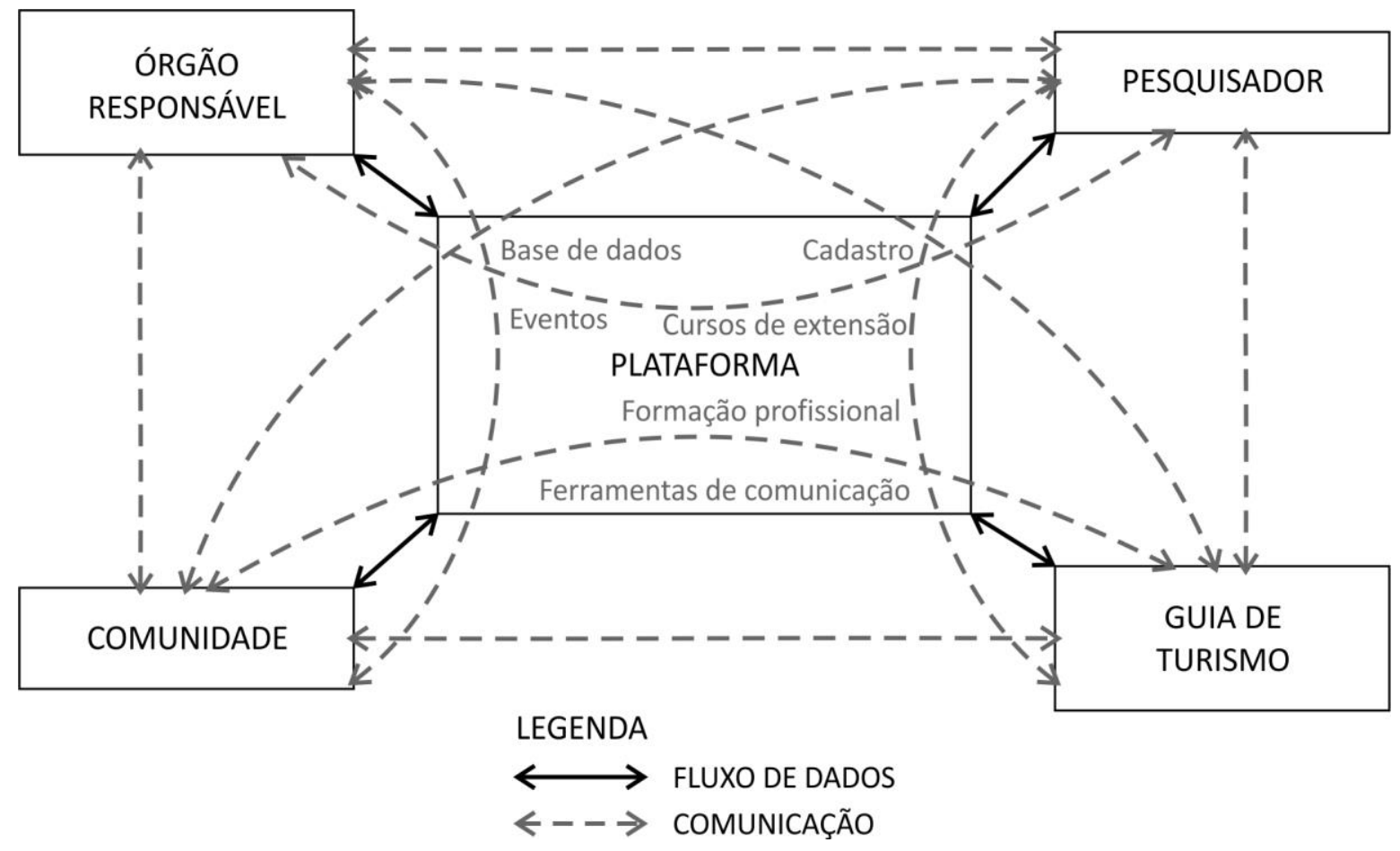

Figura 37. Relações entre os agentes proporcionadas pela inserção de uma plataforma digital no sistema de preservação.

Fonte: Elaborada pela autora. 
locais que inseririam informações importantes e insubstituíveis neste sistema.

Segundo Forte (2007, p. 395-396, tradução nossa ${ }^{85}$ ),

Pode-se dizer que na virtualidade olhamos para a desobjetificação do Real. Significados são tornados acessíveis, então aqueles novos significados, ou geometrias cognitivas diferentes, podem ser tabulados e explorados. Este tema é relevante porque envolve gerações futuras para quem a comunicação cultural e as novas memórias coletivas serão geradas através de uma relação nômade e desterritorializada com a informação.

Isso porque a Internet tem o poder não só de veicular informação sem limites geográficos, mas também de hospedar diferentes ferramentas, que podem ser integradas para auxiliarem umas às outras. Segundo Max de Mendizábal C. (2013, s.p.), diretor de tecnologias da informação da Coordinación de Universidad Abierta y Educación a Distancia da Universidad Nacional Autónoma de México,

Até poucos anos atrás, o trabalho colaborativo era impossível de ocorrer na rede. Hoje em dia, com ferramentas como a Wiki, redes sociais, documentos colaborativos do Google Docs, é cada vez mais fácil a interação entre as plataformas virtuais. A Web 2.0 plus (também chamada por alguns como Web 3.0) possibilita a interação com redes sociais e com dispositivos móveis.

Tomando emprestadas as palavras de Lévy em sua análise sobre algumas das vertentes de pensamento acerca das comunidades virtuais, a diretriz desejável de uma interface colaborativa eficiente está relacionada à valorização das contribuições individuais dos usuários e à colocação dos recursos dos grupos a serviço dos indivíduos, com o intuito de "que cada rede dê à luz um

\footnotetext{
${ }^{85}$ Do original em inglês: "One could say that in virtuality we look at the deobjectivation of the Real. Significations are opened up, so that new meanings, or different cognitive geometries, can be tabulated and explored. This theme is relevant because it involves future generations for whom cultural communication and new collective memories will be generated via a nomadic and deterritorialized relationship with information" (FORTE, 2007, p. 395-396).
} 
'grande animal' coletivo" (LÉVY, 1999, p. 131). De tal forma que pesquisadores e comunidades, "antes dispersos pelo planeta, muitas vezes isolados ou ao menos sem contatos regulares entre si, [...] [disponham] de um lugar familiar de encontro e troca" (LÉVY, 1999, p. 130).

Neste sentido, podem ser criados espaços virtuais de informação e aprendizagem que envolvem processos comunicativos de apresentação de informações, de interação entre os usuários, de produção de conteúdo e conhecimento e de exibição desta produção (CHAN NÚÑEZ, 2004, p. 10). Além disso, segundo os cientistas da computação Angelina Russo e Jerry Watkins (2007, p. 156, tradução nossa $\left.{ }^{86}\right)$, “[...] Serviços futuros nas redes podem tirar vantagem da curiosidade do público e vincular informações entre instituições. [...]". Uma abordagem que é possível porque desde os anos 1990 a informática preocupa-se com as interfaces e sua relação com os usuários finais (LEVENTHAL; BARNES, 2008). Segundo a cientista da informação Deirdre Stam (2005, p. 56), neste mesmo período as teorias que regem a museologia buscaram analisar as experiências proporcionadas. Dessa maneira, os teóricos passaram a perceber que os processos digitais de informação, apesar de estarem centrados nas máquinas, ainda possuem os indivíduos como elementos principais. A tecnologia armazena, organiza e disponibiliza as informações que foram pesquisadas, analisadas e inseridas por pessoas, para que outros indivíduos possam pesquisar, analisar, entender e retornar novos conhecimentos para este sistema. Portanto, a tecnologia é o meio, mas a força motriz ainda é o Homem.

\footnotetext{
${ }^{86}$ Do original em inglês: "[...] Future services in the networks can take advantage of audience curiosity by linking information between institutions. [...]" (RUSSO; WATKINS, 2007, p. 155).
} 
Segundo Russo e Watkins (2007, p. 155, tradução nossa ${ }^{87}$ ),

A Web oferece ao público uma oportunidade de experienciar, em primeira mão, as redes remediadas de instituições culturais e de interagir com narrativas, criando assim experiências únicas. Esta interação transforma os modos como os públicos acessam e navegam em informações culturais.

Como comentam os autores, podem-se desenvolver redes de colaboração interinstitucional, pois, assim como o território está em constante atualização, o mapa também deve estar. Do mesmo modo, as pesquisas relacionadas às Missões Jesuíticas podem produzir conhecimentos potencializados através de sua disseminação. Dessa forma, um conhecimento disponibilizado online pode servir de base para a produção de outro conhecimento, iniciando um ciclo autogerador de estímulo (dados online) e emergência (novos produtos) de novos conhecimentos que podem ser utilizados para uma mudança no espaço físico quando colocados em prática.

No caso das Missões Jesuíticas, interessa a criação de uma plataforma virtual para um tratamento inter-regional, ao contrário do que se faz atualmente onde cada país divulga seus sítios históricos e não existe um ambiente que proporcione e incentive a interação entre os agentes envolvidos nos processos relacionados à pesquisa, conservação e divulgação deste patrimônio histórico. Contudo, como salienta John Falk (2010, p. 19, tradução nossa ${ }^{88}$ ) "Não se trata de criar programas e exibições diferentes, mas trata-se de criar uma experiência diferente para o visitante", entendido aqui como o usuário da plataforma, seja ele acadêmico ou leigo. Nas

${ }^{87}$ Do original em inglês: "The Web offers na opportunity for audience to experience, first-hand, the remediated networks of cultural institutions and to Interact with narraties, thus creating unique experiences. This interaction transforms the ways in which audiences access and navigate cultural information" (RUSSO; WATKINS, 2007, p. 155).

${ }^{88}$ Do original em inglês: "It's not about creating different exhibits \& programs, it's about creating different visitor experiences” (FALK, 2010, p. 19). 
palavras do arqueólogo brasileiro Ulpiano Menezes (2007, p. 64), “Em síntese: é preciso fazer do virtual um território de exploração e não de rendição incondicional ou de sedução consentida. [...]". Um espaço em que a consciência do concreto seja ampliada e que responda de maneira positiva à questão levantada pelo autor: "[...] tem sentido, no mundo de hoje, reservar uma plataforma apta a nos dar ou aprofundar a consciência (em todas as suas dimensões) do universo físico, sensorial em que estamos imersos? [...]" (MENEZES, 2007, p. 65). Isso porque tais ambientes têm a potencialidade de "[...] mudar os modos e abordagens do aprendizado" (FORTE, 2007, p. 389) e também servir como um espaço "articulado e articulador das redes educacionais existentes, físicas e administrativas [...]" (LIMA; PRETTO; FERREIRA, 2005, p. 233). Onde a relação entre redes educacionais e instituições museológicas deve ser estreitada pelo seu papel fundamental que ambas possuem na formação identitária de uma sociedade e no entendimento que os cidadãos fazem de sua história e de seu presente.

Os ambientes virtuais poderiam promover trocas de informação mais democráticas e inteligentes, onde o conhecimento pudesse ser produzido de forma colaborativa. Isso porque se substituiria o modelo de informação unidirecional por processos produtivos pautados na comunicação bidirecional, de todos para todos (como visto na Figura 37), que "[...] asseguram a livre troca e a produção colaborativa, em que a possibilidade de universalização dos acessos aos conteúdos digitais é apenas um dos fatores a ser considerado. [...]" (PRADO; NOVAES, 2005, p. 45). Nas palavras de Lévy (1999, p. 166),

Precisamente, o ideal mobilizador da informática não é mais a inteligência artificial (tornar uma máquina tão inteligente quanto, talvez mais inteligente que um homem), mas sim a inteligência coletiva, a saber, a valorização, a utilização otimizada e a criação de sinergia entre as competências, as imaginações e as energias intelectuais, qualquer que seja sua diversidade qualitativa e onde quer que esta se situe. Esse ideal da inteligência coletiva passa, evidentemente, por uma prática banalizada de troca dos conhecimentos, 
por novas formas de organização e de coordenação flexíveis e em tempo real. $[\ldots]$.

Tal reconstrução dos espaços é resultado de um processo que produz lugares em que grupos de diferentes sociedades podem expor e ampliar suas culturas, colocando-as em interação com outras. Uma plataforma que permite a comunicação entre os distintos e a produção de outro olhar sobre eles, pautado em interpretações divergentes que se somam com a finalidade de formar um entendimento outro acerca das diferenças e semelhanças. Um espaço que incentiva a troca de informações e olhares entre os desconhecidos, do individual sobre/para o coletivo e viceversa (HAZAN, 2001). Nas palavras de Lévy (1999, p. 49),

[...] O ciberespaço encoraja um estilo de relacionamento quase independente dos lugares geográficos (telecomunicação, telepresença) e da coincidência dos tempos (comunicação assíncrona). Não chega a ser uma novidade absoluta, uma vez que o telefone já nos habituou a uma comunicação interativa. Com o correio (ou a escrita em geral), chegamos a ter uma tradição bastante antiga de comunicação reciproca, assíncrona e à distância. Contudo, apenas as particularidades técnicas do ciberespaço permitem que os membros ordenem, cooperem, alimentem e consultem uma memória comum, e isto quase em tempo real, apesar da distribuição geográfica e da diferença de horários. [...].

Como já antecipava Negroponte em 1995 (p. 159),

Do mesmo modo como o hipertexto remove as barreiras da página impressa, a era da pós-informação vai remover as barreiras da geografia. A vida digital exigirá cada vez menos que você esteja num determinado lugar em determinada hora, e a transmissão do próprio lugar vai começar a se tornar realidade.

Uma transmissão do lugar através de sua representação em dados multimídia, que possibilita uma telepresença e uma ampliação de seu entendimento, pois as informações existentes nas bases de dados são potenciais construtoras de conhecimento. De modo que o mapa virtual não 
anula o território físico, mas, ao contrário: ao se criar um elo entre as duas instâncias, as informações presentes no virtual incentivam a visitação do local concreto. Nas palavras de Santiago (2008, p. 3),

[...] o patrimônio cultural a ser traduzido à espacialidade virtual não deveria nunca perder sua referência concreta, pois essa ação faz parte de um processo de estabelecimento de valores e significados que se quer preservar do objeto concreto. Sem ele, não se estabeleceria a geração de novos saberes da mesclagem entre o concreto e virtual.

Esta forte relação entre virtual e concreto enfatiza a importância da preservação dos sítios históricos e das coleções museológicas, pois a existência do físico corrobora as informações online e estimula o usuário a conhecê-las fisicamente. Neste sentido, o sociólogo brasileiro Sérgio Amadeu da Silveira (2010, p. 1) comenta que "É preciso avançar na tentativa de compreender a relação entre a informação e o espaço físico, entre o ciberespaço e os locais de presença, bem como, entre o presencial e o espaço virtualizado [...]". Levando em consideração que as experiências físicas e virtuais são diferenciadas, não se substituem, mas se complementam; é possível e preciso utilizar a potencialidade do virtual para ampliar o físico. Isso porque, segundo a arquiteta brasileira Julieta Leite $\left(2005\right.$, p. 3, tradução nossa $\left.{ }^{89}\right)$,

[...] Em relação aos valores patrimoniais, a virtualização é um modo poderoso de transmiti-los, porque o meio digital representa, transmite e reproduz de maneira mais fácil esses valores do que os outros tipos de mídia. O ciberespaço aumenta enormemente a possibilidade de comunidades diferentes

\footnotetext{
${ }^{89}$ Do original em inglês: "In fact, cyberspace provides a space for new social relationships and productions, and, thus for producing values, codes of conduct and knowledge. New symbolic systems are created, even when some of them are closely related to those of the original reality. As to heritage values, virtualization is a powerful way to transmit them, because digital media more easily represent, transmit and reproduce these values than other kinds of media. Cyberspace increases enormously the possibility of different communities sharing each other's distinct and specific cultural processes, and by putting their cultures in mutual contact makes them more active in cultural processes and in enlarging the cultural base of symbols, codes and values" (LEITE, 2005, p. 67).
} 
compartilharem os processos culturais distintos e específicos de cada uma, e ao colocarem suas culturas em contato mútuo, fazem-nas mais ativas nos processos culturais e em ampliar a base cultural de símbolos, códigos e valores.

Segundo Silberman (2005, p. 9, tradução nossa $\left.{ }^{90}\right)$,

Nosso legado, nosso patrimônio, e nossa responsabilidade profissional como tecnólogos do patrimônio cultural, residem não somente em gigabytes e pixels - mas também em desenvolver dramaticamente o próprio significado do patrimônio. [...] em inúmeros websites e bases de dados arqueológicas online, o passado tem se tornado uma realidade virtual sempre-presente que é simultaneamente mais real e mais virtual do que nunca. [...] o passado é agora visto como um recurso para o desenvolvimento econômico de comunidades locais e regiões, um meio de identidade cultural e comunicação cultural cruzada, um destino edificante para os turistas culturais, e um foco para o enriquecimento educacional. [...].

O que se poderá chamar de onipresença do meio digital configura uma de suas vantagens fundamentais, pois, quando utilizado para a divulgação do patrimônio, cria "[...] cenários favoráveis ao protagonismo histórico de grupos, comunidades, povos, até então condenados à marginalidade cultural ou à segregação política" (MELO, 2005, p. 12). Portanto, atua como importante meio de disseminação da cultura, da história e da identidade de uma comunidade e é potencialmente incentivador do turismo aos lugares históricos, o que intensifica a preservação destes locais e a reflexão sobre eles e a imaterialidade que representam.

\footnotetext{
${ }^{90}$ Do original em inglês: “Our legacy, our patrimony, and our professional responsibility as cultural heritage technologists, lie not only in gigabytes and pixels - but also in the dramatically evolving social significance of heritage itself. [...] in countless websites and on-line archaeological databases, the past has become an ever-present virtual reality that is simultaneously more real and more virtual than ever before. [...] the past is now seen as a resource for the economic development of local communities and regions, a medium for cultural identity and cross cultural communication, an edifying destination for cultural tourists, and a focus for educational enrichment [...]" (SILBERMAN, 2005, p. 9).
} 


\subsection{Panorama online das Missões}

O acesso ao patrimônio das Missões Jesuíticas é realizado basicamente de modo físico e os órgãos de proteção das Missões não possuem uma plataforma virtual, nem para uso nacional, nem para a promoção da interação entre os países envolvidos. Os poucos trabalhos existentes em âmbito virtual podem ser classificados em três categorias: base de dados, reconstituições virtuais e portais na internet.

Sobre a primeira categoria, cabe mencionar que em 1987 foi realizado pelo IPHAN o levantamento da imaginária missioneira e os dados referentes a este levantamento foram disponibilizados online (Custódio, 2014). Além disso, como mencionado no capítulo anterior, na década de 1990, realizaram-se muitas atividades relacionadas à divulgação da história e do patrimônio missioneiros em São Miguel - Brasil. Dentre estas ações, destaca-se um projeto pioneiro para sua época, realizado através de parceria entre o IPHAN e a IBM para a criação de uma base de dados sobre os Trinta Povos (CUSTÓDIO, 2014), que esteve disponível online por vários anos. Na época, outros dois lugares do mundo realizavam ações desta mesma natureza, sendo um deles o Projeto de Informatização de Pompéia, na Itália (CORREIO, 1998). De acordo com notícia veiculada em jornal do estado (CORREIO, 1998), o projeto de informatização das Missões Jesuíticas envolvia três produtos: um CD-ROM sobre o Circuito Internacional Missões Jesuíticas dos Guarani, um site sobre as Missões Jesuíticas dos Guarani e o referido banco de dados. Segundo a mesma fonte, todos estes produtos seriam integrados no Centro de Documentação e Pesquisa que seria construído em São Miguel. De acordo com Custódio (2014), responsável técnico do escritório do IPHAN em São Miguel na época do projeto, as obras não 
foram concluídas e o projeto se perdeu, assim como os esforços direcionados para a construção da base de dados.

Já acerca da segunda categoria, pode-se apontar que foram realizadas reconstituições virtuais dos sítios missioneiros de São Miguel - Brasil e de San Ignácio Miní - Argentina (Figura 38, na próxima página). Este trabalho foi realizado em São Miguel na década de 1990 quando se iniciaram as atividades de educação patrimonial neste país. A reconstituição foi coordenada pela arquiteta brasileira Profa. Dra. Isabel Amalia Medero Rocha, desenvolvida de 1990 a $2002^{91}$ pela equipe do Núcleo de Computação Gráfica - Centro de Ciências Exatas e Tecnológicas da Unisinos, em parceria com o IPHAN (ROCHA, 2008, p. 9). Contudo, este material não está disponível na rede, mas em DVD e também possui pouca resolução para os padrões atuais de imagem, já que foi realizado com as técnicas disponíveis da época. Enquanto isso, a reconstituição da missão de San Ignácio Miní em modelo virtual foi realizada em 2007, mais de uma década após o projeto brasileiro, a partir de intensa pesquisa financiada pela Fundación Telefónica, como trabalho comemorativo para a inauguração do Centro de Interpretação de San Ignácio - CISI (Ayala, 2014).

Segundo a engenheira portuguesa Rosa Ferreira (1999), esta forma de registro produz uma imagem fidedigna do patrimônio, que garante a salvaguarda do conhecimento sobre ele. Além disso, a autora salienta que o registro multimídia pode ser utilizado para informar e formar a comunidade. Apesar disto, as imagens das Reduções Jesuíticas produzidas em meio digital através

\footnotetext{
${ }^{91}$ Segundo Rocha (2008, p. 2), "Embora a modelagem básica utilizada em 2001, tenha sido a original executada em 1991, as possibilidades advindas das novas versões de Autocad e 3Dstudio, fizeram com que houvesse um aprimoramento em relação às texturas, cores e às simulações tridimensionais e dinâmicas". "Este projeto amplamente divulgado na década de 90, pelo seu ineditismo, reaparece em 2001 com outra estruturação conceitual e criativa, através de produto multimídia encartado no livro Missões, editado pela UNISINOS" (ROCHA, 2008, p. 3).
} 

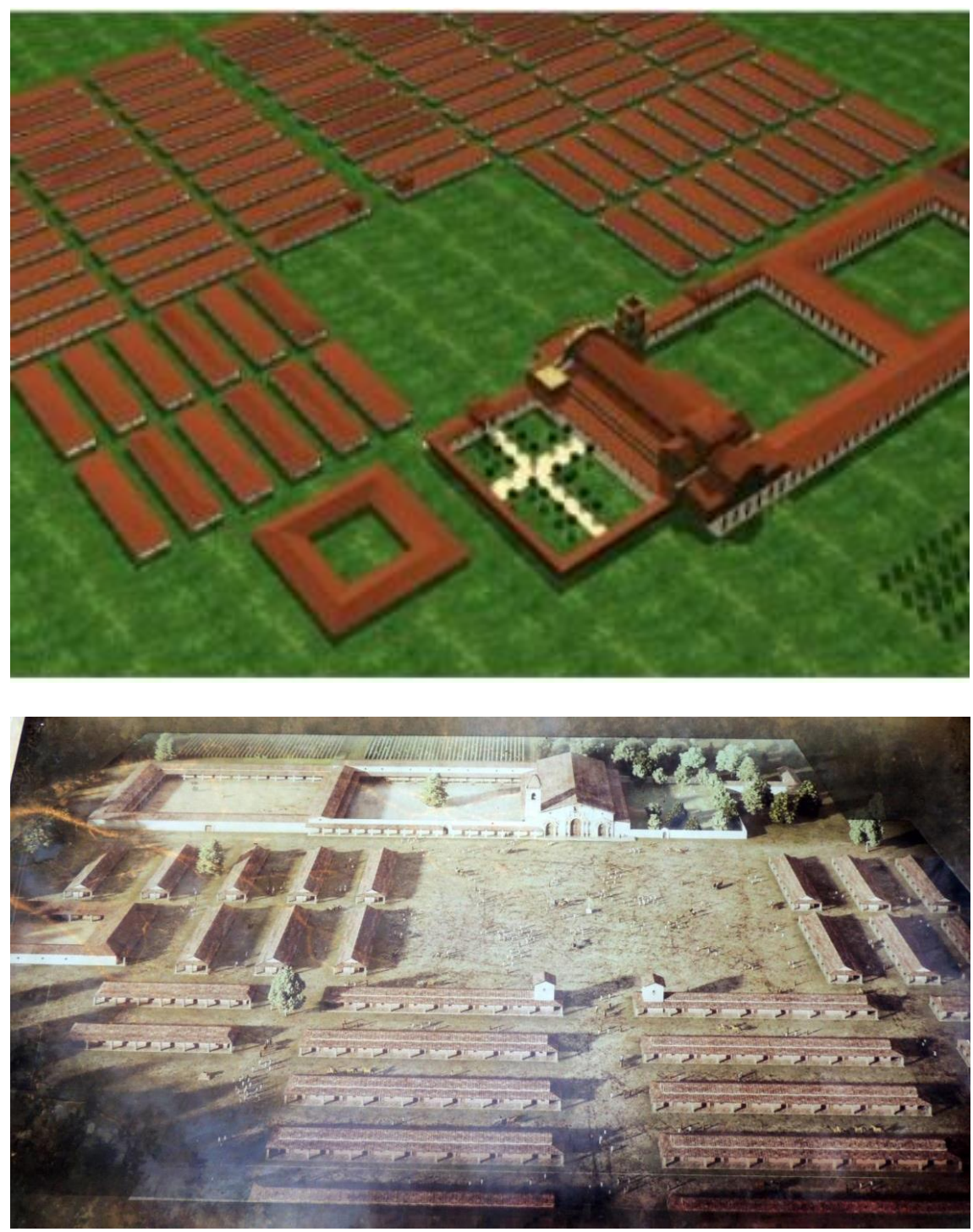

Figura 38. Reconstituições dos sítios históricos de São Miguel - Brasil (acima), e San Ignácio Miní - Argentina (abaixo).

Fonte: UNISINOS; IPHAN, 1990, CD-ROM e foto da autora. 
de programas de modelagem, não estão disponíveis no ambiente da Internet, o que faz com que seu alcance seja limitado. Se disponibilizadas em rede e, desse modo, compartilhadas tanto com pesquisadores para embasar diversos estudos e a produção de conhecimento, quanto com a comunidade leiga, tais informações seriam utilizadas para ampliar a compreensão sobre as raízes e origens culturais locais, entendendo, enfim, o presente através do passado. De modo a funcionar como meios para divulgar, fazer entender e contextualizar, por exemplo, a tipologia arquitetônica missioneira, os modos de vida e o cotidiano dentro de uma missão. Além disso, se houvessem reconstituições de todas as Reduções, seria possível analisar suas semelhanças e diferenças, traçando características construtivas e de implantação urbanística. Contudo, estes trabalhos exigem altos investimentos de tempo e dinheiro, o que pode ser a razão de não terem sido realizados.

Sobre a terceira categoria, os websites ${ }^{92}$ possuem dois níveis de abrangência: global e local. Em nível global, a UNESCO disponibiliza duas páginas contendo informações apenas sobre as Missões Jesuíticas que estão na Lista do Patrimônio da Humanidade (Figura 39, na próxima página). Seguindo como critério de organização o fato de terem sido inscritas em duas etapas, uma das páginas refere-se às Missões argentinas (San Ignácio Miní, Santa Ana, Nuestra Señora de Loreto, Santa Maria Mayor) e à brasileira (São Miguel), enquanto a outra página trata das Missões paraguaias (La Santísima Trinidad de Paraná e Jesús de Tavarangue). Ambas reúnem informações sobre história e implantação, e fotografias, além de disponibilizarem links para os relatórios de conservação e preservação.

\footnotetext{
${ }^{92}$ Cabe ressaltar que existe muito material disponível online, mas a maioria é proveniente de fontes não oficiais, como blogs pessoais de viagens. Os websites oficiais e, portanto, com informações confiáveis, encontrados através de buscas pelo termo "missões jesuíticas" nos idiomas espanhol, português e inglês.
} 


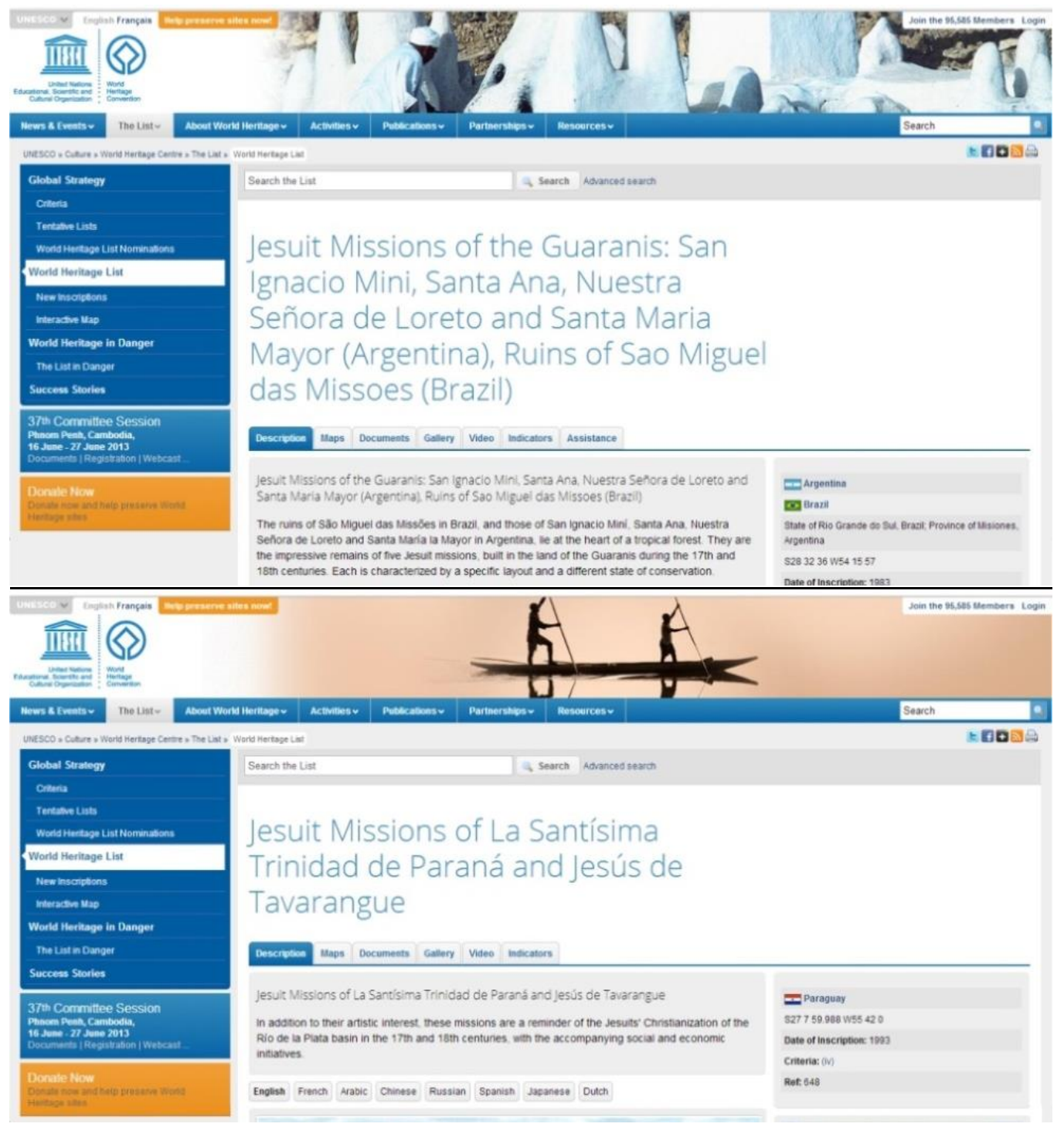

Figura 39. Divulgação online internacional: páginas da UNESCO que divulgam as Missões Jesuíticas inclusas na Lista do Patrimônio Mundial.

Fonte: http://whc.unesco.org/en/list/275 e http://whc.unesco.org/en/list/648, respectivamente. 
Por se tratar de página hospedada junto ao portal de um órgão internacional que divulga o patrimônio da humanidade, as informações sobre as Missões Jesuíticas nele contidas são organizadas de maneira padrão e seguindo um design específico da instituição, de forma que não possuem uma estética diferenciada e característica. Sendo uma vitrine das Missões para o mundo, esta página poderia conter dados multimídia que esclarecessem sobre a história desta região, sobre suas características sociais, econômicas, políticas e culturais no passado e na atualidade, de modo a ser um espaço de informação mais completo e instigador. Também poderia conter link para um local em que fossem reunidas informações sobre todas as Missões Jesuíticas, passado e presente, divulgando conhecimento e incentivando o turismo.

No Brasil (Figura 40, na próxima página), o IPHAN hospeda em seu portal uma página sobre São Miguel e as reduções argentinas (http://www.iphan.org.br/), contendo um resumo histórico, o atual estado de conservação e o início da atuação do IPHAN. Além disso, disponibiliza um arquivo com conteúdo básico sobre os remanescentes, o museu e algumas informações turísticas (http://www.iphan.gov.br/baixaFcd Anexo.do?id=276). Além do site do IPHAN, no Brasil ainda existe o portal da Rota das Missões (www.rotamissoes.com.br), onde se reúnem informações sobre as Missões (um breve histórico, um relato sobre a cultura guarani e a composição cultural do gaúcho), um guia de atrativos turísticos da região e outro sobre como chegar às Reduções. Estes portais divulgam principalmente o turismo na região, pecando no acesso às informações sobre a história e a cultura missioneiras.

No Paraguai (Figura 41, na página 177), o portal da Secretaria Nacional de Turismo SENATUR (http://www.senatur.gov.py/) apresenta material sobre as Missões Jesuíticas em três páginas relacionadas ao turismo. A primeira, intitulada Misiones Guarani Jesuíticas, promove não 

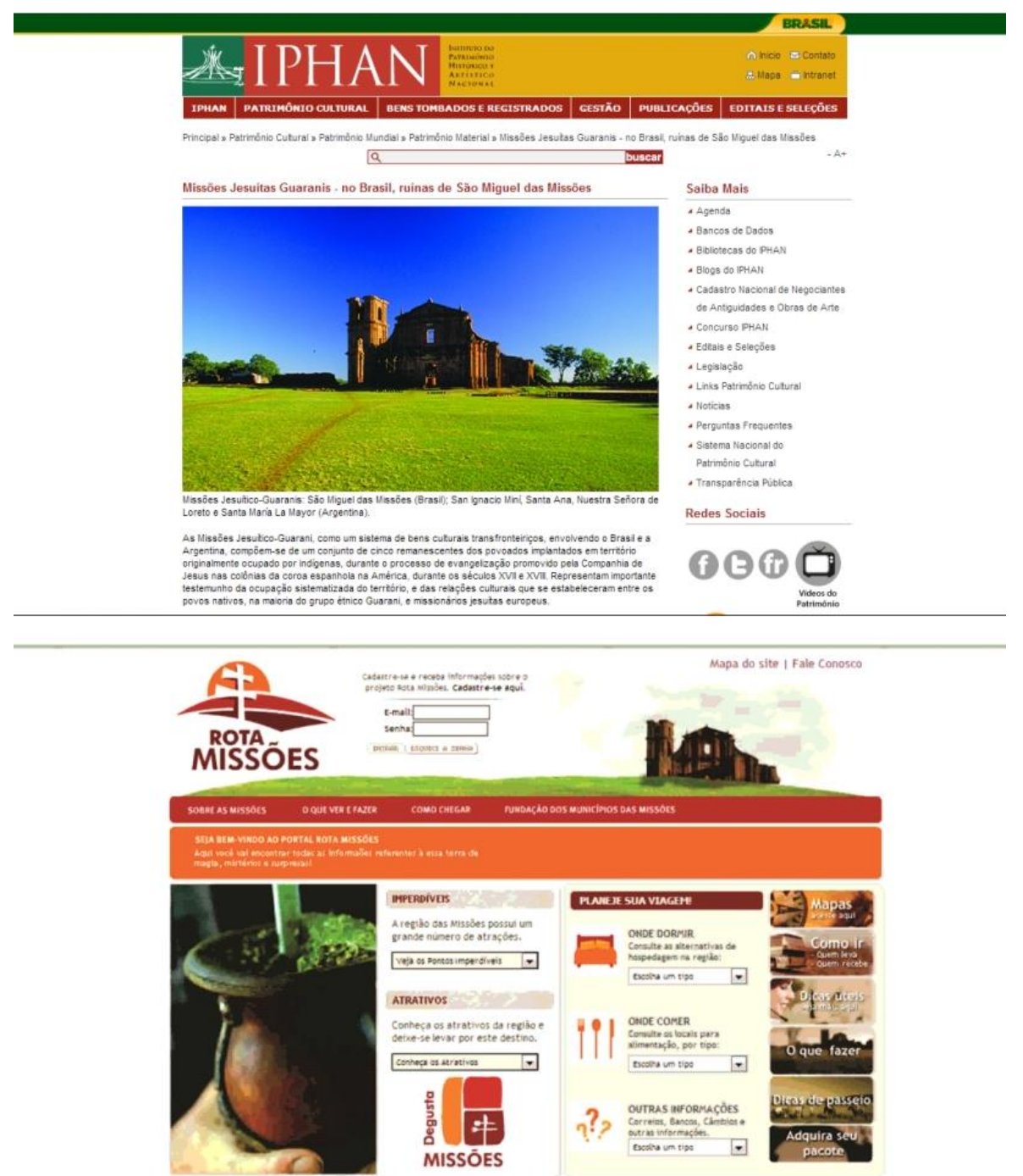

Figura 40. Divulgação online brasileira: Acima, página sobre as missões jesuíticas declaradas em nível mundial no site do IPHAN. Ao centro, site da Secretaria de Turismo da cidade de São Miguel. Abaixo, site da Rota das Missões. Fontes: http://portal.iphan.gov.br/; http://turismo.saomiguel-rs.com.br/; http://www.rotamissoes.com.br/, respectivamente. 


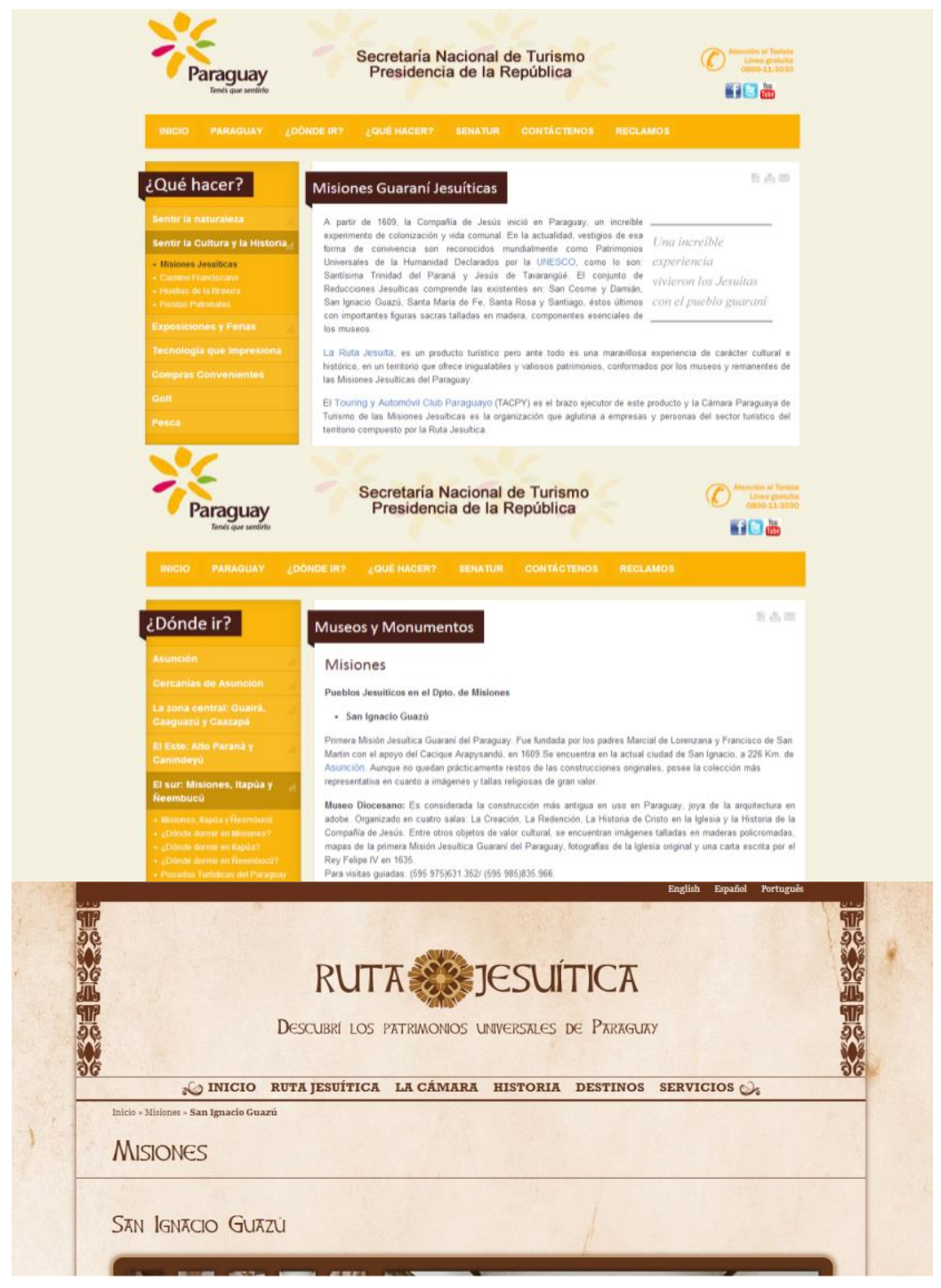

Figura 41. Divulgação online paraguaia: Acima, páginas do portal da SENATUR que contêm informações sobre as Missões Jesuíticas. Abaixo, portal Ruta Jesuítica.

Fonte: www.senatur.gov.py e rutajesuitica.com.py. 


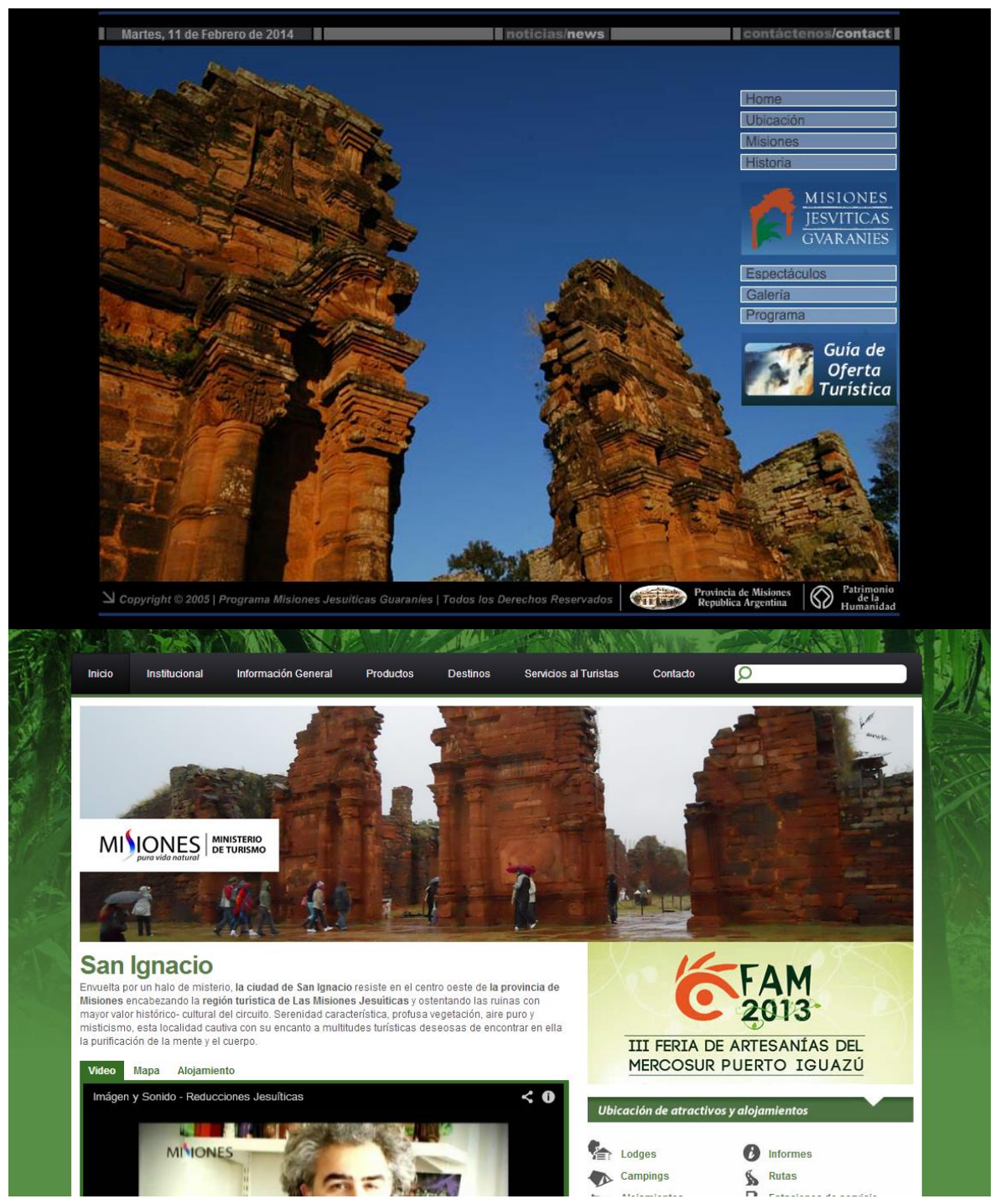

Figura 42. Divulgação online argentina. Acima, portal Misiones Jesuíticas Guarani. Abaixo, portal do Ministério do Turismo da Província de Misiones.

Fonte: http://www.misiones-jesuiticas.com.ar/ e http://www.turismo.misiones.gov.ar/sanignacio.php 
só o turismo aos sítios históricos, mas também as festividades que ocorrem nas cidades em que estes estão implantados. A segunda, relacionada aos estados paraguaios, trata da região que abrange Misiones, Itapúa y Ñeembucú, apresentando informações sobre a localização e os principais atrativos turísticos locais. E a terceira apresenta os Museos y Monumentos nacionais, trazendo informações sobre localização e contato dos diversos museus e monumentos históricos do Paraguai. Este site, por ser vinculado à Secretaria Nacional de Turismo, assim como os principais sites brasileiros, possui o caráter de divulgação turística nacional, não apresentando informações históricas e culturais mais relevantes.

Em relação às Missões Jesuíticas paraguaias também está online o portal Ruta Jesuítica: Descubrí los Patrimonios Universales de Paraguay (http://rutajesuitica.com.py/), que disponibiliza material em três idiomas: inglês, espanhol e português. Constitui um espaço online dedicado às atrações turísticas deste país, criado através de parceria entre a SENATUR e os governos dos Departamentos de Misiones, Itapúa e Alto Paraná, com apoio da UNESCO e do BID. Possui uma apresentação visual inspirada nas Missões Jesuíticas, diferente dos demais websites já analisados. Apresenta conteúdo organizado por departamento, indicando localização, artesanato, festas, celebrações religiosas e atrativos turísticos. Dentre estes, estão os povoados jesuíticos, cada qual com uma página específica, contendo informações sobre remanescentes móveis e imóveis presentes em cada cidade. Portanto, diante dos exemplos já citados, disponibiliza o conteúdo mais bem organizado, facilitando a aquisição de um conhecimento mínimo sobre o patrimônio missioneiro deste país.

Na Argentina (Figura 42, na página ao lado), o governo possui um portal específico sobre as Missões Jesuíticas Guaranis (http://www.misiones-jesuiticas.com.ar/) com informações sobre seis aspectos: 1. localização dos sítios históricos nacionais, quais estão abertos à visitação pública, 
quais os aeroportos disponíveis; 2. Fotografias dos sítios históricos; 3. textos sobre a história missioneira, contendo introdução, localização das Trinta Reduções e sua organização espacial; 4. Espetáculos de luz e som; e 5. apresentação do Programa Misiones Jesuíticas, responsável pela restauração, conservação e divulgação das Missões argentinas. Já o site da Província de Misiones (http://www.turismo.misiones.gov.ar/ sanignacio.php) também apresenta informações turísticas no portal destinada a San Ignácio Miní, mas está mais concentrado em divulgar os esforços nacionais de preservação do que o patrimônio em si.

Conclui-se que, embora no passado o Brasil tenha sido pioneiro na criação de uma plataforma online com informações sobre os Trinta Povos (Custódio, 2014), atualmente é o único dos três países analisados que não possui um ambiente online para divulgação sequer de suas Missões nacionais. Não existe um espaço virtual em que as Trinta Missões sejam divulgadas conjuntamente. Além disso, os poucos websites encontrados tratam apenas questões turísticas de Reduções isoladas ou dos grupos nacionais, havendo carência de plataformas online com o intuito de organizar e divulgar as informações sobre o conjunto histórico. Também não foram encontrados websites acadêmicos sobre o assunto.

Os websites existentes são poucos e, além disso, a maioria deles não possui uma identidade visual própria por serem hospedados pelos órgãos nacionais responsáveis por sua preservação. Dessa forma, as informações sobre as Missões Jesuíticas não se destacam em meio às demais páginas; o que poderia provocar uma ruptura entre as relações realizadas entre o patrimônio e sua representação virtual. Por seu caráter turístico em vez de histórico-acadêmico, cada um deles oferece somente informações básicas sobre a história e a cultura missioneiras. De modo que a educação patrimonial fica prejudicada e prevalece a necessidade de visitar fisicamente as Reduções Jesuíticas dos três países para a obtenção de informações mais detalhadas; o que afeta 
a valorização e a apropriação deste patrimônio, pois não é possível perceber a importância daquilo que não se conhece. Contudo, esta escassez de informações também ocorre no âmbito físico, pela pouca quantidade de material impresso disponível para o público: desde folhetos turísticos até livros. O que demonstra a grande burocracia em relação à concepção e ao financiamento deste material e é refletido na pouca acessibilidade a informações para o turista através de meios impressos.

O sociólogo e filósofo norte-americano Andrew Pickering (2002, p. 424, tradução nossa ${ }^{93}$ ) salienta que "[...] O problema fundamental de gestão, então, recai não sobre a construção e manipulação de bases de dados maiores, mas, primeiramente, sobre o design ardiloso do fluxo de informação [...]". De modo que é importante criar ambientes que reúnam o conhecimento sobre as Missões Jesuíticas e possibilitem e instiguem a comunicação entre os agentes. O que pode ser realizado, segundo o designer brasileiro Gilberto Alves Jr. (2005, p. 2), guiando-se através de duas principais perguntas:

1) Que tipo de dados nós vamos ter? E então fazer estratégias para adquirir estes dados, aproveitando todos os recursos que a internet dá, inclusive os usuários que frequentam o site.

2) Como vamos mostrar estes dados ao usuário? E então desenvolver programas para mostrar os dados, preferencialmente sem predefinir um comportamento para o usuário mas fazendo o software de forma que o usuário possa modificá-lo e receber somente a informação que ele quiser, do jeito que ele quiser.

\footnotetext{
${ }^{93}$ Do original em inglês: "[...] The fundamental problem of management, then, lay not in constructing and manipulating
} bigger databases, but, first, in the artful design of information flows [...]" (PICKERING, 2002, p. 424). 
Se os esforços de criação de conteúdo forem reunidos, poderia haver um aprofundamento destas informações e, consequentemente, uma maior sensibilização da população, vencendo os dois desafios apontados pelo médico norte-americano Slavo Milekic (2007): buscar espaços que sejam suportes para as interações entre os agentes do sistema e que reúnam informações cuja qualidade seja igual ou superior ao ambiente concreto que representam. Através de um processo de auxílio mútuo, as informações poderiam ser disponibilizadas em um único local nos idiomas dos países envolvidos e em inglês para atingir um maior público. Mesmo estando voltada à educação patrimonial, esta interface integrada dos sítios históricos também alavancaria o turismo.

A evolução das tecnologias digitais possibilita que os portais não apresentem apenas informações ao visitante, como vias de acesso, distâncias das principais cidades ou fotografias e textos (como é atualmente utilizada para as Missões Jesuíticas). Atualmente, é possível conectar órgãos de preservação, acadêmicos e comunidade para que o patrimônio cumpra todos seus objetivos: suporte de memória e identidade, que incentivam uma reflexão não somente sobre o passado, mas também sobre o presente e sobre o que as comunidade desejam para seu futuro. de modo que a possibilidade atual de utilizar diversas ferramentas multimídias (mapas, imagens aéreas, modelos tridimensionais, além de imagens, textos e vídeos) aumenta o entendimento do patrimônio por parte do visitante e, portanto, a efetividade da divulgação do conhecimento sobre ele. Além disso, aumenta sua curiosidade e o incentiva a visitar fisicamente o local. 
A seguir são apresentadas tecnologias digitais usadas em quatro exemplos de aplicações digitais ou híbridas que poderiam auxiliar os processos educativo e de colaboração envolvidos nas trocas de conhecimento relacionados às áreas da pesquisa, preservação e divulgação das Missões Jesuíticas de maneira integrada e de modo a realizar aquilo que foi indicado pelos próprios representantes dos países envolvidos com a preservação missioneira, ao final do "Programa de Capacitação para Conservação, Gestão e Desenvolvimento Sustentável das Missões Jesuíticas dos Guarani" (WORLD MONUMENTS FUND, 2004): integrar e centralizar os documentos e as informações; produzir conteúdo sobre o conjunto missioneiro que permita seu entendimento; e validar a preservação desse patrimônio único para a humanidade, as comunidades locais e glocais por seu caráter sistêmico.

Levantamento de informações e base de dados

Segue o exemplo de uma base de dados, criada no âmbito do projeto Critérios e metodologias para a realização de inventário do patrimônio cultural paulista, que permitirá reunir, organizar e disponibilizar à comunidade os acervos históricos. O projeto é continuação de uma longa jornada de pesquisa e desenvolvimento iniciada com o Projeto de Políticas Públicas Memória Virtual de São Carlos, realizado entre os anos de 2004 e 2008, e está voltado principalmente ao patrimônio das fazendas paulistas. A importância deste trabalho está 
relacionada ao estado precário destes acervos. De acordo com o coordenador do projeto, o engenheiro elétrico brasileiro José Carlos Maldonado (2004, p. 1) do Instituto de Ciências Matemáticas e de Computação da USP-São Carlos,

[...] Para o desenvolvimento do sistema, um pré-requisito essencial é a definição e a padronização da forma e dos acessos a essas informações históricas e culturais. A definição e padronização são realizadas por meio das normas e dos padrões da representação descritiva e temática, subárea da Ciência da Informação, que visa a descrever os documentos de forma a garantir a qualidade e a acessibilidade das informações disponibilizadas, bem como a integração de várias redes de informação tanto nacionais quanto internacionais. [...].

Com a realização desta primeira versão do sistema web, o maior ganho foi a integração entre o setor público, os professores e os estudantes de diversas áreas, como Ciências da Computação, Arquitetura, Ciências da Informação e Sociologia.

Em seguida, entre os anos de 2008 e 2012, foi realizado o projeto Patrimônio cultural rural paulista: espaço privilegiado para a pesquisa, ensino e turismo. De acordo com o coordenador, o arquiteto brasileiro Marcos Tognon (2008, p. 1) da Universidade Estadual de Campinas-UNICAMP, o objetivo principal da pesquisa foi o de "[...] disponibilizar instrumentos e metodologias de gestão, de conservação e de difusão para os responsáveis por esse patrimônio cultural rural, tanto os proprietários quanto as respectivas instâncias públicas pertinentes da área da cultura, da educação e do turismo". Durante esta pesquisa, foram aprimorados os métodos de levantamento de dados e o chamado padrão de descrição da informação, cujo desenvolvimento se iniciou no projeto anterior.

O projeto atual tem vigência entre 2012 e 2014 e é intitulado Critérios e metodologias para a realização de inventário do patrimônio cultural paulista. Segundo a coordenadora do projeto, a 
cientista da informação brasileira Luzia Costa $(2012$, p. 1) da Universidade Federal de São CarlosUFSCar, "[...] o foco metodológico do projeto [...] reside no aprimoramento de um Padrão de Descrição de Informação (PDI), aplicável a todo e qualquer tipo de bem cultural, seja imaterial, material, bibliográfico, arquivístico, museológico, arqueológico ou natural. [...]". Nesse sentido existem duas linhas de ação dentro da pesquisa. A primeira se concentra em metodologias para o levantamento de dados e seu cadastro no sistema. Sua principal contribuição para o caso das Missões Jesuíticas poderá estar na ênfase da necessidade de registro do patrimônio imaterial, cuja volatilidade enfatiza a urgência de ações neste sentido e cujo levantamento, conforme mencionado, foi iniciado no ano de 1987, de acordo com Custódio (2014).

Já a segunda linha de ação está focada na continuidade de desenvolvimento da interface online. O Memória Virtual é um sistema web para reunir, catalogar e divulgar acervos históricos, que foi desenvolvido como software livre e está disponível para utilização por qualquer instituição interessada. Projetado por uma equipe multidisciplinar, terá a capacidade de cadastrar os mais diversos tipos de acervos históricos: patrimônio material móvel e imóvel, e também patrimônio imaterial e natural. Possibilitará a inclusão de imagens e vídeos relacionados aos bens cadastrados categorias de descritores são apresentadas na janela de cadastro de bem patrimonial (na Figura 43, na próxima página).

De acordo com os cientistas da computação brasileiros Elisa Nakagawa e Thiago Bianchi(2013), coordenadores da equipe de programação, o sistema foi pensado para abrigar várias instituições com seus acervos e um amplo número de entradas de dados para descrevê-los, sem a necessidade de se criar uma cópia para cada uma delas. Sua principal diretriz é organizar as informações de um determinado acervo histórico e disponibilizá-las à população. Também é possível cadastrar acervos e não disponibilizá-los para consulta, de acordo com o desejo da 

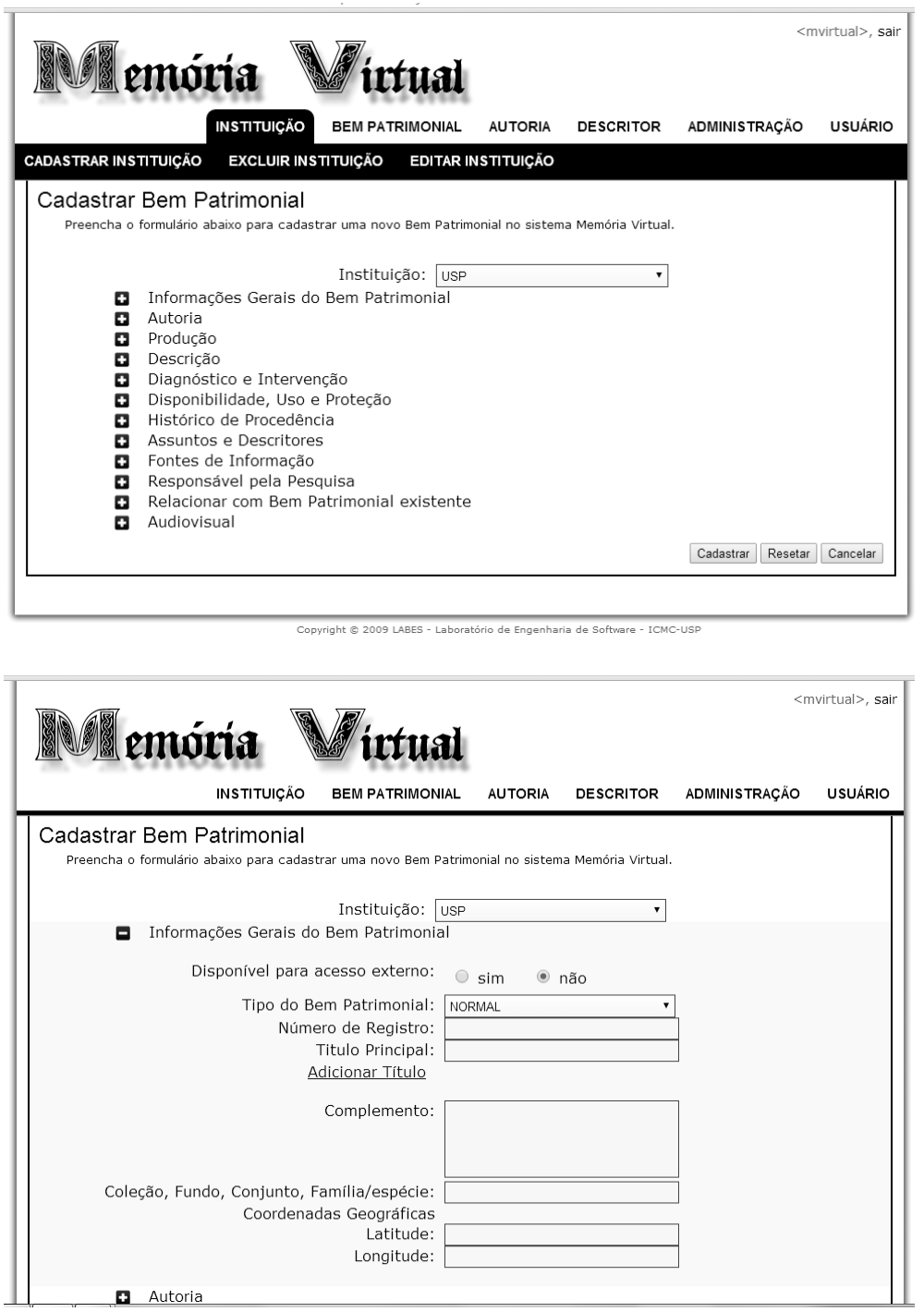

Figura 43. Interface da versão teste do sistema web em desenvolvimento intitulado Memória Virtual: tela de cadastro de bens patrimoniais resumida (acima) e estendida (abaixo).

Fonte: PrintScreen da autora. 
instituição. Durante a concepção do sistema, preocupou-se com o cadastro de usuários, que é realizado apenas através de convite e com níveis de atribuições, de modo que as alterações e inserções de informações são seguras. O profissional é cadastrado para ter direito a inserir e alterar conteúdo, enquanto o usuário da comunidade pode realizar buscas e acessar o material disponível.

O sistema ainda permitirá hierarquizar o patrimônio, de modo que se pode cadastrar, por exemplo, uma xícara dentro do conjunto de chá, que está na sala da sede de uma fazenda. Por ser um sistema em desenvolvimento, algumas funções são previstas, mas ainda não foram desenvolvidas, como o relatório de acervo.

No caso das Missões Jesuíticas, esta é uma proposta interessante, que funcionaria como uma central de integração entre as instituições com a finalidade de reunir informações sobre os acervos nacionais, móveis, imóveis, naturais e imateriais; com a finalidade de posterior disponibilização à população, como foi realizado no projeto de informatização das Missões Jesuíticas do Brasil, na década de 1990. Contudo, as bases de dados não possibilitam a interação entre os agentes e precisariam ser complementadas com ferramentas com este propósito. A contribuição deste projeto para o caso das Missões Jesuíticas está relacionada às metodologias de levantamento de informações e ao desenvolvimento de uma base de dados cujos descritores oferecem a possiblidade de incluir todo o tipo de patrimônio. Cabe ressaltar que este é apenas um dos diversos projetos que são realizados ao redor do mundo com esta preocupação ${ }^{94}$.

\footnotetext{
${ }^{94}$ Uma proposta similar é realizada pelo Programa Patrimônio em Rede, coordenado pela Curadoria do Acervo dos Palácios do Estado de São Paulo, que prevê a catalogação do patrimônio histórico presente nos gabinetes de órgãos públicos, constituído de mobiliário e obras de arte, entre outros. Participam do programa Secretarias e Unidades vinculadas, cujos funcionários são capacitados para identificar o patrimônio, levantá-lo e realizar o preenchimento da
} 


BaroqueArt
A data collection of Hispanic Baroque painters and
paintings from 1550 to 1850.

Creators

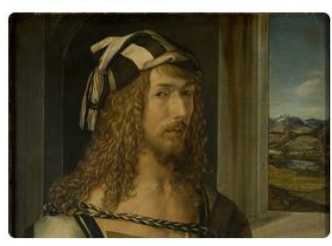

View biographical information, such as date of birth and death, place of birth and relations to other artists.
Artworks

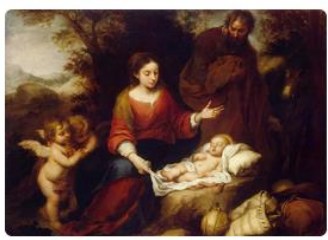

View information on artworks, such as thei original location, their current location and its relation to the creator.

View Artworks »
Series

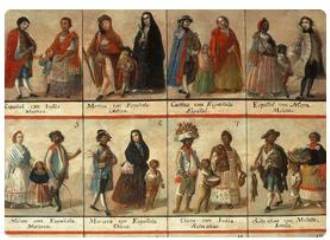

View a series, including the works belonging to a group of artworks and the different pieces in one series.

View Series »

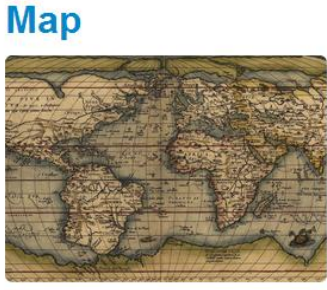

The map view allows a visualization of the paintings in both spacial and temporal settings.

\section{View Map »}

Figura 44. Projeto O Hispânico Barroco.

Fonte: http://baroqueart.cultureplex.ca/

ficha catalográfica dos bens em sua unidade. Já em execução, esta plataforma demonstra a viabilidade do uso dos profissionais dos órgãos responsável para a alimentação do sistema (SÁ NETO; GUERRA, 2013). 
O grupo de pesquisa CulturePlex - Cultural Complexity and Digital Humanities Lab é coordenado pelo Prof. Dr. Juan Luís Suárez e desenvolve diversos projetos voltados ao patrimônio visto sob o viés da Complexidade, dentre eles o intitulado O Barroco Hispânico: Complexidade na primeira cultura Atlântica (The Hispanic Baroque: Complexity in the first Atlantic culture - Figura 44, na página ao lado). Envolve pesquisadores de diferentes países das áreas de Humanidades Digitais, Ciência da Computação e História da Arte e é financiado pelo Conselho de Pesquisa em Ciências Sociais e Humanidades do Canadá. O grupo Cultureplex está ligado à linha de pesquisa intitulada "Trabalhando a Teoria da Complexidade e uso de Base de dados", cujos objetivos são:

o desenvolvimento de uma base de dados que relacione os objetos do Barroco, que permita análise estatística, modelos de sistemas complexos e tendências evolucionárias [...] e análise de grafos

o avanço da aplicação e o desenvolvimento de conceitos da Teoria da Complexidade e a pesquisa baseada em sistemas complexos na área de Humanidades

o treinamento de estudantes de graduação e pesquisadores em métodos quantitativos e no uso de ferramentas de pesquisa de sistemas complexos (CULTUREPLEX, s.d., s.p., tradução nossa ${ }^{95}$ ).

\footnotetext{
${ }^{95}$ Do original em inglês: "the development of a database that relates to Baroque objects, which allows statistical analysis, models of complex systems and evolutionary tendencies [...] and the analysis of graphs

the advancement of the application and development of concepts of the theory of complexity and the research based on complex systems in the area of Humanities

the training of graduate students and researchers in quantitative methods and the use of research tools of complex systems" (CULTUREPLEX, s.d., s.p.).
} 
O estudo da Complexidade em relação ao patrimônio não é um fato isolado desta pesquisa, ocorre em projetos ao redor do mundo. O que demonstra sua atualidade e o interesse do meio acadêmico em produzir ferramentas pensadas especificamente para atender a suas necessidades.

Este sistema é baseado em Web Semântica, que foi idealizada por Tim Berners-Lee (o mesmo pesquisador que trabalhou na criação da ferramenta que deu origem à World Wide Web - W3C) como ferramenta potencial para aprimorar os métodos de inserção e busca de material na Internet (CAMPBELL; FAST, 2004; HOLLINK et al, 2007; SCHREIBER et al, 2008; BURKE, 2009; GARCÍA-CRESPO et al, 2010). Segundo a W3C (s.d., s.p., tradução nossa ${ }^{96}$ ), a Web Semântica é "uma rede de dados - de dados e títulos, e números de peças, e propriedades químicas, e quaisquer outros dados que se possa conceber". De acordo com o engenheiro de computação coreano Hanmin Jung et al (2009, p. 1, tradução nossa ${ }^{97}$ ), ela tem o objetivo de "proporcionar serviços de conexão, fusão e análise de informações em pesquisas acadêmicas a fim de que os cientistas efetivamente obtenham informações. A fim de ajudar os cientistas a acessar informações relevantes". Dessa forma, pode-se visualizar a Web Semântica como aquilo que Flusser (2008, p. 106) chama de estratégia: a “[...] arte de redistribuir 'dados' em jogos com parceiros", pois a função primordial da Web Semântica é justamente essa: a reorganização mais eficaz da enxurrada de informações que configura o atual estágio da Internet.

De forma simplificada, pode-se dizer que a Web Semântica busca formular uma linguagem legível para os computadores, com a finalidade de que eles possam auxiliar o usuário durante a

\footnotetext{
${ }^{96}$ Do original em inglês: "[...] a Web of data — of dates and titles and part numbers and chemical properties and any other data one might conceive of" (W3C, s.d., s.p.).

${ }^{97}$ Do original em inglês: "[...] to provide connection, fusion, and analysis services on academic research information to enable scientists to effectively obtain information. In order to help scientists to access relevant information" (JUNG et al, 2009, p. 1).
} 
busca por informações, retornando resultados mais relevantes. Dessa forma, os dados cadastrados em um sistema tornam-se elementos de uma rede semântica ao serem associados a determinados conceitos durante sua inclusão. Lembrando que a semântica "refere-se ao estudo do significado, em todos os sentidos do termo" (wikipedia), de maneira que, através dessa tecnologia, a máquina entende o significado da chave de pesquisa e retorna sinônimos e conceitos correlatos em diversas línguas referentes ao conceito buscado e não somente ao termo específico digitado pelo usuário.

A chave da Web Semântica é a caracterização de um arquivo através de seu conceito e das relações que mantêm com os demais, de tal forma que sua ideia central é entendida pelo computador. Essa funcionalidade é realizada através de ontologias (como o exemplo da Figura 45, na próxima página), que

\begin{abstract}
foram desenvolvidas no campo da Inteligência Artificial para facilitar o compartilhamento e o reuso do conhecimento (Fensel et al, 2001). As ontologias fornecem um vocabulário comum para um domínio e definem, com diferentes níveis de formalidade, o significado dos termos e as relações entre eles. O conhecimento em ontologias é formalizado usando cinco tipos de componentes: classes, relações, funções, axiomas e instâncias (Gruber, 1993) (GARCÍA-CRESPO, 2010, p. 1, tradução nossa ${ }^{98}$ ).
\end{abstract}

De acordo com Suárez et al (2013, p. 3), este banco de dados, formulado com esta linguagem, permite, por exemplo, que sejam gerados gráficos que representam diversos aspectos

${ }^{98}$ Do original em inglês: "[...] were developed in the field of Artificial Intelligence to facilitate knowledge sharing and reuse (Fensel et al., 2001). Ontologies provide a common vocabulary for a domain and define, with different levels of formality, the meaning of the terms and the relations between them. Knowledge in ontologies is mainly formalized using five kinds of components: classes, relations, functions, axioms and instances (Gruber, 1993)" (GARCÍA-CRESPO, 2010, p. 1). 


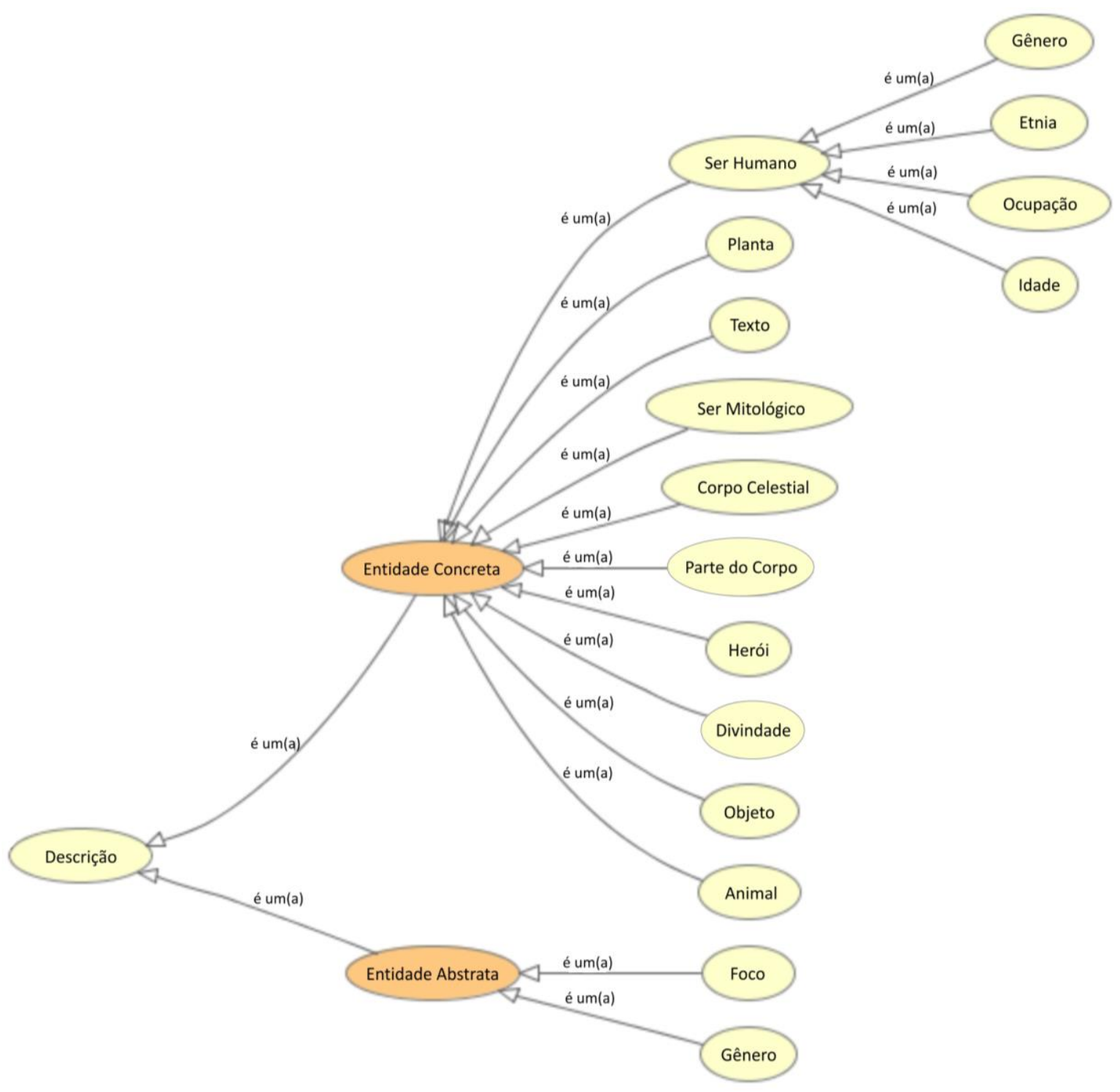

Figura 45. Pequena parte da ontologia do projeto O Hispânico Barroco. Fonte: CULTUREPLEX, 2011, p. 2, tradução e resumo nossos.

192 
das obras de arte, de acordo com os diversos descritores utilizados. Esta base de dados também pode gerar um mapa contendo a localização das obras de arte catalogadas. No caso das Missões Jesuíticas, poderia ser produzido um mapa regional, apontando remanescentes móveis e imóveis, além dos principais centros de produção de conhecimento desta área e onde se encontram.

A potencialidade do uso dessa tecnologia a favor do patrimônio cultural é afirmada pelo cientista da computação húngaro Barnabás Szász et al (s.d., p. 2, tradução nossa ${ }^{99}$ ):

\begin{abstract}
Um dos campos de aplicações que será beneficiado pelos avanços recentes nas Tecnologias de Web Semântica é a área da Gestão do Conteúdo do Patrimônio Cultural. Esse campo envolve o desenvolvimento de aplicações para a eficiência do processamento, armazenamento, recuperação e exploração dos materiais acerca do patrimônio cultural.
\end{abstract}

Em relação apenas a aplicativos mencionados no próprio portal da $\mathrm{W} 3 \mathrm{C}$ e que abrangem a área do patrimônio podem ser citados: Astúrias, de Portugal (BERRUETA; POLO, 2007); Patrimônio cultural de Cantabria, da Espanha (HERNÁNDEZ, 2007); CRUZAR, da Espanha (FERNÁNDEZ; CAMPOS, 2008); e Aquaring, da Espanha (RODRÍGUEZ, 2009).

A Web Semântica não implica em diferenciação estética (Figura 46, na próxima página), pois sua atuação está na linguagem de programação, que não é visível para o usuário. Entre os benefícios do uso da Web Semântica para as Missões Jesuíticas destacam-se dois. O primeiro refere-se ao próprio conceito de semântica, que, segundo o matemático norte-americano Norbert Wiener (1950, p. 78) que "se relaciona com o significado" do termo. Como exemplificado nos

\footnotetext{
${ }^{99}$ Do original em inglês: "One of the fields of applications which will benefit from the recent advances in Semantic Web Technologies is the area of Cultural Heritage Content Management. This field involves the development of applications for the efficient processing, storage, retrieval and exploitation of cultural heritage materials" (SZÁSZ et al, s.d., p. 2).
} 

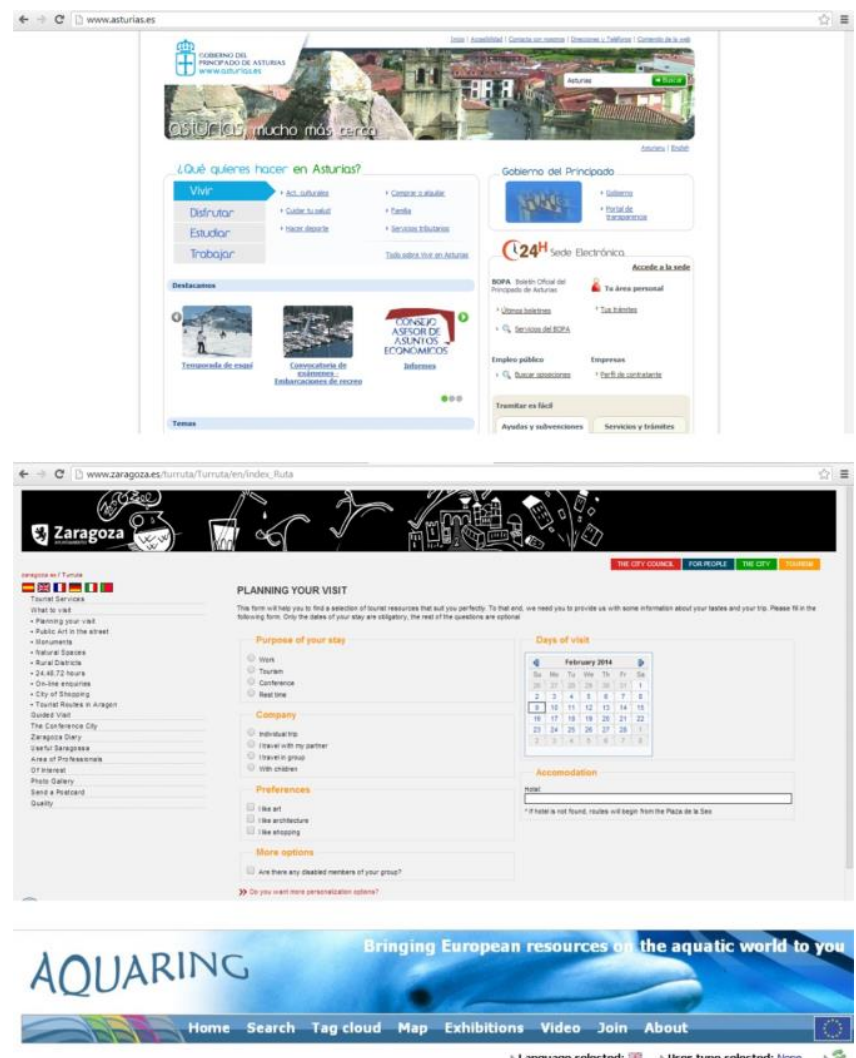

Select a topic General Species, Land, Habitats. Fisting areas. Vessels Education

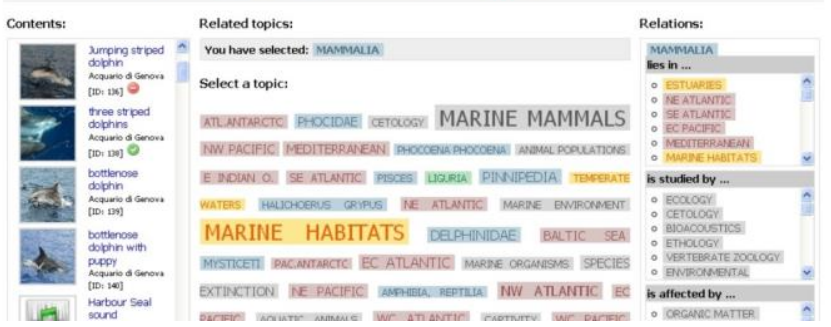

Figura 46. Exemplos de portais que utilizam a Web Semântica como linguagem.

Fonte: www.asturias.es, www.zaragoza.es/turruta/Turruta/index_Ruta e http://www.aquaringweb.eu/, respectivamente. 
projetos Aquatic Sciences (RODRÍGUEZ, 2009) e Asturias (BERRUETA; POLO, 2007), o uso da web semântica permite a aproximação dos termos técnicos e da linguagem popular, assim como entre diversas línguas, já que a pesquisa é realiza sobre o conceito da palavra digitada e não sobre ela. $\mathrm{O}$ que teria especial utilidade no caso dos indígenas, pois esta população poderia alimentar o banco e dados com sua cultura expressa em guarani. Através do registro deste patrimônio imaterial, evitar-se-ia a perda de informações tão importantes e insubstituíveis, que já vêm sendo esquecidas ao longo dos séculos. Dando voz à população sucessora dos habitantes missioneiros, negligenciada até os dias atuais, é possível entender de maneira mais completa os fatos históricos e sua contribuição para uma melhor inserção cultural local.

A tecnologia digital abriria o horizonte para a catalogação e a pesquisa em línguas indígenas através de termos de qualquer outro idioma. Além disso, possibilitaria buscas significativas relacionadas às Missões Jesuíticas, que retornariam resultados nas principais línguas em que a informação sobre as Missões encontra-se dispersa: espanhol, português e inglês. Fato que viria ao encontro previsão de que "O próximo passo lógico seria, não mais traduzir, mas superar as línguas através de uma consciência cósmica geral [...]" (MCLUHAN, 1979 [1964], p. 99). O mundo vivenciaria uma globalização do conhecimento, não somente em relação ao acesso, mas também à possibilidade de entendimento do que é produzido e oferecido através desta abstração dos idiomas, que, segundo o administrador Wagner Toscano (2003, p. 9) “consiste em desenvolver um modelo simplificado do mundo real, em que são descritos apenas os objetos e relações relevantes para a resolução do problema. Esse modelo abstrato resultante é chamado de conceitualização". 
Já o segundo benefício da Web Semântica para as Missões Jesuíticas refere-se à possibilidade descrita por Laura Hollink et al (2007, p. 195, tradução nossa ${ }^{100}$ ): "possibilita uma recuperação de informação mais e mais sofisticada. Usando ontologias ou tesauros, podemos agora combinar documentos a consultas baseadas em similaridades semânticas, mesmo se não houver relação textual entre a consulta e o comentário". Segundo o cientista da computação Guus Schreiber (2008, p. 243, tradução nossa ${ }^{101}$ ), "as novas Web Semântica e tecnologias de apresentação podem ser implantadas para proporcionar uma indexação e um suporte a buscas melhores dentro de grandes coleções virtuais de recursos do patrimônio cultural".

Um projeto interessante que utiliza a Web Semântica é o de Cantabria, na Espanha. Segundo a espanhola Francisca Hernández (2007, p. 1, tradução nossa ${ }^{102}$ ),

A informação que representa atualmente os onze patrimônios está dispersa, heterogênea, fragmentada e em vários estágios de formalização e digitalização. Por exemplo, alguns existem no governo oficial, outros em livros publicados e em exposições, muitos estão digitalizados, e alguns estão organizados em bases de dados. Essa situação dificulta o acesso amplo às informações, causa sérios problemas de integração, e torna a exploração da informação na Web custosa e

${ }^{100}$ Do original em inglês: "[...] enables more and more sophisticated information retrieval. Using ontologies or thesauri, we can now match documents to queries based on semantic similarity, even if there is no textual match between the query and the annotation" (HOLLINK et al, 2007, p. 195).

${ }^{101}$ Do original em inglês: "[...] novel SemanticWeb and presentation technologies can be deployed to provide better indexing and search support within large virtual collections of cultural-heritage resources. [...]" (SCHREIBER, 2008, p. 243).

${ }^{102}$ Do original em inglês: "The information currently representing the eleven heritages is dispersed, heterogeneous, fragmented and in varying stages of formalization and digitization. E.g. some exist in official government documents, others in published books and in expositions, many are digitized, and some are organized in databases. This situation hinders wide access to the information, causes serious integration problems, and makes exploitation of the information on the Web costly and tedious. Moreover, by its nature, cultural heritage is a domain with very dense interrelations within and between different heritages, which in the current situation are impossible to exploit" (HERNÁNDEZ, 2007, p. 1). 
tediosa. Além disso, por sua natureza, o patrimônio cultural é um domínio com inter-relações muito densas dentro de e entre diferentes patrimônios, que são impossíveis de serem exploradas na situação atual.

O mesmo cenário se desenha em relação às Missões Jesuíticas, em que o patrimônio remanescente e as informações encontram-se dispersos pelos países. Essa tecnologia poderia ser utilizada para buscas mais avançadas por bancos de dados e portais hospedados pelos três países e com mais resultados fornecidos em diversos idiomas (como espanhol, português, inglês e guarani) e contendo termos coloquiais e técnicos. Uma rede de conceitos e não de palavras retornará resultados mais consistentes. Embora ainda esteja em desenvolvimento, a Web Semântica é uma promessa não somente para a área do patrimônio, mas para a divulgação da informação em todas as áreas do conhecimento. "A ascensão do XML, juntamente com as iniciativas do Consórcio da WorldWideWeb para criar uma 'Web Semântica', sugerem que um novo mundo de informação baseada em rede estende-se diante de nós. Nesse novo mundo, a informação será entendida pelas máquinas [...]" (CAMPBELL; FAST, 2004, p. 383, tradução nossa ${ }^{103}$ ), as pesquisas serão maximizadas e a disseminação da informação será facilitada.

\section{Alfabetização tecnológica}

A Sociedade do Conhecimento que se configura em torno da transmissão digital, gera novas oportunidades para o uso e a difusão da informação. Já não

\footnotetext{
${ }^{103}$ Do original em inglês: "The rise of XML, along with the initiatives of the WorldWideWeb Consortium to create a "Semantic Web", suggests that a new world of Web-based information lies before us. In that new world, information will be machine understandable [...]" (CAMPBELL; FAST, 2004, p. 383).
} 
são uns poucos que comunicam a informação para milhões, mas são milhões que comunicam a outros milhões de pessoas a informação, no que se está chamando também de "sociedade relacional", fundamentalmente pelas infinitas oportunidades de intercâmbio e comunicação que gera (JUNTAEX; AUPEX, 2004d, p. 10, tradução nossa ${ }^{104}$ ).

\section{Neste contexto, foi iniciado em 1999 o projeto Plan de Alfabetización Tecnológica y Software}

Libre de Extremadura ${ }^{105}$, em uma parceria entre a Junta de Extremadura, a Associação Regional de Universidades Populares de Extremadura - Aupex e os Municípios, consistindo na implantação de Novos Centros do Conhecimento ${ }^{106}$ (NCC) - espaços públicos equipados com Internet banda larga gratuita $^{107}$, computadores, impressora, scanner, webcam e máquina fotográfica digital, utilizados com o auxílio de dois técnicos especializados - e na construção de uma interface virtual (baseada no software livre GnuLinEx), que contém sete espaços básicos: web labores, genealogia em rede, sinos em rede, rota gastronômica, ofícios perdidos, la picot e álbum fotográfico. Também estão disponíveis outros projetos, como periódicos, rádio e televisão. Os NCC oferecem cursos e apostilas de capacitação básica - disponibilizados também online - que baseiam a aprendizagem da tecnologia digital em aspectos do cotidiano da população.

\footnotetext{
${ }^{104}$ Do original em espanhol: "La Sociedad del Conocimiento que se configura en torno a la transmisión digital, genera nuevas oportunidades para el uso y difusión de la información. Ya no son unos pocos los que comunican la información a millones, sino millones los que comunican a otros millones de personas la información, en lo que se está dando en llamar también la "sociedad relacional", fundamentalmente por las infinitas oportunidades de intercambio y comunicación que genera" (JUNTAEX; AUPEX, 2004d, p. 10).
}

105 “Capacitar na alfabetização tecnológica [ou inclusão digital], não significa só que se adquira a formação básica no uso das tecnologias de informação e comunicação, significa também facilitar a compreensão da realidade na qual se desenvolvem os cidadãos e cidadãs. Em suma: tomar consciência, mudar atitudes, refletir coletivamente sobre o futuro, questioná-lo, oferecer alternativas e saber interpretar a realidade para mudá-la" (JUNTAEX; AUPEX, 2004d, p. 18 , tradução nossa).

${ }^{106}$ De acordo com os engenheiros espanhóis David Jacovkis e Wouter Tebbens (2007), no ano de 2007, havia 45 NCC.

${ }^{107}$ Fornecida pelo governo, que entendeu que a lei da oferta e procura nessa área da telecomunicação resultaria em uma concentração do serviço de Internet apenas nas áreas urbanas (JACOVKIS; TEBBENS, 2007,s.p.). 
Apesar de ser um projeto antigo, com quatorze anos, ainda está em curso e é referência em sua atuação como propulsor de inclusão digital e em seus resultados em relação à adesão popular. O projeto possui atualmente quarenta e cinco espaços físicos de difusão do conhecimento, distribuídos pela região. Levando estes conceitos para o caso das Missões Jesuíticas, poderiam ser realizados eventos de promoção da interface criada para seu entendimento e uso pela população.

Além do trabalho de inclusão digital, o projeto dedica uma atenção especial aos idosos que, segundo Jae Eun Chung et al (2010), não se sentem aptos a utilizar a Internet, por um preconceito em tentar utilizá-la, já que a maioria não teve dificuldades. Estes são personagens importantes para o patrimônio de uma sociedade por deterem o conhecimento sobre o passado, a memória de grupos sociais, e por isso sua utilização das mídias digitais deve ser incentivada. Dessa forma, no contexto da preservação do patrimônio cultural, este projeto é sensível a questões ressaltadas pelo historiador inglês Bill Schwarz (1992, p. 70), que envolvem a história oral, as memórias e esperanças de pessoas comuns e as relações sociais da produção de conhecimento histórico. De modo que os projetos online que o Plano de Alfabetização Tecnológica desenvolve funcionam como poderosos instrumentos para a dinamização de cidadãos e localidades (JUNTAEX; AUPEX, 2004b, p. 7), proporcionando uma transformação pessoal e coletiva.

Merece especial menção o item intitulado álbum fotográfico (Figura 47, na próxima página), que se mostrou uma importante ferramenta para resgatar e preservar a memória popular. Nele são reunidas imagens antigas de pessoas; fotografias de eventos como romarias, aniversários, festas; imagens da cidade e das atividades nela realizadas; viagens; todas trazidas pelos participantes e que auxiliam no entendimento do cotidiano e da história desta região. Totalizando 6.000 fotografias até o ano de 2004, que constituem "Pequenos tesouros acumulados com 


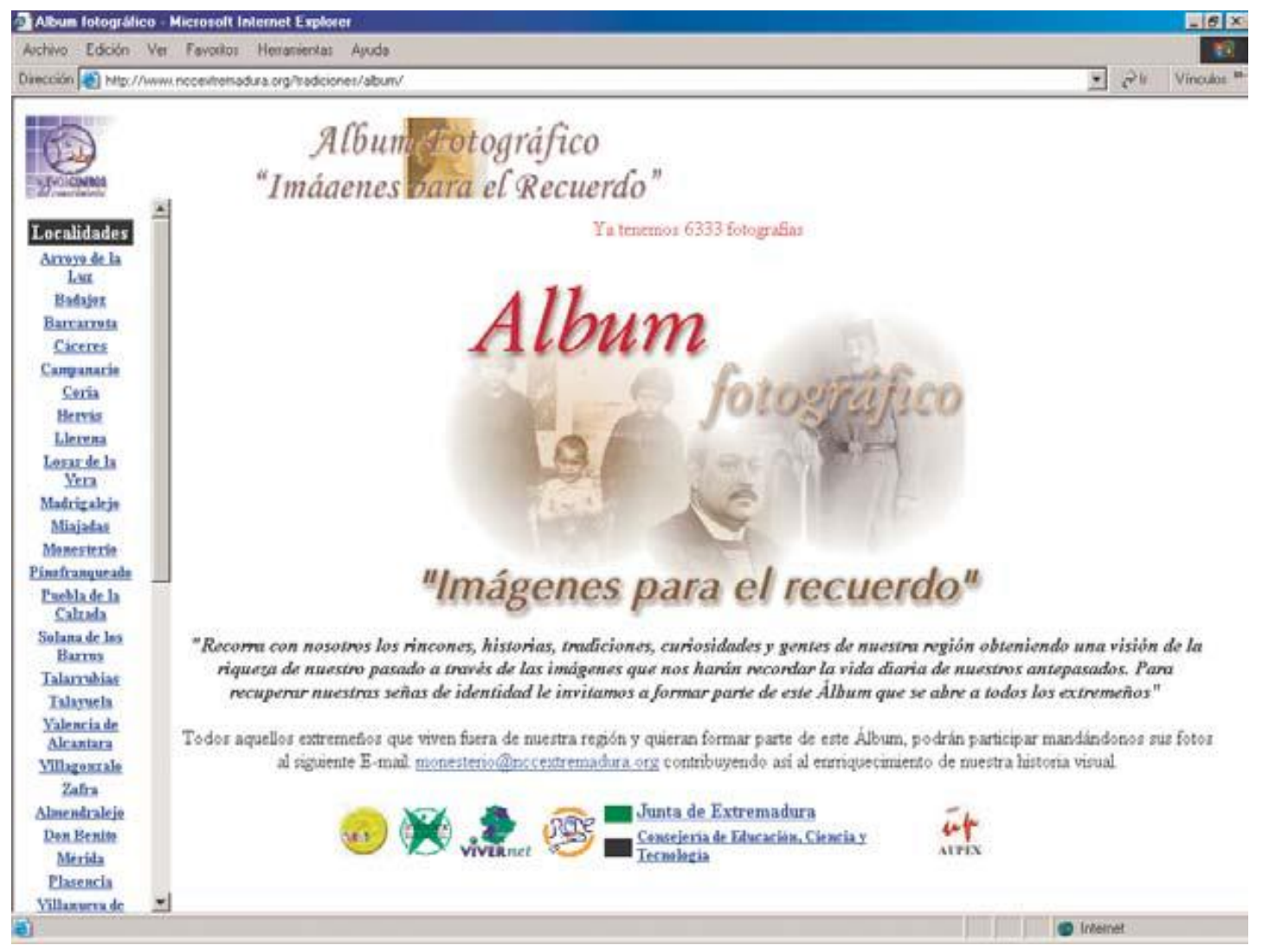

Figura 47. Página inicial do Álbum Fotográfico: imágenes para el recuerdo.

Fonte: JUNTAEX; AUPEX, 2004c, p. 28. 
carinho em caixas para uma posteridade incerta" (JUNTAEX; AUPEX, 2004a, p. 9, tradução nossa ${ }^{108}$ ), que são resgatadas por projetos como este e que fazem emergir nos participantes e na comunidade um sentimento de pertencimento que reforça a identidade cultural deste lugar.

Para viabilizar a realização destas atividades, os desenvolvedores consideraram o acesso aos equipamentos e programas adequados e a necessidade de promover a competência operacional nos participantes, fatores essenciais segundo Menezes (2007, p. 62). Com este objetivo, foram disponibilizados cartilhas de inserção digital e centros de alfabetização tecnológica que buscam ser

[...] espaços públicos, de acesso livre e democrático à Rede, dotados de equipamentos de informática suficientes para que cidadãos e organizações sociais, econômicas e culturais conheçam, pratiquem e experimentem as oportunidades que as Tecnologias estão gerando e podem gerar na região (JUNTAEX; AUPEX, 2004d, p. 6, tradução nossa ${ }^{109}$ ).

A análise deste projeto é importante para a formulação de um olhar diferenciado sobre a preservação e divulgação das Missões Jesuíticas porque se importa com algumas atividades consideradas importantes para o pleno desenvolvimento das Missões em relação à pesquisa, preservação e divulgação e que, segundo o entendimento desta pesquisa, devem ser direcionadas aos órgãos responsáveis e à população:

${ }^{108}$ Do original em espanhol: "Pequeños tesoros acumulados con cariño en cajas para una posteridad incierta" (JUNTAEX; AUPEX, 2004a, p. 9).

${ }^{109}$ Do original em espanhol: “[...] espacios públicos, de acceso libre y democrático a la Red, dotados de equipamiento informático suficiente para que la ciudadanía y las organizaciones sociales, económicas y culturales conozcan, practiquen y experimenten con las oportunidades que las Tecnologías están generando y pueden llegar a generar en la región" (JUNTAEX; AUPEX, 2004d, p. 6). 
1. Sensibilizar e mostrar as possibilidades e oportunidades que as TICS [Tecnologias de Informação e Comunicação] oferecem, despertando seu interesse e gerando na população novas necessidades. Dada a heterogeneidade dos coletivos e usuários que participam dos Itinerantes, se desenham ferramentas de alfabetização em função das necessidades, interesses e perfis dos grupos e usuários. São estas ferramentas, junto com outras propostas feitas pelos próprios participantes, colaboradores e agentes sociais, as utilizadas no processo de alfabetização. (JUNTAEX; AUPEX, 2004d, p. 12, tradução nossa ${ }^{110}$ )

Para que a educação patrimonial ocorra pelos meios digitais, é importante que a comunidade seja acostumada a utilizar computadores e interfaces. Para que ela se sinta estimulada a utilizar a interface, é de maior eficiência o uso de atividades propostas pelos próprios usuários e que envolvam ações já realizadas por eles no cotidiano. Cabe aos órgãos públicos a realização de atividades para promover a interface e o incentivo a seu uso nas escolas.

2. Tecer redes de colaboração com outros organismos e instituições públicas e privadas e envolvê-los no desenvolvimento tecnológico de Extremadura. Pretende-se envolver na organização dos diferentes eventos programados, para os municípios, universidades populares, associações, centros educativos... para deste modo, criar a necessidade de investir nas TICs, engajando, criando iniciativas e somando esforços ao trem do progresso tecnológico que já está em marcha na nossa região. (JUNTAEX; AUPEX, 2004d, p. 12, tradução nossa ${ }^{111}$ )

${ }^{110}$ Do original em espanhol: "1. Sensibilizar y mostrar las posibilidades y oportunidades que ofrecen las TICS [Tecnologías de la Información y la Comunicación], despertando su interés y generando en la población nuevas necesidades. Dada la heterogeneidad de los colectivos y usuarios que participan en los Itinerantes, se diseñan herramientas de alfabetización en función de las necesidades, intereses y perfiles de los grupos y usuarios. Son estas herramientas, junto con otras propuestas hechas por los propios participantes, colaboradores y agentes sociales, las utilizadas en el proceso de alfabetización" (JUNTAEX; AUPEX, 2004d, p. 12).

${ }^{111}$ Do original em espanhol: "Tejer redes de colaboración con otros organismos e instituciones públicas y privadas e involucrarlos en el desarrollo tecnológico de Extremadura. Se persigue involucrar en la organización de los diferentes eventos programados, a los ayuntamientos, universidades populares, asociaciones, centros educativos... para de este modo, crear la necesidad de apostar por las TICs, implicándose, creando iniciativas y sumando esfuerzos al tren del progreso tecnológico que ya está en marcha en nuestra región" (JUNTAEX; AUPEX, 2004d, p. 12). 
Como já mencionado, a implementação de uma interface digital com ferramentas de interação, como e-mails ou chats, é essencial para que os agentes exerçam suas funções de forma eficiente e a preservação seja plena nos âmbitos de pesquisa, preservação e divulgação. Criando um sistema de preservação que valorize o patrimônio e justifique sua permanência.

3. Difundir a cultura local e regional através da participação e do compromisso coletivo dos vizinhos das localidades em que o PAT está presente através dos itinerantes. É um objetivo fundamental conseguir que os usuários do projeto de Alfabetização Tecnológica Itinerante participem ativamente das atividades e dos projetos que são concebidos pelo PAT como ferramentas de alfabetização tecnológica com o propósito de difundir e coletar a cultura local e regional de tais localidades, gerando um espaço de encontro social e virtual enquanto se promove a transferência de conhecimento. E uma das fórmulas mais adequadas é "levar", em seu sentido mais dinâmico, as tecnologias a populações pequenas com o objetivo de convertê-las em testemunhas de seu passado, de seu presente e da construção de seu futuro (JUNTAEX; AUPEX, 2004d, p. 12, tradução nossa ${ }^{112}$ ).

Uma população consciente da história e de sua importância melhora sua afetividade em relação aos sítios históricos e, consequentemente, auxilia na preservação dos mesmos. Além disso, percebe-se que existe uma questão de pertencimento em relação às Missões nacionais que é diferente entre os países de acordo com sua própria história (Custódio, 2014) e que não é

${ }^{112}$ Do original em espanhol: “Difundir la cultura local y regional desde la participación y el compromiso colectivo de los vecinos de las localidades donde el PAT está presente a través de los itinerantes. Es un objetivo fundamental conseguir que los usuarios del proyecto de Alfabetización Tecnológica Itinerante participen activamente en las actividades y en los proyectos que desde el PAT se diseñan como herramientas de alfabetización tecnológica con el fin de difundir y recopilar la cultura local y regional de dichas localidades, generando un espacio de encuentro social y virtual a la vez que se promueve la transferencia de conocimiento. Y una de las fórmulas más adecuadas es "Ilevar", en su sentido más dinámico, las tecnologías a poblaciones pequeñas con el fin de convertirlas en testigos de su pasado, de su presente y de la construcción de su futuro" (JUNTAEX; AUPEX, 2004d, p. 12). 
estendida ao conjunto internacional em nenhum destes países. Desse modo, é importante que as atividades de educação patrimonial sejam voltadas para modificar este olhar.

\section{Turismo, experiência e patrimônio}

Em uma sociedade atual em que se destacam as experiências e, entre elas, o desejo de viajar para conhecer culturas diferentes. Neste contexto, "[...] o patrimônio material é essencial para qualquer pessoa que queira possuir um entendimento mais profundo da sociedade. $\mathrm{O}$ que se aplica tanto aos habitantes locais quanto aos que visitam uma sociedade ou ambiente novo ou estrangeiro" (NWHF, 1999, p. 5, tradução nossa ${ }^{113}$ ). O patrimônio é crucial para a identidade local e desperta no visitante o respeito pela diversidade cultural.

As turismólogas portuguesas Elisabeth Kastenholz e Joana Lima (2011) acreditam que a experiência turística é complexa, condicionada pelos agentes locais e está imbuída da expectativa de vivenciar algo memorável e único. Segundo Elands e Lengkeek (2000 apud KASTENHOLZ; LIMA, 2011), a experiência do visitante pode ser classificada em: 1. Alegria (diversão temporária ou entretenimento familiar); 2. Mudança (fuga da vida diária ou do estresse); 3. Interesse (busca por conhecimento); 4. Arrebatamento (encantamento, desafio ou autodescoberta); ou 5. Dedicação (busca por devoção ou experiências espirituais). Cada uma dessas questões pode formular atividades que envolvam os indivíduos e propiciem a criação de laços com o patrimônio.

\footnotetext{
${ }^{113}$ Do original em inglês: "[...] material heritage is pivotal for anyone wanting to gain a deeper understanding of the society. This applies to the local inhabitants as well as the visitor to a new or foreign society or environment" (NWHF, 1999, p. 5).
} 
Desse modo, diferente do cenário atual dos espaços museológicos missioneiros abertos e fechados, em que a experiência é composta basicamente por visitas diurnas guiadas e espetáculos noturnos (onde os visitantes percorrem caminhos em meio às ruínas); estas abordagens de experiência devem ter o objetivo de provocar uma reflexão mais aprofundada sobre o lugar e sua significância. E, se "A percepção depende das relações que construímos com o ambiente/contexto de interação (ecossistema) na unidade mente-corpo" (FORTE, 2007, p. 401, tradução nossa ${ }^{114}$ ), a mudança do olhar sobre o patrimônio pode criar uma relação mais próxima com ele. Este laço mais profundo do indivíduo com o lugar e o monumento aflora o sentimento de pertencimento, que é essencial principalmente para a comunidade local como agente na preservação deste patrimônio. De acordo com Sá Neto e Guerra (2013), esta inserção da comunidade nas atividades de preservação possibilita uma revisão do conceito de cidadania e a revalorização do patrimônio proporciona a melhoria nas condições de preservação e conservação deste bem.

Um exemplo de experiência de aprofundamento da reflexão sobre o patrimônio cultural local é o curso de extensão universitária Pinhal Digital, realizado nos anos de 2003 a 2005, na cidade de São Carlos-SP ${ }^{115}$. O projeto teve o "[...] objetivo de estruturar e organizar as diversas camadas e os múltiplos aspectos da rica história da Fazenda de Café Pinhal, São Carlos. [...]" (PRATSCHKE, 2004, p. 67) (Figura 48, na próxima página). Pesquisadores, alunos de universidades e professores foram reunidos para

\footnotetext{
${ }^{114}$ Do original em inglês: "The perception depends on the relations we construct with the environment/context of interaction (ecosystem) in the unit mind-body" (FORTE, 2007, p. 401).

${ }^{115}$ Este projeto de extensão deu origens a diversos outros. Por exemplo, o Critérios e metodologias para a realização de inventário do patrimônio cultural paulista, já analisado no item Levantamento de informações e banco de dados.
} 


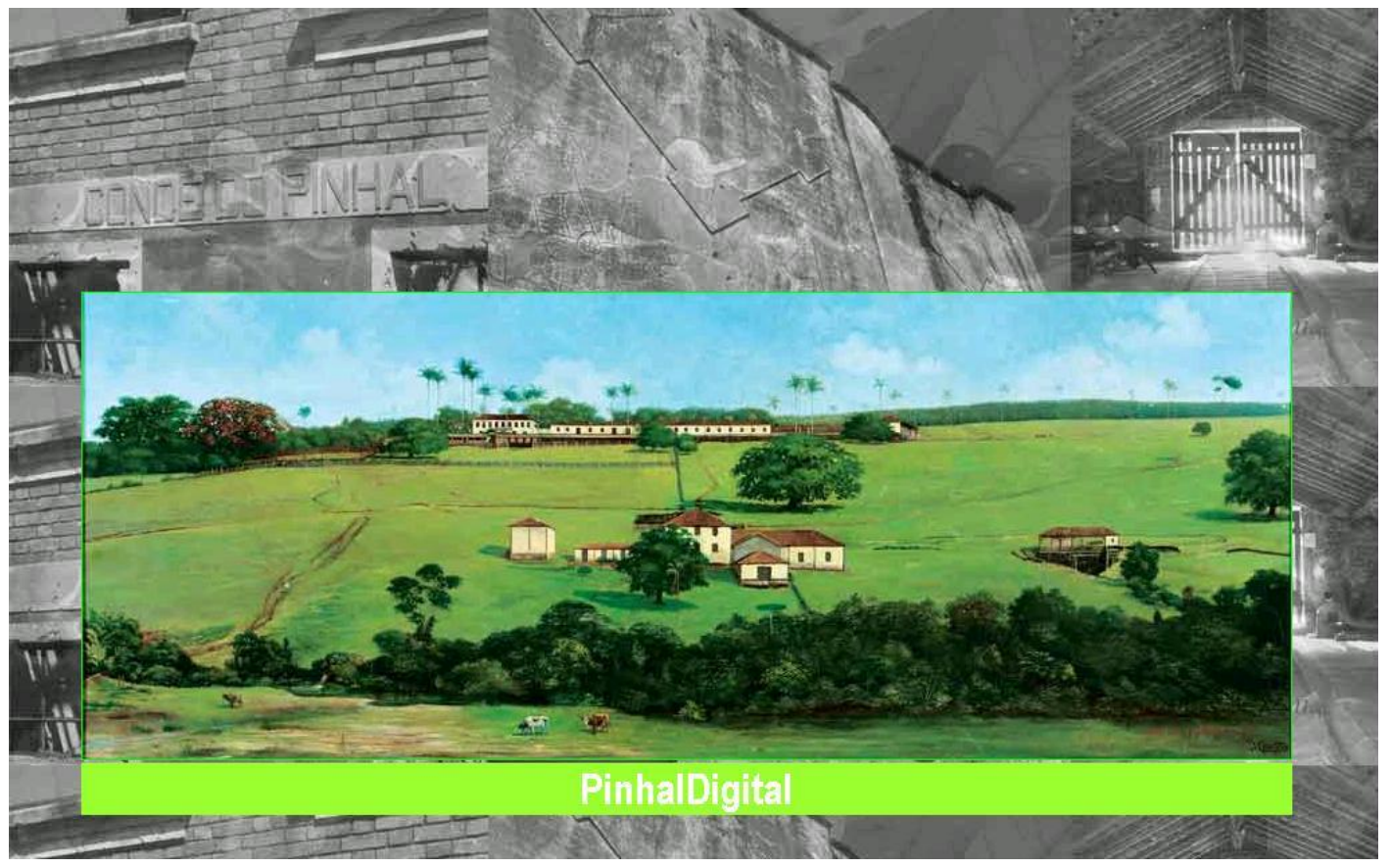

Figura 48. Site Pinhal Digital que reúne o material levantado durante o curso de extensão. Fonte: http://www.iau.usp.br/index.php/pinhal-digital 
[...] entender as diversas etapas do processo produtivo cafeeiro, levantando dados tanto do patrimônio construído da tulha e dos vestígios arquitetônicos externos, como de fontes primárias e secundárias (escritos, relatos, inventários), além da realização de entrevistas filmadas a partir de testemunhos sobre a época em que a fazenda produzia café (PRATSCHKE; BORTOLUCCl; COSTA, 2006a, p. 69).

Imersão de uma semana no cenário histórico que possibilitou o levantamento de diversos dados e teve como principal consequência a conscientização dos participantes em relação à importância deste patrimônio pelos diversos aspectos estudados. Uma mudança de olhar sobre o objeto realizada através do entendimento de sua significância, que não é possível com uma visita turística comum. No caso das Missões Jesuíticas, entende-se que esta metodologia de contato mais intenso com o patrimônio é especialmente importante para propiciar à comunidade local uma reapropriação de suas origens e ao visitante global o entendimento desta cultura.

Para auxiliar as atividades de levantamento, registro e catalogação de informações foram utilizadas mídias digitais. De acordo com as coordenadoras do projeto, as arquitetas Anja Pratschke e Maria Ângela Bortolucci e a biblioteconomista Luzia Costa (2006a, p. 67),

O uso da tecnologia de informação e comunicação, junto a Projetos de Patrimônio Cultural não é novo e diversos projetos distribuídos no mundo documentam como essa integração enriquece e nutre mutuamente o ambiente concreto e virtual tendo como objetivo a melhor compreensão sobre o objeto patrimonial cultural, preservando a memória da cultura e da história do local de forma interativa. [...].

No caso do Pinhal Digital, os participantes utilizaram tablets durante a coleta de dados, que

foram reunidos em uma plataforma online criada paralelamente. Mas será possível ainda explorar outras tecnologias pertinentes para complementar a experiência do visitante junto ao patrimônio cultural. "[...] a informação apreendida deve ser apresentada usando diferentes mídias, tais como 
imagem, som, texto, animação e vídeo. Todas estas mídias devem trabalhar juntas em dimensões diversas [...]" (MARCOS; BERNARDES; SÁ, 2002, p. 1336, tradução nossa ${ }^{116}$ ). Além disso, "O conteúdo do patrimônio virtual pode ser entregue através da internet, de museus, de exibição pública ou outros meios como APD [assistentes pessoais digitais], computadores de mão e assim por diante. Cada mídia tem suas potencialidades e limitações. [...]" (TAN; RAHAMAN, 2009, p. 150 , tradução nossa ${ }^{117}$ ). Uma tecnologia interessante atual é o celular conectado à Internet. Comum no cotidiano da população, ele geralmente conta hoje com recursos de fotografia, anotações e internet, permitindo facilidade de acesso a informações adicionais online e registro do patrimônio através dos demais recursos mencionados. Além disso, poderiam ser criados canais de comunicação durante a visitação para tirar dúvidas, comentar achados, etc.

Pode-se também utilizar o processo de concepção e realização de um audiovisual como atividade que permita ao visitante lançar outro olhar, mais reflexivo, sobre o lugar. Neste sentido, a metodologia experimentada na ação cultural CROSS_Olhares Justapostos Sobre Realidades Distantes (SOSTER; PRATSCHKE; SANTOS, 2013) propõe que o participante busque entender uma outra realidade através de pesquisas e entrevistas, e a retrate em sua própria cidade através de filmagens; o que incentiva a olhar para si mesmo em uma análise do outro, a fim de entender proximidades e diversidades entre duas culturas (no caso, a do visitante e a observada). Mas a noção de criação conjunta utilizada nesta ação pode ser utilizada com outras formas de registro,

\footnotetext{
${ }^{116}$ Do original em inglês: "[...] the apprehended information has to be presented using different media such as image, sound, text, animation and video. All these media have to work together in diverse dimensions [...]" (MARCOS; BERNARDES; SÁ, 2002, p. 1336).

${ }^{117}$ Do original em inglês: "Virtual heritage content can be delivered through internet, museum, public display or other means like PDA, handhelds and so on. Each media has its own potentials and constraints. [...]" (TAN; RAHAMAN, 2009, p. 150).
} 
como coletâneas de fotografias comparando o cotidiano dos dois lugares, que podem utilizar fotografias já possuídas pelos visitantes como tema para aquelas a serem realizadas.

Segundo Schweibenz (1998, p. 189, tradução nossa ${ }^{118}$ ), o importante não é meramente

[...] reunir objetos, mas dar aos visitantes a oportunidade de focar em seus interesses espaciais, obtendo-os em um diálogo interativo com o museu. [...] Ben Davis (1994, p. 70) chega à mesma conclusão quando afirma: "O museu digital pode ser centrado no visitante em vez de centrado no curador".

É preciso colocar em prática metodologias diferenciadas para que os museus produzam aquilo que James Clifford (1999 apud MENEZES, 2007) denomina zona de contato do visitante com o patrimônio, onde ele mesmo escolhe os caminhos a percorrer e o foco de seu interesse neste espaço. Através de suportes online, ele amplia seu conhecimento sobre as questões desejadas e isto permite um entendimento individual sobre a significância do patrimônio observado.

\subsection{Mídias em prol da complexidade do patrimônio}

A constante evolução das Tecnologias de Informação e Comunicação (TICs) culminou em sistemas que possibilitam a proliferação instantânea de conhecimento através da associação entre computador e Internet. $\mathrm{O}$ que permite reunir o conhecimento relacionado às mais diversas

\footnotetext{
${ }^{118}$ Do original em inglês: "[...] to link objects together but to give visitors the opportunity to focus on their special interests by pursuing them in an interactive dialog with the museum. [...] Ben Davis $(1994$, p. 70) reaches the same conclusion when he states: 'The digital museum can be visitor-centered rather than curator-centered'" (SCHWEIBENZ, 1998, p. 189).
} 
instâncias do patrimônio e divulgá-lo, de modo que a Web oferece uma grande quantidade e variedade de informações. Segundo Hoptman (1992 apud SCHWEIBENZ, 1998, p. 198, tradução nossa $\left.{ }^{119}\right)$,

O conceito de Museu Virtual demonstra como as limitações impostas pelo método tradicional de organização e apresentação da informação pode ser superado no contexto das visitas aos museus. Em poucas palavras, o Museu Virtual oferece múltiplos níveis, perspectivas e dimensões de informação sobre um tópico específico [...].

Links entre as informações possibilitam que o usuário produza sua própria trajetória dentro do conteúdo e o modelo de comunicação através da Internet permite a interação entre os indivíduos. A possibilidade de escolher aquilo que lhe parece mais importante e aprofundar seu conhecimento sobre este aspecto ou objeto é uma atividade que auxilia e incentiva o processo de entendimento do patrimônio. Dessa forma o usuário pode selecionar diversas fontes de informação e compará-las, reduzindo a parcialidade imposta pela subjetividade dos autores.

Os aparelhos de comunicação atuais possuem fácil utilização graças ao avanço das interfaces e, ao contrário das mídias anteriores com sua unilateralidade e impossibilidade de autênticos processos de comunicação frisada por Melo (2005), atualmente possibilitam dinâmicas coletivas diferenciadas e relações em rede a partir do compartilhamento desterritorializado e acelerado de informação. As TICs possibilitam o aprofundamento do conhecimento sobre o patrimônio devido a uma alta concentração de informações disponíveis e também colocam em sinergia todos os agentes da preservação (comunidade glocal, pesquisadores, órgãos responsáveis e guias de

\footnotetext{
${ }^{119}$ Do original em inglês: "The concept of the Virtual Museum demonstrates how limitations imposed by the traditional method of organizing and presenting information can be overcome in the context of museum visits. In a nutshell, the Virtual Museum provides multiple levels, perspectives, and dimensions of information about a particular topic [...]" (HOPTMAN, 1992 apud SCHWEIBENZ, 1998, p. 189).
} 
turismo) em busca da reapropriação do patrimônio, incentivando as relações necessárias para manter vivo o sistema de preservação das Missões, fazendo o patrimônio cumprir sua função social.

Muito além de criar ambientes 3D para jogos, a tecnologia atual abre a possibilidade para outras abordagens acadêmicas, direcionando-as ao tratamento do conhecimento como uma construção coletiva, produzindo o que Lévy chama de inteligência coletiva, pela possibilidade de colocar esses agentes em interação mediada, ampliando a criação do conhecimento. Até poucos anos atrás, este trabalho colaborativo era impossível de ocorrer na rede, mas atualmente é facilitado por ferramentas como as redes sociais e documentos colaborativos. Além disso, é cada vez mais fácil a interação entre plataformas virtuais e há uma diversidade de dispositivos de acesso fixos e móveis. Este contexto auxilia na solução de questões relacionadas ao que o engenheiro, arquiteto e cientista da computação norte-americano Alonzo Addison (2002) chama de "coordenar esforços duplicados". Existem pesquisas sobre temas parecidos sendo realizadas ao redor do mundo, mas que não são conhecidas por seus pares. Os esforços poderiam ser somados, dados compartilhados e analisados em uma produção colaborativa de conhecimento, maximizando o trabalho dos envolvidos.

Dessa maneira, o fenômeno que McLuhan (1969) denominou de "novas mídias elétricas, que estão transformando o planeta em uma aldeia global", amplia o potencial do pensamento humano pela velocidade, qualidade e capacidade de transmissão de dados através das redes. 0 que também afeta os espaços de suporte da memória, que tem sido convertida para bases digitais desde as últimas décadas do séc. XX. 
A conversão para o virtual não anula o espaço concreto. Ao contrário, é possibilitadora de uma ampliação do bem patrimonial. De modo que o ambiente online relacionado a um patrimônio cultural pode ser projetado como um espaço de encontro entre indivíduo e a cultura representada, onde são acumuladas e trocadas informações, através de pesquisa e de inserção de dados. Torna-se um local que propicia à comunidade a formação de laços afetivos com sua história e sua cultura, formando o sentimento de pertencimento tão importante para justificar a permanência do patrimônio.

De acordo com Antônio Carlos Sartini (2014), diretor do Museu da Língua Portuguesa, o museu do futuro é o que melhor souber se comunicar com seu público. Neste sentido, esta pesquisa entende que as mídias digitais são potenciais ferramentas para a importante mudança metodológica necessária para a preservação das Missões Jesuíticas, pois podem auxiliar na realização de todas as funções museológicas: a pesquisa através do registro dos dados e de sua disponibilização para análise pelos agentes envolvidos no sistema (pesquisadores, órgãos responsáveis, guias de turismo e comunidade), criando novos conhecimentos; a preservação através do próprio registro em informações multimídia (inclusive de representações em 3D); e a divulgação através da disponibilização destes dados online.

Embora atualmente não seja uma realidade nas Missões Mesuíticas, as ferramentas possibilitadas pela evolução das TICs, representadas por sua expressão mais simples - a base de dados online -, de acordo com Ferreira et al (2000), são utilizadas na área do patrimônio desde a década de 1980, e , segundo Custódio (2014), houve um árduo trabalho de digitalização com duração de dez anos junto ao sítio missioneiro de São Miguel - Brasil, o projeto foi abandonado. Esta aliança entre concreto e virtual não anula o espaço concreto de um museu; ao contrário, o complementa e possibilita a criação coletiva de conhecimentos, incentivando as interações 
essenciais para o sistema. É possibilitadora de uma ampliação do bem patrimonial, pois pode ser projetada como o que Clifford (1999 apud MENEZES, 2007) chama de zona de contato: um lugar de encontro entre o indivíduo e a cultura representada, possibilitando a acumulação e a troca de informações entre os diversos agentes deste sistema, através da entrada e saída de dados. Tornase um local que propicia à comunidade a formação de laços afetivos com sua história e sua cultura, sentimento de pertencimento tão importante para justificar a permanência do patrimônio, pois, como enfatiza o historiador francês François Hartog (2006, p. 266), o patrimônio é símbolo de sua identidade nacional. Desse modo, a psicóloga Jô Gondar e a comunicóloga Vera Dodebei (2005) afirmam que este sistema de valores patrimoniais também é importante ferramenta para a unificação da comunidade local.

Existem três instâncias em que o museu pode incluir a virtualidade em seus processos com a finalidade de registrar, preservar e divulgar o patrimônio. A primeira é interna e utiliza aplicativos que podem ser acessados unicamente no ambiente do museu ou a partir de seus recursos eletrônicos locais. São utilizadas basicamente para organização dos acervos e acesso a eles pelo público. A segunda possibilidade é externa e envolve a disponibilização do conteúdo dos acervos de maneira online em portal desenvolvido para a instituição. Esta ação possibilita uma melhor análise do patrimônio pelo acesso que o público tem a informações novas e restritas, como imagens de livros raros não disponíveis para consulta local por sua fragilidade. Esta forma de aplicação da virtualidade no museu também amplia sua atuação, pois, como salienta Liew (2005), a exibição física é limitada em alcance demográfico. O que ocorre por questões restritivas como necessidade de deslocamento até o local do museu e horários de funcionamento.

Existe ainda uma terceira possibilidade, interna e externa, que deveria ser aliada a estas duas primeiras: a disponibilização de ferramentas de comunicação in loco e online entre as instituições 
e entre os agentes envolvidos no sistema de preservação. Neste sentido, as tecnologias que envolvem o que Jorge León M. (UNAM, 2013), diretor de projetos da Universidad Abierta y Educación a Distancia da Universidad Nacional Autónoma de México, chama de entornos virtuais de aprendizagem ou plataformas para ensino e aprendizagem podem ser utilizadas para a organização de uma espécie de rede social com ferramentas para comunicação entre os envolvidos (como fóruns, chats, e-mails, wikis e redes sociais) e compartilhamento de informações (como artigos publicados sobre o tema). O que atende ao compromisso social de levar a informação ao maior número possível de pessoas e, dessa forma, aprofunda as relações da sociedade com sua memória e sua cultura. Cria-se o que McLuhan (1979 [1964]) chama de extensão tecnológica da consciência e o arquiteto brasileiro Carlos Alberto Sá Filho (2006) entende como uma extensão também de um ser coletivo e suas tão necessárias identidade e memória.

Percebe-se que várias mídias podem ser utilizadas para aprimorar a experiência do visitante junto ao patrimônio cultural e sua consequente reflexão. E, segundo Silberman (2005, p. 11, tradução nossa $\left.{ }^{120}\right)$,

[...] Devemos aplicar nossa tecnologia para [...] [a] criação de instituições locais vivas, não monumentos estáticos - sustentáveis em longo prazo não por causa de sua aparência ou da informação que contêm, mas por quão eficientemente elas funcionam como centros para reflexão comum, autoafirmação, questionamento produtivo, e consciência histórica dentro de cada comunidade.

\footnotetext{
${ }^{120}$ Do original em inglês: "[...] We must apply our technology to more closely monitoring current heritage practices and developing new forms of cultural communication programs - in which success lies not only in professional competence, technology and rational planning, but in the creation of lively local institutions, not static monuments sustainable in the long run not because of how they look or what information they contain, but for how effectively they function as centers for common reflection, self-assertion, productive questioning, and historical awareness within every community" (SILBERMAN, 2005, p. 11).
} 
No Museum of Modern Art - MoMA, em Nova lorque, o visitante é convidado a observar por mais tempo uma única obra e sua reflexão é direcionada pelo guia através de questionamentos e informações pertinentes ${ }^{121}$. Novamente ressalta-se o papel fundamental do guia de turismo como elo entre a informação e o patrimônio, e agente alterador do olhar do visitante. Portanto, é essencial a escolha de bons profissionais e seu treinamento para uma atuação mais eficiente dentro de metodologias que propiciem uma experiência museológica reflexiva. Sartini (2014) os denomina educadores, pois entende sua função de modo diferenciado, atribuindo-lhes não somente a recepção ao público e as visitas guiadas. No Museu da Língua Portuguesa, em São Paulo, são responsáveis por ações de sensibilização do público no entorno e pelo desenvolvimento de material educativo para a população e para os professores que acompanham as excursões ao local. Após o agendamento da visita, os professores recebem material educativo com sugestões de roteiro e de exercícios a serem realizados em aula sobre o museu. Tal abordagem poderia ser utilizada para as Missões Jesuíticas, formando profissionais mais envolvidos com o tema e transformando-os em agentes de informação.

Outra opção para a mudança do olhar do visitante está relacionada ao turismo, onde se pode integrar diversos elementos patrimoniais das regiões em itinerários temáticos (como o já formulado, mas ainda não implantado, Circuito Internacional das Missões) e proporcionar experiências diferenciadas, com a finalidade de criar os vínculos essenciais entre e com os lugares por onde os viajantes devem passar. Na região das Missões Jesuíticas é possível criar todos os tipos de experiência citados por Kastenholz e Lima (2011): alegria, mudança, interesse, arrebatamento e dedicação. Poderiam ser realizados também pequenos cursos de técnicos de

\footnotetext{
${ }^{121}$ Ver Mazzola (2013).
} 
artesanato ou de conservação e preservação do patrimônio, com a finalidade de que o indivíduo permaneça mais tempo dentro do sítio histórico, desenvolvendo uma atividade que lhe é de interesse e propiciando uma afeição pelo lugar. Poderiam ser realizadas também atividades temáticas, criando uma imersão em diversos aspectos do cotidiano e da arquitetura missioneiros e abordando diversas de suas múltiplas dimensões. Estes cursos e experiências patrimoniais podem (e devem) ser criados através da interação entre os quatro grupos de agentes: organizadas pelos órgãos responsáveis com conhecimento e monitoria dos pesquisadores e das respectivas universidades, com o auxílio dos guias de turismo e da comunidade local, tendo como públicoalvo a comunidade glocal. Desse modo cria-se uma relação mais próxima entre todos os agentes deste sistema, fazendo com que ele funcione de maneira mais eficiente.

Neste contexto, as novas indústrias da cultura, como são chamadas por Rifkin (2000 apud NOJIMOTO, 2009), disponibilizam roteiros que proporcionam experiências de vida. Estas atividades geram não somente benefícios econômicos para as regiões visitadas, mas fazem cumprir o propósito do patrimônio como disseminador da cultura e da história de uma comunidade, criando espaços estruturados para valorizar e disseminar o patrimônio cultural local.

Os exemplos de meios digitais analisados neste capítulo demonstram uma abordagem diferenciada para as Missões Jesuíticas: 1. metodologias mais eficazes e completas de levantamento de informações e a criação de um banco de dados que possibilite a construção e disseminação deste conhecimento em âmbito internacional; 2. uma linguagem de programação que viabilize o retorno de informações sem as restrições de idiomas, o que possibilita a coleta e a disseminação do patrimônio imaterial indígena; 3. uma alfabetização tecnológica que vise ao envolvimento da comunidade com a interface utilizada de modo a valorizar o patrimônio; 4. uma metodologia de visitação diferenciada, que incentive uma reflexão ainda mais aprofundada sobre 
o monumento. Dessa forma, propõe-se um olhar diferenciado sobre as atividades envolvidas neste ciclo de preservação que se inicia com a inserção das informações levantadas na base de dados e se encerra na formação de olhares mais críticos em relação ao patrimônio, que podem também gerar novos conhecimentos a serem inseridos na base de dados.

Estas possibilidades comunicacionais atuais podem ser facilmente inseridas nos espaços museológicos das Missões Jesuíticas e em suas várias atividades A disponibilização integrada das informações sobre os acervos missioneiros seria alterada pelo uso das TICs: os museus já não seriam lugares que deveriam (e só poderiam) ser visitados fisicamente. $E$, ao mesmo tempo, os espaços online de aprendizagem, por serem redes de disponibilização de informações e produção de conhecimentos, permitiriam uma metodologia diferenciada de interação entre os agentes museológicos e o visitante in loco ou online, como afirmam Crow e Din (2010). Neste contexto, concorda-se com Anderson (apud DIN; HECHT, 2004, contracapa, tradução nossa ${ }^{122}$ ) quando afirma que "O Museu Digital dá aos avanços tecnológicos o contexto tão necessário em tudo, desde os dispositivos portáteis até a computação social". Forte (2007) ainda entende que esta conversão do patrimônio para os meios digitais o recapitaliza como objeto físico, agregando valor a ele pela ampla disseminação de sua importância e significado.

Contudo, percebe-se que as ferramentas analisadas durante a pesquisa ainda concentram sua atuação sobre a catalogação e a divulgação das informações, de modo que, durante esta pesquisa não foi encontrado um banco de dados que inclua ferramentas para a interação entre os agentes, como e-mails e chats. Contudo, o meio acadêmico mundial há vários anos já demonstra

\footnotetext{
${ }^{122}$ Do original em inglês: "The Digital Museum gives much-needed context to recent technological advances in everything from handheld devices to social computing" (ANDERSON apud DIN; HECHT, 2004, contracapa, 2007, contracapa).
} 
interesse por esta área do uso das mídias digitais para a preservação do patrimônio e as pesquisas têm avançado no desenvolvimento de interfaces com estas propostas. 
CONSIDERAÇÕES

FINAIS 
Imagem da página anterior: São Miguel - Brasil (CHAROLA; MAGADÁN, 2009, p. 199). 
O objetivo desta pesquisa foi validar a necessidade de estudar, preservar e divulgar as Missões Jesuíticas de maneira complexa. Cada um dos capítulos desenvolvidos ao longo desta discussão abordou um destes três pontos.

No Capítulo 1, percebeu-se como as Missões Jesuíticas formaram um todo complexo: uma sociedade solidária de auxílio mútuo no interior dos aldeamentos e também entre eles. Foram apontados aspectos organizacionais e sociais moldados pela interação entre as duas culturas, a espanhola e a indígena, que se hibridizaram ao conviverem em um sistema cultural complexo. Foi um projeto original de integração social concebido na Europa e realizado na América, onde foi adaptado às possibilidades locais. Dessa forma, enfatizou-se a necessidade de olhar o passado de maneira complexa, entendendo as relações ocorridas entre os diversos elementos envolvidos.

No Capítulo 2, analisou-se o presente das Missões Jesuíticas em seus vestígios legados pelo passado, afetados e reduzidos por guerras, pela ação do tempo e da mão do ser humano. Após a expulsão dos jesuítas, que colocou um ponto final nesta experiência, a hibernação das ruínas foi quebrada pela atuação de órgãos nacionais, que passaram a entendê-las, organizá-las e divulgálas separadamente ou em grupos nacionais, desfigurando a rede que marcou durante mais de um século as Missões Jesuíticas. Percebeu-se que é preciso analisar de maneira complexa a preservação atual e propor caminhos para sua maior efetividade através de meios que propiciem e incentivem a comunicação entre os diversos agentes deste que pode ser chamado de sistema de preservação do patrimônio missioneiro: órgãos responsáveis, pesquisadores, guias de turismo e comunidade glocal. Um fluxo melhorado de informações promoverá um melhor entendimento das Missões Jesuíticas e fará com que sua função social de suporte da memória e base de reflexão histórica e social seja maximizado. 
Como resposta a esta necessidade, no Capítulo 3 foi proposta a análise de meios digitais como potencializadores destas interações necessárias para este sistema. O que ocorreria através da divulgação sem limites geográficos e da disponibilização de canais de comunicação entre os agentes, em uma bidirecionalidade comunicacional impossível em outras mídias. A possibilidade de transformar todos os agentes do sistema em receptores e emissores propiciaria, dentre tantas vantagens, a coleta da memória da comunidade local, tão esquecida pela preservação, imortalizando o patrimônio imaterial da região.

Através das diversas tecnologias analisadas neste último capítulo, percebe-se as amplas possibilidades. Como as nações demonstram consciência da importância do conjunto, pois incentivam rotas turísticas nacionais, frisam a importância da colaboração internacional em evento realizado em 2003 no Brasil, e já houve uma intensa interação entre responsáveis técnicos através da Comissão Técnica do Patrimônio do Mercosul, entende-se que a situação se alterou nos últimos anos por entraves burocráticos. Reavivar esta Comissão seria de extrema importância para que se desse continuidade às ações necessárias para a preservação e divulgação integrada do patrimônio missioneiro, desde a implementação e alimentação de uma base de dados sobre as Missões Jesuíticas, até o fornecimento de apoio técnico para as ações concretas necessárias.

Contudo, as atividades relacionadas à restauração e à manutenção dos remanescentes físicos têm exigido grandes esforços dos órgãos responsáveis. Diante disto, percebe-se que a questão da virtualização das informações e da disponibilização do conhecimento ainda recebe pouca atenção destes agentes nacionais. A fim de possibilitar estes trabalhos específicos, poder-se-ia criar parcerias com pesquisadores e universidades dos países envolvidos, formando equipes multidisciplinares e multinacionais. 
O olhar sistêmico sobre a atualidade das Missões Jesuíticas permitiu entender que, além de rever a gestão e divulgação do patrimônio missioneiro, também é preciso mudar a relação do visitante com o monumento. Se fosse adotada uma postura reflexiva mais profunda sobre o patrimônio, através de atividades diferenciadas, entende-se que seriam criados laços mais fortes entre a comunidade glocal e o patrimônio. Tais atividades poderiam envolver visitas mais reflexivas aos espaços museológicos, onde o guia conduzisse o visitante a uma observação do patrimônio mais longa e pontuada por questionamentos e contextualizações. Também poderiam ser realizados cursos envolvendo diversos aspectos das Missões Jesuíticas, tais como o cotidiano, a cultura e os modos de fazer.

Ao longo desta pesquisa, também foi percebida a importância de analisar os diversos elementos e interações que compuseram as Missões no passado e que formam o atual sistema de preservação. Mas, acima de tudo, este olhar frisou a necessidade de observar passado, presente e futuro como aspectos de um mesmo conjunto, que se transforma com o passar do tempo e as ações do ser humano, e que deve ser analisado em sua trajetória para traçar meios de potencializar suas consequências em prol do entendimento e da apropriação deste patrimônio tão único por parte da comunidade glocal, justificando a importância de sua permanência. 
224 


\section{REFERÊNCIAS BIBLIOGRÁFICAS}

ADDISON, Alonzo C. Virtual Heritage: technology in the service of culture. Association for Computing Machinery, p. 343-354 e 380, 2002.

AGUILAR, Jurandir Coronado. Conquista espiritual: a história da evangelização na província Guairá na obra de Antônio Ruiz de Montoya, s.I. (1585-1652). Roma: Editrice Pontificia Università Gregoriana, 2002.

ALTHUSSER, Louis. Ideologia e aparelhos ideológicos do estado. Lisboa: Presença, 1970.

ALVES JR., Gilberto. Web 2.0: a nova internet é uma plataforma. 2005. [online] Disponível em: <http://webinsider.com.br/2005/12/07/web-20-a-nova-internet-e-uma-plataforma/>. Acesso em: Nov. 2013.

AMAZONA, Jazmin. Entrevista concedida a Sandra Schmitt Soster via e-mail. Trinidad, Paraguai. Fev. 2014.

ANDRIOTTI, Décio. A ópera na integração. In: CLEMENTE, Elvo (Org.). Integração: artes, letras e história. Porto Alegre: EDI-PUCRS, 1995, p. 19-40.

ASHBY, William Ross. Principles of the self-organizing system. E:CO, v. 6, n. 1-2, p. 102-126, 2004. Special Double Issue. Publicado pela primeira vez em outro meio no ano de 1962. Disponível em: <http://csis.pace.edu/ marchese/CS396x/ Computing/Ashby.pdf>. Acesso em: Fev. 2014.

AYALA, Myriam M. Entrevista concedida a Sandra Schmitt Soster. Posadas, Argentina. Jan. 2013.

AYALA, Myriam M. Entrevista concedida a Sandra Schmitt Soster via e-mail. Posadas, Argentina. Fev. 2014.

BALLESTER, Candice. Entrevista concedida a Sandra Schmitt Soster. São Miguel, Brasil. Jan. 2011.

BAPTISTA, Jean. 0 eterno. Dossiê Missões v.2. São Miguel das Missões: Museu das Missões, 2009b.

BAPTISTA, Jean. 0 temporal. Dossiê Missões v.1. São Miguel das Missões: Museu das Missões, 2009a.

BAPTISTA, Jean; SANTOS, Maria Cristina dos. As ruínas. Dossiê Missões v.3. São Miguel das Missões: Museu das Missões, 2009.

BARBACCI, Norma; GREMENTIERI, Fábio. Ações executadas: Oficina técnica 2002. In: World Monuments Fund (Org.). Missões Jesuíticas dos Guarani: programa de capacitação para conservação, gestão e desenvolvimento sustentável das Missões Jesuíticas dos Guarani. World Monuments Fund: Brasília, 2004a, p. 27-32. 
BARBACCI, Norma; GREMENTIERI, Fábio. Avaliação do conjunto patrimonial. Relatório da oficina técnica 2002. In: World Monuments Fund (Org.). Missões Jesuíticas dos Guarani: programa de capacitação para conservação, gestão e desenvolvimento sustentável das Missões Jesuíticas dos Guarani. World Monuments Fund: Brasília, 2004b, p. 19-20.

BAUER, Letícia. Apresentação: dos atos de guardar. In: BAPTISTA, Jean. 0 temporal. Dossiê Missões v.1. São Miguel das Missões: Museu das Missões, 2009a, p. 7-10.

BERRUETA, Diego; POLO, Luis. Enhancing web searches within the principality of Asturias. Espanha: CTIC Foundation and the University of Oviedo, Ago. 2007. [online] Disponível em: <http://www.w3.org/2001/ sw/sweo/public/UseCases/CTIC/>. Acesso em: Mai. 2011.

BERTALANFFY, Karl Ludwing Von. Teoria geral dos sistemas. Petrópolis: Vozes, 1977.

BIESEK, Ana Solange. Os jesuítas guarani: integração do espaço ocupado no Brasil, Paraguai e Argentina na época da colonização indígena através do processo de globalização. In: SIMPÓSIO NACIONAL DE GEOGRAFIA POLÍTICA, TERRITÓRIO E PODER, 1., 01-04 Jun. 2009, Curitiba. Anais... 2009. [online] Disponível em: <http://www.nilsonfraga.com.br/ anais/BIESEK_Ana_Solange.pdf>. Acesso em: Mai. 2013.

BOFF, Claudete. Persuadir ou deixar-se persuadir: a produção artística dos povoados missioneiros do sul do Brasil. Pindorama, Universidade Federal do Rio Grande do Sul, 2006. [online] Disponível em: <http://www6.ufrgs.br/artecolonial/pindorama/art5_p.htm>. Acesso em: Mai. 2012.

BOLONHANI, Satilio. Ano dos primeiros jesuítas. In: Jesuítas. Ago. de 2006. [Blog online] Disponível em: <satbolonhani.blogspot.com.br/2006_08_03archive.html>. Acesso em: Set. 2012.

BRIGGS, Asa; BURKE, Peter. Uma história social da mídia: de Gutenberg à Internet. Rio de Janeiro: Jorge Zahar Ed., 2004.

BRUM, Ceres Karam. "Esta terra tem dono": Representações do passado missioneiro no Rio Grande do Sul. O mito de Sepé Tiaraju. ANTHROPOLÓGICAS, ano 11, v. 18(2), p. 215-236, 2007.

BRUXELS, Arnaldo. Los treinta pueblos guaranies: panorama histórico-institucional. Posadas: Ediciones Montoya, 1984.

BURKE, Mary. The semantic web and the digital library. Aslib proceedings: new information perspectives, 2009, p. 316-322.

CABRAL, Salvador et al. The environment and the aboriginal culture. In: UNESCO; ICOMOS (Orgs.). The Jesuit missions of the Guarani. Verona: Commercial Bureau, 1997, p. 20-45.

CAMARGO, Ana Paula Leite de; SANTOS, Isabel Pereira dos. Bibliotecas virtuais e multimídia. In: André Barbosa Filho, Cosette Castro, Takashi Tome (Orgs.). Mídias digitais: convergência tecnológica e inclusão social. São Paulo: Paulinas, 2005, p. 339-357. 
CAMERON, Fiona. Beyonf the cult of the replicant: museums and historical digital objects - traditional concerns, new discourses. In: CAMERON, Fiona; KENDERDINE, Sarah (Eds.). Theorizing digital cultural heritage: a critical discourse. Cambridge: MIT Press, 2007, p. 49-75.

CAMPBELL, D. Grant; FAST, Karl V. Academic libraries and the semantic web: what the future may hold for research-supporting library catalogues. The journal of Academic Librarianship, v. 30, n. 5, p. 382-390, Ago. 2004.

CARNEIRO FILHO, Camilo Pereira; SANTOS, Christiano Ricardo dos. O turismo histórico na região transfronteiriça das Missões Jesuíticas. PRACS: Revista Eletrônica de Humanidades do Curso de Ciências Sociais da UNIFAP, Macapá, n. 5, p. 151-164, dez. 2012. [online] Disponível em: <http://fazendinha. unifap.br/revista/index.php/pracs/article/ view/583/n5Carneiro.pdf>. Acesso em: Mai. 2013.

CARRILHO, Marcos José. A transparência do Museu das Missões. Arquitextos, ano 7, Set. 2006. [online] Disponível em: <http://www.vitruvius.com.br/revistas/read/arquitextos/07.076/322>. Acesso em: Set. 2012.

CARTA de Atenas. Atenas: Escritório Internacional dos Museus Sociedade das Nações, 1931. [online] Disponível em: <http://portal.iphan.gov.br/portal/baixaFcdAnexo.do;jsessionid=A7D6C7ABD105D85B582 8EE5F905FD107?id=232>. Acesso em: Dez. 2013.

CASTELLS, Manuel. A galáxia da internet: reflexões sobre a internet, os negócios e a sociedade. Rio de Janeiro: Jorge Zahar, 2003.

CHAGAS, Mário de Souza et al. Museus e público jovem: percepções e receptividades. MUSEOLOGIA E PATRIMÔNIO, v.3, n.1, p. 49-66, jan/jun 2010.

CHAN NÚÑEZ, Maria Elena. Entornos de aprendizaje digitales. Revista Digital Universitaria, México, v. 5, n. 10, Nov. 2004. [online] Disponível em: <http://www.revista.unam.mx/vol.5/num10/art68/int68.htm>. Acesso em: Jun. 2013.

CHAROLA, A. Elena; MAGADÁN, Marcelo L. (Eds.). Manual básico de conservação para as Missões Jesuíticas: Argentina, Brasil, Paraguai. Buenos Aires: Buschi, 2009.

CHAROLA, A. Elena; MAGADÁN, Marcelo L.; LANCELLOTTI, Cristina. Materiales y técnicas de construcción: deterioro y conservación. In: World Monuments Fund (Org.). Missões Jesuíticas dos Guarani: programa de capacitação para conservação, gestão e desenvolvimento sustentável das Missões Jesuíticas dos Guarani. UNESCO: Brasília, 2003, CD.

CHOAY, Françoise. A alegoria do património. Arte e comunicação. São Paulo: UNESP, 2001.

CHUNG, Jae Eun et al. Age differences in perceptions of online community participation among non-users: an extension of the technology acceptance model. Computers in Human Behavior, n. 26, p. 1674-1684, 2010. [online] Disponível em: <http://dl.acm.org/citation. cfm?id=1853540>. Acesso em: Jun. 2011. 
CIAM. Carta de Veneza. Veneza: ICOMOS, 1964. Disponível em: <http://portal.iphan.gov.br/portal/baixa FcdAnexo.do?id=236>. Acesso em: Dez. 2013.

CORREIO do Povo. Iphan informatiza Missões Jesuíticas. Porto Alegre, 20 Set. 1998. Disponível em: <http://www.correiodopovo.com.br/jornal/infotur/N48/html/07IPHANI.htm>. Acesso em: Jun. 2014.

COSTA, Lucio. A arquitetura dos jesuítas no Brasil. ARS, São Paulo, v. 8, n. 16, 2010. [online] Disponível em: $<$ http://www.scielo.br/scielo.php?pid=S1678-53202010000200009\&script= sci_arttext\&tlng=pt $>$. Acesso em: Jan. 2012. Texto originalmente publicado na Revista do Serviço do Patrimônio Histórico e Artístico Nacional, Rio de Janeiro, n. 5, p. 105-169, 1941.

COSTA, Luzia Signoli Fernandes. Critérios e metodologias para a realização de inventário do patrimônio cultural paulista. 2012. Disponível em: <http://www.bv.fapesp.br/pt/auxilios/45936/criterios-emetodologias-para-a-realizacao-de-inventario-do-patrimonio-cultural-paulista/>. Acesso em: Jan. 2014.

COUTINHO, Fabio Luiz Borgatti. Presentación. In: MUSEO DE ARTE HISPANOAMERICANO ISAAC FERNÁNDEZ BLANCO (Org.). Misiones Jesuíticas brasileñas. Buenos Aires: Museo de arte hispanoamericano Isaac Fernández Blanco, 2000, p. 31-33.

CROW, William B.; DIN, Herminia. Unbound by place or time: museums and online learning. Washington: Amer Assn of Museums, 2009.

CULTUREPLEX. [s.d.] [website] Disponível em: <http://www.cultureplex.ca/>. Acesso em: 15 Jul. 2012.

CULTUREPLEX. BaroqueArt descriptors ontology: an ontology to formalize the way to describe an artwork. 2011. [online] Disponível em: <http://ontologies.cultureplex.ca/baroqueart/ spec/index.html>. Acesso em: Jan. 2014.

CURY, Isabelle (Org.). Cartas patrimoniais. Edições do Patrimônio. Rio de Janeiro: IPHAN, 2002.

CURY, Marília Xavier. [Sem título] In: JORNADA CULTURAL EDUCAÇÃO EM MUSEUS, 18 abr. 2012, Paranaguá-PR. Anais... Paranaguá: Centro de Memória Bunge, 2012.

CUSTÓDIO, Luiz Antonio Bolcato. A arquitetura e o urbanismo das Missões Jesuíticas dos Guaranis. In: COLÓQUIO "A CONSTRUÇÃO DO BRASIL URBANO", 2000a, Convento da Arrábida - Lisboa. Anais... Lisboa: [s.n.], 2000a. [online] Disponível em: <http://revistas.ceurban.com/numero3/artigos/artigo_06.htm>. Acesso em: Nov. 2012.

CUSTÓDIO, Luiz Antonio Bolcato. A redução de São Miguel Arcanjo: contribuição ao estudo da tipologia urbana missioneira. Dissertação (mestrado) - Faculdade de Arquitetura e Urbanismo, Programa de PósGraduação em Planejamento Urbano e Regional, Universidade Federal do Rio Grande do Sul, Porto Alegre, 2002a. 
CUSTÓDIO, Luiz Antonio Bolcato. Participação em banca de Sandra Schmitt Soster. Missões jesuíticas como sistema. 2014. Dissertação (Mestrado em Teoria e História da Arquitetura e do Urbanismo) - Instituto de Arquitetura e Urbanismo - Universidade de São Paulo, São Carlos-SP.

CUSTÓDIO, Luiz Antonio Bolcato. Missões Jesuíticas: Arquitetura e Urbanismo. Caderno de História, n. 21. Porto Alegre: Memorial do Rio Grande do Sul, 2006.

CUSTÓDIO, Luiz Antonio Bolcato. Missões Jesuíticas dos Guaranis. Brasília: INFRAERO, 1997.

CUSTÓDIO, Luiz Antonio Bolcato. Missões Jesuíticas dos guarani: trajetória de preservação e conservação: síntese retrospectiva: IPHAN - Brasil: 1925 - 2003. In: World Monuments Fund (Org.). Missões Jesuíticas dos Guarani: programa de capacitação para conservação, gestão e desenvolvimento sustentável das Missões Jesuíticas dos Guarani. World Monuments Fund: Brasília, 2004a, CD.

CUSTÓDIO, Luiz Antonio Bolcato. Referências regionais: Mercosul Cultural. In: World Monuments Fund (Org.). Missões Jesuíticas dos Guarani: programa de capacitação para conservação, gestão e desenvolvimento sustentável das Missões Jesuíticas dos Guarani. World Monuments Fund: Brasília, 2004b, p. 39-43.

CUSTÓDIO, Luiz Antônio Bolcato. Relatório síntese. Porto Alegre: Comissão técnica do patrimônio do MERCOSUL, 2002b.

CUSTÓDIO, Luiz Antônio Bolcato. [Título desconhecido] In: MUSEO DE ARTE HISPANOAMERICANO ISAAC FERNÁNDEZ BLANCO (Org.). Misiones Jesuíticas brasileñas. Buenos Aires: Museo de arte hispanoamericano Isaac Fernández Blanco, 2000b, p. 34-39.

CUSTÓDIO, Luiz Antonio Bolcato; BRUXEL, Jaime Renato. Primeiro curso-oficina - 2003. In: World Monuments Fund (Org.). Missões Jesuíticas dos Guarani: programa de capacitação para conservação, gestão e desenvolvimento sustentável das Missões Jesuíticas dos Guarani. World Monuments Fund: Brasília, 2004, p. 33-37.

DIN, Herminia; HECHT, Phyllis. The digital museum: a think guide. Washington DC: American Alliance of Museums Press, 2007.

ESCRITÓRIO Técnico I - São Miguel das Missões / 12a Superintendência Regional. Relatório de atividades: 2003-2005. São Miguel: IPHAN, 2006.

FACHIN, Patrícia. Interpretações históricas e atuais da experiência jesuítica. Trad. Moisés Sbardelotto. IHU On-Line, Instituto Humanitas Unisinos, ed. 348. São Leopoldo: Unisinos, 25 de out. 2010, p. 5-6.

FALK, John H. Situated identities and the museum visitor experience. Oregon State University, 2010. [Apresentação em Powerpoint] Disponível em: <http://visitors.org.uk/files/Audience\%20 Segmentation\%20 -\%20J\%20Falk.pdf>. Acesso em: Ago. 2013. 
FERNÁNDEZ, Maria Jesús; CAMPOS, Antonio. CRUZAR: an application of semantic matchmaking for eTourism in the city of Zaragoza. Espanha: City Council of Zaragoza and Antonio Campos; CTIC Foundation, ago. 2008. [online] Disponível em: <http://www.w3.org/2001/sw/sweo/public/UseCases/Zaragoza-2/>. Acesso em: Mai. 2011.

FERREIRA, Rosa et al. A Tecnologia Multimédia no Registo do Património Arquitectónico. In: CAPSI, 1. , Out. 2000, Guimarães - Portugal. Proceedings of... Guimarães: [s.n.], 2000. [online] Disponível em: <http://5cidade.files.wordpress.com/2008/06/ registo_patrimonio_arquitectonico.pdf >. Acesso em: Nov. 2013.

FLUSSER, Vilém. O universo das imagens técnicas: elogio da superficialidade. São Paulo: Annablume, 2008.

FORTE, Maurizio. Ecological cybernetics, virtual reality and virtual heritage. In: CAMERON, Fiona; KENDERDINE, Sarah (Eds.). Theorizing digital cultural heritage: a critical discourse. Cambridge: MIT Press, 2007, p. 389-407.

GARCÍA-CRESPO, Ángel. et al. Digital libraries and Web 3.0.: the CallimachusDL approach. Computers in Human Behavior, 2010.

GAZANEO, Jorge O. The geopolitics of the missions. In: UNESCO; ICOMOS (Orgs.). The Jesuit missions of the Guarani. Verona: Commercial Bureau, 1997, p. 74-89.

GLANVILLE, Ranulph. The purpose of second-order Cybernetics. Kybernetes, v. 33, n. 9/10, p. 1379-1386, 2004.

GONDAR, Jô; DODEBEI, Vera. Apresentação. In: GODAR, Jô; DODEBEI, Vera (Orgs.). O que é memória social? Rio de Janeiro: Contra Capa / Programa de Pós-Graduação em Memória Social da Universidade do Estado do Rio de Janeiro, 2005, p. 7-10.

GRANCE, Ricardo. Música y luces revitalizan las Ruinas de Trinidad. Ultima Hora, 20 Ago. 2009. [online] Disponível em: <http://www.ultimahora.com/musica-y-luces-revitalizan-las-ruinas-trinidad-n248389.html>. Acesso em: Dez. 2013.

GREENHALGH, Laura. Ouvindo a voz dos índios. Pesquisa FAPESP, n. 97, Mar. 2004.

GUTIÉRREZ, Ramón. As Missões Jesuíticas dos Guaranis. Rio de Janeiro: UNESCO, 1987.

GUTIÉRREZ, Ramón. As Missões Jesuíticas dos Guaranis: um espaço para a utopia. In: World Monuments Fund (Org.). Missões Jesuíticas dos Guarani: programa de capacitação para conservação, gestão e desenvolvimento sustentável das Missões Jesuíticas dos Guarani. World Monuments Fund: Brasília, 2004, p. 17-18.

HABERMAS, Jürgen. Introdução. In: André Barbosa Filho, Cosette Castro, Takashi Tome (Orgs.). Mídias digitais: convergência tecnológica e inclusão social. São Paulo: Paulinas, 2005, p. 17-23. 
HARTOG, François. Tempo e Patrimônio. VARIA HISTORIA, Belo Horizonte, v. 22, n. 36, p. 261-273, Jul./Dez. 2006.

HAZAN, Vera Magiano. Os Reflexos do mundo virtual na cidade real. Arquitextos, ano 02, Jun. 2001. [online] Disponível em: <http://www.vitruvius.com.br/revistas/read/arquitextos/02.013 /880>. Acesso em: Mar. 2011.

HERNÁNDEZ, Francisca. An ontology of Cantabria's cultural heritage. Espanha: Fundación Marcelino Botín, Mai. 2007. [online] Disponível em: <http://www.w3.org/2001/sw/sweo/public/UseCases/Foundation Botin/>. Acesso em: Mai. 2011.

HOLLINK, Laura et al. Patterns of semantic relations to improve image content search. Web Semantics: Science, Services and Agents on the World Wide Web, n. 5, p. 195-203, 2007.

HEYLIGHEN, Francis Paul. Complexity and self-organization. In: BATES, Marcia J.; MAACK, Mary Niles (Eds.). Encyclopedia of library and information sciences. Oxford: Taylor \& Francis, 2008. [online] Disponível em: <http://pespmc1.vub.ac.be/Papers/ELIS-complexity.pdf>. Acesso em: Fev. 2014.

IBAÑEZ, Mario Corcuera. Misiones Jesuíticas brasileñas. In: MUSEO DE ARTE HISPANOAMERICANO ISAAC FERNÁNDEZ BLANCO (Org.). Misiones Jesuíticas brasileñas. Buenos Aires: Museo de arte hispanoamericano Isaac Fernández Blanco, 2000, p. 19-21.

IBARRA, Aníbal. Misiones jesuíticas brasileñas. In: MUSEO DE ARTE HISPANOAMERICANO ISAAC FERNÁNDEZ BLANCO (Org.). Misiones Jesuíticas brasileñas. Buenos Aires: Museo de arte hispanoamericano Isaac Fernández Blanco, 2000, p. 11.

IBGE. Missões Jesuíticas. In: IBGE. Atlas das representações literárias de regiões brasileiras. Brasil Meridional. v. 1. IBGE: Rio de Janeiro, 2006, p. 25-30.

IBRAM. Os museus: conheça os museus do IBRAM. [s.d.] [online] Disponível em: <http://www.museus.gov. br/os-museus/>. Acesso em: Mai. 2013.

ICOMOS. World Heritage List. 1983. [online] Disponível em: <http://whc.unesco.org/archive/advisory_body _evaluation/291.pdf>. Acesso em: Abr. 2013.

ICOMOS. World Heritage List: Jesuit Missions of Paraguay. n. 648, 10 Mar. 1992, p. 89-101. [online] Disponível em: <http://whc.unesco.org/archive/advisory_body_evaluation/ 648.pdf>. Acesso em: Abr. 2013.

IPHAN. Países do Mercosul promovem a integração do patrimônio latino-americano. 15 Mai. 2008. [online] Disponível em: <http://portal.iphan.gov.br/portal/montarDetalheConteudo.do;jsessionid=0BDB255 214583352767E98BFACOE6A39?id=13924\&sigla=Noticia\&retorno=detalheNoticia>. Acesso em: Mai. 2014. 
JACOVKIS, David; TEBBENS, Wouter. Extremadura: de la cola a la vanguardia: construyendo la sociedad de la información (casi) desde cero. 2007. [online] Disponível em: <http://freeknowledge.eu/files/Extremadura _djacovkis_es.pdf>. Acesso em: Jul. 2011.

JARAMILLO, Maria Matilde Villegas. São Miguel das Missões: trajetória da preservação: 1925-2003: IPHAN Brasil. In: World Monuments Fund (Org.). Missões Jesuíticas dos Guarani: programa de capacitação para conservação, gestão e desenvolvimento sustentável das Missões Jesuíticas dos Guarani. World Monuments Fund: Brasília, 2004, CD.

JUNG, Hanmin et al. OntoFrame 2008: a semantic portal service of academic research information. Coréia: Korea Institute of Science and Technology Information (KISTI), Ago. 2009. [online] Disponível em: <http://www.w3.org/2001/sw/sweo/public/UseCases/OntoFrame/>. Acesso em: Mai. 2011.

JUNTAEX; AUPEX. Álbum fotográfico: imágenes para el recuerdo. Extremadura: AUPEX, 2004a.

JUNTAEX; AUPEX. Alfabetización tecnológica itinerante. Extremadura: AUPEX, 2004b.

JUNTAEX; AUPEX. Campanas extremeñas em la Red. Extremadura: AUPEX, 2004c.

JUNTAEX; AUPEX. Periódico digital NCC. Extremadura: AUPEX, 2004d.

KASTENHOLZ, Elisabeth; LIMA, Joana. The integral rural tourism experience from the tourist's point of view: a qualitative analysis of its nature and meaning. Tourism \& Management Studies, n. 7, Dez. 2011. [online] Disponível em: <http://www.scielo.oces.mctes.pt/scielo.php?pid=S2182-84582011000100007\&script=sci_ arttext>. Acesso em: Fev. 2014.

KERRIOU, Miriam Arroyo de. Museu, patrimônio e cultura: reflexões sobre a experiência mexicana. In: DEPARTAMENTO DO PATRIMÔNIO HISTÓRICO (Org.). O direito à memória: patrimônio histórico e cidadania. São Paulo: Departamento do Patrimônio Histórico, 1992, p. 89-99.

LEAL, Fernando Machado. São Miguel das Missões: estudo de estabilização e conservação das ruínas da igreja. Revista do Patrimônio Histórico e Artísitico Nacional, Brasília, n. 19, 1984, p. 71-96.

LEAL, José Machado. Os Guaranis. In: LEAL, José Machado. Rio Grande do Sul: histórias e tradições. Porto Alegre: Envangraf, 2008, p. 18-40.

LE GOFF, Jacques. Memória. História e memória, Campinas: UNICAMP, p. 419-476, 2003.

LEITE, Julieta. Virtual heritage network: VHN. City \& Time, v. 1(3), n. 7, p. 65-67, 2005. [online] Disponível em: <http://www.ceci-br.org/novo/revista/docs2005/CT-2005-36.pdf>. Acesso em: Jul. 2013.

LEITE, Serafim. História da Companhia de Jesus no Brasil. Tomo I. Porto: Tipografia Porto Médico, 1938, p. IX-17. Prefácio e Capítulo I.

LEVENTHAL, Laura; BARNES, Julie. Usability engineering: process, products, and examples. Nova Jersey: Pearson; Prentice Hall, 2008. 
LÉVY, Pierre. As formas do saber: tecnologia. São Paulo: FRANMI, 2001.

LÉVY, Pierre. Cibercultura. São Paulo: 34, 1999.

LIEW, Chern Li. Online cultural heritage exhibitions: a survey of information retrieval features. Emerald, v. 39, n. 1, p. 4-24, 2005.

LIMA, Maria de Fátima Monte; PRETTO, Nelson de Luca; FERREIRA, Simone de Lucena. Mídias digitais e educação: tudo ao mesmo tempo agora o tempo todo... In: André Barbosa Filho, Cosette Castro, Takashi Tome (Orgs.). Mídias digitais: convergência tecnológica e inclusão social. São Paulo: Paulinas, 2005, p. 225255.

LOBATO, Luciano. Além do uso: definindo interatividade. Set. 2009. [online] Disponível em: <http://www.lucianolobato.com.br/?p=17>. Acesso em: Jul. 2012.

MACDONALD, Lindsay (Ed.). Digital heritage: applying digital imaging to cultural heritage. Amsterdã: Butterworth-Heinemann; Elsevier, 2006, contracapa.

MCLUHAN, Marshall. Essay: The Playboy interview: a candid conversation with the high priest of popcult and metaphysician of media. Playboy Magazine, mar. 1969. [online] Disponível em: <http://www.nextnature.net/2009/12/the-playboy-interview-marshall-mcluhan/>. Acesso em: Set. 2011.

MCLUHAN, Marshall. Os meios de comunicação como extensões do homem (understanding media). 5a ed. São Paulo: Cultrix, 1979. 1a ed. 1964.

MAEDER, Ernesto J. A.; GUTIÉRREZ, Ramón. Atlas territorial e urbano das missões jesuíticas dos guaranis: Argentina, Paraguai e Brasil. Sevilha: Junta Andalucia; Instituto Andaluz del Patrimonio Histórico; Consejería de Cultura, 2010.

MALDONADO, José Carlos. Memória Virtual de São Carlos. 2004. [online] Disponível em: $<$ http://www.bv.fapesp.br/pt/pesquisa/?q=Projeto+de+Pol\%C3\%ADticas+P\%C3\%BAblicas+Mem\%C3\%B3ria +Virtual+de+S\%C3\%A3o+Carlos\&index=\&link_curto=>. Acesso em: Jan. 2014.

MARCOS, Adérito Fernandes; BERNARDES, Paulo; SÁ, Vitor. Multimedia technology and 3D environments used in the preservation and dissemination of Portuguese cultural heritage. In: MENDEZ VILLAS, A.; GONZÁLES, J. A. (Eds.). Educational Technology, Minho: Junta da Estremadura, p. 1335-1339, 2002. [online] Disponível em: <http://repositorium.sdum.uminho.pt/bitstream/1822/366/1/ArtigoCG-RV_final.pdf>. Acesso em: Dez. 2013.

MASSIMI, Marina. As idéias psicológicas na produção cultural da Companhia de Jesus no Brasil do século XVI e XVII. In: MASSIMI, Marina; GUEDES, Maria do Carmo. História da psicologia no Brasil: novos estudos. São Paulo: EDUC/Cortez, 2004, p. 27-47. 
MATURANA, Humberto; VARELA, Francisco. A árvore do conhecimento. São Paulo: Psy, 1997. 1a ed. 1987. Disponível em: <http://www.anaqueiros.com/app/download/5814062562/arvore+do+conhecimento+livro +de+humberto+maturana+e+francisco+varela.pdf?t=1380106070>. Acesso em: Fev. 2014.

MAZZOLA, Lisa. Week one lecture. Nova lorque: MoMA, 2013. [vídeo] Disponível em: <http://d396qusza40orc.cloudfront.net/artinquiry/recoded_videos\%2FA\%261\%20Week\%201\%20Lecture\%2 0\%28final\%29.6360706a63543ef1f9b293c318ed85a2.webm>. Acesso em: Ago. 2013.

MEIRA, Ana Lúcia Goelzer. As dimensões materiais e imateriais da experiência missioneira. Entrevistadoras: Patricia Fachin e Márcia Junges. IHU on-line - Revista do Instituto Humanitas Unisinos, n. 348, ano 10, 25 Out. 2010. [online] Disponível em: <http://www.ihuonline.unisinos.br/index.php?option=com_ content\&view=article\&id=3607\&secao=348>. Acesso em: Nov. 2013.

MELO, José Marques de. Prefácio. In: André Barbosa Filho, Cosette Castro, Takashi Tome (Orgs.). Mídias digitais: convergência tecnológica e inclusão social. São Paulo: Paulinas, 2005, p. 7-15.

MENDIZÁBAL, Max de. TIC en la educación en Coursera: plataformas y entornos virtuales. 04 jun. 2013. [online] Disponível em: <http://www.youtube.com/watch?feature=player_embedded \&v=MBBE5gE3Y6U>. Acesso em: Jun. 2013.

MENEZES, Ulpiano Toledo Bezerra de. Os museus na era do virtual. In: SEMINÁRIO INTERNACIONAL MUSEUS, CIÊNCIA E TECNOLOGIA, 2007, Rio de Janeiro. BITTENCOURT, José; BENCHETRIT, Sarah Fassa; GRANATO, Marcus (Orgs). Livro do... Rio de Janeiro: Museu Histórico Nacional, 2007, p. 49-70. Disponível em: <http://docvirt.com/docreader.net/docreader.aspx?bib=MHN\&pasta=Livros\%20dos\%20Seminarios\%20 Internacionais\%5C2007\%20-\%20 Museus\%20Ciencia\%20e\%20Tecnologia\&pesq=>. Acesso em: Set. 2013.

MILEKIC, Slavko. Toward tangible virtualities: tangialities. In: CAMERON, Fiona; KENDERDINE, Sarah (Eds.). Theorizing digital cultural heritage: a critical discourse. Cambridge: MIT Press, 2007, p. 369-388.

MILLER, James Grier. Living systems. Nova lorque: McGrw-Hill, 1978.

MONTEIRO, John Manuel. Os Guarani e a História do Brasil Meridional: séculos VIX-VII. In: CARNEIRO DA CUNHA, Manuela (Org.). História dos Índios no Brasil. São Paulo: Companhia das Letras, 1992, p. 475-498.

MOREIRA, Vivian Lemes; ROMÃO, Lucília Maria Sousa. Weblog, a inscrição da heterogeneidade e do sujeito na rede. Linguasagem, n. 02, [s.d.]. [online] Disponível em: <http://www.letras.ufscar.br/linguasagem/ edicao02/02ai_vlmImsr.php>. Acesso em: Jan. 2012.

MORIN, Edgar. 0 método I: a natureza da natureza. Trad. Ilana Heineberg. Porto Alegre: Sulina, 2005. 1a ed. 1970.

MORIN, Edgar; LE MOIGNE, Jean-Louis. A Inteligência da Complexidade. São Paulo: Petrópolis, 2000. 
MUJICA, Elias. Análise da situação e recomendações. In: World Monuments Fund (Org.). Missões Jesuíticas dos Guarani: programa de capacitação para conservação, gestão e desenvolvimento sustentável das Missões Jesuíticas dos Guarani. World Monuments Fund: Brasília, 2004a, p. 21-22.

MUJICA, Elias. La arqueología y el patrimonio Jesuítico Guaraní. Curso -Taller "Conservación, gestión y desarrollo sustentable de las Misiones Jesuítico Guaraníes". In: World Monuments Fund (Org.). Missões Jesuíticas dos Guarani: programa de capacitação para conservação, gestão e desenvolvimento sustentável das Missões Jesuíticas dos Guarani. World Monuments Fund: Brasília, 2004b, CD.

MÜLLER, Karl H. The BCL: an unfinished revolution of an unfinished revolution. In: MÜLLER, Albert; MÜLLER, Karl H. (Orgs.). An unfinished revolution? Wien: Echoraum, 2007, p. 408-474.

NAKAGAWA, Elisa; BIANCHI, Tiago. Sistema Memória Virtual. [Palestra] In: WORKSHOP DISPONIBILIZAÇÃO DE ACERVOS HISTÓRICOS, 1., 18 Set. 2013, São Carlos-SP.

NASCIMENTO, Ana Teresa Correia de Brito. Liga Portuguesa dos Deficientes Motores: de Instituição de Educação Especial e Reabilitação a Centro de Recursos; De Centro de Recursos a Fundação. Estudo de caso de uma organização. Tese (Doutorado) - Instituto de Estudos da Criança, Universidade do Minho, Portugal, 2008. Disponível em: <http://repositorium.sdum.uminho.pt/bitstream/1822/9528/1/tese.pdf >. Acesso em: Mai. 2011.

NEGROPONTE, Nicholas. A vida digital. 2ª ed. São Paulo: Companhia das Letras, 1995.

NOJIMOTO, Cynthia. Design para experiência: processos e sistemas digitais. Dissertação (Mestrado) Instituto de Arquitetura e Urbanismo, Universidade de São Paulo, São Carlos-SP, 2009.

NWHF. Sustainable tourism and cultural heritage: a review of development assistance and its potential to promote sustainability. 1999. [ONLINEonline] Disponível em: <http://www.nwhf.no/files/File/culture _ fulltext.pdf>. Acesso em: Fev. 2014.

OLINTO, Antonio; ASPRINO, Rafaela. Palestras e viagem ao Rio Grande do Sul. 2010 [blog] Disponível em: <http://www.olinto.com.br/novidades/Palestras\%202010/cicloturismo\%20palestra\%20poa\%2008\%202010. htm>. Acesso em: 14 Abr. 2013.

PANGARO, Paul. The Past-Future of Cybernetics: conversation, von Foerster and the BCL. In: MÜLLER, Albert, MÜLLER, Karl H. An unfinished Revolution? Viena: Echoraum, 2007, p. 144-187.

PAOLI, Maria Célia. Memória, história e cidadania: o direito ao passado. In: DEPARTAMENTO DO PATRIMÔNIO HISTÓRICO (Org.). O direito à memória: patrimônio histórico e cidadania. São Paulo: Departamento do Patrimônio Histórico, 1992, p. 25-28.

PARAGUAI. Lei $n^{\circ} 1.388$, de 30 de dezembro de 1998. [online] Disponível em: <http://www.senatur.gov.py/ index.php?option=com_docman\&ltemid=107>. Acesso em: Abr. 2013. 
PAREDE, Edgar. Entrevista concedida a Sandra Schmitt Soster. Trinidad, Paraguai. Jan. 2013.

PARENT, Michel; BAETA LEAL, Claudia Feierabend. O Estado do Rio Grande do Sul: São Miguel e as "reduções indígenas". In: PARENT, Michel; BAETA LEAL, Claudia Feierabend. As Missões da UNESCO no Brasil: Michael Parent. Coleção Pesquisa e documentação do IPAHN. Rio de Janeiro: Ministério da Cultura; IPHAN, 2009, p. 152-155.

PATETTA, Luciano. A arquitectura da Companhia de Jesus: entre maneirismo e barroco. In: CONGRESSO INTERNACIONAL DO BARROCO, 2., 2001, Porto; Vila Real; Aveiro; Arouca - Portugal. Atas... Porto; Vila Real; Aveiro; Arouca - Portugal: [s.n.], 2001, p. 389-400. [online] Disponível em: <http://ler.letras.up.pt/uploads/ ficheiros/7549.pdf>. Acesso em: Nov. 2012.

PAULA, Roberto de. The architecture of the Missions of Guayrá. In: UNESCO; ICOMOS (Orgs.). The Jesuit missions of the Guarani. Verona: Commercial Bureau, 1997, p. 90-153.

PESAVENTO, Sandra. Ruínas falantes, fonte de imaginação. In: BAPTISTA, Jean; SANTOS, Maria Cristina dos. As ruínas. Dossiê Missões v.3. São Miguel das Missões: Museu das Missões, 2009, p. 11-15.

PETRY, Sandra. Entrevista concedida a Sandra Schmitt Soster. São Miguel, Brasil. Jan. 2013.

PICKERING, Andrew. Cybernetics and the mangle: Ashby, Beer and Pask. Social Studies of Science, v. 3, n. 32, p. 413-437, 25 abr. 2002.

POENITZ, Alfredo J. Erich. Um proyecto de arqueología histórica. El ámbito rural de las Misiones en la cuenca del río Aguapey. In: World Monuments Fund (Org.). Missões Jesuíticas dos Guarani: programa de capacitação para conservação, gestão e desenvolvimento sustentável das Missões Jesuíticas dos Guarani. World Monuments Fund: Brasília, 2004, CD.

POLITOU, Eugenia A.; PAVLIDIS, George P.; CHAMZAS, Christodoulos. JPEG2000 and dissemination of cultural heritage over the Internet. IEEE Transactions on Image Processing, v. 13, n. 3, Mar. 2004.

POUJADE, Ruth Adela. Arqueología reducional jesuítica guaraní em Misiones - Argentina. In: World Monuments Fund (Org.). Missões Jesuíticas dos Guarani: programa de capacitação para conservação, gestão e desenvolvimento sustentável das Missões Jesuíticas dos Guarani. World Monuments Fund: Brasília, 2004, CD.

PRADO, Cláudio; CAMINATI, Francisco; NOVAES, Thiago. Sinapse XXI: novos paradigmas em comunicação. In: André Barbosa Filho, Cosette Castro, Takashi Tome (Orgs.). Mídias digitais: convergência tecnológica e inclusão social. São Paulo: Paulinas, 2005, p. 25-49.

PRATSCHKE, Anja. Pinhal digital: estrutura mnemônica e processos multimídia nas fazendas de café: História, arquitetura e tecnologia. In: IBEROAMERICAN CONGRESS OF DIGITAL GRAPHICS, 8., 2004, Porto Alegre. Proceedings of... Porto Alegre: [s.n.], 2004. [online] Disponível em: <http://cumincad.scix.net/cgibin/works/Show?_id=sigradi2004_197\&sort=DEFAULT\&search=\%2Fseries\%3A\%22SIGRADI\%22\&hits=1527> Acesso em: Fev. 2014. 
PRATSCHKE, Anja; BORTOLUCCI, Maria Ângela Pereira de Castro; COSTA, Luzia Sigoli Fernandes. Mesclando realidades: múltiplos olhares sobre um patrimônio rural. [Apresentação em Powerpoint] In: CAFÉ COM PESQUISA, 2006.

PRATSCHKE, Anja; BORTOLUCCI, Maria Ângela Pereira de Castro; COSTA, Luzia Sigoli Fernandes. Pinhal digital: uma experiência de transdisciplinaridade. In: KURI, Nídia Pavan; SILVA, Antônio Nélson Rodrigues da (Orgs.). O ensino no Campus USP São Carlos: inovações e inovadores. V. 1. São Carlos-SP: CETEPE-USP, 2006a, p. 67-86.

PRATSCHKE, Anja; SANTIAGO, Rodrigo Peronti. Olhares múltiplos, ou como conceber um espaço de conhecimento para a cidade de São Carlos. In: SIGRADI, 10., 2006, Santiago de Chile. Post Digital, v. 1. Santiago de Chile: Universidad de Chile, 2006, p. 377-380. [online] Disponível em: <http://www.nomads. usp.br/pesquisas/cultura_digital/lembrancas_digitais/artigo_OlharesMultiplos.pdf>. Acesso em: Mai. 2012.

POZZOBON, José Luiz. Misiones: las reducciones jesuiticas. In: World Monuments Fund (Org.). Missões Jesuíticas dos Guarani: programa de capacitação para conservação, gestão e desenvolvimento sustentável das Missões Jesuíticas dos Guarani. World Monuments Fund: Brasília, 2004, CD.

RIBEIRO, Darcy. O povo brasileiro: a formação e o sentido do Brasil. 2a ed. São Paulo: Companhia das Letras, 1995.

ROCHA, Isabel Amalia Medero. Projeto Missões, Computação Gráfica: uma trajetória de razão e sensibilidade. In: COMPUTAÇÃO GRÁFICA: PESQUISAS E PROJETOS RUMO À EDUCAÇÃO PATRIMONIAL, 4-6 Nov. 2008, São Paulo. Anais... São Paulo: [s.n.], 2008. [online] Disponível em: <http://www.arquiamigos. org.br/seminario3d/pdf/isabel-missoes.pdf>. Acesso em: Mar. 2014.

RODRÍGUEZ, Marta González. Online resource for information on aquatic sciences. Espanha: Tecnalia, Jul. 2009. [online] Disponível em: <http://www.w3.org/2001/sw/sweo/public/ UseCases/Aquaring/>. Acesso em: 10 Mai. 2011.

ROJAS-SOLA, José Ignacio; CASTRO-GARCíA, Miguel; CARRANZA-CAÑADAS, María del Pilar. Content management system incorporated in a virtual museum hosting. Journal of Cultural Heritage, n. 12, p. 7481, 2011.

ROVIRA, Carlos Eduardo. Preservar para legar. In: SNIHUR, Esteban Angel. 0 universo missioneiro guarani: um território e um patrimônio. Buenos Aires: Golden Company, 2007, p. 5.

RUSSO, Angelina; WATKINS, Jerry. Digital Cultural Communication: audience and remediation. In: CAMERON, Fiona; KENDERDINE, Sarah (Eds.). Theorizing digital cultural heritage: a critical discourse. Cambridge: MIT Press, 2007, p. 149-164.

SÁ FILHO, Carlos Alberto Cordeiro de. Influência das TIC na dinâmica cultural e política de comunidades. Dissertação (Mestrado), Escola de Engenharia de São Carlos, 2006. Disponível em: 
<http://www.teses.usp.br/teses/disponiveis/18/18142/tde-19122006-175142/publico/SaFilhoCAC InfluenciadasTIC.pdf>. Acesso em: Jun. 2011.

SÁ NETO, Francisco de; GUERRA, Cláudio Lacerda. Programa Patrimônio em Rede. In: WORKSHOP DISPONIBILIZAÇÃO DE ACERVOS HISTÓRICOS, 1. , 18 Set. 2013, São Carlos-SP.

SANTIAGO, Rodrigo Peronti. Memória e patrimônio cultural em ambientes virtuais. Dissertação (Mestrado) - Escola de Engenharia de São Carlos - USP, São Carlos-SP, 2007.

SANTIAGO, Rodrigo Peronti; et al. Patrimônio cultural em ambientes imersivos colaborativos: a experiência do projeto AIVITS. In: CONVENCIÓN CIENTÍFICA DE INGENIARÍA Y ARQUITECTURA, 14., 2-5 Dez. 2008. Havana, Cuba. Anais eletrônicos... Havana: [s.n.], 2008. [online] Disponível em: <http://www.arq.ufmg.br/ eva/art018.pdf>. Acesso em: Jan. 2011.

SANTOS, Rogério José de Almeida. Teoria da Informação. 12 jul. 2005. [online] Disponível em: <http://ainformacao.blogspot.com.br/2005/07/teoria-da-informao.html>. Acesso em: 20 out. 2012.

SANTOS, Christiano Ricardo dos; RÜCKERT, Aldomar Arnaldo. Reduções Jesuíticas Guarani: região turística transfronteiriça. In: CONGRESSO LATINO-AMERICANO DE INVESTIGAÇÃO TURÍSTICA, 5., 3-7 Set. 2012, São Paulo. Anais eletrônicos... São Paulo: [s.n.], 2012. [online] Disponível em: <http://gtci.com.br/congressos/ congresso/2012/pdf/eixo2/Santos_Ruckert.pdf>. Acesso em: Mai. 2013.

SARTINI, Antonio Carlos de Morais. Museus e Comunidade, um Caminho de Mão Dupla. [Palestra] São Carlos-SP: Fundação Pró-Memória, 2014.

SCOTT, Bernard. Second order cybernetics: an historical introduction. Kybernetes, n. 33, v. 9/10, p. 13651378, 2004.

SCHREIBER, Guss et al. Semantic annotation and search of cultural-heritage collections: The MultimediaN ECulture demonstrator. Web Semantics: Science, Services and Agents on theWorldWideWeb, n. 6, p. 243$249,2008$.

SCHWARZ, Bill. Patrimônio histórico e cidadania: a experiência inglesa. In: DEPARTAMENTO DO PATRIMÔNIO HISTÓRICO (Org.). O direito à memória: patrimônio histórico e cidadania. São Paulo: Departamento do Patrimônio Histórico, 1992, p. 67-79.

SCHWEIBENZ, Werner. The "virtual museum": new perspectives for museums to present objects and information using the internet as a knowledge base and communication system. In: INTERNATIONAEN SYMPOSIUMS FÜR INFORMATIONSWISSENSCHAFT, 6., 3-7 Nov. 1998, Praga. ZIMMERMANN, Harald H.; SCHRAMM, Volker (Eds.). Proceedings des... Konstanz: UVK Verlagsgesellschaft, 1998, p. 185-200.

SEGRILLO, Angelo de Oliveira. Rússia e Brasil em Transformação: uma breve história dos partidos russos e brasileiros na democratização política. Rio de Janeiro: 7 Letras, 2005. 
SENATUR. Trinidad: Misión jesuítica guarani. 2012. [vídeo] Disponível em: <http://www.youtube.com/ watch?v=vwAkY4-GTpw>. Acesso em: Abr. 2013.

SENATUR. Misiones, Itapúa y Ñeembucú. 2011b [online]. Disponível em: <http://www.senatur.gov.py/ index.php?option=com_content\&view=article\&id=49\&Itemid=320>. Acesso em: 27 Abr. 2013.

SEPP, Antonio. Introdução. In: SEPP, Antonio. Viagem às Missões Jesuíticas e trabalhos apostólicos. Coleção De Angelis. São Paulo: Itatiaia / Editora da Universidade de São Paulo, 1980, p. 5-15. Escrito em 1697.

SERRA, Geraldo. Pesquisa em arquitetura e urbanismo: guia prático para o trabalho de pesquisadores em pós-graduação. São Paulo: EDUSP. 2006.

SEVCENKO, Nicolau. ... talvez a última grande batalha e ao mesmo tempo a última grande fronteira seja afinal a cultura. Projeto História, São Paulo, v. 10, p. 100-102, dez. 1993.

SILBERMAN, Neil. A. Beyond theme parks and digitized data: what can cultural heritage technologies contribute to the public understanding of the past? Amherst: University of Massachusetts, 2005.

SILVEIRA, Sergio Amadeu da. Redes de relacionamento e sociedade de controle. V!RUS, São Carlos-SP, n.4, dez. 2010. [online] Disponível em: <http://www.nomads.usp.br/virus/virus04/?sec=3 \&item=2\&lang=pt>. Acesso em: Jan. 2011.

SIMON, Mário. Os Sete Povos das Missões: trágica experiência. 4ạ ed. Santo Ângelo: FuRI, 2010.

SNIHUR, Esteban Angel. O universo missioneiro guarani: um território e um patrimônio. Buenos Aires: Golden Company, 2007.

SOSTER, Sandra Schmitt; PRATSCHKE, Anja; SANTOS, Denise Mônaco dos. CROSS: Olhar o outro é refletir sobre si mesmo. In: Nomads.usp (Org.). Territórios híbridos: ações culturais, espaço público e meios digitais. 1ed. São Carlos-SP: IAUUSP, 2013, v. 1, p. 74-79.

SOUZA, José Otávio Catafesto de. A arqueologia na gestão do patrimônio missioneiro no Brasil. In: World Monuments Fund (Org.). Missões Jesuíticas dos Guarani: programa de capacitação para conservação, gestão e desenvolvimento sustentável das Missões Jesuíticas dos Guarani. World Monuments Fund: Brasília, 2004, CD.

STAM, Deirdre C. The informed muse: the implications of "The New Museology" for museum practice. In: CORSANE, Gerard (Ed.). Heritage, museums and galleries: an introductory reader. Nova lorque: Routledge, 2005, p. 54-70.

STEFANO, Roberto Di. The integrated preservation of the Jesuit Missions. In: UNESCO; ICOMOS (Orgs.). The Jesuit missions of the Guarani. Verona: Commercial Bureau, 1997, p. 186-199. 
SUÁREZ, Juan Luís. Hispanic Baroque: a model for the study of cultural complexity in the Atlantic world. South Atlantic Review, n. 72, v. 1, p. 31-47, 2007. [online] Disponível em: <http://hispanicbaroque.ca/ documentation/Suarez-Hispanic_baroque.pdf>. Acesso em: Jan. 2014.

SUÁREZ, Juan Luís et al. Towards a digital geography of Hispanic Baroque art. Literary and Linguistic Computing Advance Access, 2013. [online] Disponível em: <http://www.cultureplex.ca/media/publications/ Digital_Geography.pdf>. Acesso em: Jan. 2014.

SUSTERSIC, Bozidar Darko. The religious imagery and cultural heritage. In: UNESCO; ICOMOS (Orgs.). The Jesuit missions of the Guarani. Verona: Commercial Bureau, 1997, p. 155-185.

SZÁSZ, Barnabás, et al. Cultural Heritage on the Semantic Web: the Museum24 project. s.d. [online] Dísponível em: <https://www.artio.net/downloads/presentations/museum24-project/download>. Acesso em: Nov. 2013.

TAN, Beng-Kiang; RAHAMAN, Hafizur. Virtual heritage: reality and criticism. In: INTERNATIONAL CAAD FUTURES CONFERENCE, 13., 2009, Montreal. TIDAFI, Temy; Dorta, Tomás (Eds.). Proceedings of... Montreal: Les Presses de l'Université de Montréal, 2009, p. 143-156.

TEIXEIRA, Gil Uchôa. As grandes transformações. In: TEIXEIRA, Gil Uchôa (Coord.). Missões: passado presente - futuro. Porto Alegre: Talento, 1990, p. 11-18.

TELERMAN, Jorge. [Sem título] In: MUSEO DE ARTE HISPANOAMERICANO ISAAC FERNÁNDEZ BLANCO (Org.). Misiones Jesuíticas brasileñas. Buenos Aires: Museo de arte hispanoamericano Isaac Fernández Blanco, 2000, p. 13.

THERIN-WEISE, M \& G. Sem título. In: UNESCO. Jesuit Missions of the Guaranis: San Ignacio Mini, Santa Ana, Nuestra Señora de Loreto and Santa Maria Mayor (Argentina), Ruins of Sao Miguel das Missoes (Brazil). Gallery. s.d. [online] Disponível em: <http://whc.unesco.org/pg.cfm?cid=31\&l=en\&id_site=275\& gallery=1\&\&index=1>. Acesso em: 19 ago. 2013.

THOMSON, Garry. The museum environment. Oxford: Butterworth-Heinemann, 1995. 1a ed. 1978.

TOGNON, Marcos. Patrimônio cultural rural paulista: espaço privilegiado para a pesquisa, ensino e turismo. 2008. [online] Disponível em: <http://www.bv.fapesp.br/pt/pesquisa/?q=Patrim\%C3\%B4nio+cultural+rural tpaulista\&index=>. Acesso em: Jan. 2014.

TOSCANO, Wagner. Minerador web: um estudo sobre mecanismos de descoberta de informações na web. Dissertação (Mestrado). Escola Politécnica da Universidade de São Paulo, São Paulo, 2003.

TURISMO Jesús y Trinidad. 2013 [online] Disponível em: <http://www.w1.turismojesusytrinidad.com.py/ explore/trinidaddelparana/>. Acesso em: Mai. 2013.

UNAM. TIC en la educación en Coursera: plataformas y entornos virtuales. 04 Jun. 2013. Disponível em: <http://www.youtube.com/watch?feature=player_embedded\&v=MBBE5gE3Y6U>. Acesso em: Jun. 2013. 
UNESCO. Convention concerning the protection of the world cultural and natural heritage. World Heritage Committee. $17^{\text {a }}$ sessão. Cartagena, Colômbia, 6-11 Dez. 1993. Disponível em: <http://whc.unesco.org/ archive/repcom93.htm\#648>. Acesso em: Abr. 2013.

UNESCO. Jesuit Missions of La Santísima Trinidad de Paraná and Jesús de Tavarangue. 2013a. [online] Disponível em: <http://whc.unesco.org/en/list/648>. Acesso em: Out. 2011.

UNESCO. Jesuit Missions of the Guaranis: San Ignacio Mini, Santa Ana, Nuestra Señora de Loreto and Santa Maria Mayor (Argentina), Ruins of Sao Miguel das Missoes (Brazil). 2013b. [online] Disponível em: <http://whc.unesco.org/en/list/275/>. Acesso em: Abr. 2013.

UNESCO no Brasil. Objetivo Estratégico 5. [online] Disponível em <http://www.unesco.org/pt/brasilia/ communication-and-information/strategic-objective-5-ci/\#c37229>. Acesso em: Fev. 2011.

UNISINOS; IPHAN. Projeto Missões, Computação Gráfica: Uma trajetória de razão e sensibilidade. Núcleo de Computação Gráfica do Centro de Ciências Exatas Tecnológicas da Unisinos em convênio com o Instituto do Patrimônio Histórico e Artístico Nacional - IPHAN 12a SR/RS. São Leopoldo: Unisinos; IPHAN, 1990, CD.

VENTURINI, Sergio. O índio nas Missões. Porto Alegre: Martins Livreiro, 2009.

W3C. Semantic Web. [online] Disponível em: <http://www.w3c.br/Padroes/WebSemantica>. Acesso em: Mai. 2011.

WEIMER, Günter. As reduções jesuíticas. In: WEIMER, Günter. A arquitetura. Porto Alegre: UFRGS, 1999, p. 21-27.

WIENER, Norbert. Cibernética e sociedade: o uso humano dos seres humanos. São Paulo: Cultrix, 1968. 1a ed. 1950, atualizado pelo autor em 1954.

WILDE, Guillermo. Interpretações históricas e atuais da experiência jesuítica. Entrevistadora: Patricia Fachin. Trad. Moisés Sbardelotto. IHU on-line - Revista do Instituto Humanitas Unisinos, n. 348, ano 10, 25 Out. 2010. [online] Disponível em: <http://www.ihuonline.unisinos.br/index.php?option=com_content\&view= article\&id=3603\&secao=348>. Acesso em: Nov. 2013.

WITCOMB, Andrea. The materiality of virtual Technologies: a new approach to thinking about the impact of multimedia in museums. In: In: CAMERON, Fiona; KENDERDINE, Sarah (Eds.). Theorizing digital cultural heritage: a critical discourse. Cambridge: MIT Press, 2007, p. 35-48.

WORLD MONUMENTS FUND (Org.). Missões Jesuíticas dos Guarani: programa de capacitação para conservação, gestão e desenvolvimento sustentável das Missões Jesuíticas dos Guarani. World Monuments Fund: Brasília, 2004.

YUNES, Lucia. O museu e a escola. Texto da apostila do professor. 2011. Disponível em: <http://ebookbrowse.com/cnfcp-museu-escola-lucia-yunes-pdf-d64742449>. Acesso em: Mar. 2013. 
ZAGO, Manrique. Our collective heritage. In: UNESCO; ICOMOS (Orgs.). The jesuit missiones of the Guaranis. Verona: Commercial Bureau, 1997, p. 13. 


\section{LISTA DE FIGURAS}

Figura 1. Tratado de Tordesilhas, mostrando o território sob domínio espanhol e a localização dos chamados Trinta Povos das Missões.

Figura 2.

Regiões onde foram fundadas as primeiras Reduções no Brasil.

Figura 3.

Movimentações de jesuítas e indígenas e de bandeirantes.

Figura 4.

Os Trinta Povos das Missões com suas datas e ordem de fundação.

Figura 5.

Distribuição do território brasileiro com o Tratado de Madri......

Figura 6.

Representação da implantação de uma redução jesuítica.

Figura 7.

"Vista a voo de pássaro de uma missão jesuítica".

Figura 8. Igreja provisória de San Cosme y Damián, exemplo da Fase 2

- já destruída; Campanários de Trinidad e de Santa Rosa.

Figura 9.

Desenho de Lucio Costa da igreja de São Miguel com o pórtico.

Figura 10. Arcos internos que separam a nave central das laterais e torre da igreja de São Miguel em reconstituição virtual.

Figura 11. Figura 11. Igreja de Gesú, em Roma, e reconstituição da Igreja de São Miguel Arcanjo sem o pórtico, no Rio Grande do Sul.

Figura 12. Nossa Senhora da Conceição, São Lourenço e Sino de São Miguel.

Figura 13. 1. Símbolo da Companhia de Jesus em San Ignácio Miní. 2. Trinidad.

3. Sagrado coração em São Miguel.

Figura 14. Santos no Museu das Missões, em São Miguel: 1. São José.

2. Santo Isidro. 3. Nossa Senhora da Conceição..

Figura 15. 
Figura 16.

As Trinta Reduções Jesuíticas nos países em que se localizam atualmente.

84

Figura 17. Localização dos sítios históricos em relação às cidades: São Miguel

Arcanjo - Brasil, Trinidad - Paraguai, e San Ignácio Miní - Argentina.....

Ruínas em meio às matas. De cima para baixo:

Figura 18. 1. São João Batista e 2. São Lourenço Mártir, no Brasil;

e 3. e 4. Santa María Mayor, na Argentina.

Sobreposições das reconstruções hipotéticas das Reduções de São Miguel Arcanjo - Brasil (realizada em 1947 por Lucas Mayerhofer, mas

Figura 19. atualmente sabe-se que alguns aspectos desta reconstrução não estão corretos) e de San Ignácio Miní - Argentina sobre as cidades atuais.

Ruínas em São Miguel Arcanjo - Brasil: 1. Praça, 2. Marcação das

Figura 20. moradias, 3. Cemitério, 4. Igreja, 5. Quinta dos padres, 6. Pátio dos Padres, 7. Pátio das Oficinas, 8. Cotiguaçu.

Ruínas em Santísima Trinidad - Paraguai: 1. Praça, 2. Moradias,

Figura 21. 3. Cemitério, 4. Igreja, 5. Quinta dos padres, 6. Pátio dos Padres e das Oficinas, 12. Campanário, 13. Segunda igreja.

Ruínas San Ignácio Miní - Argentina: 1. Praça, 2. Moradias, 3. Cemitério,

Figura 22. 4. Igreja, 5. Quinta dos padres, 6. Pátio dos Padres, 7. Pátio das Oficinas, 9. Cabildo, 10. Cadeia, 11. Hospital..

Estruturas do sítio histórico de São Miguel: 1. Secretaria Municipal de Turismo; 2. Entrada do sítio histórico; 3. Museu; 4. Antiga casa do zelador, atual IBRAM; 5 . Espaço multimídia na antiga sacristia; 6 . Arquibancadas para o espetáculo noturno; 7. Spots de luz para o espetáculo noturno;

Figura 23. 8. Trailer de comando do espetáculo noturno. No topo à direita, esculturas em madeira policromada em exposição no Museu das Missões.

Estruturas do sítio histórico de Trinidad: 1. Secretaria de Turismo;

2. Entrada do sítio histórico; 3a e 3b. Locais de exposição;

Figura 24.

4. Antiga moradia reformada; 5 . Igreja atual contendo imagens sacras como a mostrada no topo à direita.

struturas do sítio histórico de San Ignácio Miní: 1. Entrada do sítio

Figura 25. histórico; 2. Museu; 3. Totens informativos; 4. Apoio ao visitante.

No topo à direita, coluna em exposição no museu.

Figura 26. 
elementos envolvidos em cada sítio histórico (à esquerda) e as relações entre os três principais sítios históricos (à direita).

Figura 27. Interações entre os agentes envolvidos na preservação, possibilitadas pelo patrimônio

Figura 28. A importância do guia de turismo no sistema de comunicação das Missões Jesuíticas.

Figura 29.

Rotas Jesuíticas incentivadas pelos governos paraguaio e argentino.

Figura 30.

Roteiro Iguassu-Misiones

Figura 31.

Dados das cidades que ainda possuem sítios históricos,

de acordo com Stefano (1997).

Figura 32. Estado de conservação das igrejas de São Miguel - Brasil e San Ignácio

Miní - Argentina antes dos trabalhos de restauro.

Figura 33. Espetáculos noturnos e os trajetos realizados em Trinidad - Paraguai e

San Ignácio Miní - Argentina.

Figura 34. Obras de arte de pedra mantidas na igreja de Trinidad, sujeitas à ação de fatores climáticos.

Figura 35.

Os três sujeitos envolvidos na observação museológica (CURY, 2012)

Figura 36. analisados sob o viés da dependência do observador (MÜLLER, 2007)

Espaços museológicos das Missões visitadas.

Figura 37.

Relações entre os agentes proporcionadas pela inserção de uma plataforma digital no sistema de preservação.

Figura 38.

Reconstituições dos sítios históricos de São Miguel - Brasil (acima), e San Ignácio Miní - Argentina (abaixo)...

Figura 39.

Divulgação online internacional: páginas da UNESCO que divulgam as Missões Jesuíticas inclusas na Lista do Patrimônio Mundial.

Divulgação online brasileira: Acima, página sobre as missões jesuíticas declaradas em nível mundial no site do IPHAN.

Figura 40. Ao centro, site da Secretaria de Turismo da cidade de São Miguel.

Abaixo, site da Rota das Missões. 
Divulgação online paraguaia: Acima, páginas do portal da SENATUR

Figura 41. que contêm informações sobre as Missões Jesuíticas.

Abaixo, portal Ruta Jesuítica.

Figura 42. Divulgação online argentina. Acima, portal Misiones Jesuíticas Guarani.

Abaixo, portal do Ministério do Turismo da Província de Misiones.

Interface da versão teste do sistema web em desenvolvimento intitulado

Figura 43. Memória Virtual: tela de cadastro de bens patrimoniais resumida (acima) e estendida (abaixo) ..................................................................... 186

Figura 44.

Projeto O Hispânico Barroco..................................................................... 188

Figura 45.

Pequena parte da ontologia do projeto O Hispânico Barroco.

Figura 46.

Exemplos de portais que utilizam a Web Semântica como linguagem.........

Figura 47.

Figura 48.

Página inicial do Álbum Fotográfico: imágenes para el recuerdo.

Site Pinhal Digital que reúne o material levantado durante o curso de extensão

\section{LISTA DE TABELAS}

Missões jesuíticas ordenadas por data de fundação, contendo nome dos

Tabela 1. fundadores e atual cidade onde se localizam.......................................... 36

Tabela 2. Órgãos relacionados à preservação das missões jesuíticas.......................... 120 
247 
